\title{
SICKNESS ABSENCE \\ IN BELGIUM, GERMANY (ER) \\ AND THE NETHERLANDS \\ A COMPARATIVE STUDY
}

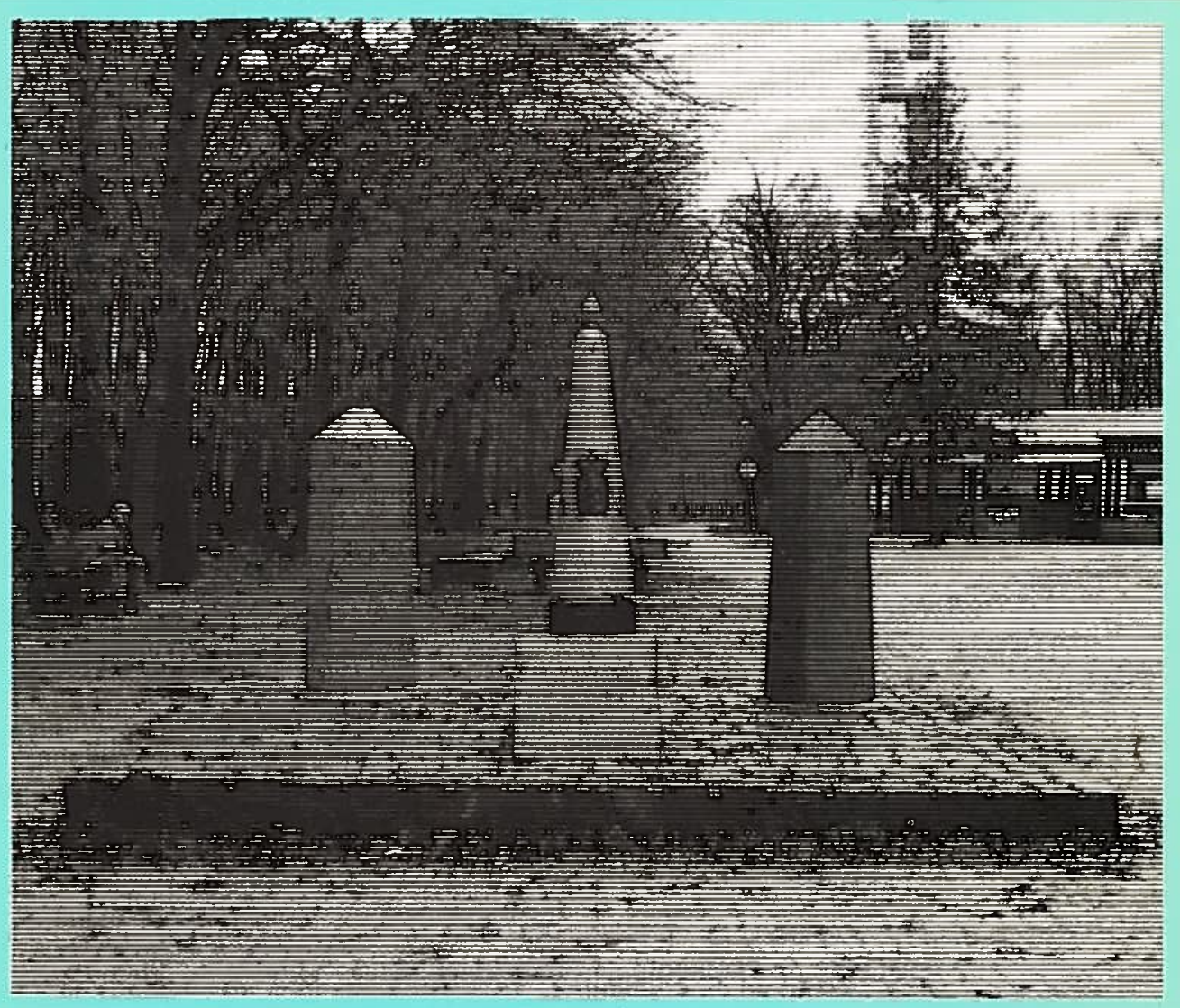

RIENK PRINS 
Sickness absence in Belgium, Germany (FR) and the Netherlands; a comparative study 



\section{STELLINGEN}

behorende bij het proefschrift van Rienk Prins

1. Enterline's constatering dat landen met hoge ziekteverzuimcijfers doorgaans ook lage sterftecijfers hebben is nog steeds actueel.

(P.E. Enterline, Sickness absence in certain western countries, Industrial Medicine and Surgery, p. 738-741, 1964).

2. "Ziek doorwerken" komt in Nederland minder voor dan in de ons omringende landen.

3. Wederinvoering van het onderscheid tussen "risque social" (ziekte, handicap) en "risque professionel" (bedrijfsongeval, beroepsziekte) zal de uitvoeringskosten van de arbeidsongeschiktheidsregelingen doen toenemen alsmede de omvang van juridische tijdschriften.

4. In internationaal onderzoek op het terrein van de sociale zekerheid zijn case-studies onmisbaar om de uitvoeringspraktijk en de latente functies van de regelingen zichtbaar te maken.

5. De instelling van nieuwe werkgroepen rond oude thema's is een excuus om de bestaande kennis niet toe te passen.

6. De uitdrukking "Dutch treat" roept in het angelsaksische taalgebied onjuiste associaties op over het niveau van de sociale zekerheid in Nederland.

7. De hoge dichtheid aan verzekeringsgeneeskundigen in Nederland staat in sterk contrast tot de omvang van de rapportage over hun activiteiten.

8 Op Amerikaanse leest geschoeide bedrijfsalcoholprogramma's zijn niet toepasbaar in Nederlandse bedrijven en instellingen.

(D.A. Bijl \& M.A. Ziekenmeijer, Een valse start is snel gemaakt: bedrijfsalcobolbeleid in de praktijk, $M$ en O 1989, 43, p. 339-353).

9 In het onderzoek van organisatieveranderingen gaat de procesevaluatie vaak ten koste van de vaststelling van effecten.

10. Het feit dat in Nederland de sprookjes met "...en ze leefden nog lang en gelukkig" eindigen bewijst dat van oudsher een hoge levensverwachting van Nederlanders niet als iets uitzonderlijks wordt gezien.

(L. Payer Medicine and Culture, 1989).

11. Terecht is het Middelnederlandse werkwoord "belgen" uit onze woordenschat verdwenen.

Stellingen bij het Proefschrift "Sickness absence in Belgium, Germany (FR) and the Netherlands; a comparative study", Rienk Prins, maart 1990. 



\section{SAMENVATTING}

Bij de discussies over de hoogte en ontwikkeling van het ziekteverzuim in Nederland komen onvermijdelijk vragen aan de orde over de situatie in het buitenland. Nu gaven in het begin van de jaren tachtig bepaalde overzichten en studies aan, dat het ziekteverzuim in Nederland tot de hoogste in Europa moest worden gerekend. Aangezien aan de gebruikte cijfers echter diverse beperkingen kleefden werd door het bestuur van de voormalige Stichting $\mathrm{CCOZ}$ (thans NIA) besloten een verkennende studie te laten verrichten. De probleemstelling van het onderzoek bestond uit twee vragen:

1. Wat zijn de verschillen in het ziekteverzuim van werknemers in België, WestDuitsland en Nederland?

2. Wat zijn hiervan de mogelijke achtergronden?

Het onderzoek is uit drie delen opgebouwd. Teneinde vertrouwd te raken met het thema werden eerst bestaande studies, wettelijke kaders en bestaande statistieken bestudeerd. In het tweede deel zijn de aard en omvang van de internationale verschillen onderzocht, terwijl in het derde deel wordt getracht om inzicht te krijgen in de achtergronden van onze bevindingen.

Hoofdstuk 2 doet verslag van het literatuuronderzoek naar de bronnen, opzet en conclusies van dertien publikaties die tussen 1964 en 1986 over ons thema verschenen. Behalve veel "macroscopische" studies (met geaggregeerde gegevens over werknemers- en verzekerdenpopulaties) werden ook enkele "mesoscopische" onderzoekingen aangetroffen (die gebruik hadden gemaakt van cijfers van vergelijkbare bedrijven uit verscheidene landen). Van diverse studies bleek de methodische basis erg beperkt te zijn, zonder dat hiervan voldoende rekenschap werd gegeven (beperkte vergelijkbaarheid van begrippen, grootheden en populaties). De gepresenteerde cijfers gaven echter meestal wel aan, dat Nederland hoog in de internationale ziekteverzuim-rangorde stond.

In Hoofdstuk 3 wordt de sociale verzekeringscontext van het ziekteverzuim vergeleken. Er blijken tussen de drie landen aanzienlijke verschillen te bestaan in structuur, uitvoering en uitkeringsniveau van de nationale ziektewetten. Opvallend is dat elders een aparte ongevallenverzekering voorkomt, terwijl de loondervingsregeling in geval van ziekte een aanzienlijk eigen risico voor werkgevers kent. Verder doen zich verschillen voor ten aanzien van wachtdagen, niveau en duur van de uitkeringen, en de legitimatie en controle van de arbeidsongeschiktheid. Op deze aspecten blijken de verschillen het grootst te zijn tussen Nederland en België, met respectievelijk de minste en de meeste restrictieve condities.

Ten behoeve van een valide meting en vergelijking van het ziekteverzuim 
wordt in Hoofdstuk 4 gekozen voor een vergelijking op bedrijfsniveau met gebruikmaking van individuele verzuimgegevens. Verzekeringstechnische, conceptuele en data-technische oorzaken van verschillen kunnen aldus zo veel mogelijk worden uitgeschakeld, terwijl doorkruisende populatiekenmerken eveneens onder controle kunnen worden gehouden. Het onderzoeksontwerp is gericht op het uitvoeren van case studies in enkele internationale clusters. Elk cluster bestaat uit drie bedrijven die qua produkt en produktieproces, grootte en ligging (industriegebied - platteland) sterk overeenkomen. Door de "matching" op deze criteria kan hun invloed op internationale verschillen worden uitgeschakeld. Voor het onderzoek konden vier clusters worden samengesteld met in totaal elf bedrijven (daar én Westduitse deelnemer zich terugtrok). De clusters zijn afkomstig uit de chemie (verfindustrie), levensmiddelenindustrie (margarine, diepvries) en metaalproduktenindustrie (blikverpakkingen), en omvatten tijdens onze waarnemingsperiode (1-1-1980 tot 1-1-1982) 11.127 werknemers.

Hoofdstuk 5 geeft een overzicht van de case studies die volgens een identieke opzet in de clusters werden uitgevoerd. In de vergelijking van verzuimpercentages, meldingsfrequenties en gemiddelde duur of duurklassen, blijken de Belgische bedrijven steeds het laagste ziekteverzuim te hebben. Teneinde de invloed van verschillen in leeftijdsopbouw, percentage mannen-vrouwen en soort werk (handarbeiders - beambten) uit te schakelen werden voor beide jaren gestandaardiseerde verzuimcijfers berekend. Hierdoor zijn de verschillen groter en duidelijker geworden. Onder Belgische werknemers is het verzuimniveau het laagst en in drie van de vier clusters komen bij de Nederlandse bedrijven de hoogste percentages en frequenties voor. Twee Westduitse bedrijven bevinden zich tussen beide niveaus en in éen bedrijf ligt het verzuim iets boven het Nederlandse peil.

Een uitgebreide analyse van de structuur en duurzaamheid van de verzuimverschillen is in Hoofdstuk 6 opgenomen. Uit de gestandaardiseerde cijfers blijkt, dat de Nederlandse werknemers zich $70 \%$ meer ziek melden en een $90 \%$ hoger verzuimpercentage hebben dan hun Belgische collega's. De verschillen zijn het grootst voor middellange (1-6 weken) en langdurige (7-52 weken) verzuimgevallen: zowel de meldingen als het volume is twee keer zo hoog als bij het personeel in de Belgische bedrijven. Het Nederlandse ziekteverzuim wordt verder gekenmerkt door relatief veel frequent-verzuimers, weinig "nulverzuimers", een lage werkhervattingssnelheid en twee à drie keer zoveel personen met 1 jaar verzuim ("max.-gevallen") als in de Westduitse, respectievelijk de Belgische populatie.

Uit een trend-analyse van "ziektewetgegevens" wordt duidelijk dat in alle drie de landen sinds 1980 een soortgelijke ontwikkeling waarneembaar is (daling en wellicht stabilisatie). Een vergelijking over de jaren 1983-1987 van gewogen en gestandaardiseerde verzuimcijfers (gebaseerd op uitkeringsgegevens) ondersteunt grotendeels de conclusies uit de case studies. Volgens deze schattingen meldden de Nederlandse verzekerden zich in 1987 nog 50 respectievelijk $100 \%$ vaker ziek dan hun Westduitse en Belgische collega's. De incidentie van gevallen die langer dan zes weken duren ligt nog $80 \%$ boven het gemiddelde buitenlandse niveau. 
Het derde deel van het onderzoek is gericht op het vinden van verklaringen voor de gevonden verschillen. Allereerst worden in Hoofdstuk 7 de conclusies uit ziekteverzuimonderzoekingen in de drie landen vergeleken. Hieruit blijkt onder andere, dat verscheidene factoren en samenhangen een ruime externe geldigheid hebben en in elk land worden aangetroffen (bijvoorbeeld socio-demografische variabelen, werk- en bedrijfsgebonden kenmerken). Aansluitend op de beslissingstheoretische benadering werd een theoretisch referentiekader opgesteld. Hierin zijn gezondheids-, sociale, bedrijfsgebonden en institutionele factoren opgenomen en hun relaties met de ziektedrempel, verzuimdrempel en werkhervattingsdrempel in het individuele verzuimgedrag. Van het geheel van factoren en samenhangen kan slechts een beperkt deel geëxploreerd worden.

In de gekozen onderzoeksstrategie wordt eerst de samenhang van populatieen werkkenmerken met de ziekteverzuimverschillen statistisch verder onderzocht (Hoofdstuk 8). Multivariabele analyse (CANALS) bevestigt grotendeels de overeenkomstige samenhangen en risicogroepen die op basis van de literatuur werden verwacht. Een belangrijk internationaal verschil betreft het verloop. Belgische en Westduitse uitdiensttreders vallen op door hun hoge verzuimfre quentie, Nederlandse uitdiensttreders hebben met name een hoog verzuimpercentage. Een analyse van verzuimverschillen toont aan, dat deze het sterkst samenhangen met de variabele "land". De onderzochte persoons- en werkkenmerken geven met andere woorden geen verklaring voor de internationale verschillen.

In Hoofdstuk 9 vindt een vervolg op de eerdere case studies plaats, zij het op kwalitatieve wijze. De bedrijven in elk cluster zouden op drie terreinen vergeleken worden: personeelsbeleid, werkomstandigheden en bedrijfsgezondheidszorg, en ziekteverzuimbeleid. Aangezien de bereidwilligheid en medewerking internationaal zeer uiteenliepen, moest worden besloten alleen de informatie uit interviews met de betrokken personeelsfunctionaris en bedrijfsarts te vergelijken. Rekening houdend met de beperkte validiteit (sociale wenselijkheid) konden veel overeenkomsten en enkele verschillen worden geconstateerd. In Nederlandse bedrijven lijkt sprake te zijn van een uitvoering van een (breed) sociaal beleid, terwijl de Westduitse en Belgische personeelsafdelingen zich meer economisch georiënteerd - tot personeelsbeheer lijken te beperken. De Nederlandse bedrijfsarts besteedt (per 100 werknemers) minder tijd aan het bedrijf. Een aanzienlijk deel van de beschikbare tijd wordt aan ziektewetcontrole en verzuimbegeleiding besteed. Het eerste is de bedrijfsarts elders verboden, het tweede lijkt weinig te worden toegepast. De ten opzichte van buitenlandse bedrijven minder op discipline gerichte benadering van de personeelsfunctionaris weerspiegelt zich in de ruimere aandacht voor "begeleiding" en "overleg" en in minder nadruk op de toepassing van ontslag (wegens frequent verzuim). Het disciplinaire repertoire lijkt in de Belgische bedrijven het meest uitgebreid te zijn.

In Hoofdstuk 10 worden drie groepen maatschappelijke factoren nader onderzocht, namelijk loondervingsregelingen, mortaliteit en sociaal-culturele aspec- 
ten. De hogere frequentie van kortdurende gevallen in Nederland wordt, behalve met bedrijfsbeleidverschillen, in verband gebracht met de ongecompliceerde ziekmeldings- en legitimatieprocedures. Het hogere langdurige verzuim in Nederland kan voor een belangrijk deel worden toegeschreven aan een grotere ontslagbescherming, een hoog uitkeringsniveau en de relatief soepele toetredingscriteria voor de invaliditeitsverzekering (WAO).

Ten aanzien van het laatste blijken in Nederland jaarlijks gemiddeld twee keer zoveel toekenningen plaats te vinden dan in de ons omringende landen. Aanzienlijk hogere incidenties vallen op bij de jongere en middelbare leeftijdsgroepen en voor twee diagnose-hoofdgroepen: "psyche" (V) en "bewegingsstelsel" (XIII). Verder indiceren de gestandariseerde sterfteciffers, dat Nederlandse intreders in de WAO een relatief gunstige gezondheidstoestand, dan wel een ander mortaliteitspatroon hebben (non-letale klachten en aandoeningen) dan Belgische en Westduitse intreders. Het beeld van de invaliditeit is echter onvolledig: in de omringende landen kunnen ziekte en arbeidsongeschiktheid ook in andere regelingen verborgen zijn (werkloosheids-, gehandicaptenregelingen).

Voor de totale populaties geldt, dat de sterftecijfers en levensverwachting van Nederlanders gunstiger zijn dan die in West-Duitsland en België. Enkele andere indicatoren geven eveneens aan dat het Nederlandse ziektegedrag in bepaalde aspecten iets gunstiger afsteekt ten opzichte van het buitenland (bijvoorbeeld minder artsbezoek, lager medicijngebruik). Wat betreft sociaal-culturele verschillen blijkt in grote lijnen, dat Nederlandse werknemers relatief meer tevreden zijn met hun beloningsniveau en meer gewicht hechten aan niet-materiële werkaspecten (relaties, sfeer, arbeidsomstandigheden). Door de jaren heen blijken Nederlandse werknemers een ondermeer hogere arbeidssatisfactie te hebben dan hun Belgische en Westduitse collega's.

In het elfde hoofdstuk worden de conclusies uit de diverse deelprojecten geïntegreerd en besproken in het licht van het theoretische referentiekader. Vastgesteld wordt, dat verzuimcijfers een slechte ziekte-indicator zijn en dat het relatief hoge Nederlandse ziekteverzuimniveau in eerste instantie niet aan een gemiddeld slechtere gezondheidstoestand kan worden toegeschreven. De ziekmeldingsdrempel is voor Belgische en Westduitse werknemers hoger dan voor Nederlandse personeelsleden (vanwege werkgeversbeleid, administratieve en financiële belemmeringen). Door factoren als inkomensachteruitgang, ontslagrisico, controle-methodiek en hoge invaliditeits-toetredingscriteria ligt elders de werkhervattingsdrempel lager. Uit enkele cross-culturele studies ontstaat het beeld dat de variaties in ziektegedrag, bedrijfsbeleid, loondervingsregelingen, en dergelijke, met culturele verschillen in verband kunnen worden gebracht (bijvoorbeeld normen en waarden met betrekking tot regulering, het vermijden van onzekerheid of zorg voor de zwakkeren en dergelijke). Deze verschillen weerspiegelen zich in bijvoorbeeld vanzelfsprekendheden ten aanzien van medische attestering, disciplinerende of begeleidende benaderingen, de scheiding van behandeling en controle of het nastrevenswaardige niveau van sociale voorzieningen, etcetera. Na een bespreking van de (mogelijke) effecten van een hoog verzuimniveau (bijvoorbeeld ten aanzien van individuele kosten, arbeidssatisfactie, stakingsdagen), worden kort enkele aandachtspunten voor het beleid besproken ( $\mathrm{ZW} / \mathrm{WAO}$-uitvoering, bedrijfsgezondheidszorg, revalidatie). 


\title{
SICKNESS ABSENCE IN BELGIUM, GERMANY (FR) AND THE NETHERLANDS A COMPARATIVE STUDY
}

\author{
PROEFSCHRIFT
}

ter verkrijging van de graad van doctor aan de Rijksuniversiteit Limburg te Maastricht, op gezag van de Rector Magnificus, Prof. Dr. F.I.M. Bonke, volgens het besluit van het College van Dekanen, in het openbaar te verdedigen op donderdag 8 maart 1990 om 16.00 uur

door

Rienk Prins 
Promotores: $\quad$ Prof. Dr. H. Philipsen

Prof. Dr. J.T. Allegro

Beoordelingscommissie: Prof. Dr. J. van der Zee

Prof. Dr. phil. Chr. von Ferber

Prof. Dr. E. Henderickx

Prof. Dr. G.H. Hofstede

Dr. F. Nijhuis

ISBN 90-6365-026-4

Copyright (C) 1990

Behoudens de in of krachtens de Auteurswet 1912 gestelde uitzonderingen mag niets uit deze uitgave verveelvoudigd en/of gemaakt worden door middel van druk, fotografie, microfilm of op welke andere wijze dan ook zonder de voorafgaande schriftelijke toestemming van de auteur. 


\section{CONTENTS}

Preface 9

$\begin{array}{ll}\text { Introduction } & 11\end{array}$

$\begin{array}{lll}\text { PART I PREPARATORY STUDY } & 13\end{array}$

$\begin{array}{lll}\text { Chapt. } 1 & \text { Sickness absence as a cross-national issue } & 15\end{array}$

$\begin{array}{lll}1.1 & \text { Background to the study } & 15\end{array}$

$\begin{array}{ll}1.2 \text { Central problem of the investigation } & 16\end{array}$

$\begin{array}{lll}1.3 & \text { Selection of countries } & 18\end{array}$

1.4 Research strategy and plan of the book 21

1.5 Summary

Chapt. 2 Review of previous comparative studies 23

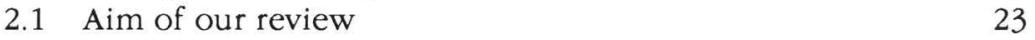

2.2 Macro-statistical comparisons of sickness absence 24

2.3 Meso-statistical comparisons of sickness absence 28

2.4 Methodological aspects of cross-national sickness absence research 29

2.5 Earlier conclusions on international sickness absence $\quad 32$

$\begin{array}{ll}2.6 \text { Summary } & 33\end{array}$

Chapt. 3 Temporary work incapacity: programmes and procedures $\quad 37$

$\begin{array}{ll}3.1 & \text { Characteristics of the social security context } \\ 3.2 & 37\end{array}$

3.2 Sickness benefit programmes 38

3.3 Protection against occupational injuries and diseases $\quad 40$

3.4 Maternity benefit arrangements 41

3.5 Other types of health-related work absence covered 41

3.6 Variations in the social security context of sickness absence 42

3.7 Summary 45

PART II A COMPARATIVE ANALYSIS $\quad 49$

Chapt. 4 Methods and materials in this study $\quad 51$

4.1 Specification of central questions $\quad 51$

4.2 Current data sources on sickness absence 51

4.3 An evaluation in the light of the central problem 53

4.4 The choice for a cross-organizational comparison 55

4.5 Case studies and controlled comparison 56

4.6 Definition and measurement of sickness absence 58

4.7 Acquisition and selection of clusters 59

4.8 Data collection 60

4.9 Summary 62 
$\begin{array}{lll}\text { Chapt. } 5 & \text { Four case studies } & 65\end{array}$

5.1 Description of cases 65

5.2 Comparative strategy and measures applied 66

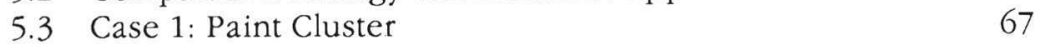

5.3.1 Main characteristics of cluster firms 67

5.3.2 First comparison of sickness absence rates $\quad 69$

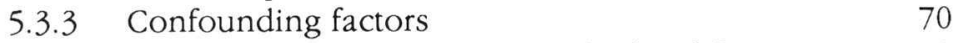

5.3.4 Further conclusions from standardized figures $\quad 72$

$\begin{array}{lll}5.4 & \text { Case 2: Margarine Cluster } & 73\end{array}$

5.4.1 Company characteristics 73

5.4.2 Initial comparison of sickness absence rates 74

5.4.3 Minor effects of confounding factors 75

5.4.4 Findings from standardized sickness absence rates 77

5.5 Case 3: Frozen Food Cluster 77

$\begin{array}{lll}\text { 5.5.1 Main characteristics of this cluster } & 77\end{array}$

5.5.2 Plant-level comparisons of sickness absence $\quad 79$

$\begin{array}{ll}\text { 5.5.3 Confounding factors considered } & 80\end{array}$

5.5.4 A review of findings by standardization 81

5.6 Case 4: Tin Cluster $\quad 82$

$\begin{array}{ll}\text { 5.6.1 Description of cluster firms } & 82\end{array}$

5.6.2 A direct comparison of firm figures 83

5.6.3 Confounding factors examined 85

5.6.4 Standardization and review 86

$\begin{array}{lll}5.7 & \text { Summary } & 87\end{array}$

Chapt. 6 Conclusions from case studies and additional data 89

6.1 An overview of initial case study findings $\quad 89$

6.1.1 Lowest rates in Belgian firms $\quad 89$

6.1.2 Accounting for major population differences $\quad 91$

6.1.3 Highest rates in Dutch firms 93

6.2 A closer look at some cross-national differences 95

$\begin{array}{lll}\text { 6.2.1 Seasonal patterns } & 95\end{array}$

6.2.2 Absence frequency distributions 96

6.2.3 Spell lengths reconsidered 97

6.3 A comparison of trends and recent estimates 102

$\begin{array}{ll}6.4 \text { Discussion } & 105\end{array}$

$\begin{array}{ll}6.5 \text { Summary } & 106\end{array}$

$\begin{array}{lll}\text { PART III INTERPRETATIONS } & 109\end{array}$

Chapt. 7 Theory and methods 111

$\begin{array}{ll}7.1 \text { The purpose of Part III } & 111\end{array}$

7.2 Major theoretical issues and research findings 111

7.2.1 Sickness absence in Belgium: a minor research
issue

7.2.2 Sickness absence in Germany: a temporary topic 112

7.2.3 Sickness absence: a continuous concern in the Netherlands 114

$\begin{array}{lll}7.3 & \text { Cross-national similarities and particularities } & 117\end{array}$ 
7.4 Towards an analytical model of sickness absence $\quad 119$ $\begin{array}{lll}7.4 .1 & \text { Our dependent variable } & 119\end{array}$

7.4.2 Individual sickness absence behaviour $\quad 120$

7.4.3 An integrated model of sickness absence $\quad 122$

7.5 The cultural context of sickness absence 123

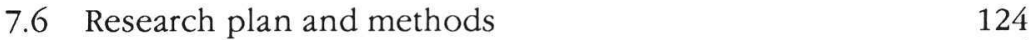

$\begin{array}{lll}7.7 & \text { Summary } & 126\end{array}$

$\begin{array}{lll}\text { Chapt. } 8 & \text { Selected population characteristics and sickness absence } & 127\end{array}$

$\begin{array}{lll}8.1 & \text { Introduction } & 127\end{array}$

$\begin{array}{ll}8.2 & \text { Literature suggests several similarities } \\ 8.3 & 127\end{array}$

8.3 Empirical findings show considerable agreement $\quad 130$

8.4 A multivariate comparison 134

8.4.1 Aim, data and method 135

8.4.2 Common sickness absence factors $\quad 137$

8.5 Multivariate analysis of cross-national differences 139

$\begin{array}{ll}8.6 \text { Discussion } & 141\end{array}$

$\begin{array}{lll}8.7 & \text { Summary } & 142\end{array}$

Chapt. 9 Cross-organizational comparison of sickness absence policies 145

9.1 Introduction 145

9.2 Organizational aspects selected 146

9.3 The collection of data 147

9.4 Personnel policy and occupational health service $\quad 148$

$\begin{array}{ll}\text { 9.4.1 Personnel policy } & 148\end{array}$

9.4.2 Occupational health care and working conditions 149

9.5 Sickness absence policies and the social security context 150

9.5.1 Sickness absence: an organizational priority? 150

9.5.2 Certification and sick reporting 151

9.5.3 Supervision of work incapacity 151

9.5.4 Opinions on major sickness absence causes 152

9.5.5 Comparison of sickness absence policies 153

9.5.6 After exhaustion of sickness benefits.... 154

9.6 Employee turnover and sickness absence 155

$\begin{array}{lll}9.7 & \text { Discussion } & 156\end{array}$

$\begin{array}{lll}9.8 \text { Summary } & 158\end{array}$

$\begin{array}{ll}\text { Chapt. } 10 \text { Societal determinants of sickness absence } & 161\end{array}$

$\begin{array}{ll}10.1 \text { Demarcating the problem } & 161\end{array}$

$\begin{array}{ll}10.2 \text { Sickness benefits programmes reviewed } & 161\end{array}$

$\begin{array}{ll}\text { 10.2.1 Certification and waiting days } & 161\end{array}$

10.2.2 Benefits levels and medical supervision $\quad 163$

10.3 The role of invalidity pension programmes 165

10.3.1 Major dimension of national arrangements $\quad 165$

10.3.2 Invalidity incidence rates compared 167

10.3.3 Administrative and epidemiological aspects
of invalidity

10.3.4 Effects on sickness absence $\quad 174$

\begin{tabular}{l}
10.4 Further labour force selections: unemployment and \\
(early) retirement \\
\hline
\end{tabular} 
10.5 Cross-national differences in health status $\quad 176$

$\begin{array}{ll}10.6 \text { Work-related values and attitudes } & 178\end{array}$

$\begin{array}{ll}10.7 \text { Summary } & 181\end{array}$

Chapt. 11 Conclusions and interpretation $\quad 185$

11.1 Review of research goal and study background 185

11.2 Magnitude and structure of cross-national differences $\quad 185$

11.3 Interpretations of sickness absence differences 187

11.3.1 The role of morbidity 188

11.3.2 Reporting sick 188

11.3.3 Duration determinants depicted 190

11.4 Cross-cultural aspects of sickness absence differences 191

11.5 Consequences and conclusions 193

$\begin{array}{ll}\text { Summary } & 197\end{array}$

$\begin{array}{ll}\text { Samenvatting } & 203\end{array}$

$\begin{array}{ll}\text { Bibliography } & 207\end{array}$

$\begin{array}{ll}\text { List of tables and figures } & 221\end{array}$

$\begin{array}{ll}\text { Curriculum vitae } & 227\end{array}$ 


\section{PREFACE}

This book is about sickness absence in three West European countries. It represents the tip of an iceberg of commitment and contributions given by many persons and institutions. When I started the inquiry (1982) the collection of comparable statistical data was my main concern. As soon as this had been completed the aim of our inquiry would almost have been fulfilled. But remarkable outcomes and a stimulating environment raised further questions: the investigation was expanded and so were our aspirations. I owe a great debt of gratitude to Prof. Dr. Jacques T. Allegro and Prof. Dr. Hans Philipsen for their encouragement, useful discussions and helpful critisism throughout the project.

Cross-national investigation depends to a great extent on the cooperation and assistance given in the countries under study. The extent of the willingness to help a (foreign) researcher was remarkable. I wish to thank the (personnel) managers, occupational physicians and other informants who arranged the supply of statistical data, participated in interviews and who gave valuable feedback on draft reports of case studies. Furthermore several institutes and key informants in the socio-economic field and social security deserve thanks for their advice and - often extended - answers to our questions. I wish to record a special acknowledgment to Mrs. H. de Boeck (Rijksinstituut voor Ziekte- en Invaliditeitsverzekering, Brussels), Mr. U. Rehfeld and Mr. O. Scheitl (Verband Deutscher Rentenversicherungsträger, Frankfurt) and Dr. H. Salowsky (Institut der Deutschen Wirtschaft), who provided valuable data sources, expert knowledge and suggestions. Mr. Gebhard Parigger (Munich) and Dr. Ruud F. Peeters (Universitaire Instelling Antwerpen) gave helpful comments and assistance to the translation (and testing) of questionnaires.

I received a great deal of help and commitment from past and present colleagues. For crucial assistance in the comparison of benefit arrangements, collection of absence data and in fieldwork I am grateful to Saskia Andriessen, Annelies de Graaf and Siert Wolters. A special acknowledgment is due to Jan Besseling who additionally suffered through earlier drafts of this report and provided constructive comments.

I also like to express my gratitude to Huib Nieuwland (Werkgroep Arbeidsvraagstukken \& Welzijn, Leiden) for his help and patience during data analysis, and to Henriëtte Heese and Peter Willemsen for their contributions to assimilating the relevant literature and their continuous alertness regarding relevant cross-national information. In manuscript this book benefitted directly from the suggestions of Bas Vrijhof and from Dr. Stephen J. Searle (The Post 
Office, Birmingham), whose help in converting our writings into more acceptable English was very constructive. We are also particularly thankful to Marleen van Delden and Thérèse van den Berg for the cooperation in the processing of the manuscript with efficiency and good humour.

Last - but certainly not least - I am indebted to my family who shared in the undertaking and whose bilateral composition provided useful suggestions and refreshing relativism.

Maarssenbroek, december 1989 Rienk Prins 


\section{INTRODUCTION}

In the debate on sickness absence it has sometimes been argued that Dutch rates are higher than those in other West Eurepean countries. Indeed, some sources suggested that employees in the Netherlands and Sweden show the highest sickness absence rates compared with employees in other industrialized nations. Not surprisingly, such findings may evoke various reactions. Some authors attributed reported differences to a distinct work ethic, the yearly number of days off, or the level of social security given during sickness. Others, however, blamed the poor quality of sickness absence data applied. This would not allow conclusions on substantial differences, let alone explanations in terms of cultural or social security factors.

The need for an accurate insight led (1982) to a special inquiry into the Dutch position vis-à-vis international levels of sickness absence. Initially the study was nothing more than an orientation to ascertain whether or not our problem was imaginary. The comparison was restricted to sickness absence in greatly similar groups of private sector employees in the Netherlands and both its neigbour countries (observation period: 1980, 1981). The analysis highly confirmed and refined findings from earlier studies. For a more recent observation period (1983-1987) rates adapted and calculated from benefits administrations showed that our conclusions still hold. Generally speaking employees from Dutch firms report markedly more sick and they show substantially more longterm work incapacity (lasting 6-52 weeks) than German and, in particular, Belgian employees.

In the light of these findings our attempt at interpreting these results had to consider a selection of factors operating on different levels of analysis. Most sickness absence investigations regard the effects of personal and organizational factors, which operate within a given national context. After having assessed the weight of some of these factors (socio-demographic variables, job factors, organizational characteristics), our further inquiry has been focussed on macro-level differences. So some aspects of work incapacity arrangements, general health status and health care as well as prevailing value orientations have been compared across our countries under study. Taken together with some related organization-level differences, they showed to be highly relevant for our understanding of the international differences observed in sickness absence rates. 

PART I

PREPARATORY STUDY 



\section{SICKNESS ABSENCE AS A CROSS-NATIONAL ISSUE}

\subsection{Background to the study}

Dutch sickness absence rates doubled within twenty years and showed the highest level in 1978 and 1979. From then on rates have decreased substantially, but after some stabilization from 1988 on they seem to increase again slightly. The trends in this phenomenon are roughly indicated in Table 1.1 showing sickness absence rates in a non-representative sample of over 300 firms. According to the definition commonly used in the Netherlands sickness absence includes here all spells of work incapacity due to illness, accident or confinement, with a maximum duration of 365 calendar days.

Table 1.1 Sickness absence rates in the Netherlands (1964, 1969, 1974, 1979, 1984, 1988).

\begin{tabular}{|c|c|c|c|c|c|c|}
\hline \multirow[t]{2}{*}{ YEAR } & \multicolumn{3}{|c|}{ MALE } & \multicolumn{3}{|c|}{ FEMALE } \\
\hline & $\begin{array}{l}\text { Perc. } \\
\text { calen- } \\
\text { dar } \\
\text { days } \\
\text { lost }\end{array}$ & $\begin{array}{l}\text { Spells } \\
\text { per } \\
\text { person }\end{array}$ & $\begin{array}{l}\text { Dura- } \\
\text { tion } \\
\text { per } \\
\text { spell }\end{array}$ & $\begin{array}{l}\text { Perc. } \\
\text { calen- } \\
\text { dar } \\
\text { days }\end{array}$ & $\begin{array}{l}\text { Spells } \\
\text { per } \\
\text { person }\end{array}$ & $\begin{array}{l}\text { Dura- } \\
\text { tion } \\
\text { per } \\
\text { spell }\end{array}$ \\
\hline 1964 & 5.9 & 1.43 & 15.0 & 5.6 & 2.08 & 9.9 \\
\hline 1969 & 7.7 & 1.75 & 16.2 & 8.1 & 2.52 & 11.8 \\
\hline 1974 & 8.7 & 1.84 & 17.3 & 10.6 & 2.84 & 13.6 \\
\hline 1979 & 9.7 & 1.97 & 17.9 & 12.0 & 3.05 & 14.3 \\
\hline 1984 & 6.9 & 1.72 & 14.7 & 9.2 & 2.70 & 12.4 \\
\hline 1988 & 6.2 & 1.66 & 13.8 & 8.7 & 2.60 & 12.3 \\
\hline
\end{tabular}

Source: Nederlands Instituut voor Preventieve Gezondheidszorg (1989)

Legends: Perc. calendar days lost: Average annual percentage of calendar days lost due to sickness absence per person year.

Spells per Person: Average annual number of spells per person year.

Duration per spell: Average number of calendar days per spell.

In the last two decades the economic and sociopolitical concern with increasing sickness absence rates has given rise to several investigations, almost only published in Dutch, however. These studies contributed to the development of a respectable body of knowledge on sickness absence (and a related subject: disablement) in the Netherlands. Like most social research in other countries they give insight in the influence of socio-demographic, job- and organizational factors, but always under fixed macro-sociological circumstances. Societal factors in the province of benefit regulations or health care as well as prevailing value orientations or industrial relations usually fall beyond the scope of such studies. They basically are considered as a priori elements of the wider context of the phenomenon which, until now, were hardly taken into consideration. 
The lack of cross-societal or cross-national research is particularly felt when sickness absence comes to be a topic in sociopolitical discussions or journalism. As sickness absence was increasing, it was argued that Dutch rates were higher than those in other West European countries. This statement now and then has been illustrated with figures and opinions from international enterprises or data from a few studies in this field. Some experts attribute reported differences to a distinct work ethic, the claim supervision procedures or the level of social security given during sickness. Others blame the poor quality of sickness absence data, that does not allow conclusions on substantial differences or explanations in terms of cultural or social security factors.

Indeed some publications suggest quite unanimously, that employees in the Netherlands and Sweden show the highest sickness absence rates compared to employees in other industrialized countries. According to Vroege (1982) employees in the Netherlands showed the highest sickness absence rates over 1978, compared with France, Federal Republic of Germany(1) and Great Britain. Moreover, studies from Salowsky $(1980,1983)$ and overviews from the Institut der Deutschen Wirtschaft $(1984,1989)$ indicated a second or third rank (among seven industrial nations) for the Dutch a few years ago and an intermediate position in 1988.(2)

The few available international overviews, mainly based on aggregated data from social security administrations, industrial statistics or household interviews, showed some serious limitations and inconsistencies, however. For instance the "sickness absence rate" for the Netherlands over 1978 is $9,2 \%$ in Vroeges study (Vroege, 1982) but Salowsky (1980) estimates for the same year $12,0 \%$. Apparently the definitions and measurements of sickness absence or the observed populations at risk were not identical. It is obvious that such incongruencies may seriously affect any conclusion on the validity of differences or their interpretation (Prins, 1981).

Another limitation of international absence data, is their statistically crude nature. The data presented are merely economic indicators, expressing percentage time lost, without giving any insight into its comprising elements like frequency and severity (duration). Moreover major differences in sociodemographic composition or employment structure of populations usually are not accounted for. Comparative studies or international overviews which are confined to such data may probably show some interesting patterns and tendencies, but leave much room for speculation or hearsay evidence. (3)

\subsection{Central problem of the investigation}

As the paucity and incongruencies of published international sickness absence rates seemed to be a main handicap, the need for an accurate insight in the Dutch position vis-à-vis international levels of sickness absence was felt. To that end representatives from government, social security bodies, employers associations and labor unions, constituting the board of the former CCOZfoundation commissioned a special inquiry into this subject matter. This exploration should take account of methodological weaknesses of previous studies, already indicated to a certain extend in a review of Salowsky's first publication (Prins, 1981). The study should attempt to examine in a systematic 
and comprehensive way the scale and nature of differences in sickness absence rates between the employees in the Netherlands and both its neighbour countries. In case of substantial differences the investigation was to be directed at factors or conditions that might allow for this situation.

So the central questions to be examined in this investigation are:

1 Which differences may be observed between sickness absence rates of workers in Belgium, Germany and the Netherlands?

2 Which factors might account for these differences?

Several aspects of these questions will be considered in the following chapters developing the research plan. However, initially an operational definition of sickness absence should be selected to allow some demarcation of the problem area.

In the Netherlands sickness absence is a heterogeneous concept comprising various types of temporary work incapacity. The definition generally applied reflects a main dimension of Dutch income maintenance regulations, which do not distinguish between sickness, injury or maternity. All these categories of work incapacity are covered by one sickness absence concept and one benefit programme. The temporary character of sickness absence is defined in operational terms too. After one year payment of sickness benefits a worker may be entitled to an invalidity pension. Accordingly, sickness absence includes work incapacity lasting from one to 365 calendar days maximally. Whilst foreign literature has not yet been reviewed regarding the contents and scope of local concepts and definitions, we will primarily have to rely upon Dutch notions. Therefore, our study will focus on health-related absence from work, irrespective of the specific reason, with a maximum duration of one year.

The initial part of this study, examining the first objective, will primarily be explorative and descriptive. As comparatively high rates of sickness absence reported for the Netherlands may be based on inadequate data, an attempt shall be made for a more valid comparison. To that end concepts, benefit arrangements and available statistics will be examined to ensure some common basis for comparisons. In this stage our study is nothing more than an orientation to ascertain whether or not our problem is imaginary. If significant differences in sickness absence can be demonstrated the second part of the investigation will start concentrating on factors that might account for these divergent sickness absence rates.

Particularly this explanatory stage of the research project might contribute to a better insight into sickness absence in the Netherlands. Here we meet a rationale for comparative studies, clearly stated by Mokrzyckis definition (1979, p. 59): "those comparisons that are faced with the specific problems due to the system-boundness of social phenomena". Both the meaning, manifestations and interrelations of a phenomenon are conditioned by a wider context (system), usually operating on national level. Sickness absence is not only determined by factors on a microscopic (person) or mesoscopic level (company), but also by determinants on a macroscopic level, e.g. social security regulations or health services. Factors at this level mostly do not vary within one nation where they are applied to the entire population. At this macroscopic 
level basic elements of the problem are set, conceptually and operationally, but they usually stay out of sight in intranational studies. A cross-national comparison may give a better insight in these macroscopic or societal sickness absence factors, provided lower level factors will adequately be controlled for.

Cross-national studies examining a topic in a number of countries may serve various purposes. In the province of social security and health services regularly articles and reports have been regularly published dealing with some problem and its counterpart in other nations. The objectives of such studies allow a classification into three categories:

1 Evaluative studies, comparing a certain condition in other countries with the domestic situation to give an opinion or evaluation on the latter (Schregle, 1981). Well-known examples of this category are international overviews of income maintenance programmes, suggesting the level of benefits being(un-)favourable in the own country. Review of literature indicates many of these studies have been commissioned or carried out by interested parties (e.g. Eindhovense Fabrikanten Kring, 1979; Seffen, 1980);

2 Policy-oriented cross-national studies may be characterized by their leading interest in "how one's neighbours care coping with similar problems" (Rodgers et al., 1979). These inquiries have generally been focused on the ways (other) nations approach and resolve a common problem. It is assumed that they enlarge knowledge about the ways the domestic situation can be changed. In this respect (European) countries with advanced social security systems seem to be an attractive object for study by administrations with less developed programs (e.g. Copeland, 1977, 1981);

3 Theory-oriented comparative studies examine the influence of certain factors which generally do not vary if the study is limited to the milieu of one nation (Field, 1975). Research in contrasting circumstances may contribute to theory construction and the explanation of a phenomenon, or provide a better understanding of a particular national situation. Literature suggests that this category of comparative studies is found more often in the province of economics or health services than in sociology or social security.

In view of the objectives stated this study may mainly fall under the third type of comparative studies. Although our first question indicates just pure curiosity ("are there any differences"), the second question ("in search of explanations") goes beyond mere description and attempts to examine determinants and underlying processes. Of course, when valid conclusions regarding policy aspects can be drawn, we will not hesitate to do so. This might especially be the case if social security determinants are shown to be relevant to the explanation of our findings.

\subsection{Selection of countries}

The more countries that are involved in a comparison, the more sources of variation have to be dealt with. Hence, it was decided to restrict the number of nations, determining the choice by both theoretical and practical considerations. For illustrative purposes some basic characteristics of the countries selected have been set out in Table 1.2. 
Table 1.2 Selected statistical comparisons, Belgium, Germany, the Netherlands (1979...1988).

\begin{tabular}{|c|c|c|c|}
\hline & B & G & $\mathrm{N}$ \\
\hline Residents population (1000) (1987) & 9834 & 61199 & 14665 \\
\hline Land area $(\mathrm{km} 2)(1987)$ & 30500 & 248700 & 41785 \\
\hline \multicolumn{4}{|l|}{ Percent of population (1986) } \\
\hline Under 15 years & 18.3 & 14.9 & 18.6 \\
\hline $15-64$ years & 67.4 & 70.1 & 68.9 \\
\hline 65 years and over & 14.3 & 15.1 & 12.4 \\
\hline Crude death rate per 1,000 population (1987) & 11.4 & 11.2 & 8.3 \\
\hline Physicians per 10,000 population (1980) & 25 & 23 & 19 \\
\hline \multicolumn{4}{|l|}{ Registered unemployment, average percentage } \\
\hline of working population (1987) & 11.1 & 7.9 & 9.8 \\
\hline Labour force participation rate (1987) & 42.9 & 46.1 & 40.5 \\
\hline Migrant workers per 1000 employees (1983) & 82 & 83 & 41 \\
\hline Unionization rate (as percentage) & 70 & 40 & 30 \\
\hline Gross domestic product per capital (\$) (average 1979-1984) & 9865 & 11600 & 10388 \\
\hline $\begin{array}{l}\text { Productivity levels in manufacturing industry (gros value added } \\
\text { per hour actually worked) (DM) (average 1979-1980) }\end{array}$ & 29.30 & 3556 & 309 \\
\hline Expenditures of social security schemes & 29.50 & 33.34 & 39.84 \\
\hline (as percentage of labour costs, 1988) & 23.7 & 21.0 & 24.1 \\
\hline
\end{tabular}

Sources: Bratt (1982); Bureau voor de statistiek EEG (1984; 1988a; 1988b); Institut der Deutschen Wirtschaft (1985); International Labour Office (1984); Gastarbeiter in Europa (1984).

From a theoretical viewpoint it is clear, that Belgium, Germany and the Netherlands have some fundamental characteristics in common (which, therefore, may be excluded as "explanatory factors"). As indicated by Productivity levels and Gross domestic product per capita (GDP) these countries have developed industrialized economies and a relativily high standard of living. About one quarter of the GDP is spent on social security in each country, which points to an advanced system of social protection with considerable importance for the national economy. Finally, all countries are located in the North-westeuropean hemisphere, with more or less similar climatic and historical-cultural conditions.

Although these countries belong in many socio-economic respects to the same class, on the macroscopic level some major differences can be observed as well. The land area and population size vary considerably between Germany on the one hand, and Belgium and the Netherlands on the other. The first is approximately three times as large as the other two combined. Furthermore, crucial differences in structure and achievements of benefits arrangements are known to exist, which will be considered more thoroughly in Chapter 3. The health status of the populations and their health services seem to differ between (some of) the countries too, as is suggested by remarkably lower death rates and physician rates in the Dutch population. Finally, with respect to characteristics of the work force considerable international variations are shown in registered unemployment, percentage of migrant workers, unionization rates, and days lost due to labour disputes. Despite the important similarities between the countries under study enough differences a priori are known to exist, which make a close comparison of sickness absence rates an interesting operation.

However, not only theoretical but pragmatic considerations as well accounted 
for the choice to compare sickness absence between employees in the Netherlands, Belgium, and Germany. The latter two nations are neighbours, having close economic ties with the Netherlands. They may be seen as "significant others", obvious to compare with our own situation, and being relatively open to satisfy a researcher's curiosity. Moreover, this closeness was thought to facilitate a cross-national comparison. It was expected that quite similar firms might be found willing to provide statistical information, in case national statistics proved to be incomparable. Finally, research conditions like available budget and staff, international contacts originating from other studies, as well as language conditions prevented the researcher extending the study to more countries.

\subsection{Research strategy and plan of the book}

In Section 1.3. a preliminary definition of sickness absence has been selected to delineate the research problem and to set bounderies for review of literature. Although the research plan is mainly determined by the objectives of the study, for an accurate design some more knowledge is required on basic aspects of the subject. On the one hand a review of previous studies comparing sickness absence is necessary to provide an elementary insight in conceptual and methodological aspects of comparing sickness absence rates. On the other hand as sickness absence is predominantly an "output variable" of sickness benefit regulations, basic knowledge of these arrangements is essential. The national social security context may considerably determine the scope and definition of sickness absence, the particular population covered, and the quality or restrictions of available statistics.

We have divided the report into three parts. The preparatory stage of the investigation dealing with available "comparative knowledge" and national social security contexts vis-à-vis sickness absence is reported in PAR'T I PREPARATORY STUDY. Previous cross-national studies on sickness absence are reviewed in Chapter 2, regarding both methodological aspects and substantial conclusions on cross-national differences in sickness absence. The wider context of benefit regulations and administrative procedures in case of sickness is outlined and compared for the three countries in Chapter 3.

PART II A COMPARATIVE ANALYSIS regards the first objective of our study: which differences can be found in sickness absence between the three countries. First of all methodological consequences of the review of literature and the comparison of income maintenance programme are stressed in Chapter 4. This results in a research strategy focussing primarily on a controlled case study approach. The investigation is made on company level, namely by comparing standardized sickness absence rates, directly collected in four international clusters of similar firms. Chapter 5 deals with the similarities and differences over 1980 to 1981 observed in each cluster. Conclusions from our case studies, information and trends in sickness absence, as well as findings from local studies, based on national or sectoral statistics are presented in Chapter 6. Also the results of the comparisons are discussed here to answer the first research question. 
PART III INTERPRETATIONS starts with an elementary theoretical framework and research plan for an exploration of determinants. Chapter 7 considers the theoretical and methodological aspects of this part of the study. The differences observed in our data, and largely supported in less rigid statistics or local studies, might be affected by determinants on different levels of analysis. These have been integrated in an analytical model and research design which guided our further inquiries. As the research plan indicates we focussed our attention primarily on the role of socio-demographic variables, companyrelated factors and effects of income maintenance programmes. Chapter 8 examines on an individual level some sociodemographic differences and their relationship to cross-national sickness absence differences. Chapter 9 reports the results of a close comparison of variables on the organizational level which have been studied by interviews (e.g. policy towards sickness absence, occupational health care, working time arrangements, etc.). Next Chapter 10 deals with potential determinants on a societal level, e.g. in the province of social security regulations (certification procedures, job security during work incapacity, eligibility for invalidity pensions, etc.). As differences in sickness absence may be assumed to be reflecting differences in health status, selected health indicators from the three countries are being compared too. In Chapter 11 an attempt is made to integrate the findings from these chapters and to enlighten the interpretation of cross-national differences in terms of underlying socio-cultural variations.

\subsection{Summary}

Some sources suggest sickness absence rates are high in the Netherlands, compared with other European countries. Available data also suggest remarkable inconsistencies, however, probably due to differences in concepts and measurement. This study attempts to obtain a more valid insight in the scale, nature and determinants of sickness absence in employees in Belgium, Germany and the Netherlands. Preliminarily, sickness absence was defined as temporary health-connected absence from work, irrespective the actual causes (illness, injury, confinement). The investigation comprises three stages. Firstly, we will explore available studies and statistics on the subject as well as its institutional context in each country. In the second part the magnitude and nature of crossnational differences in sickness absence rates will be analysed, whereas in Part III potential backgrounds will be investigated.

PART I PREPARATORY STUDY focusses primarily on a review of previous studies and a comparative overview of benefit regulations, which constitute in each country the legal and institutional context of the phenomenon. An appropriate research plan dealing with the specific problems of cross-national study of our subject will be discussed after this elementary phase of the investigation. 


\section{NOTES}

(1) For sake of readibility we will further use the name Germany.

(2) cf. Table 2.1 in Chapter 2

(3) A historical example of these dangers has been reported by de Groot (1971). The frightening pictures of the mental health situation in the Netherlands, exposed in the press, medical journals, and parliamentary discussions, was shown to be mainly based on the incorrect use of foreign outdated data. 


\section{REVIEW OF PREVIOUS COMPARATIVE STUDIES}

\subsection{Aim of our review}

A first attempt to cast some light on international differences in sickness absence will usually review publications from well-known organizations like EC, ILO, and OECD. Although these sources usually provide an abundance of data on various economic and social indicators, sickness absence or work incapacity are not included and stay out of sight. In our field industrial injuries and occupational diseases are the only subjects for which some international statistics may be found.

However, in the last two decades a number of articles and reports have been published containing statistical information on international differences in sickness absence. These sources range from a simple table, presenting national figures without any background information, to a specialized study dealing with the weaknesses of the statistical basis and interpretation of the data on this subject.

From the available publications those were chosen which contain information over at least two of the countries under study. With regard to the sources and scope of the information used two broad categories of studies can be discerned. The first category presents macro-scopic comparisons of sickness absence based on aggregated data on populations of insured or employed persons. These figures may originate from the sickness benefit administration, employers associations, household surveys, etc. In the second category studies have been focused primarily on a meso-scopic comparison. Usually this means a comparative organizational approach, using absence figures on some more or less similar firms located in different countries. Micro-statistical comparative studies, which would be dealing with differences on the lowest level of analysis - the individual - have not been found.

In order to become acquainted with the research problem and to throw some more light on methodological aspects of cross-national comparison of sickness absence, these studies will be reviewed on four criteria:

a. equivalence of concepts and measures of sickness absence;

b. equivalence of units compared: populations, branches, firms;

c. reliability of basic sources or data used;

d. validity of findings and interpretation.

As the equivalence of concepts and data across nations is a fundamental prerequisite in comparative research, our major concern will be here the discussion of conceptual and statistical aspects of previous studies (a-c). Major conclusions regarding sickness absence rates for our three countries will be summar- 
ized in Table 2.1 and Table 2.2 The suggested explanations of observed differences (d) will be considered in a concise manner. They will be dealt with more thoroughly in the third part of this report.

\subsection{Macro-statistical comparisons of sickness absence}

One of the earliest attempts to compare national sickness absence rates was made by Enterline (1964). For the U.S., Canada and twelve European countries he estimated their "sick absence rates" for 1956 ("percentage of employed persons absent from work on an average day due to illness"). European data originated from national sickness benefit administrations and were adjusted for differences in waiting days, maximum benefit periods and holidays. The Canadian and U.S. figures, however, came from a survey of industries and household interviews, respectively. According to the calculated point prevalence rates sickness absence was considerably lower in North America compared with the European countries. From the three countries under study Germany showed for 1956 the highest rates and Belgium the lowest (cf. Table 2.1).

Although the same definitions were applied (absence due to illness; accidents and maternity leave excluded) and some corrections were made, certain serious limitations of the available data appear to be neglected. Differences in populations covered by benefit schemes, and the restricted validity of the U.S. measurement (household surveys) may have seriously affected the comparability, especially between the two continents. As Taylor (1969) indicated the populations covered by the health surveys and benefit schemes are not identical regarding the inclusion of the long term sick. His adjustment of Enterlines figures reduced the quoted British rate by $30 \%$.

Enterline does not believe that the working populations in Canada and the U.S. are healthier than those in Europe. The higher rates in Europe are suggested to be due to the availability of sickness benefit schemes stimulating absence on the one hand, and remarkably lower unemployment rates in this continent on the other hand.

In a complementary article Enterline (1966) compared sickness absence rates between the U.S.A. and the Netherlands over an 8-year period (1957-1964). Dutch rates came from a sample of firms and industries participating in a voluntary reporting system (cf. Section 1.1) whereas the U.S. figures were obtained from National Health Surveys. Without any adjustments reported a direct comparison was made of monthly sickness absence rates ("percent absent"). The rates for both countries showed almost similar trends (slightly rising in the Netherlands, stable in the U.S.A.) and an identical seasonal pattern was observed as well. However, there was a remarkable difference in severity to be noticed: U.S. rates were constantly just $1 / 2$ or $1 / 3$ of the Dutch figures. As morbidity is assumed to be the same in both countries the author interpreted the observed differences as variations in sickness behaviour, due to distinctive "economic incentives" (i.e. financial consequences of sickness absence and unemployment).

In his article "Some international trends in sickness absence 1950-1968" Taylor (1969) deliberately avoided a direct comparison of national absence rates. 
Differences in methods of measurement and in benefit regulations can not always be adjusted for sufficiently, which may lead to biased estimates. Furthermore, the author states for a valid comparison sickness absence rates should be standardized to age and sex. As these conditions could hardly be fulfilled the author decided to compare trends in sickness absence ("medical incapacity for work") among employed or insured persons in nine countries. Annual rates for frequency and severity of sickness absence were related to a common base line and compared over a 19-year-period (severity: estimated average number of days of incapacity per person). In most of the countries a rising trend was observed, especially in frequency rates. Also, Sweden, Italy, Germany, and the Netherlands showed the steepest rise in severity. The author suggests that the highest increase in sickness absence occurred in countries with more liberal criteria and procedures for entitlement (abolition of medical certifications or waiting days, and benefit payment from the first day).

With updated material and sufficient information on national statistics Taylor (1972) next attempted a direct comparison of sickness absence rates for 1968. Reported data were adjusted according to the definition selected. The sickness absence rates contained the average number of calendar days of absence, due to sickness or injury per person at risk; the maximum duration of an absence being one calendar year. The rising trend in certified sickness absence continued in most countries but was the steepest in the Netherlands for which the highest sickness absence rate was estimated (cf. Table 2.1). The author wonders whether this increase might be due to the changes in 1967 in the sickness benefit arrangements, which no longer required a medical certificate of work incapacity.

Kennedy (1980) presented in his comparative study of European labor relations some international figures on sickness absence. They originated from a study by the Swedish employers association (SAF) and are quoted without any definition or explanation given. According to this poor and deficient information "absenteeism because of claimed sickness" over 1973 in the Netherlands was the third highest of the seven countries studied. (cf. Table 2.1.). The author stated the high rate in this country is "evidently a result of its very liberal sick pay plan". As to both its neighbouring countries Germany showed lower and Belgium the lowest rates.

In 1980 a German report was published that, like Enterlines article in the sixties, would be quoted widely. Salowsky (1980) made a comparison of sickness absence rates of employees (in industry and commerce) in the U.S., Japan and five European industrial nations. For each country major characteristics of benefit regulations and procedures (e.g. certification) were outlined as well as findings or figures from local sickness absence studies. Furthermore impressions were given of typical company policies towards absenteeism in each country and the interest of government, social security bodies, employers organizations and labor unions in the subject.

The phenomenon was studied from an economic rather than a socio-medical viewpoint. The definition of "individual absenteeism" ("individuelle Fehlzeiten") covered absences from work due to illness, injury, rehabilitation 
("Kur"), maternity leave, or personal reasons "on grounds of private circumstances or low job satisfaction" (Salowsky, 1980, p. 8). The sources and up-todate-ness of national sickness absence data varied considerably. National statistics relied on social security data, industrial surveys or reporting systems, doorstep interviews and estimates by local experts. No adjustment was made for divergent measurement methods, benefits arrangements and populations covered. Only differences in yearly number of working days were corrected for. According to these data the European industrial nations showed much higher absence rates (percentage of yearly working time) than the U.S. and Japan (cf. Table 2.1). Dutch rates over 1979 were second highest and about $50 \%$ higher than German estimates. Salowsky attributes the striking "crosscontinental" differences to the great contrasts with Europe regarding social security arrangements (in particular the U.S.) and social- psychological factors (motivation, loyalty to the employing company, particularly relevant for Japan).

A first Dutch attempt to explain rather than merely describe international differences in sickness absence rates was published by Vroege (1982, 1983). Yearly sickness absence rates for Great-Britain, France and Germany were compared with Dutch figures over an 18-year period (1960-1978). The definition, sources, measurement and population at risk of the foreign rates were not revealed: they originate from an EC-bulletin which quoted figures from an unpublished study on working time. Furthermore, effects of crucial changes in Dutch social security legislation in 1967 had been ignored. Dutch sickness absence rates came from the compulsory sickness benefit administration or a voluntary reporting system of firms and industries. A comparison of trends over 18 years showed the highest rates for the Netherlands and Great-Britain. (Figures over 1978 have been set out in Table 2.1). The author attributed the higher rates in the Netherlands to the growth of national productivity in this period. This might have increased the workload and stress in the working population which have not adequately been counterbalanced by a growth of days off in this country.

Salowskys second report (Salowsky, 1983) provided updated rates (for 1981) based on the same mixed measurement as in the first study discussed. All countries showed falling absence rates since 1979. These downward trends are mostly interpreted in these countries in terms of psychological effects of the economic crisis. According to the rates over 1981 the largest decrease had occurred in the Netherlands. This accounted for a shift from the second to the third position in the international sickness absence rank order (cf. Table 2.1). Since this latest study Salowskys international sickness absence rates are yearly updated and, without further comment, published. (e.g. Institut der Deutschen Wirtschaft, 1984, 1989). Conform these sources the Swedish population recently still showed the highest absence rates, whereas the Dutch alternatively came in second or third place. According to most recent figures from this source, West European absence levels converge, indicating just minor differences between German and Dutch industrial employees. 
Finally during our inquiry Pfaff et al. (1986) carried out a valuable investigation of work incapacity in the Federal Republic of Germany (FRG) and selected countries. By collecting social security data and adjusting them to the German "yard stick" a restricted comparison could be made including France, Great Britain, the Netherlands, Sweden and the FRG. The work incapacity measure applied comprised: reported work incapacity due to illness, occupational injury and occupational disease. All short spells, lasting 1-3 days and maternity leave periods were excluded, whereas the maximum spell length being defined as 78 weeks. These work incapacity data, only covering the observation year 1979, further were standardized to sex and age to account for differences in "risk structure" of the working populations.

A close comparison of German and Dutch rates showed some remarkable differences. For the German population only $0.3 \%$ of spells lasted over 52 weeks; but $1.5 \%$ of Dutch work incapacity periods exceeded this limit (by transfer to invalidity pension). In general irrespective age and sex composition in Dutch employees consistently higher frequency rates and longer average spell lengths were noted. Furthermore, the Dutch population showed a more favourable structure as to risk groups compared to the German population, the latter comprising higher proportions of older and female workers. So after standardization for age and sex considerably higher incapacity rates were found among employees in the Netherlands. The overview of these specific measures showed the highest sickness absence percentage in Dutch workers (9.0\%), next came Sweden (6.0\%) and for France, Germany and Great-Britain $5.5 \%, 5.1 \%$ and $3.2 \%$ were calculated, respectively. $(1)$

Table 2.1 Overview of international sickness absence rates from various sources, based on macro-statistics (1956...1988)

\begin{tabular}{|c|c|c|c|c|c|c|c|c|}
\hline Author & Enterline & Taylor & Kennedy & Salowsky & Vroege & $\begin{array}{l}\text { Pfaff } \\
\text { et al. }\end{array}$ & I.D.W. & I.D.W. \\
\hline Obs.Year & 1956 & 1958 & 1973 & 1978 & 1978 & 1979 & 1984 & 1988 \\
\hline Gr. Britain & 4.3 & 15 & 5.1 & - & 8.0 & 3.2 & - & 6.5 \\
\hline FR Germany & 5.7 & 15 & 6.5 & 7.7 & 5.6 & 5.1 & 7.4 & 8.1 \\
\hline France & 4.6 & - & 7.0 & 8.3 & 6.0 & 5.5 & 7.2 & 8.2 \\
\hline The Netherl. & $4.0(5)$ & $21(1)$ & $8.0(2)$ & $12.0(2)$ & $9.2(1)$ & $9.0(1)$ & $7.4(3)$ & $8.5(2)$ \\
\hline Italy & 2.6 & 14 & 8.0 & 10.6 & - & - & 9.0 & 6.9 \\
\hline Sweden & 5.6 & 18 & 10.0 & 13.8 & - & 6.0 & 11.6 & 12.7 \\
\hline Belgium & 3.2 & - & 5.5 & - & - & - & 4.3 & 6.7 \\
\hline USÄ & 1.9 & - & 4.0 & 3.5 & - & - & 3.5 & 3.4 \\
\hline Canada & 1.1 & - & - & - & - & - & - & - \\
\hline Japan & - & - & 3.0 & 2.0 & - & - & 1.8 & 1.6 \\
\hline
\end{tabular}

Table 2.1 summarizes the findings from most previous studies discussed.(2) A comparison of rates for one country (comparison across lines) illustrates the heterogenity of basic material and measures we noted before. Consequently only comparisons within columns are more or less allowed. The rank position of the Netherlands indicated by these sources has been set out in parentheses. The high ranks consistently found in this variety of sources suggest that not only data incongruities account for the (sub-) top position of Dutch employees. 


\subsection{Meso-statistical comparisons of sickness absence}

Cross-national comparisons of sickness absence on a company level are quite rare, at least insofar as they have been published. It seems reasonable however, to assume that more studies have been made, for instance on sickness absence rates in various locations of multinational enterprises. The only "classic" study of this kind we could discover has been published by Thorpe $(1965,1968)$. He made a comparison of sickness absence rates of the European affiliates of the Standard Oil Company, over a 9-year period (19581966). Frequency rates and "non-effective rates" (time lost rates) for sickness and injury (occupational and non-occupational) were obtained from the medical departments. Further information like the populations age structure and sickness benefit programs was available and related to the sickness absence rates. The Dutch affiliate showed to be in the high frequency rate group, whereas the Belgian and German plants were in the lowest group. Regarding the "non-effective rate" the operating unit in the Netherlands was in the highest group; the relative positions of the Belgian and German affiliate were in the middle and lowest group respectively. The author indicated that the rates in the Dutch unit (highest group) and German unit (middle group) might be explained by the way prolonged work incapacity is monitored medically in the Netherlands and by the liberal disability retirement programme in Germany.

A more recent Dutch source containing sickness absence rates from factories in the Netherlands and its neighbouring countries was reported by the employers association in the Eindhoven region (Eindhovense Fabrikanten Kring, 1979). The authors do not sufficiently indicate what is being defined and measured as sickness absence in the locations compared. Notwithstanding, data from several pairs of factories are presented and differentiated as to sex and occupational status. Some of the findings have been adapted and summarized in Table 2.2. They suggest the highest sickness absence rates do constantly occur in Dutch firms, whereas the rates of Belgian and German units are approximately 30-50\% lower. Inspite of the restrictions of the data the report states that social security arrangements and labour attitudes ("work ethic") play a crucial role in the explanation of international differences in sickness absence.

Finally, a cross-national comparison of company sickness absence rates was made by Kramer et al. (1982) in Belgian, German and Dutch factories of a multinational enterprise. The pairs of operating units compared were similar regarding their work type (products), size and composition (development departments were included). Specific sickness absence rates as to sex and occupational status were obtained and, if necessary, adjusted to a common unit of measurement, namely "percentage work days lost". The differences in sickness absence rates between the plants have been set out in an aggregated and summarized way in Table 2.2. It is shown that Belgian and German rates are about $1 / 3$ lower than Dutch rates. In interpreting these findings the researchers indicate work conditions cannot account for the differences observed since the factories were matched to "type of work". Merely it is argued the comparatively high levels of Dutch social security given during short and long term sickness, as well as the favourable job protection regulations are relevant here. They may create a relatively low "threshold" to report sick which facilitates sickness absence behaviour due to escapism, social conflicts, or apathy. 
Table 2.2 International differences in sickness absence based on company figures (1958...1980, adapted)

\begin{tabular}{|c|c|c|c|c|c|c|}
\hline Source & $\begin{array}{l}\text { Observat.- } \\
\text { period }\end{array}$ & $\begin{array}{l}\text { Type of } \\
\text { s.a. rates }\end{array}$ & Units & $\begin{array}{l}\text { Fin } \\
\text { Ind } \\
\mathrm{B}\end{array}$ & G & $\mathrm{N}$ \\
\hline $\begin{array}{l}\text { Thorpe } \\
(1965,1968)\end{array}$ & $1958-1966$ & $\begin{array}{l}\text { freq. rate } \\
\text { non-eff.rate }\end{array}$ & 3 Oil refineries & $\begin{array}{l}72 \\
71\end{array}$ & $\begin{array}{l}63 \\
90\end{array}$ & $\begin{array}{l}100 \\
100\end{array}$ \\
\hline $\begin{array}{l}\text { Eindhovense } \\
\text { Fabrikanten } \\
\text { Kring } \\
\text { (1979) }\end{array}$ & 1974-1978 & $\begin{array}{l}\% \text { work time } \\
\text { lost }\end{array}$ & $\begin{array}{l}2 \text { comparable } \\
\text { locations } \\
\text { Total pop. } \\
\text { male } \\
\text { female } \\
\text { manual } \\
\text { staff } \\
2 \text { comp.locations } \\
\text { Total pop. } \\
\text { male } \\
\text { female } \\
\text { manual } \\
\text { staff }\end{array}$ & $\begin{array}{l}- \\
- \\
- \\
- \\
- \\
- \\
- \\
- \\
- \\
- \\
-\end{array}$ & $\begin{array}{r}58 \\
57 \\
54 \\
60 \\
46 \\
64 \\
64 \\
61 \\
124 \\
60 \\
70\end{array}$ & $\begin{array}{l}100 \\
100 \\
100 \\
100 \\
100 \\
100 \\
100 \\
100 \\
100 \\
100 \\
100\end{array}$ \\
\hline & $1976-1978$ & $\begin{array}{l}\% \text { work time } \\
\text { lost }\end{array}$ & $\begin{array}{l}3 \text { Dutch and } 1 \text { comp. } \\
\text { Belgian location } \\
\text { Total pop. } \\
\text { manual } \\
\text { staff }\end{array}$ & $\begin{array}{l}58 \\
68 \\
53\end{array}$ & $\begin{array}{l}- \\
-\end{array}$ & $\begin{array}{l}100 \\
100 \\
100\end{array}$ \\
\hline & $1975-1978$ & $\begin{array}{l}\% \text { work time } \\
\text { lost }\end{array}$ & $\begin{array}{l}3 \text { Dutch and } 1 \text { comp. } \\
\text { German location } \\
\text { Total pop. }\end{array}$ & - & 71 & 100 \\
\hline & $1975-1978$ & $\begin{array}{l}\% \text { work time } \\
\text { lost }\end{array}$ & $\begin{array}{l}2 \text { locations in } \\
\text { the N. and } \mathrm{B} \text {. } \\
\text { Total pop. } \\
\text { manual } \\
\text { staff }\end{array}$ & $\begin{array}{l}52 \\
50 \\
89\end{array}$ & $\begin{array}{l}- \\
-\end{array}$ & $\begin{array}{l}100 \\
100 \\
100\end{array}$ \\
\hline $\begin{array}{l}\text { Kramer } \\
\text { et al. } \\
(1982)\end{array}$ & 1980 & $\begin{array}{l}\% \text { work days } \\
\text { lost }\end{array}$ & $\begin{array}{l}6 \text { comp. locations } \\
\text { in } B, G \text {, the } N . \\
\text { Total pop. } \\
\text { male } \\
\text { female } \\
\text { manual } \\
\text { staff }\end{array}$ & $\begin{array}{l}67 \\
49 \\
64 \\
57 \\
58\end{array}$ & $\begin{array}{l}68 \\
68 \\
56 \\
64 \\
49\end{array}$ & $\begin{array}{l}100 \\
100 \\
100 \\
100 \\
100\end{array}$ \\
\hline
\end{tabular}

\subsection{Methodological aspects of cross-national sickness absence research}

In the previous section our interest and curiosity was mainly directed by questions as: how did the investigators approach the topic, in which way did they cope with measurement problems, and what conclusions were based on their findings?

Before examining these studies with the criteria set out in the first section, some general observations can be made. Cross-national comparisons of sickness absence are not published regularly. On face value two periods of interest can be discerned (second half of the 1960's and around the end of the 1970 's) in which studies on this subject have been found. Both periods seem to be characterized by considerable increase in absence rates. Another observation to be mentioned is the striking differences between authors regarding 
the attention they pay to conceptual and methodological aspects of the subject. Whereas some inquirers try to start from a sound epidemiological basis, several others accept "given" data from second or third hand sources without reservations. This point will be examined here more thoroughly in evaluating the studies.

The first requirement stated (cf. Section 2.1) concerns the cross-national equivalence of concepts and measurements. Despite striking resemblances of concepts applied in each country, on closer inspection their contents and scope may differ considerably. So a predominant prerequisite to account for is the "construct validity" of the measures to be used in the study. They should be conceptually equivalent, covering the same dimensions of the phenomenon in each population (Pflanz, 1975). This means that one has to ascertain:

- whether absence, absenteeism, sickness absence, or absence due to work incapacity, and other local synonyms cover the same types of absence in each population;

- whether legal aspects and benefit procedures restrict the comparability of definitions and data (e.g. regarding the inclusion of non-certified absence, injury related absence, absence after referral to a temporary or partial invalidity pension);

- whether absences due to industrial disputes, personal days off, holidays or civilian obligations, etc. have been fully excluded from data.(3)

How far have the studies considered met these requirements? Regarding the degree of compliance a distinction into three categories of studies can be made:

1 Publications lacking any (information on) examination of the content and scope of the data compared. Only three studies come into this category, namely Eindhovense Fabrikantenkring (1979), Kennedy (1980), and Vroege (1982). Furthermore, the tables published by the Institut der Deutschen Wirtschaft may be considered here too. Mesoscopic studies are totally absent in this class;

2 Investigations showing some awareness of the problem and applying certain corrections or expressing some doubts. The majority of publications fall into this category: definitions and measures have been compared to a certain degree, and some adaptions were made. Sources of bias controlled for concerned working time (e.g. Enterline, 1964, 1966; Salowsky, 1980, 1983), confinement periods (Enterline), or injuries (Thorpe, 1965, 1986);

3 Studies explicitly dealing with comparability problems. These are quite rare: only Taylor $(1969,1972)$ and Pfaff et al. (1986) systematically accounted for equivalence problems. In 1969 Taylor concluded, after reviewing Enterlines study, that no direct cross-national comparison can be carried out validly. Three years later, however, provided with further information on the countries, an appropriate adjustment of available data could be made. Pfaff et al. (1986) most explicitly dealt with conceptual and measurement problems and had to face many restrictions of the materials. Notwithstanding their investigation mostly meets the standards set out here. On the mesoscopic level the comparison of sickness absence rates by Kramer et al. (1982) also demonstrated a highly concerned attitude, since the researcher interviewed the data suppliers and accounted for several incongruities in measurements. 
It may be concluded that only a few investigations showed sufficient insight in restrictions of "given" data. Several authors fail to define sufficiently what is being measured. Consequently, the need for preparatory study becomes obvious, before analysing any rates from insured populations or personnel from certain firms. Furthermore, the studies in the final category indicate, that comparisons on company level offer better opportunities to check equivalence of measures and to correct for biases.

Until now only one aspect of (any) sickness absence rate was discussed, namely the numerator, referring to absence or work incapacity. The denominator of the fraction, indicating the population at risk, should be equivalent too across categories of employees compared. In this respect several deficiencies could be observed, in particular in almost all macroscopic studies. Populations covered by compulsory benefit regulations may vary between countries, for instance regarding the inclusion of salaried employees or certain economic sectors (e.g. mining, agrarian branches). Sometimes the size of the total population at risk is not exactly known. Besides, the unemployment rate may differentiate considerably between populations of insured and employed persons. More serious problems arise when absence rates are obtained by different methods applied to distinct populations. Reviewing Enterlines article Taylor (1972) illustrated that the British insured population differs considerably from the population of households being interviewed in the U.S. The latter includes persons normally at work in the week before the interview, where as the former includes long-term sick persons too. The same bias yields the comparison of European and U.S. rates in Salowskys studies. Evidently, comparisons on company level are hardly threatened by this problem since the composition of work forces usually are more similar across firms.

The third criterion mentioned was the reliability of basic data-sources. Except studies from Taylor (1972) and Pfaff et al. (1986) on the macroscopic level and the mesoscopic investigation of Kramer et al. (1982) only limited attention has been paid to this aspect of cross-national data. However, as the chain of events leading to the compilation and calculation of sickness absence data is complex, sources of bias may be manifold, e.g.:

- incomplete reporting of short term sickness absences (1-3 days) due to waiting days or distinct certification procedures for wage earners and salaried employees;

- fragmentary inclusion of long term sick persons;

- variation in reporting procedures caused by changes in social security arrangements, which have to be accounted for in longitudinal studies;

- lack of insight in calculation procedures, e.g. regarding size of work force, inclusion of half days sick, weekends, holidays, etc.

From our examination of previous studies it may be concluded that data from company sources allow a better inspection and eventual adjustment of measurement than social security data.

Finally, the validity of findings and interpretation has to be observed. Although conclusions reported already are strongly influenced by the previous aspects, certain questions need further attention. As age, sex and occupational status 
have an "overwhelmingly powerful relationship" with sickness absence these factors should be considered routinely in the analysis (Taylor, 1983). This control for major confounding factors, well-known in epidemiologic research, was only applied in the studies of Thorpe $(1965,1968)$, Eindhovense Fabrikanten Kring (1979), Kramer et al. (1982) and Pfaff et al. (1986). Obviously, company data match this requirement better than macrostatistical data. Consequently, the latter class of studies may show more distortions in international comparisons.

The external validity of the studies, referring to the degree of generalization of findings, may vary considerably too. Mesoscopic studies have a limited scope, as the number of firms from each country is small and representativeness is assumed to be low. In macroscopic studies this aspect may vary with methods used. Whether data from surveys or voluntary reporting systems in industry are representative is generally not known or insufficiently reported. In many studies the interpretation of findings is complicated by two other factors. Firstly, sickness absence has often been measured by a single, merely economic figure, indicating the magnitude of the problem (days lost). Only in very few studies (Thorpe, 1965, 1968; Taylor 1969; Pfaff et al., 1986) data on the frequency of sickness absence were compared additionally. With an exception of Pfaff et al. no studies informed about the average length of spells, which strongly affects the severity of the phenomenon.

Secondly, information on potential determinants of differences in sickness absence, was mostly beyond the scope of the studies. So an interpretation or even explanation of findings, with a few exceptions, was always made in the light of general knowledge or widespread opinions about sickness absence. However, Enterline confirms the hypothesis that national sickness absence rates are negatively associated with unemployment rates. Furthermore, Vroege (1982) casted some light on a positive relationship between time lost due to sickness and yearly working time. Kramer et al. (1982) indicated an inverse relationship between the magnitude of sickness absence and working days lost from industrial disputes.

This review made quite clear that materials generally available to the researcher do not allow a direct comparison or "sweeping conclusions" to be drawn. Generally speaking, without having ensured whether the figures are indicators of equivalent phenomena, occuring in similar populations at risk, conclusions on international differences have a weak statistical basis. Pflanz's statement on "the three C's: completeness, correctness, comparability are essential aspects of the research process" perfectly yields for cross-national sickness absence research (Pflanz, 1975, p. 66). In this respect the insights from this examination may be of limited value for questions about current international sickness absence. But in the development of our own research design they are quite useful (cf. Chapter 4).

\subsection{Earlier conclusions on international sickness absence}

Despite the methodological weaknesses discussed, our curiosity regarding the Dutch position vis-à-vis sickness absence needs some satisfaction. Briefly we will indicate the conclusions suggested in the literature reviewed (cf. Table 2.1 and Table 2.2). 
A first impression from these studies regards the position of the U.S.A. and Japan compared to European nations. Various sources indicated the percentage of days lost due to sickness is 2-3 times higher in West European countries compared to the U.S.A. and Japan. Sickness absence rates reported for the former nations are extremely low.(4) The absence of an advanced social security system, and relatively little job protection (U.S.A.), as well as high degree of loyalty to the company (Japan) are said to account for this phenomenon mainly. But also the differences in recording and reporting procedures should be taken into account (Prins, 1981; Pfaff et al., 1986).

Within West Europe, according to the studies from the 1960's, Dutch employees take a middle or high position in international sickness absence ranks. More recent inquiries also quite unanimously suggest a relatively high level for the Netherlands. However, some sources suggest in the mid eighties Dutch rates may have approached the German level more and more. But the investigations on company level at the end of the 1970's consistently showed the highest absence rates for Dutch firms. In more or less comparable firms in Belgium and Germany absence levels were about $40 \%$ lower. Sex-specific absence rates indicated similar differences.

The authors attribute these differences between European nations to several factors and conditions. Generally no one believes that differences in health status of the populations compared will cause these divergencies. Mostly economic incentives, related to unemployment rates or level of cash sickness benefits are stated to interpret the findings. Furthermore, administrative and supervisory procedures are supposed to play a role. E.g. Taylor (1972) wonders whether the relatively high levels of sickness absence in Sweden and the Netherlands might be due to a lack of certification or medical monotoring of sick persons. Finally, a totally different explanation was given by Vroege (1982), indicating the lack of days off (holidays, etc.) account for the relatively high sickness absence rates for the Netherlands and the United Kingdom.

It may be concluded, that methodological aspects restrict the validity of many of these interpretations. Nothwithstanding, several interesting clues were given, which will be subject to consideration in the third part of our study. One final example of an intriguing aspect, already observed by Enterline in 1964, may already be mentioned: countries with the highest mortality rates also have the lowest absence rates.

\subsection{Summary}

Previous studies comparing various kinds of absence rates across nations showed a relatively high level of sickness absence in persons employed in the Netherlands. The 13 publications examined, covering a period of over 20 years, fall into two categories, namely macroscopic studies, based on aggregated data from entire populations of employed persons or insured; and mesoscopic studies, applying data from a limited number of comparable firms. However in most studies several methodological weaknesses of data became apparent. Some only cite other sources or publications without further data collections or -scrutiny. But also in studies using original data different concepts and measures, dissimilar populations, data incongruities and the restricted validity 
of interpretations seem to be major pitfalls. From the two categories discerned the mesoscopic studies showed comparatively the least methodological weaknesses, their external validity (e.g. representativeness) being restricted, however.

Disregarding these limitations the majority of studies reviewed indicated that Dutch sickness rates are consistently in the upper region of the international sickness absence rank. The most recent investigation, optimally making allowance for methodological restrictions, showed over 1979 about 60\% more sickness absence days in Dutch insured compared to a similar German population (Pfaff et al., 1986). 


\section{NOTES}

(1) An additional comparison, based on data from household surveys and including Japan and the USA showed low rates for these countries, which were similar to those presented by Salowsky (cf. Table 2.1)

(2) If necessary original data were transformed to percentages.

(3) In particular household survey based statistics (USA) and firm surveys (Italy) showed these types of biases. The extreme position of Sweden in Salowsky's overviews and in figures from the Institut der Deutschen Wirtschaft does probably also originate from the inclusion of these categories of non-medical absence types (Prins, 1981).

(4) These remarkable low rates have been supported by a study by Pascal and Maguire (1980), comparing two groups of firms in Japan and the United States. 



\section{TEMPORARY WORK INCAPACITY: PROGRAMMES AND PROCEDURES}

\subsection{Characteristics of the social security context}

As the cross-national equivalence of concepts and measurements is a major condition for valid comparisons our study will firstly have to focus on relevant social security programmes in the three countries. A basic description of income replacement programmes may not only give an important insight in the wider context of sickness absence in each country (e.g. procedures for entitlement, individual financial consequences). In particular it is also expected to serve as a basis for comparisons of the content and scope of local sickness absence definitions, methods of measurement, incongruities in rates based on social security statistics, etc. Finally a close comparison of these regulations may have a heuristic function too: it may furnish hypotheses on potential factors in the field of social security that might account for international differences in sickness absence rates.

For the purpose of this study the comparison has been restricted to temporary work incapacity. Conforming to the extensive Dutch definition of sickness absence the regulations for three types of work incapacity are covered primarily, namely illness, injuries (occupational and non-occupational) and confinement. A further restriction regards the populations covered: as indicated in the first chapter only arrangements for workers in the private sector will be described.

For the description of these arrangements three features will be considered in particular, since they directly affect national concepts and data:

- definitions of temporary work incapacity applied;

- eligibility criteria and procedures: waiting days, certification, supervision;

- level and duration of benefits payment.

In the interpretative section of this chapter (Section 3.6) the three countries will be compared on these elements of their social security context.

The descriptions are mainly based on two sources. On the one hand basic information was found in publications from governmental bodies, social security institutions, local experts or international organizations (EC, ISSA). Further knowledge was furnished by a few comparative studies (Van Steenberge, 1970, 1986; Copeland, 1977) or extensive international overviews (Commissie van de Europese Gemeenschappen, 1982, 1986; U.S. Department of Health and Human Services, 1984, 1986, 1988). Finally, incidental interviews with local researchers or social security officers played an important role: they provided supplementary or explanatory "inside information", without which one would never become sufficiently acquainted with foreign reality, when time is limited.(1) 


\subsection{Sickness benefit programmes}

In the Belgian system the concept of work incapacity is the same for temporary or "primary" work incapacity (lasting one year maximally) as for permanent incapacity or invalidity. The workers earning capacity must have dropped by two-thirds or more under that which a healthy person could earn (with the same age, a similar training, and the same profession). The work incapacity has to be caused by (non-occupational) physical or mental infirmities (Maroy, 1989). In case of work-related work incapacity separate schemes for occupational injuries and diseases are applied.

This compulsory sickness benefit programme provides an income replacement of $60 \%$ of gross earnings, which equals about $80 \%$ of net wages.(2) Before payment of benefits the employer is statutorily obliged to continue payment of normal earnings during an initial period of sickness. For wage earners ("Arbeiders") the employer pays $100 \%$ of earnings for first seven days and supplements benefits during 23 additional days up to $100 \%$ of earnings. (3) Salaried employees ("Bedienden") receive 100\% payment of earnings for up to first 30 days of sickness. One waiting day is imposed but the regulations provide retrospective payment after two weeks of work incapacity. After 30 days of sickness both occupational status groups are entitled to sickness benefits payment for the remainder of the first year of illness.

The compulsory sickness and invalidity programmes is administered by a great number of private mutual benefit societies ("Mutualiteiten") with local agencies paying benefits and medical costs. An unknown number of firms provide additional voluntary arrangements or funds, financed by the employer, labour unions or both. They may pay a supplement to benefits in cases of longer lasting sickness, e.g. among senior workers, union members, etc. If after exhaustion of sickness benefits (one year) work capacity is still reduced by $662 / 3 \%$ or more, the worker may be transfered to the invalidity pension. This program has fairly identical insurance requirements but a lower level of benefits (cf. Section 10.3).

The worker who falls ill and considers himself unable to work has to follow certain procedures to ensure payment of wage and benefits. Under the Belgian system the employer has to be informed about the employees work incapacity within 24 hours. Furthermore, a medical certificate issued by the workers physician, must be sent to the local sick funds agency within two days after the onset of work incapacity. This certificate informs about the diagnosis of the illness, the date of work resumption and restrictions on activity. Most employers legitimately require a certificate (duplicate), which does not contain the medical details. Surveillance and medical control of work incapacity may both be commissioned by the employer, and take place on behalf of the sick funds. During the period of continued wage payment the employer may demand a (counter) medical examination, for instance by a general practitioner of his choice, or a physician of a private medical control bureau. Physicians employed by the sick funds may make a medical examination at the onset of work incapacity too, but generally they will concentrate their control of claims on incapacity which have exceeded the period of wage payment. 
The German compulsory programme to protect workers in case of sickness shows several similarities with the previous system. It only provides benefits in case of sickness. Work incapacity has to be medically certified, payment of full wages is continued at the onset of sickness, and legitimation procedures differentiate between wage earners and salaried employees. Finally, the administration of the sickness benefits programme is as manifold as in Belgium. Over 1300 sick funds ("Krankenkassen") are in operation, organized by locality, by enterprises or by occupation (e.g. self-employed).

In the German system sickness is defined by physical or mental disorders which imply the need for medical treatment, or work incapacity vis-à-vis the present occupation. Whether a spell of work incapacity due to illness is existing is to be assessed by the treating physician who, as in the Belgian system, has an evaluative and certifying task. To claim benefits and wage payment manual workers ("Arbeiter") have to forward a medical certificate on the first day of sickness; for non-manual workers ("Angestellten") certification is obligatory from the fourth day of work incapacity. To promote equal treatment in many firms procedures have been harmonized towards the more liberal legitimation policy. The medical certificate informs the employer and sickness fund about the work incapacity and likely duration. Moreover the medical officials of the fund obtain details regarding diagnosis or special circumstances (e.g. need for rehabilitation).

Supervision and control of work incapacity due to illness is not executed by the medical staff of the sick fund itself, but on request of the fund by physicians from an independent agency ("Vertrauensärztliche Dienst"). Control to eliminate any reasonable doubts regarding work incapacity takes, however, a second position in the duties of this service (Bauer, 1981). A major change in benefits legislation (1970) emphasized as first task to ensure a successful recovery, e.g. by indicating to treating physicians the need for rehabilitation. Since 1983 the employer has received more rights to request a medical examination in case of "founded doubts" about work incapacity (Brill, 1984).

German sickness benefit arrangements provide a sick pay equal to $80 \%$ of gross lost earnings (up to a maximum) which equals normal net wages for most wage earners. It is estimated this holds for about $80 \%$ of German employees.(4) For those salaried employees and wage earners in high wage groups who might experience a loss of income, employers often provide supplementary arrangements (Seffen, 1980). Since 1969 no waiting days are imposed but benefits become payable after a six week period of full wage payment.(5) The duration of temporary work incapacity due to sickness may vary from case to case, depending on the likelihood of medical improvement or successful completion of rehabilitation. The maximum period of benefit payment for a disease or disorder is 78 weeks within a three-year period.

Dutch income replacement programmes for work incapacity differ in several respects from the systems previously considered. Since 1967 the "causality principle" has been abandoned in social security in the Netherlands: no distinction is made anymore between work-connected (occupational, injury and disease) and non work-connected incapacity (illness), neither in entitlement criteria, nor in level and duration of benefits payment. Both types of risks are covered by two schemes: initially the programme for temporary incapacity 
"Sickness Benefits Act" ("Ziektewet") and, after exhaustion of sickness benefits (maximally 52 weeks), entitlement to an invalidity pension usually follows. Furthermore impairment is also covered by these sickness benefits arrangements.

Under the Dutch programme work incapacity refers to the incapacity to do the work normally done before onset of illness or injury. Contrary to the Belgian and Germany situation no medical certification of work incapacity is required. The worker who falls ill must immediately report his work incapacity to his employer, who subsequently informs the sickness benefits agency. The absence of legitimation procedures at the onset of work incapacity in historically based on a separation of treatment and certification tasks. The Dutch assocation of general practitioners has always refused to legitimate work incapacity, for they fear this task might damage the doctor-patient relationship. Alternatively, evidence on incapacity is not ensured at the very beginning but during the sickness period. Procedures comprise surveillance by lay inspectors, generally visiting (a sample of) the sick on the first, second or third day of illness (Poelstra et al., 1985). Subsequently, if work incapacity is prolonged examinations are made by social security doctors employed by or contracted to the funds.

The sickness benefit programme provides an income replacement of $70 \%$ of daily wage, payable after two waiting days. In almost all economic sectors however, collective labour agreements arranged abolition of the waiting period and an increase of benefits equal to $100 \%$ of earnings with a fixed maximum.(๑) Sickness benefits arrangements are administered by 26 occupational associations. These are organised on an industry base and administer several social security schemes for their members (employers). However, about $20 \%$ of the insured are employed by firms who are not a member of the association of their branche. These employers operate a similar income maintenance regulation on their own account. In these cases medical control of work incapacity may be executed by the plant occupational physician, an insurance physician, or a general practitioner, contracted to the employer.

\subsection{Protection against occupational injuries and diseases}

In contrast to the Dutch situation both other countries provide separate income replacement for work-related health risks. Every employer has to be affiliated to a fund, which provides benefits, rehabilitation facilities, etc. In case of temporary work incapacity due to an occupational injury the Belgian worker is entitled to cash benefits which amount to $90 \%$ of normal (net) wages. However, the employer continues payment of full wages for the first 30 days (both for wage earners and salaried employees). Work incapacity is considered as a loss of earning capacity compared with the situation before the injury (Van Steenberge, 1986). The injury and work incapacity should be notified to the insurance company within ten days. Furthermore, procedures prescribe a medical attest of a general practitioner, occupational physician or specialist to authorize the work incapacity. The injury benefit programme, being entirely financed by the employers, is administered by various private insurance companies or mutual associations. Payment of temporary work incapacity benefit continues until recovery or establishment of permanent partial or total disability. 
The Belgian situation is remarkable regarding the position of the treating physician who may be contracted to the insurance company. Besides, Belgium is the only European country with a separate income maintenance programme regarding occupational diseases, also providing a 90\% wage-benefits ratio.

It is obvious that in Belgian regulations the two types of health risk under consideration are not compensated equally. In case of work incapacity due to an occupational injury the income replacement rate is much more favourable (90\%) than in the event of illness ( $80 \%$ of net earnings).

In the German system every employer is compulsorily affiliated to the accident insurance association of his industrial sector ("Berufsgenossenschaft"). These funds provide cash and medical benefits in case of work-connected injuries, commuting accidents (while travelling to and from place of employment) and occupational diseases. Contributions are related to the risk levels of industry and are paid only by employers. The main criterion for work incapacity is loss of earnings regarding general labor market conditions. Benefits for temporary work incapacity are identical to those under the scheme for illness. For the first six weeks the employer statutorily pays normal wages; subsequently the industrial association provides benefits which equal sickness benefits ( $80 \%$ of earnings). German procedures require the worker to consult a specialized physician for medical treatment, assessment of work incapacity, and for referral to rehabilitation measures. Finally, it may be remembered that Dutch work incapacity regulations do not differentiate between illness, injury or occupational disease.

\subsection{Maternity benefit arrangements}

In all the countries under study maternity and confinement provide a statutory right to a period of paid leave, partly or totally covered by the sickness benefits program. In Belgian law the employer is required to provide $100 \%$ of normal earnings for seven days (wage earners) or 30 days (salaried employees). Next, benefits equal to $79.5 \%$ of earnings are provided. The payment of wage and benefits covers the maternity leave period of six weeks before and eight weeks after confinement. German regulations provide normal sickness benefits six weeks before the expected date of confinement and eight weeks after confinement (statutory maternity leave). During this period benefits compensate $100 \%$ of earnings. The Dutch sickness benefit program includes maternity benefits as well. From six weeks before the expected date until eight weeks after confinement benefits are paid covering $100 \%$ of earnings.(7)

\subsection{Other types of health-related work absence covered}

In addition to these common reasons for temporary work incapacity, in Germany more types of health-related absence from work may be observed. Within the scope of this study the so-called "Kur" and "Heilverfahren" seem to be relevant, since they are formally equivalent to work incapacity due to illness (Seffen, 1980). These prevention-oriented rehabilitative measures, often applied in specialized clinics, may be prescribed by the administrations of the traditional three health-connected benefit schemes (sickness, injury, invalidity- 
old age). Furthermore, under certain conditions maternity leave may be extended to six months after confinement with entitlement to (reduced) sickness benefits. Finally, sick funds provide paid leave up to five days a year for a sick child which requires care. As this latter type of absence does not refer to the personal health situation of the worker, this category may safely be excluded from further study here.

\subsection{Variations in the social security context of sickness absence}

The investigation suggests considerable differences in structure, administration and benefits from relevant regulations in the three countries under study. A Dutch worker who falls ill or becomes victim of an injury finds himself in a social security context which is quite different from the situation for his collegues in Belgium or in Germany. Legal, administrative and social aspects of work incapacity are shown to vary in several respects (cf. Table 3).

Table 3 Major dimensions of sickness benefit programmes in Belgium, Germany and the Netherlands

\begin{tabular}{|c|c|c|c|}
\hline Dimensions & Belgium & Germany & the Netherlands \\
\hline $\begin{array}{l}\text { legitimation at onset } \\
\text { of work incapacity }\end{array}$ & $\begin{array}{l}\text { certificate required } \\
\text { on the first day }\end{array}$ & $\begin{array}{l}\text { certificate required } \\
\text { on first (wage earners) } \\
\text { or after third day } \\
\text { (salaried employees) }\end{array}$ & no certificate required \\
\hline waiting days & $\begin{array}{l}\text { one (payable after } \\
\text { two weeks of work } \\
\text { incapacity) }\end{array}$ & none & $\begin{array}{l}\text { statutory two, but mostly } \\
\text { suspended in collective } \\
\text { labour agreements }\end{array}$ \\
\hline $\begin{array}{l}\text { level of sickness } \\
\text { benefits }\end{array}$ & $\begin{array}{l}60 \% \text { of gross earnings } \\
\text { (with maximum) }\end{array}$ & $\begin{array}{l}80 \% \text { of gross earnings } \\
\text { (with maximum) }\end{array}$ & $\begin{array}{l}70 \% \text { of gross earnings } \\
\text { (with maximum) but } \\
\text { collective labour } \\
\text { agreements provide } 100 \%\end{array}$ \\
\hline benefits payment & $\begin{array}{l}\text { after continuation of } \\
\text { wage payment during } \\
2 \text { weeks (wage earner) } \\
\text { or } 4 \text { weeks (salaried } \\
\text { employees) }\end{array}$ & $\begin{array}{l}\text { after } 6 \text { weeks wage } \\
\text { payment by employer }\end{array}$ & $\begin{array}{l}\text { formally after waiting } \\
\text { days }\end{array}$ \\
\hline $\begin{array}{l}\text { surveillance of work } \\
\text { incapacitated }\end{array}$ & $\begin{array}{l}\text { on behalf of employer } \\
\text { by general physician, } \\
\text { specialized agency or } \\
\text { insurance company; } \\
\text { on behalf of sick fund: } \\
\text { insurance doctor }\end{array}$ & $\begin{array}{l}\text { on request of sick } \\
\text { fund by insurance } \\
\text { doctor of independent } \\
\text { agency }\end{array}$ & $\begin{array}{l}\text { lay inspector and } \\
\text { insurance doctor of } \\
\text { occupational } \\
\text { associations }\end{array}$ \\
\hline $\begin{array}{l}\text { maximum duration of } \\
\text { benefits payment }\end{array}$ & (remainder of) 52 weeks & $\begin{array}{l}78 \text { weeks within three } \\
\text { years }\end{array}$ & 52 weeks \\
\hline
\end{tabular}

In Belgium and Germany insurance against income loss and costs of health care are covered in one programme. In the Netherlands however, sickness benefits arrangements are related to the disablement benefits programme. Also striking administrative differences occur regarding the absence of a specific occupational insurance in the Netherlands, or the opportunity for private bodies 
and insurance companies to administer benefit programmes in Belgium. In both other countries public bodies controlled by representatives of employers and employees are mainly responsible for the administration. Another sociologically remarkable feature may be observed in the distinct position of wage earners ("blue collar") and salaried employees ("white collar") in the Belgian and German arrangements, Since a few decades this social divison is completely lacking in the social security arrangements in the Netherlands. Finally, literature and interviews suggested that all systems have some problems in common, like inaccurate instruments for control of social security expenditures, complex and diffuse administrative procedures, as well as unfavorable demographic prognoses (ageing populations).

For our purpose in comparing sickness absence rates three aspects of national arrangements are particularly relevant, namely the definitions of work incapacity applied, criteria and procedures for entitlement, and benefits paid (cf. Section 3.1). As Van Steenberge $(1970,1986)$ already demonstrated precise definitions of work incapacity are lacking in all these sickness benefits regulations. Only in the Belgian case is a formal yardstick given, namely a reduction of earning capacity by at least $66.7 \%$. The German and Dutch systems refer to the need for medical treatment or incapacity for the claimant's own job. In the case of occupational injury only minor differences in the definitions between the German and Belgium regulations have been observed (Van Steenberge, 1970). In particular in Belgium and Germany the lack of clarity in definitions of illness and work incapacity is the subject of extensive publications and jurisprudence.

In spite of these common formal-conceptual ambiguities the Dutch definition clearly deviates in one respect. Comparing sickness benefit regulations in several countries, Pfaff et al. (1986) concluded a "subjective" concept of illness and work incapacity is applied in the Netherlands, since primarily the employee decides whether to report ill or not. In the Belgian, German and many other systems a more restrictive concept is used. In these countries medical examination and certification is obligatory, indicating an objective concept of work incapacity, since illness and perceived loss of work capacity is only accepted if diagnostically confirmed. It is obvious that, at least at the onset of work incapacity, the Dutch definition has the widest scope and can be more easily satisfied than in other countries, as only a telephone call to the employer may start a period of sickness absence.

The previous aspect already points to criteria and procedures applied to legitimate and regulate entitlement for sick pay or sickness benefits. In addition to the observation of Pfaff et al. (1986) some other conclusions can be drawn. Although both systems require medical certification Belgian procedures are more rigid than those for German workers. In order to prevent unnecessary consultations and sickness absence the costs of medical consultations (to receive treatment and a certificate) are not fully reimbursed to the Belgian worker ("Remgeld"). Furthermore, for Belgian employees certification is obligatory on the first day, whereas in Germany a liberal trend was observed (certification after three days of work incapacity).

Another device to overcome weaknesses of the system and its clients is the ap- 
plication of "waiting days". In each country earlier regulations included a waiting period before entitlement. Subsequently these days have been reduced and abolished in the Dutch and German arrangements. Belgian procedures still prescribe one waiting day for work incapacity lasting up to two weeks, which indicates another financial consequence of sickness absence for Belgian workers.

Also medical supervision shows various modalities across the nations. The Dutch lay inspector, controlling the sick during the first days of work incapacity, is unique. In other systems the attendant physician (re-) examines work incapacity and may repeatedly issue certificates. Surveillance is exclusively executed by a medical authority, employed by the fund, organised as an independent body, or contracted by the employer. As indicated in Table 3 in Belgium not only funds but employers too have the right to require medical (re-)assessment of work incapacity. This control on the initiative of the employer usually concentrates on the first days of absence (when wages are paid normally). According to some sources supervision by social security doctors is mainly executed after this period of continuation of wage payment.

The final aspects to be considered are the financial consequences for the employer and the level and duration of benefits payment. In particular the latter factor may be essential for our measurement of sickness absence. In Belgium and Germany the employer is directly confronted with variable financial consequences of sickness absence in the work force, since benefits are preceeded by full wage payment during two, four, or six weeks. Most Dutch employers are not so directly confronted with costs of work incapacity, as benefits are paid from the first day and contributions are fixed yearly for an entire sector of industry. However, employers contributions to the Dutch sickness benefits and health care funds are substantially higher than in other countries. For 1988 in Belgium employer and employee contributed about $6 \%$ and $3.7 \%$ of gross earnings, respectively, whereas in Germany both paid on average 6.5\%. Dutch employers and insured contributed $14.5 \%$ and $6.1 \%$, respectively, for benefits and medical expenditure (Institut der Deutschen Wirtschaft, 1989).

Employees experience economic consequences as well in Belgium, to a small extend. Severe (lasting) work incapacity due to sickness inevitably causes a reduction of income. After four weeks Belgian incapacitated workers (wage earners and salaried employees) are faced with a $20 \%$ loss of net earnings. In the German situation only the majority of salaried employees and minority of wage earners are being faced with a small income reduction. Although in both countries voluntary company arrangements may provide an additional income, Dutch workers obviously experience least income reduction, since their income replacement rate is $100 \%$.

Another remarkable feature of Belgian arrangements is payment of higher benefits in case of occupational injuries and diseases. The "privileged" treatment of occupational injury victims has been abolished in both other countries in the 1960's (Kaim Caudle, 1973). Finally, duration of benefits payment in case of sickness is fixed in Belgium and the Netherlands (52 weeks), whereas the German system applies a more flexible period (maximally 78 weeks). Continuation of work incapacity may lead to entitlement for invalidity pension, 
rehabilitation, or unemployment, depending on eligibility criteria for each contingency.

Our comparisons suggest that in two of our countries under study the phenomenon of sickness absence has a narrower scope than in the remaining one. Under Belgian and German conditions sickness absence formally only covers absence from work due to illness. Consequently data sources from social security administrations may be burdened with some serious limitations. Waiting days, distinct periods of continued wage payment, dissimilar legitimation procedures, as well as differences in maximum duration of benefits payment may seriously affect the comparability of definitions and data. A close inspection of available social security statistics or employers surveys will be necessary to find out whether these or alternative data sources (e.g. household surveys) can provide adequate information for our inquiry.

\subsection{Summary}

This chapter examined the institutional context of sickness absence in each country, i.e. the legal and administrative aspects of health-related work incapacity. The comparison threw some light on some striking differences and remarkable similarities between the three systems under study. An over-all picture of the social security context, which sets conditions for sickness absence in each country, might characterize the three systems as follows.

Belgian arrangements and procedures seem to be closest to the traditional continental type of social insurance. Both employers and employees are immediately confronted with the financial consequences of work incapacity due to sickness. Incentives to limit claims (waiting days, low wage-benefit ratio) as well as surveillance procedures (doctors certificate on first day, medical supervision by various doctors) have been more developed here than in both other systems. A traditional distinction between employment risks (occupational injuries and diseases) and social risks ("ordinary" illness) is manifest both in legal, administrative and economic aspects. Finally, the social division between wage earners and salaried employees, produced by traditionally more favorable conditions for the latter (administrative, technical and professional staff), is obviously still most meaningful in Belgian regulations.

At the imaginary continuum ranging from social insurance-oriented arrangements to social security-oriented systems the German arrangements seem to take an intermediate position. This system shows similarities with both the countries on the "extreme" positions. Common to the Belgian system with its strict insurance-like system are a separate injury insurance scheme, direct financial involvement of employers with costs of work incapacity, as well as compulsory medical certification. However, other aspects are less rigid: the restriction of certification to work incapacity of over three days, a higher wage-benefit ratio ( $80 \%$ of gross earnings) and abolition of waiting days reflect the comparatively intermediate position of German regulations. Also the administrative and economic differences between workers and employees have diminished considerably in the last 30 years.

Finally, Dutch regulations and procedures are most remote from insurance principles and, consequently, show the most striking differences with the 
Belgian situation. An extended definition of sickness absence (including illness, injuries, impairment and confinement) is in operation from 1967 on. Also the absence of certification, no loss of income during sickness and no direct financial consequences for the employer ${ }^{(8)}$, as well as no social division between wage earners and salaried emloyees characterize this system.

It is suggested that this heterogenity of social security aspects will affect the equivalence of sickness absence concepts applied. It may further be expected that cross-national comparisons based on data from sickness and injury benefits administrations will probably be faced with several restrictions. 


\section{NOTES}

(1) Feedback on an interim report (Andriessen \& Prins, 1983) and its German translation (Prins, 1984) also proved to be an useful way to ensure sufficient insight.

(2) The difference between both wage-benefit ratios is due to the in- or exclusion of wage supplements (e.g. for shift work), social security contributions, or taxes.

(3) Since 1.11 .1986 the period of continued wage payment for wage earners has been extended to two weeks.

(4) Personal communication from Dr. H. Salowsky, Institut der Deutschen Wirtschaft, Cologne.

(5) The Wage Payment Continuation Act (1969) provided a seperate scheme for employers of fewer than 20 workers. For this category a compulsory insurance was continued and administered by the sickness funds.

(6) Since 1-1-1985 a reform of the Sickness Benefits Act reduced benefits from $80 \%$ to $70 \%$ of daily earnings. Most collective labour agreements were subsequently changed and provide a larger supplement to continue $100 \%$ income replacement. In most industrial sectors employers re-insured these waiting days and supplements.

(7) Before 1988 maternity leave period lasted only 12 weeks.

(8) With an exception of those employers who operate comparable income maintenance arrangements on their own account. 

PART II

A COMPARATIVE ANALYSIS 



\section{METHODS AND MATERIALS IN THIS STUDY}

\subsection{Specification of central questions}

For this explorative part of the study we actually are interested in the "differences in sickness absence rates (that) may be observed between workers in Belgium, Germany and the Netherlands". This general question may be specified into several sub-questions. For the countries under study, further insight is required into:

a. the magnitude or range of differences;

b. the type of differences, referring to frequency and duration of sickness absences;

c. the consistency of differences, specifying whether differences observed cover the entire populations or are shown to be restricted to certain branches, subpopulations, etc;

d. other relevant aspects of sickness absence, e.g. trends and relationships, insofar as valid information is available.

In order to choose an appropriate research design we will firstly consider current data sources on sickness absence in the countries under study. Attention will be focussed on methodological aspects considered in Section 2.1, namely concepts applied, populations covered, basic data sources and specifity of information (variety of sickness absence indicators, number of population characteristics measured, etc.). Subsequently conclusions will be drawn on the comparative design to be applied, selection of sources and data collection method.

\subsection{Current data sources on sickness absence}

Regarding sickness absence statistics the Belgian situation is most unfavourable for comparative studies (cf. Table 2.1.) as well as for intranational research. Generally stated, neither social security bodies nor industry provide data that might meet our requirements sufficiently. The only macro-statistical data available are yearly overviews from the sickness and invalidity benefits administration. These sources show serious limitations, however (Lebeer, 1981; Adriaenssens, 1985). They only cover certified work incapacity attributed to sickness and confinement. Temporary work incapacity due to occupational injuries stay out of sight as (private) administrations for this contingency do not report their statistics. Furthermore reliable data on the Belgian populations at risk (number of insured or employed persons) are limited. Finally, work incapacity due to sickness is only partly covered in statistical data, namely in sofar as benefits have been paid. Therefore, sickness absence during the periods of continuation of wage payment (wage earners: one or two weeks; salaried employees: four weeks) are not included.(1) Lebeer estimates that the 
statistics based on sick funds administrations regard "only one-third of total absenteeism", which probably refers to the number of absences included (Lebeer, 1981, p. 101). Besides, as sickness absence is not experienced as a serious problem in Belgium, neither investigators nor industry have developed reporting systems or a research tradition on the subject as in the Netherlands. In certain regions or sectors employers associations collect absenteeism figures but these are fragmentary and not always published. This poor data collection seems to limit the choices for our research design seriously.

In Germany legal requirements and administrative organization also determine the lack of integrated statistics on work incapacity or sickness absence. Several sources have to be explored, but the picture is essentially more promising than in Belgium. Basically, four types of statistics are available for our study (Busch, 1982; Pfaff et al., 1986):

a. The Federal Bureau of Statistics provides monthly point prevalence rates ("Krankenstand"), indicating the percentage of insured with certified work incapacity due to sickness, as measured by sick funds on the first day of each month;

b. Statistics based on process data from benefits administrations are published regularly. The main associations of sick funds, covering distinct parts of the population of insured, provide yearly sickness absence rates on severity, frequency and average spell duration of certified and completed work incapacity due to sickness. Information on characteristics of the populations at risk is limited, however;

c. A yearly survey ("Mikrozensus") among a representative sample ( $1 \%$ fraction) of the German population also furnishes information on absence from work in the four weeks before the interview week (in April);

d. Finally, the research institute of the Federal Labour Bureau (Institut für Arbeitsmarkt und Berufsforschung) integrates some data from previous sources in their publications on working time, labor market, etc.

Both data suppliers and researchers suggest certain restrictions on the rates available. Main limitations regard the types of work incapacity measured (exclusion of short term and non-certified absences), populations covered (about $20 \%$ of the employed are not compulsory insured), and little information on population characteristics (e.g. age and occupational structure). Furthermore, work incapacity due to occupational accidents is not included in sickness benefits statistics, but is available from other sources.

For the Netherlands three main sources of information on sickness absence can be found. Firstly, publications based on aggregated process data from sickness benefits administrations contain information on frequency, severity and duration of completed spells of sickness absence in a calendar year for which benefits have been paid. Several types of work incapacity are included (sickness, injury, maternity leave periods) but they cannot be distinguished reliably. These statistics cover some $80 \%$ of the employed in agriculture, industry, commerce and services. Sickness absence in the remaining $20 \%$ of employed persons do not enter these statistics since certain (large) employers administer sickness benefits on their own account (cf. Section 3.2). Furthermore, statistics based on benefits records may be deficient in very short spells notifying which 
involves the employer in additional paperwork. A final restriction of Dutch social security statistics is the lack of recent information on size and composition of the population of insured. These characteristics have to be estimated from labour force surveys.

For 30 years a second source of statistic information on sickness absence has been available in the Netherlands. After World War II concern about this phenomenon and interest among prominent occupational physicians gave rise to a voluntary reporting system, operated by the Netherlands Institute for Preventive Health Care (NIPG/TNO). Nowadays this system collects on a voluntary base sickness absence data from about 270 firms and industries employing 212.000 persons (1988). Frequency and severity rates are regularly published by the Central Bureau of Statistics. This source provided information on sickness absence in the Netherlands for most macroscopic studies discussed in section 2.2 and gave rise to an extended research tradition on sickness absence.

Furthermore, a smaller sample of employees from industry, commerce and services provide most detailed data in sickness absence and work force for the sickness absence information system of the Netherlands Institute of Working Conditions (NIA). Notwithstanding, for the purpose of our comparisons the highly selective composition of the populations covered may restrict the direct application of these latter sources here. Additionally, it should be mentioned that every two-years a "Life Situation Survey" is carried out among a sample of the entire population in the Netherlands. Information on sickness absence (days absent due to sickness in last three months) is restricted and from individual recal rather than personnel records.

\subsection{An evaluation in the light of the central problem}

Examination of available research, income maintenance arrangements and data sources gives an important insight in methodological conditions and empirical limitations for our inquiry. Epidemiologically oriented authors like Field (1975), Pflanz (1975) and Taylor $(1969,1972,1983)$ enlarged our knowledge of presuppositions and criteria for making valid comparisons. The overviews of social security regulations and available data sources, however, demonstrated that procedures, concepts and statistics generally do not make allowance for these requirements. One major conclusion can already be drawn: data based on regular health interviews or household surveys will be of limited value for our inquiry as this source is not available for Belgium. Furthermore both in Germany and the Netherlands sickness absence rates derived from surveys show serious restrictions.(2) We will outline our further conclusions, following a slightly revised version of our previous criteria.

The lack of equivalence of concepts and measures is shown to be the main problem area for a comparative study of sickness absence; three restrictions have been indicated. Management-oriented and company-based rates on "absenteeism" may include non-medical spells: days lost due to absence for personal reasons, industrial disputes, etc. Furthermore, sickness absence definitions may or may not include (occupational) injuries, confinement periods, rehabilitation periods, etc. Finally, international differences in entitle- 
ment criteria (waiting days, certification requirements, continuation of wage payment) seriously restrict the comparability of concepts and indicators. This aspect particularly makes available Belgian social security statistics highly incomplete and inappropriate for our study.

The equivalence of populations may create some difficulties too. Differences between nations could be observed regarding the coverage of the populations of (compulsory) insured (and, therefore, exclusion of higher income groups) or the inclusion of certain economic sectors (mining, agriculture). Sometimes the size of the population of insured is not known exactly. Industrial statistics have their limitations too: they differ in the inclusion of salaried employees, temporarily employed workers, etc. As has been shown by Taylor (1972), household surveys may exclude long-term sick persons. Whereas all categories of employed are basically covered in Belgian and Dutch social security statistics, some small groups of highly paid employees may not be included in German sources.

The reliability of basic sources is predominantly affected by legal requirements and procedures in benefits administration, recording conventions in industry or survey methods applied. From each of the countries under study data restrictions were reported, e.g. regarding the recording of 1-3 day spells, the inclusion of sickness absence during periods of continued wage payment, or the sample of households interviewed during a defined period. A final point to be mentioned are differences in the calculation of rates: units of measurement (calendar days or working days lost, days of certified or paid work incapacity), estimates of population magnitude, etc may vary. In this respect data from all countries show certain limitations.

In the light of the previous criteria, the specificity of information may seem rather a "luxury" or sophisticated wish. Meeting the former criteria satisfactorily can give a valuable insight in the scale of international differences in sickness absence. The nature of these differences, however, stay out of sight. If for each country one crude indicator is used, only expressing the magnitude of the problem (e.g. percentage days lost or point prevalence rates). Fundamental constituents of sickness absence, like frequency and duration of spells, remain unknown. A minimum set of indicators should contain rates for these measures too (Taylor, 1983). Only a very limited number of studies and some benefits administration statistics include the latter indicators as well.

A second aspect of specificity regards the control of crucial confounding factors (e.g. age structure and occupational composition of the populations compared). Only some mesoscopic studies and very few social security statistics provided data on basic population characteristics. However, for a satisfactory cross-national comparison of sickness absence, at least some information on age, sex and type of work of the populations should be available.

Regarding this state of affairs two further observations can be made. Firstly, of course all these sources of incongruities in definitions and measures do not have equal consequences for available or calculable sickness absence rates. 
For instance, incomplete coverage of short term sickness absence (e.g. one three days) seriously affects the frequency rate but hardly the percentage days lost. Partial inclusion of long term sickness absence will strongly bias the severity rates and average duration rates but it hardly affects frequency rates. Furthermore, incomplete coverage of voluntary insured and their sickness absence will lead to an overestimate for the whole population since this category of employed persons generally shows relatively low sickness absence rates. For any interpretation of international differences such sources of bias should be removed.

Secondly, controlling available data for conceptual and technical sources of bias is not always possible, however. Basic information on population characteristics is often lacking; studies on which reliable estimates for "missing cases" of short term sickness absence or injury-related sickness absence might be based, are not always available. So the investigator restricted to the available information hardly has opportunities to adjust data for obtaining better estimates.

\subsection{The choice for a cross-organizational comparison}

From this analysis of conceptual aspects and research conditions the conclusion can be drawn that macroscopic data contain many incongruencies and sources of bias which restrict a valid and detailed analysis of sickness absence indicators. A comparison on company level offers much more opportunity to ensure comparability and specificity of sickness absence rates. This will particularly be the case, when individual (crude) data on all relevant types of absences and population characteristics can be collected from company records. The choice of comparing sickness absence rates at company level would satisfy the previous criteria perfectly:

- firstly, equivalence of concepts and measures is not to be achieved by laborious adjustment or correction of available sickness absence rates: the similarity can only be created at the onset by the investigator. A common operational definition, applicable in each firm can be constructed and may be measured directly by collecting appropriate sickness absence data from employees records;

- secondly, in this strategy a strict definition and demarcation of the populations at risk is facilitated, as similar categories of employed persons may be selected and small "problematic" categories (e.g. part time workers) may be excluded to facilitate calculation and comparison;

- thirdly, it may be expected that records kept by employers contain reliable basic information allowing the calculation of standardized sickness absence rates by the investigator.

This method of direct and valid measurement also gives the opportunity to consider various sickness absence indicators. And the collection of certain additional population characteristics from personnel records further allows an analysis of confounding factors, high risk groups, etc.

The application of data from company records has some restrictions too, however. Not only an accurate selection of firms and data collection proces may put a burden on the inquiry. But recorded data will only be available for a 
restricted period, and therefore restrict the investigation of some research questions, e.g. as to trends in sickness absence rates. So, the research strategy to be followed will not only depend on actual data conditions in each country, but also on specific questions underlying our central problem (magnitude, type and consistency of differences, as well as trends or country-bound aspects).

As a straightforward solution one may suggest the comparison of sickness absence rates in three random samples of firms in the countries concerned. There are, however, several reasons to reject such a design. Firstly, the investigation of considerable samples of firms may be appropriate and feasible in cross-regional studies of sickness absence (e.g. Soeters, 1980). For a crossnational investigation both internal facilities (funds, staff, equipment) and external conditions (unknown population of firms, high non-response risk in countries with small research tradition) do not permit such a design. Secondly, we are not interested in the "real" or representative absolute sickness absence rate for each country, but merely in their "relative" rates. The study focusses on the relationships between them : the magnitude and pattern of their differences are relevant. This insight may be gained by observing consistent differences in sickness absence rates from a few firms in each country, provided elementary confounding factors will be accounted for. Finally, the comparison of a restricted number of firms has an important advantage too for the explanatory part of our study. For an insight in potential organizational determinants of observed differences a relatively intensive study of a few cases may be of greater value and easier carried out than a broad but necessarily global approach based on many firms in each country.

Consequently, it was decided to carry out a few case studies, each case consisting of a international "triad" or cluster of comparable firms. Furthermore, as a comparison of trends is less sensitive to differences in measurement, the answer to the fourth question may be gained by using macroscopic statistics (cf. Taylor, 1969; Pfaff et al., 1986).

\subsection{Case studies and controlled comparisons}

Traditionally the case study design is considered as a strategy with many restrictions. Lack of methodological rigor ("researcher bias") and small external validity (generalization) are considered to be major limitations. Furthermore, it is often suggested that case studies "take too long and result in massive unreadable documents" (Yin, 1984, p. 21).

However, under certain conditions, some of these restrictions can be reduced whereby the major advantages of this design - insight in the phenomenon in its "real-life context" - may be utilized. To that end we need control over sources of variation on various levels of analysis. Differences in sickness absence rates among Belgian, German and Dutch employees may be due to a multiplicity of conditions and factors, operating on the individual level (e.g. age, sex), organizational level (e.g. working conditions, personnel policy) and macro-sociological level (e.g. social security regulations, social attitudes on work and health). From Chapter 3 we already know that on the latter level social security factors vary considerably between the three countries. Furthermore, research in many countries indicates similar relationships have been noted between factors on 
both other levels and frequency or severity of sickness absence (Smulders, 1984a).

The application of the case study design may now be appropriate to investigate cross-national differences, if three requirements can be met:

1. sickness absence rates are compared within a cluster allowing control of main confounders on individual and organizational level;

2. the case study can be replicated under various conditions for which similar results can be predicted. To that end clusters must be created and studied in different sectors;

3. findings from all case studies are highly consistent. If the cases show similar results this may be considered as compelling support for the initial conclusions.

The method of comparison within several clusters may be defined as a "multiple case study design with controlled comparisons". Gaining control over sources of variation will be achieved by two strategies (Smelser, 1976; Anderson et al., 1980). On the one hand by selecting cases that resemble each other in significant respects. This matching strategy implies that these similarities can be regarded as "ruled out" as explanatory factors. On the other hand by applying statistical techniques on cluster populations for which (potentially) confounding factors have been measured.

As criteria for the selection and matching of firms three organizational characteristics have been chosen. In many studies they have been shown to influence sickness absence rates (Trebesch, 1979; Smulders, 1984a). Moreover, they can be rather easily verified during the acquisition of organisations for the project. The major selection criterion for each cluster was resemblance of product and production process. This variable is associated with sickness absence, mainly exerting influence by intervening variables such as type of work, working conditions and stress. By creating clusters matched by these characteristics these variables may be assumed not to vary.

The second criterion to be applied is organizational size. Literature often indicates a curvilinear relationship with sickness absence: large and small firms show lower sickness rates than medium size organizations, which might be due to variations in social climate, industrial relations, quality of supervision, etc.

If the fullfilment of these critera still leaves room for choice the sociogeograpbic location of firms will be considered. Firms in rural areas commonly show lower sickness absence rates than those in urban regions, which might be attributed to differences in value orientations or living conditions of employees.

The second strategy to control confounding factors has already been indicated in the review of literature and available data sources (Section 2.4 and 4.2). Primary variables as age, sex and occupational status will be controlled for by statistical techniques like standardization and multivariate analysis. To that end for each employed person in the firms some basic characteristics have to be known, which will require a considerable data collection in the project. It may be concluded that the selection strategy as well as measurement of sickness absence and in particular population characteristics, will be of considerable importance in this design of controlled comparison. 


\subsection{Definition and measurement of sickness absence}

As a preliminary guideline on the examination of previous investigations and available data sources we made use of the Dutch concept of sickness absence. It covers absence from work due to illness, injury, confinement or maternity leave. Now we will consider whether this definition is still appropriate and applicable in carrying out case studies on organizational level. The comparison of the social security context of sickness absence in each country showed that the legal and administrative concept of sickness absence differs considerably between the countries under study. In the Belgian and German social security context sickness absence ("Ziekteverzuim", "Krankenstand") only covers medically legitimated work incapacity due to sickness. The Dutch term includes other types of health related absence too, without any medical legitimation at the onset.

At company level the definition and context of sickness absence is fundamentally economic and management-oriented. In most firms some kind of absence reporting system is applied to provide information for manpower planning, pay purposes and absence control. Information from foreign companies, research reports and personnel management literature demonstrate a variety of concepts, absence categories and measures (Trebesch, 1979; Maib, 1981; Iken \& Haberkorn, 1981). The over-all non-unitary concept labelled "Absenteeism" ("Absenteeisme", "Fehlzeiten", "Arbeidsverzuim") usually includes four main categories of absences:

a. absences with legal or contractual basis, e.g. annual leave, maternity leave, birthday, death in family, study leave, preventive treatment prescibed by social security funds in Germany ("Kur"):

b. certificated sickness absence;

c. absence from work due to injury (work related or domestic);

d. absences for other reasons, e.g. non-certificated absences, strikes.

As Dutch work incapacity regulations do not differentiate between types of risk, the latter often are not distinguished in company records either. In Dutch company recording systems therefore three broad categories of absences may be discerned, namely:

1. absences on legal or contractual basis (like a. but maternity leave excluded);

2. sickness absence, combining elements from a-d, namely covering maternity leave (a), absence due to illness (b), and injury (c), and those absences due to illness which have not been certificated;

3. absences for other reasons.

In the light of the conceptual pluralism and variety of recording conventions one conclusion is obvious: the Dutch concept of sickness absence should be applied further. As this concept can not be narrowed adequately to resemble foreign terms, equivalence in concepts and measurements can only be reached by selecting those types of absence from Belgian and German company records which, in combination, are equivalent to the Dutch term and indicator. So for our comparative purposes sickness absence covers health-related temporal absence from work due to illness, injury (occupational, domestic), confinement and maternity leave. As no medical evidence is required from German salaried employees for 1-3 day absences, these non-certificated absen- 
ces attributed to illness will fall within the scope of our definition too. Finally, absences due to preventive or curative treatments, prescribed by social insurance bodies ("Kur", "Heilverfahren") will also be covered.

Not only concepts, but also their measurement, should be (made) equivalent. Therefore, in accordance with Dutch and Belgian benefits payment regulations the maximum period of a spell of sickness absence will be standardized to 365 days. Taking account of this maximum the observation period has been chosen as two years, allowing a minimum of insight in the constancy of differences.(3)

An essential assumption of our choice relates to the underlying dimension of our concept. In this study, as in most Dutch investigations on this subject, sickness absence is primarily defined as a health-related phenomenon. In a manager-oriented or psychological approach much attention is usually paid in attempts to discriminate between "genuine" sickness absence and absence for non-medical reasons, the latter often being considered as the one to be controlled. In this respect the term "absenteeism" is often used with a pejorative flavour: it indicates a category of absences which, although partly presented as health-induced, basically might be attributed to non-medical reasons like low morale, poor motivation and little job satisfaction, or social conflicts (Nieder, 1979; Chadwick-Jones et al., 1982). Efforts to distinguish these absences validly from "true" sickness absence are quite arbitrary, and will not be applied here. In the exploratory stage of our study we will consider sickness absence mainly from a epidemiologically oriented viewpoint, namely as an indicator of health problems. Of course we are aware that this indicator is weaker than morbidity statistics; the validity of sickness absence as a health indicator will be reexamined and discussed more fruitfully in the light of our findings and interpretation (cf. Chapter 11).

\subsection{Acquisition and selection of clusters}

From the beginning it was clear, that our cross-national study could only be carried out by what is sometimes pejoratively called "safari research" (KarsMarshall, 1983). In this strategy the entire inquiry is made by a (group of) researcher(s) from one country, collecting information in other countries, but analysing and reporting findings "at home". Funds and research facilities (e.g. data processing) did not allow however a strategy usually recommended by advocates of cross-national research: having the design, measurement, analysis and report made by coordinated researchers in each country. We have the impression that in our simpler strategy sources of researcher bias could be sufficiently reduced. Both contacts with experts (from social security institutions, employers organizations, labor union institutes) and feedback from Belgian and German investigators acquainted with the subject as well as personnel managers from firms approached, proved to be highly fruitful and corrective during several stages of our project.

From summer 1982 middle range and large firms were approached to participate in the project. Multinational enterprises, employers organizations and informed experts (social researchers, authors) provided names of firms that 
might be interested and meet our requirements. In this acquisition process not only selection characteristics (comparability regarding product, size, location) were relevant. The firms should also maintain an adequate sickness absence recording system and show sufficient motivation, as the collection of data would cause some extra work. Each potentially interested firm was visited to explain the background and aim of the study. An "intake interview" with the personnel manager provided information on product and production process (technology, etc.), work force (shift work, work time arrangements, etc.), recent organizational changes (lay-offs, reorganisation, etc.) and sickness absence (magnitude, policy, etc.). Finally, internal recording, reporting and calculation procedures were inspected and documented.

About 25 firms were visited and all except two were quite interested and motivated to participate in the project. However, a "suitable" organization was only to be included in the study if in each of the other two countries a similar firm could be found. Eleven firms had to be excluded for technical reasons (inadequate data sources) or because of the lack of comparable firms to complete a cluster. After nine months four international clusters from various economic sectors had been formed. Alas, during the data collection stage one German firm withdrew. Time was too short to find an appropriate alternative, so one cluster remainded incomplete. In the end four Belgian, three German and four Dutch firms provided the opportunity to collect data from their employees.

It is well-known that considerable regional differences may underly the general sickness absence levels in a country. E.g. in the Netherlands it was found the comparatively high sickness absence rates in the Southern Limburg area might be attributed to life style-, health care- and economic factors (Soeters, 1980). Regional differences are also documented in German sick fund statistics and some occasional investigation (cf. Halusa et al., 1987). Belgian regional differences are less well documented. However, it was often stated that employees in the Wallonian region, having a different and older socio-economic structure (mining, heavy metal industry), also show somewhat higher absence and injury rates than in the Flemish part of the country.(4) Our German and Dutch firms are well dispersed over the country, but all Belgian firms are located in the Flemish region. So we have to face the risk that due to regional factors our Belgian data may be somewhat biased downward (cf. Section 5.1).

\subsection{Data collection}

Before the actual process of data collection started the cluster populations were to be precisely defined and demarcated. Some small categories of employed persons have been excluded from the work force as their attendance or sickness absence was not always adequately recorded, or because their inclusion would complicate the calculations. Thus, following minor categories of personnel were not included:

a. persons with special contracts, employees with temporary contracts, trainees, free lance workers;

b. persons temporarily not attending work because of military service;

c. persons incapacitated for over 365 days but still on the pay roll at the start of our observation period; 
Therefore, the populations to be compared consisted of all persons permanently employed in the observation period 1.1.1980-1.1.1982. They also include small groups of part time workers and those employed with a partial invalidity pension.

For an efficient and reliable collection of data in this population the "sickness absence recording system" operated by the former CCOZ Foundation was indispensable. Since 1976 this system collects and provides detailed information on the extent, nature and development of sickness absence in a large number of firms. A slightly altered version of this system could be used to collect data, calculate rates and create a data base for future statistical analysis. To this end three (national) versions of recording instructions and procedures were made and discussed with an expert from the personnel management departments involved. Special attention was paid to the protection of privacy: population characteristics and individual absence data were to be measured whilst ensuring anonymity.

\section{Table 4.1 Overview of population characteristics measured}

\begin{tabular}{|c|c|c|c|}
\hline & CHARACTERISTIC & VARIABLE & VALUE \\
\hline 1. & Date of birth & age & continuous \\
\hline 2. & Date of engagement & seniority & $"$ \\
\hline 3. & Date of withdrawal & person years & $"$ \\
\hline 4. & Reason for withdrawal & turnover & $\begin{array}{l}\text { withdrawal on own initiative; } \\
\text { dismissal; transfer to invalidty } \\
\text { pension; retirement; deceased; other }\end{array}$ \\
\hline 5. & Sex & idem & male; female \\
\hline 6. & Nationality & idem & $\begin{array}{l}\text { optional: Belgian-migrant; German- } \\
\text { migrant; Dutch-migrant. }\end{array}$ \\
\hline 7. & Department (as at 1-1-81) & idem & optional \\
\hline 8. & Shift work (as at 1-1-81) & idem & $\begin{array}{l}\text { None; two cycle shift; } \\
\text { three cycle shift; other. }\end{array}$ \\
\hline 9. & $\begin{array}{l}\text { Occupational status } \\
\text { (as at } 1-1-81 \text { ) }\end{array}$ & idem & $\begin{array}{l}\text { manual workers; } \\
\text { salaried employees }\end{array}$ \\
\hline 10. & Wage group (as at $1-1-81$ ) & idem & optional \\
\hline
\end{tabular}

The variables used are a selection of those usually measured in the CCOZrecording system (cf. Table 4.1). They provide basic information to calculate the size of populations (e.g. 2, 3), to account for the main determinants of sickness absence (e.g. 5, 9, 10) and to study effects of specific factors (e.g. 4, 6). In most firms information on this selection of variables proved to be available without many problems. For only one category of workers, namely those who left the firm in the observation period, data on some variables was not available (e.g. reason for leaving the firm, occupational status, wage group). For every employed person two items of data were recorded from every spell of sickness absence:

1. the first day of sickness absence;

2. the day on which work was resumed (or the day of transfer to invalidity pension).

This data has been collected for every spell of sickness absence which was completed between 1.1.1980 and 1.1.1982. For German and Belgian companies 
the type of sickness absence has often been recorded too. The process of data collection took several months and required a lot of work, patience and flexibility for the research team. The information was acquired in several ways. One large firm provided data by computer tape, whereas two firms supplied computer lists with anonymity of personnel data. Subsequently research assistants, familiar with sickness absence statistics, recorded related sickness absence data by hand from company records. In one firm personnel characteristics and sickness absence data have been recorded on code sheets by an employee, according to prescribed guidelines on the project. Finally, for seven firms research assistants recorded the required information on code sheets during a stay at the personnel management departments.

Usually errors and missing values could be resolved by obtaining additional information from the firms. In particular for Dutch firms the variable "occupational status" needed close attention as this characteristic is almost obsolete in the employment situation.(5) After cleaning and recoding raw data, the project participants received several statistical summaries of their sickness absence rates over 1980 and 1981 . These reports provided firms with detailed insights into their sickness absence rates, which most of the time had not been available before. Furthermore, they provided another opportunity for corrections and general feedback.(6) This extensive data collection proces provided sufficiently reliable information on sickness absence in 1980 and 1981 of 11.127 employees of eleven companies in the three countries under study.

\subsection{Summary}

This chapter examined the issues underlying the research strategy to investigate the first question stated: "Which differences may be observed between sickness absence rates of workers in Belgium, Germany and the Netherlands?". After considering the available data sources in the three countries under study the conclusion was drawn that they could hardly provide adequate data for a valid and extensive comparison of sickness absence levels. Conceptual, administrative and statistical sources of bias would be better and more easily accounted for by using crude data from selected firms which resemble each other. It was decided to apply a multiple case study design with controlled comparisons. The individual level of measurement provided the opportunity to ensure a standard definition and measurement of sickness absence. Besides data collection on population characteristics was facilitated to allow control of several confounding factors. But limitations of this choice (e.g. short observation periods) also had to be taken into account. So to provide an answer to some sub-questions appropriate macro-statistical data and local literature will be indispensable (e.g. regarding recent trends in sicknes absence rates).

Four clusters of firms were selected but the withdrawal of one firm restricted the number of German firms to three. Further it should be noted that all Belgian firms are located in the Flemish part of the nation, which generally may have a somewhat lower sickness absence level than in the Wallonian region. Firms comprising a cluster were matched on the basis of their product and type of technology. Company size and as far as possible geographical location were also selected as selection criteria. It proved to be necessary and 
fruitful to continue the application of the Dutch concept of sickness absence, which includes work incapacity due to illness, injury, confinement or maternity leave, irrespective of whether medically attested or not (with a maximum duration of one calendar year). The sickness absence data and population characteristics (over the observation period 1.1.1980 - 1.1.1982) were collected by hand or computer tape and cover 11.127 employees from eleven companies. 


\section{NOTES}

(1) Comparing data on sickness absence from company records and sickness benefits statistics Adriaenssens concluded in the case of wage earners $16 \%$ of sickness absence days and $57 \%$ of spells of sickness absence were not covered by benefits-related rates. For salaried employees these percentages were $47 \%$ and $88 \%$, respectively.

(Adrianssens, 1985, p. 86).

(2) Pfaff et al. (1986) found work incapacity rates from the "Mikrozensus" were just $1 / 4$ or $1 / 3$ of rates derived from sick fund administrations. And also Dutch health interview survey figures indicate a serious underestimate of the frequency of short absences (Ziekteverzuim, 1986).

(3) The methodologically oriented selection of our sickness absence concept implies that rates calculated for Belgian and German firms a priori will differ from their own. The categories included may cause a relatively small increment compared to company rates. On the other hand the fixed maximum duration of one calendar year may exert a decrease in our rates in the case of long term sick (over one year) remaining on the pay roll.

(4) A comparison of regional differences in the average number of days of benefit payment per insured (covering a part of entire sickness absence) also suggests regional differences. In the Flemish region three out of four provinces show rates above national average. But the province with highest rates (Limburg) is also found in this part of the country. With one exception the Wallonian provinces generally score higher than on average. These findings are not consistent when compared across sex and occupational groups. (Information based on RIZIV and personal communication from Mrs. De Boeck, Rijksinstituut voor Ziekte- en Invaliditeitsverzekering).

(5) Therefore, after consultation with the personnel manager, values of this variable have been assigned to employees according to their type of job. Despite this concise attempt the validity of their particular variable may be restricted for the Dutch population.

(6) Afterwards it came out that in some Belgian and German firms these reports had been studied seriously, especially tables differentiating between departments, shift cycles, etc. 


\section{FOUR CASE STUDIES}

\subsection{Description of cases}

The clusters for our investigation were selected from three different sectors of industry (Chemical, Food and Metal industry) and they are labelled by their major products: paints, margarine, frozen foods and tins, respectively. From Table 5.1 it may be concluded that in spite of our efforts the matching of firms could not be totally succesful. Regarding the first selection criterion - product and production process - in each cluster resemblances are striking. Within each cluster products and production technology are very similar between firms; sometimes even the same type of machines were in operation (i.e. in margarine and tin cluster). However, on the second criterion (organizational size) two clusters (nr. 1 and 3) vary considerably. These differences are partly due to the inclusion or exclusion of (large) departments for "research and development" or "sales and marketing". For these clusters the effects of incomplete matching may partly be avoided by comparing similar sub-groups (e.g. departments) instead of the entire populations. Finally, the sociogeographic location of firms in each cluster was very similar, which is not surprising in the light of similar production conditions. Transport facilities for basic materials may have situated all margarine firms in major ports whereas frozen conservation of vegetables, etc. is generally located in rural regions.

Table 5.1 Main characteristics of four clusters (1980)

\begin{tabular}{rlllll}
\hline $\begin{array}{l}\text { Matching } \\
\text { criteria }\end{array}$ & \multicolumn{5}{c}{ Clusters } \\
\cline { 2 - 5 } & 1 & 2 & 3 & 4 & Total \\
\hline Product & Paint & Margarine & Frozen Food & Tins & - \\
& & & & & \\
Pop.Size B & 671 & 694 & 299 & 585 & 2249 \\
G & 1737 & 839 & 663 & 783 & 3488 \\
N & 1219 & Urban & Rural & Rural & - \\
Location B & Urban & Urban & Rural & - & - \\
G & Urban & Urban & Rural & Rural & - \\
N & Ur/Rr & & &
\end{tabular}

During the acquisition and data collection some additional features of the participating firms became obvious. Firstly, regarding the level of sickness absence, it came out that for each country not only high or low scoring firms have been chosen. The firms selected from each country do not show sickness absence rates that are atypically high or low for their branches of industry. According to local data from national or company statistics in Germany and the 
Netherlands some firms were above but others were under or at the average level for their branch or sector. For Belgian firms the relative position on the "sickness absence scale" in their sector, as estimated by the personnel manager, also showed variations.

Furthermore nearly all Belgian and German firms, related to multinational enterprises, provided extra-legal supplementary social insurance arrangements for some categories of their workforce in case of work incapacity. So in the social security context most firms show more favorable or liberal (certification) conditions than the ordinary rank and the file firm in their country.

Finally, it came out that the Dutch selection was biased vis-à-vis the administration of work incapacity benefits. All firms operate an income maintenance arrangement for work incapacity on their own account, instead of affiliation with the industrial association of their branch (see Section 3.2). Therefore, among other things, medical supervision is partly or totally in the hands of the occupational physician. There are indications that this kind of firm generally has lower sickness absence rates than firms being members of an industrial association (Nederlands Instituut voor Preventieve Gezondheidszorg, 1983). However, the comparison of firm absence rates with average sector figures did not suggest that our Dutch selection showed rates severely biased downward.

\subsection{Comparative strategy and measures applied}

The draft report of each case study comprised an abundance of materials and has been reviewed by the firms for validation purposes. With respect to the measures applied we used definitions and rates well known from international sickness absence research but sometimes they were altered due to Dutch recording conventions or data system conditions.

The population size of each firm has been calculated from personnel records, allowing a measurement in person years. The mean annual population is derived from person-days for each individual employed for all of some of 365 days. (1) Notwithstanding the formal nature of the indicator person-year we will often use the term "person" for sake of readability. The specific sickness absence rates applied in this chapter are the severity rate, the frequency rate and the average duration per spell.

As a severity rate for sickness absence according to Dutch conventions a lost time percentage is used. This particular rate, "sickness absence percentage" (Abbr: S.A.\%), expresses the annual number of calendar days lost due to sickness absence as a percentage of potential person (calendar) days. Multiplication of this percentage by 365 days produces the severity rate mostly found in English studies ("Days per person").(2) According to particular conditions of the data systeem applied this measure includes the total number of calendar days of sickness absence taken by each employee in a calendar year, irrespective of whether they originate from commenced or completed spells.

The spell frequency rate ( Abbr.: Freq.) expresses the average number of sickness absence in a year per person-year at risk. Calculation and reporting standards prescribe the selection of commenced spells as basis for calculating this rate ("spell inception rate").

Two indicators have been used in this study for the lenght of spells. Firstly, the average spell duration indicating the average number of calendar days per 
(completed) spell of sickness absence. Because of the statistical instability of this measure due to the highly skewed nature of its distribution the lenght of spells will also be examined by using a classification into thee duration classes. These classes (1-7 days, 8-42 days, 43-365 days) being used as standard in the recording and reporting system applied, will be used to specify frequency and severity rates. Moreover they coincide with some essential aspects of income maintenance programms in the countries under study: compulsory full wage payment lasts up to seven or 28 days for most Belgian and maximally 42 days for German employees, respectively. And for both Belgian and Dutch employees sickness benefits payment is exhausted after 52 weeks. The application of duration classes may give a valuable insight into the distribution of absences due to minor ailments and more serious causes of work incapacity.(3)

The next sections present the findings from our four case studies. For each case the pattern of differences within the clusters will be analysed in the light of the basic questions stated about the magnitude, type and consistency of differences in sickness absence rates. The outcomes from each case will be compared in Chapter 6.

Each case study dealing with differences between firms of one cluster has the same comparative structure. Firstly, the firms comprising a case will be described and compared on some organizational and population characteristics. This step may also highlight potential confounding factors. Secondly, basic indicators of the severity, frequency and duration of sickness absence will be compared across firms. They give an insight into the magnitude and structure of sickness absence differences and may throw some light on their temporal stability by comparing rates for 1980 and 1981 . When both years show the same pattern of differences, in further comparisons only average rates for the entire observation period will be used.

The third step of our analysis observes the consistency of findings and the effects of major confounding factors. This part of the analysis will be restricted to those primary determinants that generally have to be controlled for, as they are responsible for the largest variation in rates, namely age, sex and occupational status (Hogerzeil, 1972; Taylor, 1983). Influences of other variables on sickness absence differences will be regarded in following chapters.

The final part of the comparative strategy reviews the pattern of differences in a cluster by analysing of standardized absence rates. Standardization is an adjustment procedure to correct for differences in confounding factor distributions between cluster firms. The outcomes of the standardization technique are estimates of "what would have been observed had the confounding factor distributions been the same in the ... groups being compared" (Anderson et al. 1980 , p. 114). As will be shown distributions of age, sex and occupational status may vary considerably. Therefore, within each cluster a direct standardization of sick rates will be applied to these variables.(4)

\subsection{Case 1 Paint Cluster}

\subsubsection{Main characteristics of cluster firms}

The first case study compares three firms (B1, G1, N1), each producing paints, coatings and varnishes for industrial and private customers. B1 is economically 
independent, whereas the two other firms are related to (different) multinational enterprises. The Belgian and German firms are located in key industrial areas; the Dutch location operates in a mainly rural region.

Table 5.3.1 Key figures for Case 1 (1980)

\begin{tabular}{lrrr}
\hline Characteristics & B1 & G1 & N1 \\
\hline Average population size (person years) & 671 & 1737 & 1219 \\
Percentage of (direct) production workers & 57 & 56 & 28 \\
Percentage of shift workers & 0 & 42 & 7 \\
Mean age (years) & 36 & 43 & 38 \\
Mean seniority (years) & 14 & 8 & 12 \\
Percentage of female employees & 18 & 27 & 15 \\
Percentage of salaried employees & 36 & 10 & 83 \\
Percentage of migrant workers & 1 & & 3 \\
\hline
\end{tabular}

The size and composition of firms in this cluster are not completely identical (cf. Table 5.3.1). The Belgian firm is much smaller than both other cluster elements. Furthermore, B1 and G1 are predominantly factories, without substantial sales activities on their location. N1 however, has a more heterogeneous structure: production departments are relatively small, whereas the majority of the work force is employed in research/development, sales/marketing and clerical sectors. Regarding the production process a major difference is the operation of shift work. Three cycle continuous shiftwork is being done by over 40 percent of employees (males only) in G1. However, in N1 only a small proportion is doing (the same type of) shift work, whereas in the Belgian firm shift work is exceptional (only for periodic peaks in production a two cycle shift operates for a small group of workers). Finally, in the observation period G1 had a few weeks of involuntary 50\% work time reduction for production personnel; in B1 certain categories of production workers were faced with temporary unemployment in low production periods. It is well-known that such conditions (temporarily) reduce sickness absence levels although these effects may differ for various categories of personnel (cf. Nijhuis, 1984). All firms have a similar type of wage system, paying collectively agreed fixes wages without bonusses.

As Table 5.3.1 indicates the populations in this cluster differ on a few characteristics. G1's workforce is relatively old, compared with both other populations. The remarkably low mean seniority in this firm is due to a take-over in the early 1970 's. B1 has the highest proportion of female employees, mainly working in direct production areas. On the contrary, in the Dutch firm female workers are hardly employed in production (only 6\%). The notably high percentage of salaried employees in N1 is mainly attributable to the broader range of activities in this location. However, as the occupational dichotomy "manual-staff" has become rather obsolete in Dutch industry, a (re-)constructing of this characteristics was necessary. This may account for a small bias in the distribution observed, so this variable should be interpreted with care. Finally, migrant workers are employed on a small scale in G1.

In terms of the distribution of high risk groups vis-a-vis sickness absence, the German firm may seem less favourable than the other firms of the triad (more 
older and migrant workers, shift work). Because of its rather "deviant" mixture of economic activities and related work force composition, the Dutch firm might be typified by least proportion of high risk groups.

\subsubsection{First comparison of sickness absence rates}

Severity rates indicate that sickness absence is a less severe problem in B1 and N1 than in G1 (cf. Table 5.3.2). Rates are lowest among Belgian personnel, being the highes in G1. Employees of the Dutch firm show an intermediate sickness absence rank. Frequency rates demonstrate a slightly different pattern, however, B1 employees take least absences due to sickness, spell frequency rates being the highest for N1.

Table 5.3.2 Annual sickness absence rates (severity, frequency, average duration) in Case 1 (1980, 1981, 1980 and 1981)

\begin{tabular}{|c|c|c|c|c|c|c|c|c|}
\hline Year & Firm & $\begin{array}{l}\text { No. of } \\
\text { persons }\end{array}$ & $\begin{array}{l}\text { \% Days } \\
\text { per } \\
\text { person }\end{array}$ & Index & $\begin{array}{l}\text { Spells } \\
\text { per } \\
\text { person }\end{array}$ & Index & $\begin{array}{l}\text { Days } \\
\text { per } \\
\text { spell }\end{array}$ & Index \\
\hline 1980 & $\begin{array}{ll}B & 1 \\
G & 1 \\
N & 1\end{array}$ & $\begin{array}{r}671 \\
1737 \\
1219\end{array}$ & $\begin{array}{l}5.9 \\
7.4 \\
6.4\end{array}$ & $\begin{array}{l}100 \\
150 \\
108\end{array}$ & $\begin{array}{l}1.42 \\
1.85 \\
1.97\end{array}$ & $\begin{array}{l}100 \\
130 \\
139\end{array}$ & $\begin{array}{l}14.4 \\
13.9 \\
10.8\end{array}$ & $\begin{array}{r}100 \\
97 \\
75\end{array}$ \\
\hline 1981 & $\begin{array}{ll}B & 1 \\
G & 1 \\
N & 1\end{array}$ & $\begin{array}{r}630 \\
1705 \\
1246\end{array}$ & $\begin{array}{l}5.1 \\
7.2 \\
6.1\end{array}$ & $\begin{array}{l}100 \\
141 \\
120\end{array}$ & $\begin{array}{l}1.28 \\
1.73 \\
1.93\end{array}$ & $\begin{array}{l}100 \\
135 \\
151\end{array}$ & $\begin{array}{l}15.0 \\
14.2 \\
11.7\end{array}$ & $\begin{array}{r}100 \\
95 \\
78\end{array}$ \\
\hline $\begin{array}{c}1980 \\
+ \\
1981\end{array}$ & $\begin{array}{ll}\text { B } & 1 \\
G & 1 \\
\text { N } & 1\end{array}$ & $\begin{array}{r}651 \\
1721 \\
1233\end{array}$ & $\begin{array}{l}5.5 \\
7.3 \\
6.2\end{array}$ & $\begin{array}{l}100 \\
133 \\
113\end{array}$ & $\begin{array}{l}1.35 \\
1.79 \\
1.95\end{array}$ & $\begin{array}{l}100 \\
133 \\
144\end{array}$ & $\begin{array}{l}14.7 \\
14.0 \\
11.3\end{array}$ & $\begin{array}{r}100 \\
95 \\
77\end{array}$ \\
\hline
\end{tabular}

Employees of the latter firm take 40-50\% more spells than their Belgian colleagues. An opposite ranking of firms can be observed on our third indicator. The mean length of spells in N1 is approximately three days shorter than in B1 and G1. Although in severity and frequency rates decreased in the second observation year, the ranking of firms found for each measure is not affected and seems quite stable. Therefore, we will continue this analysis by using only mean rates for the entire period of observation.

Table 5.3.3 Average annual severity and frequency rates by duration class in Case 1 (1980 and 1981)

\begin{tabular}{|c|c|c|c|c|c|c|c|c|c|c|}
\hline \multirow[b]{2}{*}{$\begin{array}{l}\text { Mea- } \\
\text { sure }\end{array}$} & \multirow[b]{2}{*}{ Firm } & \multirow[b]{2}{*}{$\begin{array}{c}\text { No.of } \\
\text { persons }\end{array}$} & \multicolumn{8}{|c|}{ Spells lasting } \\
\hline & & & $\begin{array}{l}1-7 \\
\text { days }\end{array}$ & Index & $\begin{array}{l}8-42 \\
\text { days }\end{array}$ & Index & $\begin{array}{l}\text { 43-365 } \\
\text { days }\end{array}$ & Index & Total & Index \\
\hline Perc. & B 1 & 651 & 1.2 & 100 & 1.9 & 100 & 2.6 & 100 & 5.5 & 100 \\
\hline days & G 1 & 1721 & 0.9 & 75 & 3.6 & 189 & 2.8 & 108 & 7.3 & 133 \\
\hline p.person & N 1 & 1233 & 1.4 & 117 & 1.7 & 89 & 3.0 & 115 & 6.2 & 113 \\
\hline Spells & B 1 & 651 & 0.86 & 100 & 0.40 & 100 & 0.08 & 100 & 1.35 & 100 \\
\hline per & G 1 & 1721 & 0.97 & 113 & 0.71 & 178 & 0.11 & 138 & 1.79 & 133 \\
\hline person & N 1 & 1233 & 1.44 & 167 & 0.41 & 103 & 0.10 & 125 & 1.95 & 144 \\
\hline
\end{tabular}


As Table 5.3.3 indicates the highest severity rates, observed for G1, are shown to be primarily due to spells lasting 1-6 weeks (surplus: $80 \%$ ). For short term absences and spells lasting over six weeks the highest severity rates are found among the Dutch population. Moreover, in this firm the frequency of 1-7 days spells is $50-60 \%$ higher than in G1 and B1, respectively. Rates for long lasting sickness absence (over six weeks) are particularly low in B1. These first findings indicate that for both years of observation the lowest severity and frequency rates have been noted in B1 personnel. G1 employees show the highest severity rates, whereas the highest frequency rates were measured in N1.

\subsubsection{Confounding factors}

From Section 5.3.1 we know that female, elderly and manual workers are not equally distributed within the cluster, so a more specific comparison may be appropriate. We will examine whether the pattern of findings changes when sickness absence rates are being compared across more homogeneous subgroups.

Figure 5.3.1 Average age- specific severity and frequency rates in Case 1 (1980 and 1981)
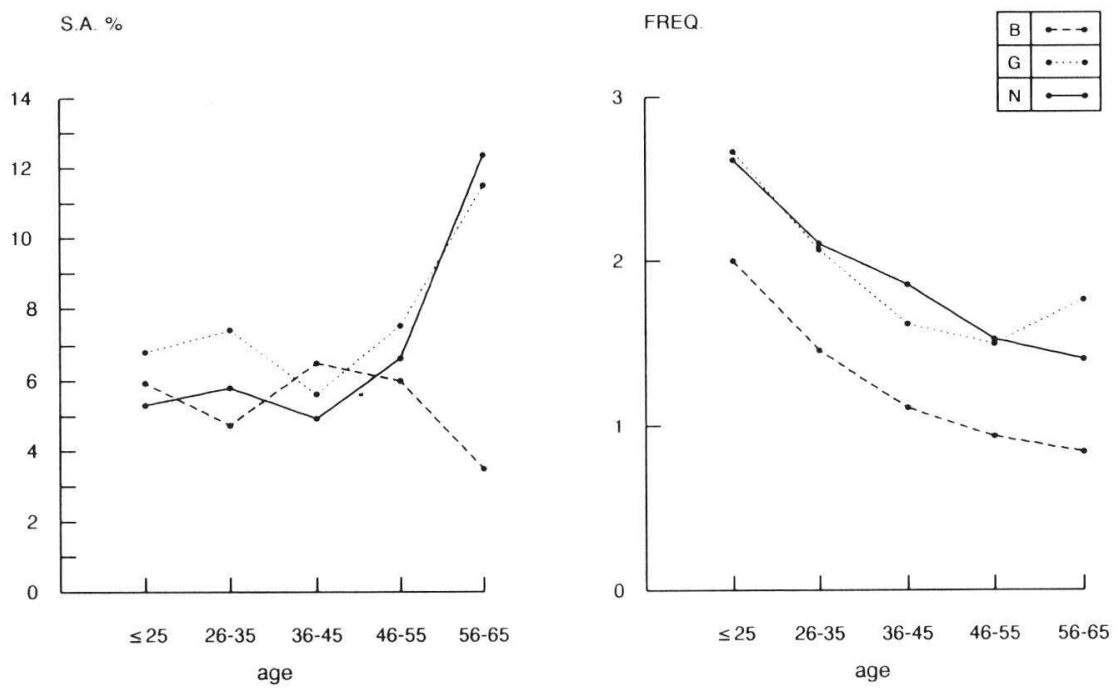

Firstly, we may note that the different age structure in D1 affects our conclusions (cf. Fig. 5.3.1). The rank order observed in severity rates (B1: lowest; G1: highest) is now only reflected in two age categories (namely, 26-35 years and 46-55 years). Various rank orders can be found in other categories. But frequency rates show more consistency: in each age group B1-personnel takes least spells, whereas in G1 and N1 populations markedly higher frequencies are observed. Figures on average spell length (not presented) in four of five age groups indicate B1 having the longest and N1 showing the shortest spell duration. 
In none of the firms the usual relationship was found between age (-group) and severity rates: In B1 increasing age seems to have no effect on severity rates at all. The extreme low figure in the highest age group might, however, be due to its small number of persons $(N=35)$. The well-known inverse relationship between age and spell frequency is largely confirmed and also the length of spells increases with rising age.

Table 5.3.4 Average annual sickness absence rates by sex and occupational status in Case 1 (1980 and 1981)

\begin{tabular}{|c|c|c|c|c|c|c|c|c|}
\hline Year & Firm & $\begin{array}{l}\text { No. of } \\
\text { persons }\end{array}$ & $\begin{array}{l}\% \text { Days } \\
\text { per } \\
\text { person }\end{array}$ & Index & $\begin{array}{l}\text { Spells } \\
\text { per } \\
\text { person }\end{array}$ & Index & $\begin{array}{l}\text { Days } \\
\text { per } \\
\text { spell }\end{array}$ & Index \\
\hline Male & $\begin{array}{l}\text { B } 1 \\
\text { G } 1 \\
\text { N } 1\end{array}$ & $\begin{array}{r}538 \\
1534 \\
1049\end{array}$ & $\begin{array}{l}5.4 \\
7.3 \\
6.2\end{array}$ & $\begin{array}{l}100 \\
135 \\
115\end{array}$ & $\begin{array}{l}1.33 \\
1.74 \\
1.83\end{array}$ & $\begin{array}{l}100 \\
131 \\
138\end{array}$ & $\begin{array}{l}14.3 \\
14.3 \\
11.9\end{array}$ & $\begin{array}{r}100 \\
100 \\
83\end{array}$ \\
\hline Female & $\begin{array}{l}\text { B } 1 \\
\text { G } 1 \\
\text { N } 1\end{array}$ & $\begin{array}{l}114 \\
186 \\
187\end{array}$ & $\begin{array}{l}6.6 \\
7.4 \\
6.5\end{array}$ & $\begin{array}{r}100 \\
112 \\
98\end{array}$ & $\begin{array}{l}1.47 \\
2.26 \\
2.55\end{array}$ & $\begin{array}{l}100 \\
154 \\
173\end{array}$ & $\begin{array}{r}16.6 \\
12.0 \\
8.5\end{array}$ & $\begin{array}{r}100 \\
72 \\
51\end{array}$ \\
\hline Staff & $\begin{array}{l}\text { B } 1 \\
\text { G } 1 \\
\text { N } 1\end{array}$ & $\begin{array}{r}238 \\
456 \\
1016\end{array}$ & $\begin{array}{l}2.8 \\
5.6 \\
5.1\end{array}$ & $\begin{array}{l}100 \\
200 \\
182\end{array}$ & $\begin{array}{l}0.91 \\
1.66 \\
1.72\end{array}$ & $\begin{array}{l}100 \\
182 \\
189\end{array}$ & $\begin{array}{l}10.7 \\
11.5 \\
10.7\end{array}$ & $\begin{array}{l}100 \\
107 \\
100\end{array}$ \\
\hline Manual & $\begin{array}{l}\text { B } 1 \\
\text { G } 1 \\
\text { N } 1\end{array}$ & $\begin{array}{r}414 \\
1265 \\
218\end{array}$ & $\begin{array}{r}7.2 \\
7.9 \\
11.3\end{array}$ & $\begin{array}{l}100 \\
110 \\
157\end{array}$ & $\begin{array}{l}1.61 \\
1.84 \\
3.00\end{array}$ & $\begin{array}{l}100 \\
142 \\
186\end{array}$ & $\begin{array}{l}16.0 \\
14.9 \\
12.8\end{array}$ & $\begin{array}{r}100 \\
93 \\
80\end{array}$ \\
\hline
\end{tabular}

The proportions of male and female employees also affect our findings. Differences between Belgian and Dutch female severity rates have diminished (cf. Table 5.3.4). But for spell frequency the range of differences between B1, G1 and N1 has increased. Finally, it becomes clear, that cross-organizational differences in spell duration predominantly hold for female workers; the average duration of male absences is converging.

In this cluster associations of sex with sickness absence measures do not entirely fit with conclusions from literature. Only in B1 do female employees have the expected substantially higher severity rates than males. But in each firm sex-specific frequency rates vary in accordance with findings from other studies: female workers take more absences per person than males.

Figures in Table 5.3.4 also reveal that the different occupational distribution in $\mathrm{N} 1$ seriously affects its sickness absence rates. N1 staff absence is very close to the (highest) German level, being $80 \%$ over Belgian figures. For manual workers the ranking found so far has changed considerably: Dutch manual workers show about $50 \%$ more days lost due to sickness than their collegues in B1 and G1. Different ranks in manual and staff as well as the exceptional proportion of the latter in the N1 population indicate that sickness absence rates for entire N1 have been biased downward. Occupation-specific spell frequencies reflect the familiar pattern: B1 employees, whether staff or manual have the lowest number of sickness absence spells per person, whereas the highest rates can be observed for both categories in N1. The range between B1 
and $\mathrm{N} 1$ has increased to approx. 90\% more absences in N1. In all firms average spell duration is nearly the same in staff, but among manual workers the familiar rank order can be observed again. Furthermore, Table 5.3.4 demonstrates an identical assocation between occupational status and sickness absence throughout the cluster.

This second part of the analysis indicates that the lowest position of B1 regarding sickness absence rates is consistently unaffected by confounding factors. Differences in age structure and occupational composition partly account for the rates observed in G1 and N1. Sickness absence in G1 is biased upward by the relatively older population, whereas absence figures for N1 are biased downward due to a large proportion of staff employees.

\subsubsection{Further conclusions from standardized figures}

Our next step presents an over-all comparison making allowance for effects of different distributions of major population characteristics. To this end a direct standardization has been applied (cf. Section 5.2) allowing comparisons across firms and adjusting rates for differences in population structure.

Table 5.3.5 Average annual severity and frequency rates standardized for sex, age and occupational status in Case 1 (1980 and 1981)

\begin{tabular}{|c|c|c|c|c|c|c|c|c|c|c|}
\hline \multirow[b]{2}{*}{$\begin{array}{l}\text { Mea- } \\
\text { sure }\end{array}$} & \multirow[b]{2}{*}{ Firm } & \multirow[b]{2}{*}{$\begin{array}{l}\text { No. of } \\
\text { persons }\end{array}$} & \multicolumn{7}{|c|}{ Spells lasting } & \multirow[b]{2}{*}{ Index } \\
\hline & & & $\begin{array}{l}1-7 \\
\text { days }\end{array}$ & Index & $\begin{array}{l}8-42 \\
\text { days }\end{array}$ & Index & $\begin{array}{l}43-365 \\
\text { days }\end{array}$ & Index & Total & \\
\hline$\%$ Days & B 1 & 651 & 1.0 & 100 & 1.7 & 100 & 2.6 & 100 & 5.3 & 100 \\
\hline & G 1 & 1720 & 1.0 & 100 & 3.1 & 182 & 2.5 & 96 & 6.6 & 125 \\
\hline person & N 1 & 1233 & 1.7 & 170 & 2.7 & 159 & 3.9 & 150 & 8.3 & 157 \\
\hline Spells & B 1 & 651 & 0.75 & 100 & 0.36 & 100 & 0.07 & 100 & 1.18 & 100 \\
\hline per & G 1 & 1720 & 1.05 & 140 & 0.63 & 175 & 0.10 & 143 & 1.76 & 149 \\
\hline person & N 1 & 1233 & 1.54 & 205 & 0.63 & 175 & 0.13 & 186 & 2.30 & 195 \\
\hline
\end{tabular}

Now for both measures an identical rank order is observed: B1 shows the lowest sickness absence rates in (nearly) all duration classes, G1 personnel clearly taking an intermediate position, whereas the highest figures are found in N1 personnel. The range of differences has increased: in N1 employees twice as many brief spells are observed, compared with the lowest scoring firm in this cluster, accounting for a $70 \%$ higher percentage of day lost. About $75 \%$ more medium-term absences are taken in G1 and N1, producing the highest sickness absence percentage in G1. Finally, in employees from G1 and N1, respectively $50-90 \%$ more spells lasting over six weeks are noted.

Summarising our findings we may conclude that sickness absence has a low profile in the Belgian firm which consistently shows the lowest frequency and severity rates. For the German firm high rates for spells lasting one to six weeks seem characteristic, rates for short term absences are quite similar to that in B1. Finally, for the Dutch firm many brief spells and high levels of long term sickness absence are obvious. Cross-national differences were further 
demonstrated to be stable and quite consistent; they appear smaller among female and staff employees but sharpened in male and manual personnel. Finally, it came out that severity rates did not for all firms show identical relationships with population characteristics. For frequency rates associations were highly consistent throughout the cluster.

\subsection{Case 2 Margarine Cluster}

\subsubsection{Company characteristics}

All firms in this cluster are associated with a multinational enterprise in the food processing industry. They were established at the beginning of this century and are located in central industrial areas. Their products consist of margarine and semi-manufactured articles for the food industry. The production process operates with identical technology in all firms. Marketing and sales departments are not situated at plant level and are therefore not included in our study. All firms operate the same type of wage system (fixed wages according to collective agreements, without bonus) and are said to give a high degree of job security.

Table 5.4.1 Key figures for Case 2 (1980)

\begin{tabular}{lrrr}
\hline Characteristics & B2 & G2 & N2 \\
\hline Average population size (person years) & 694 & 839 & 823 \\
Percentage of (direct) production workers & 68 & 55 & 56 \\
Percentage of shift workers & 61 & 47 & 55 \\
Mean age (years) & 40 & 44 & 40 \\
Mean seniority (years) & 17 & 18 & 15 \\
Percentage of female employees & 11 & 21 & 9 \\
Percentage of salaried employees & 26 & 34 & 32 \\
Percentage of migrant workers & 3 & 8 & 3 \\
\hline
\end{tabular}

The selection criterion "organizational size" has been satisfied completely (cf. Table 5.4.1). The highly identical economic structure of these firms is emphasized by similar percentages for salaried employees, direct production workers and shift workers. Shift work is being done in a continuous three cycle system. Moreover, in B2 about 30\% of females are on a two shift system. For the entire cluster production is not sensitive to seasonal fluctuations; other special conditions (strikes, unvoluntary work time reductions) were not prevalent in our observation period.

Most resemblances may be observed for B2 and N2. Both have a similar sex ratio and a relative young population, whereas the German firm employs more female workers and more personnel in higher age groups. Belgian females are largely employed in direct production jobs; in G2 and N2 female personnel is mainly working in research/development and clerical jobs. The higher proportion of older workers in G2 has a historical background. In the transformation from a large labor intensive factory towards a modern but smaller plant with automated production methods personnel policy aimed at avoidance of lay-offs and application of re-training for new jobs. B2 and G2 originally had a smaller scale, growth and modernization being realized by employing young entrants. 
Another general characteristic is the low percentage of migrant workers employed. It may be concluded that this cluster is very homogenous, meeting all selection criteria satisfactorily. Regarding population characteristics G2 shows a slightly higher proportion of high-risk groups than other cluster members.

\subsubsection{Initial comparison of sickness absence rates}

At first glance figures for Case 2 show a pattern of differences similar to rates in Case 1 (cf. Table 5.4.2). Severity rates in the Belgian population are the lowest whereas the highest figures are noted for German firms. N2 takes a median position on the cross-organizational scale of severity rates. Over the two year observation period $\mathrm{G} 2$ rates exceed $\mathrm{B} 2$ figures by $70-100 \%$.

Table 5.4.2 Annual sickness absence rates (severity, frequency, average duration) in Case 2 (1980, 1981, 1980 and 1981)

\begin{tabular}{lllllllll}
\hline Year & Firm & $\begin{array}{l}\text { No. of } \\
\text { persons }\end{array}$ & $\begin{array}{l}\text { \% Days } \\
\text { per } \\
\text { person }\end{array}$ & Index & $\begin{array}{l}\text { Spells } \\
\text { per } \\
\text { person }\end{array}$ & Index & $\begin{array}{l}\text { Days } \\
\text { per } \\
\text { spell }\end{array}$ & $\begin{array}{l}\text { Index } \\
1980\end{array}$ \\
\hline & B 2 2 & 694 & 5.3 & 100 & 1.32 & 100 & 13.7 & 100 \\
& N 2 & 823 & 10.5 & 198 & 1.95 & 148 & 18.2 & 133 \\
\hline & B 2 & 638 & 8.8 & 166 & 1.99 & 151 & 16.6 & 121 \\
1981 & G 2 & 831 & 5.4 & 100 & 1.32 & 100 & 13.8 & 100 \\
& N 2 & 856 & 9.1 & 169 & 1.91 & 145 & 18.8 & 136 \\
\hline 1980 & B 2 & 666 & 8.0 & 148 & 2.18 & 165 & 13.4 & 97 \\
+ & G 2 & 834 & 5.3 & 100 & 1.32 & 100 & 13.7 & 100 \\
1981 & N 2 & 840 & 9.8 & 185 & 1.93 & 146 & 18.5 & 135 \\
\hline
\end{tabular}

For spell frequencies another but familiar pattern is represented: least spells of sickness absence per person are taken by B1 employees. Employees in G2 and N2 show about 50\% more spells per person, with highest rates for the latter population. The shortest mean spell duration is found among B1 personnel. Trends are different: rates fall in G2 and N2 but rise slightly in B2. This, however, does not affect the rank orders observed (except in the case of spell duration).

Table 5.4.3 Average annual severity and frequency rates by duration class in Case 2 (1980 and 1981)

\begin{tabular}{|c|c|c|c|c|c|c|c|c|c|c|}
\hline \multirow[b]{2}{*}{$\begin{array}{l}\text { Mea- } \\
\text { sure }\end{array}$} & \multirow[b]{2}{*}{ Firm } & \multirow[b]{2}{*}{$\begin{array}{l}\text { No. of } \\
\text { persons }\end{array}$} & \multicolumn{8}{|c|}{ Spells lasting } \\
\hline & & & $\begin{array}{l}1-7 \\
\text { days }\end{array}$ & Index & $\begin{array}{l}8-42 \\
\text { days }\end{array}$ & Index & $\begin{array}{l}43-365 \\
\text { days }\end{array}$ & Index & Total & Index \\
\hline Perc. & B 2 & 666 & 1.0 & 100 & 1.9 & 100 & 2.4 & 100 & 5.3 & 100 \\
\hline days & G 2 & 834 & 0.8 & 80 & 4.2 & 221 & 4.8 & 200 & 9.8 & 185 \\
\hline p.person & N 2 & 840 & 1.5 & 150 & 3.0 & 158 & 3.9 & 163 & 8.4 & 148 \\
\hline Spells & B 2 & 666 & 0.80 & 100 & 0.42 & 100 & 0.09 & 100 & 1.32 & 100 \\
\hline per & G 2 & 834 & 1.01 & 126 & 0.77 & 183 & 0.15 & 167 & 1.93 & 146 \\
\hline person & N 1 & 840 & 1.28 & 160 & 0.67 & 160 & 0.14 & 156 & 2.09 & 158 \\
\hline
\end{tabular}


Table 5.4 .3 clarifies our conclusions considerably. For spells lasting up to seven days, the highest severity and frequency rates are observed in the N2 population. G2 has an even lower percentage of days lost for this spell category than B2. But for medium and long term sickness absence the highest rates are found in the $\mathrm{G} 2$ workforce. In fact, frequency rates in the Dutch population are very close. It may be concluded that (again) employees in the Belgian firms have the lowest sickness absence rates. Both the number of spells per person and the percentage of days lost are considerably lower than in the rest of the cluster. On the contrary, highest spell frequency rates have been noted in N2, being mainly due to the highest number of brief absences per person. In both other duration classes the G2 population shows highest rates.

\subsubsection{Minor effects of confounding factors}

As the firms in this cluster resemble each other in many respects it may be expected that controlling for major determinants of sickness absence will only yield small changes in our conclusions. Figure 5.4.1 indicates higher severity rates for G2 in all age categories, with an exception for those aged 46-55. Furthermore, in three age groups the highest spell frequencies are noted among Dutch employees. For the youngest and oldest categories G2 personnel shows highest frequencies again.

Figure 5.4.1 Average age-specific severity and frequency rates in Case 2 (1980 and 1981)
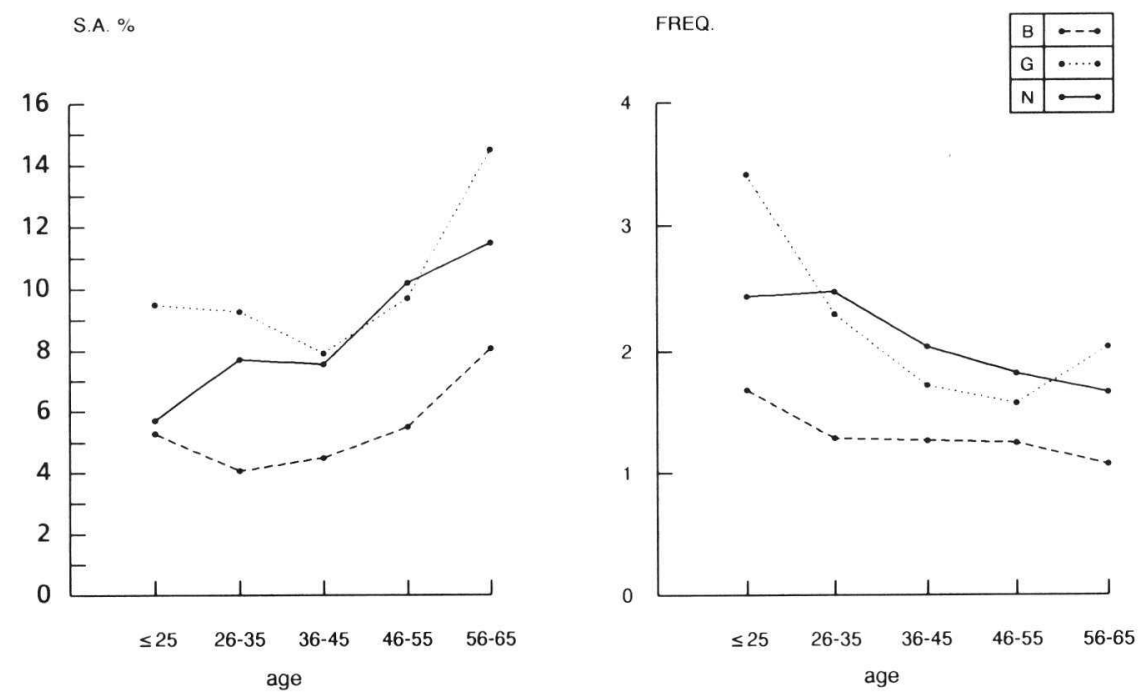

More remarkable is the observation that both B2 and G2 employees do not show a positive relationship between age (group) and percentage days lost due to sickness. Youngest employees show remarkable high rates, next groups 
have lower rates, whereas for the highest age group most days are lost (Ushaped curve). Nevertheless, age-specific severity rates in N1 confirm the (positive) association know from literature.

For all firms frequency rates convincingly demonstrate the relationship expected. Generally speaking, the number of spells per person decreases with rising age (only G2 shows an opposite pattern for the highest age group).

Table 5.4.4 Average annual sickness absence rates by sex and occupational status in Case 2 (1980 and 1981)

\begin{tabular}{|c|c|c|c|c|c|c|c|c|}
\hline Year & Firm & $\begin{array}{l}\text { No. of } \\
\text { persons }\end{array}$ & $\begin{array}{l}\% \text { Days } \\
\text { per } \\
\text { person }\end{array}$ & Index & $\begin{array}{l}\text { Spells } \\
\text { per } \\
\text { person }\end{array}$ & Index & $\begin{array}{l}\text { Days } \\
\text { per } \\
\text { spell }\end{array}$ & Index \\
\hline Male & $\begin{array}{ll}\text { B } & 2 \\
\text { G } & 2 \\
\text { N } & 2\end{array}$ & $\begin{array}{l}593 \\
658 \\
745\end{array}$ & $\begin{array}{l}5.0 \\
9.9 \\
8.3\end{array}$ & $\begin{array}{l}100 \\
198 \\
166\end{array}$ & $\begin{array}{l}1.22 \\
1.88 \\
2.03\end{array}$ & $\begin{array}{l}100 \\
154 \\
166\end{array}$ & $\begin{array}{l}14.2 \\
19.0 \\
15.3\end{array}$ & $\begin{array}{l}100 \\
134 \\
108\end{array}$ \\
\hline Female & $\begin{array}{ll}B & 2 \\
\text { G } & 2 \\
\text { N } & 2\end{array}$ & $\begin{array}{r}74 \\
178 \\
76\end{array}$ & $\begin{array}{l}7.7 \\
9.3 \\
9.5\end{array}$ & $\begin{array}{l}100 \\
121 \\
123\end{array}$ & $\begin{array}{l}2.10 \\
2.11 \\
2.97\end{array}$ & $\begin{array}{l}100 \\
100 \\
141\end{array}$ & $\begin{array}{l}11.6 \\
16.6 \\
10.4\end{array}$ & $\begin{array}{r}100 \\
143 \\
90\end{array}$ \\
\hline Staff & $\begin{array}{ll}B & 2 \\
G & 2 \\
N & 2\end{array}$ & $\begin{array}{l}176 \\
281 \\
259\end{array}$ & $\begin{array}{l}3.6 \\
5.2 \\
5.8\end{array}$ & $\begin{array}{l}100 \\
144 \\
161\end{array}$ & $\begin{array}{l}1.04 \\
1.63 \\
1.74\end{array}$ & $\begin{array}{l}100 \\
157 \\
167\end{array}$ & $\begin{array}{l}12.0 \\
11.9 \\
11.6\end{array}$ & $\begin{array}{r}100 \\
99 \\
97\end{array}$ \\
\hline Manual & $\begin{array}{ll}\text { B } & 2 \\
\text { G } & 2 \\
\text { N } & 2\end{array}$ & $\begin{array}{l}490 \\
554 \\
561\end{array}$ & $\begin{array}{r}5.9 \\
12.1 \\
9.6\end{array}$ & $\begin{array}{l}100 \\
205 \\
163\end{array}$ & $\begin{array}{l}1.42 \\
2.09 \\
2.29\end{array}$ & $\begin{array}{l}100 \\
147 \\
161\end{array}$ & $\begin{array}{l}14.3 \\
21.3 \\
15.9\end{array}$ & $\begin{array}{l}100 \\
149 \\
111\end{array}$ \\
\hline
\end{tabular}

Sex distribution differences do not affect our conclusions substantially (cf. Table 5.4.4). The "familiar" ranking of firms may be observed both in male and female employees, albeit cross-organizational differences have increased in male employees and diminished in female workers. A minor change is apparent in spell duration rates. Sickness absences in female Dutch employees have the shortest spell length.

As previously indicated all firms have similar occupational structures. Notwithstanding, this characteristic in part affects our conclusions. The highest severity rates observed in G2 are attibutable to its manual personnel: staff employees show smaller differences. This variable, however, does not change the rank order observed in frequency rates. Average duration figures hardly show cross-organizational differences among staff employees. But for manual workers in G2 absences last about five till seven days longer than in N2 and $\mathrm{B} 2$, respectively.

Finally, in all firms the same type of associations is being found. In each firm in the manual sub-category $60-130 \%$ more days are lost due to

sickness, whereas their frequency rates exceed those in staff by about $30 \%$. Spells in manual employees consistently last longer (two till nine days) than absences found in staff personnel. 


\subsubsection{Findings from standardized sickness absence rates}

Our findings indicate that cross-organizational differences observed may only partially be due to specific population structures in this cluster. Only for agespecific rates a shift in rank position between G2 and N2 is observed, whereas controlling for sex and occupational status reduces differences between these firms for certain sub-categories (female, staff). Therefore, it may be expected that standardization will not produce substantial new insights.

A comparison of figures set out in Table 5.4 .5 with unstandardized rates (cf. Table 5.4.3) confirms the minor degree of these corrections. So the second case study yields results which are slightly different from those in Case 1.

Table 5.4.5 Average annual severity and frequency rates standardized for sex, age and occupational status in Case 2 (1980 and 1981)

\begin{tabular}{|c|c|c|c|c|c|c|c|c|c|c|}
\hline \multirow[b]{2}{*}{$\begin{array}{l}\text { Mea- } \\
\text { sure }\end{array}$} & \multirow[b]{2}{*}{ Firm } & \multirow[b]{2}{*}{$\begin{array}{l}\text { No. of } \\
\text { persons }\end{array}$} & \multicolumn{8}{|c|}{ Spells lasting } \\
\hline & & & $\begin{array}{l}1-7 \\
\text { days }\end{array}$ & Index & $\begin{array}{l}8-42 \\
\text { days }\end{array}$ & Index & $\begin{array}{l}\text { 43-365 } \\
\text { days }\end{array}$ & Index & Total & Index \\
\hline$\%$ Days & B 2 & 666 & 1.0 & 100 & 1.8 & 100 & 2.4 & 100 & 5.2 & 100 \\
\hline & G 2 & 835 & 0.9 & 90 & 4.6 & 256 & 4.5 & 188 & 10.0 & 192 \\
\hline person & N 2 & 820 & 1.5 & 150 & 3.1 & 172 & 4.2 & 175 & 8.7 & 167 \\
\hline Spells & B 2 & 666 & 0.80 & 100 & 0.40 & 100 & 0.09 & 100 & 1.30 & 100 \\
\hline per & G 2 & 835 & 1.10 & 138 & 0.84 & 210 & 0.15 & 167 & 2.09 & 161 \\
\hline person & N 2 & 820 & 1.25 & 156 & 0.68 & 170 & 0.15 & 167 & 2.08 & 160 \\
\hline
\end{tabular}

Again the Belgian firm systematically shows the lowest severity and frequency rates. Dutch and German employees take 60\% more spells, producing most days lost in the German firm. For brief spells the Dutch personnel once more has a higher rank than the rest of the cluster. Medium term absences are remarkably high in the German firm, whereas both in German and Dutch employees the highest rates are noted for long term sickness absence.

Standardized rates merely show a dichotomy with the Belgian firm on the one hand showing lowest rates and the other two with highest sickness absence on the other. Furthermore, in this cluster mostly identical associations of absence measures with population characteristics have been observed across firms. Again in the Belgian and German firm a somewhat unusual relationship with age for percentage days lost was found (U-shaped curve). The cluster frequency rates, however, show an identical association with this variable throughout. Finally in each firm comparisons between specific occupational groups showed associations well-known from literature.

\subsection{Case 3 Frozen Food Cluster}

\subsubsection{Main characteristics of this cluster}

In the early stages of this project it became clear that much energy was to be spent on Cluster 3. The more or less satisfying outcome of acquisition and selection activities is reflected in Table 5.5.1. The cluster comprises three firms 
producing ice cream or conserved food from agricultural raw material for different sectors of the food market.

Despite these differences the type of product and production process accounts for similar unfavourable physical working conditions (e.g. low temperatures, humidity). All firms, being part of an international company, have their location in rural areas, providing short transport lines for raw material. Marketing and sales activities are concentrated on (a higher) division level and, therefore, stay out of sight in this study. All firms apply a wage system based on collective agreements, without any individual productivity-oriented bonus system.

Table 5.5.1 Key figures for Case 3 (1980)

\begin{tabular}{lrrr}
\hline Characteristics & B3 & G3 & N3 \\
\hline Average population size (person years) & 299 & 1195 & 663 \\
Percentage of (direct) production workers & 73 & 66 & 73 \\
Percentage of shift workers & 82 & 39 & 40 \\
Mean age (years) & 37 & 11 & 16 \\
Mean seniority (years) & 17 & 52 & 8 \\
Percentage of female employees & 38 & 17 & 21 \\
Percentage of salaried employees & 17 & 26 & 10 \\
Percentage of migrant workers & 2 & & \\
\hline
\end{tabular}

* no data available

In this cluster the organizational size varies considerably: it ranges from about 300 to 1200 persons which might seriously affect the interpretation of ourfindings. Furthermore, differences should be considered regarding the effects of seasonal fluctuations or bad economic prospects on the size and composition of the work force. In B3 production peaks are concentrated in spring and summer; consequently the work force is enlarged with over 100 full time female workers on a temporary contract basis. Generally for male production workers a three cycle shift is operated whereas female employees are doing two cycle shifts. During the lull in production, the firm population is reduced by temporary unemployment for some categories of personnel. For G1 flexibility in personnel policy consists of contracting over 200 persons during the "cropping period". Production personnel is working in normal day shift and on two cycle shifts. After years of modernization and growth the Dutch firm was facing a structural decrease in production in 1981. Job uncertainty, rumours on lay offs and a few months of work time reduction accounted for a dramatic fall in sickness absence (from 12 - 7\% within two months). The same type of shift system is undertaken as in G1.

It may be concluded, that differing socio-economic conditions considerably affect the comparability of firms in Case 3. But the composition of the populations of employees shows less differences. The Dutch firm employs an exceptional low proportion of female employees which mainly have clerical jobs. The work forces in all firms further have quite a similar structure (as indicated by mean age and percentages of salaried employees, or production workers). Only the proportion of migrant workers varies considerably, ranging from 2 (B3) to 26 (G3) percent. 


\subsubsection{Plant-level comparisons of sickness absence}

At first sight figures for Case 3 do not show striking new insights compared with the information from previous cases. Indeed in the Belgian firm lowest severity and frequency rates may be noted, whereas highest rates are found in N3 (cf. Table 5.5.2).

Table 5.5.2 Annual sickness absence rates (severity, frequency, average duration) in Case 3 (1980, 1981, 1980 and 1981)

\begin{tabular}{|c|c|c|c|c|c|c|c|c|}
\hline Year & Firm & $\begin{array}{l}\text { No. of } \\
\text { persons }\end{array}$ & $\begin{array}{l}\% \text { Days } \\
\text { per } \\
\text { person }\end{array}$ & Index & $\begin{array}{l}\text { Spells } \\
\text { per } \\
\text { person }\end{array}$ & Index & $\begin{array}{l}\text { Days } \\
\text { per } \\
\text { spell }\end{array}$ & Index \\
\hline \multirow{3}{*}{1980} & B 3 & 299 & 7.6 & 100 & 1.34 & 100 & 19.4 & 100 \\
\hline & G 3 & 1195 & 9.2 & 120 & 1.99 & 149 & 16.8 & 87 \\
\hline & N 3 & 663 & 13.2 & 174 & 2.40 & 179 & 21.2 & 109 \\
\hline \multirow{3}{*}{1981} & B 3 & 313 & 6.9 & 100 & 1.18 & 100 & 21.8 & 100 \\
\hline & G 3 & 1157 & 10.4 & 151 & 2.05 & 174 & 17.7 & 81 \\
\hline & N 3 & 638 & 9.9 & 143 & 1.96 & 166 & 18.3 & 84 \\
\hline 1980 & B 3 & 306 & 7.2 & 100 & 1.26 & 100 & 20.6 & 100 \\
\hline+ & G 3 & 1176 & 9.8 & 136 & 2.02 & 160 & 17.2 & 83 \\
\hline 1981 & N 3 & 651 & 11.6 & 161 & 2.18 & 173 & 19.8 & 96 \\
\hline
\end{tabular}

The highest rank for N3 is not observed for 1981 but data for this year have been highly affected by extraordinary circumstances like unvoluntary work time reduction (cf. Section 5.5.1). Notwithstanding, for the entire observation period an $60 \%$ higher sickness absence percentage is noted compared with B3. In N3 employees took about $70 \%$ more spells per person, closely followed by D3 (showing an excess of 60\%). Figures suggest the shortest spell duration for D3, whereas absences on average last 3-4 days longer in B3 and G3. Not surprisingly, trends in sickness absence differ within this cluster. For G3 a rise is obvious, whereas rates decline in B3, N3 showing the steep fall considered before. For further comparisons data for the entire period may allow conclusions being less sensitive to the particular development in N3 sickness absence.

Table 5.5.3 Average annual severity and frequency rates by durationclass in Case 3 (1980 and 1981)

\begin{tabular}{|c|c|c|c|c|c|c|c|c|c|c|}
\hline \multirow[b]{2}{*}{$\begin{array}{l}\text { Mea- } \\
\text { sure }\end{array}$} & \multirow[b]{2}{*}{ Firm } & \multirow[b]{2}{*}{$\begin{array}{l}\text { No. of } \\
\text { persons }\end{array}$} & \multicolumn{8}{|c|}{ Spells lasting } \\
\hline & & & $\begin{array}{l}1-7 \\
\text { days }\end{array}$ & Index & $\begin{array}{l}8-42 \\
\text { days }\end{array}$ & Index & $\begin{array}{l}43-365 \\
\text { days }\end{array}$ & Index & Total & Index \\
\hline Perc. & B 3 & 306 & 0.8 & 100 & 2.5 & 100 & 3.8 & 100 & 6.4 & 100 \\
\hline days & G 3 & 1176 & 0.9 & 113 & 5.4 & 216 & 3.4 & 89 & 9.8 & 153 \\
\hline p.person & N 3 & 651 & 1.3 & 163 & 3.9 & 156 & 6.3 & 166 & 11.6 & 181 \\
\hline Spells & B 3 & 306 & 0.66 & 100 & 0.47 & 100 & 0.12 & 100 & 1.26 & 100 \\
\hline per & G 3 & 1176 & 0.71 & 108 & 1.17 & 249 & 0.14 & 117 & 2.02 & 160 \\
\hline person & N 3 & 651 & 1.16 & 176 & 0.84 & 179 & 0.19 & 158 & 2.18 & 173 \\
\hline
\end{tabular}

A differentiation between three classes of absences provides conclusions resembling those in previous cases. Rates for brief spells are low for B3 and G3. 
Dutch employees show over $70 \%$ more spells per person in this category, producing about $60 \%$ more days lost than in comparable firms. For German personnel high rates for spells lasting 1-6 weeks are obvious (again). Compared to B3 twice as many spells may be noted and over 100\% extra days were attributable to this category. Finally, about $60 \%$ more long-term spells per person have been measured in $\mathrm{N} 3$, but considerably low figures have been found for $\mathrm{G} 3$.

The pattern of differences observed so far is becoming familiar: for (almost) all duration categories the Belgian firm shows the lowest rates, the German counterpart generally taking an intermediate position. Dutch rates clearly exceed both orders for brief spells and absences over six weeks. The middle rank for G3 is mainly due to its extremely high frequency and severity rates for spells lasting one till six weeks.

\subsubsection{Confounding factors considered}

Our comparison across age-specific sickness absence rates provides no new findings (cf. Figure 5.5.1). For each age group severity rates in N3 are the highest, albeit the range of differences compared with B3 falls with increasing age. An identical pattern of differences is reflected by frequency rates: for the youngest category $125 \%$ more spells are noted, for the older group just $46 \%$ extra spells are observed in N3. Although being on a lower level rates for G3 mainly resemble the Dutch pattern.

Figure 5.5.1 Average age-specific severity and frequency rates in Case 3 (1980 and 1981)
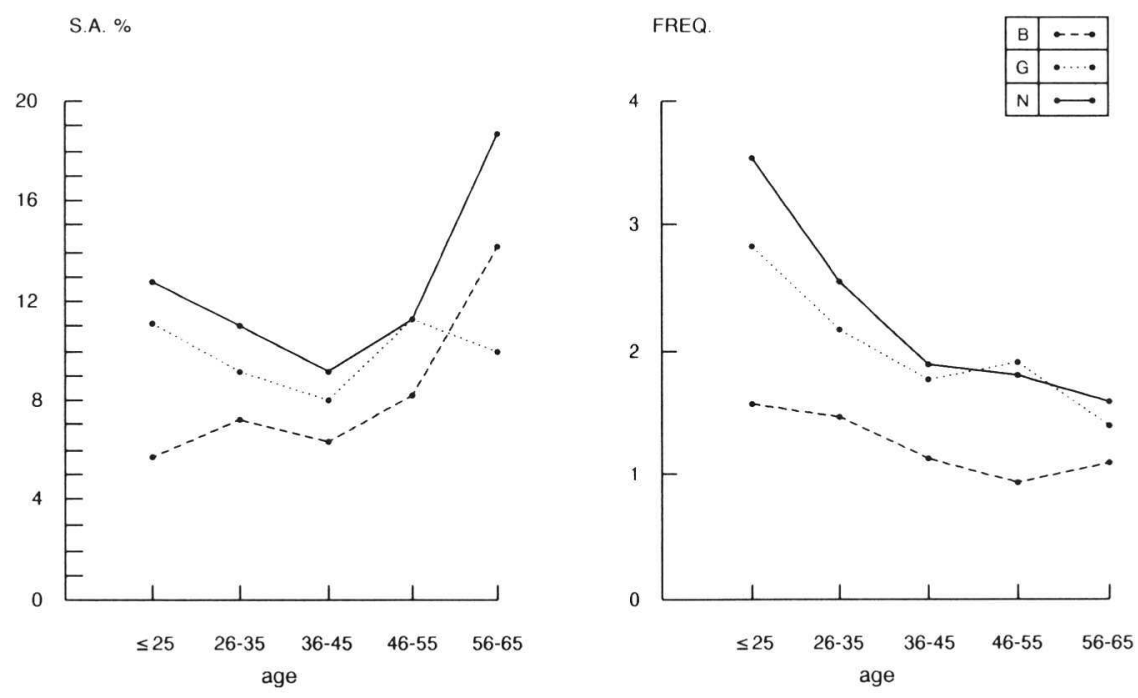
Notwithstanding, rates set out in Figure 5.5.1 still contain something remarkable: only B3 personnel shows a positive association with age (groups) for severity rates. For G3 employees age obviously exerts no effect on percentage days lost, whereas an U-shaped curve is noted for the N3 workforce. Frequencies, however, indicate a more consistent association with age, although two age groups in G3 still show an unusual pattern.

Table 5.5.4 Average annual sickness absence rates (severity, frequency, duration) by sex and occupational status in Case 3 (1980 and 1981)

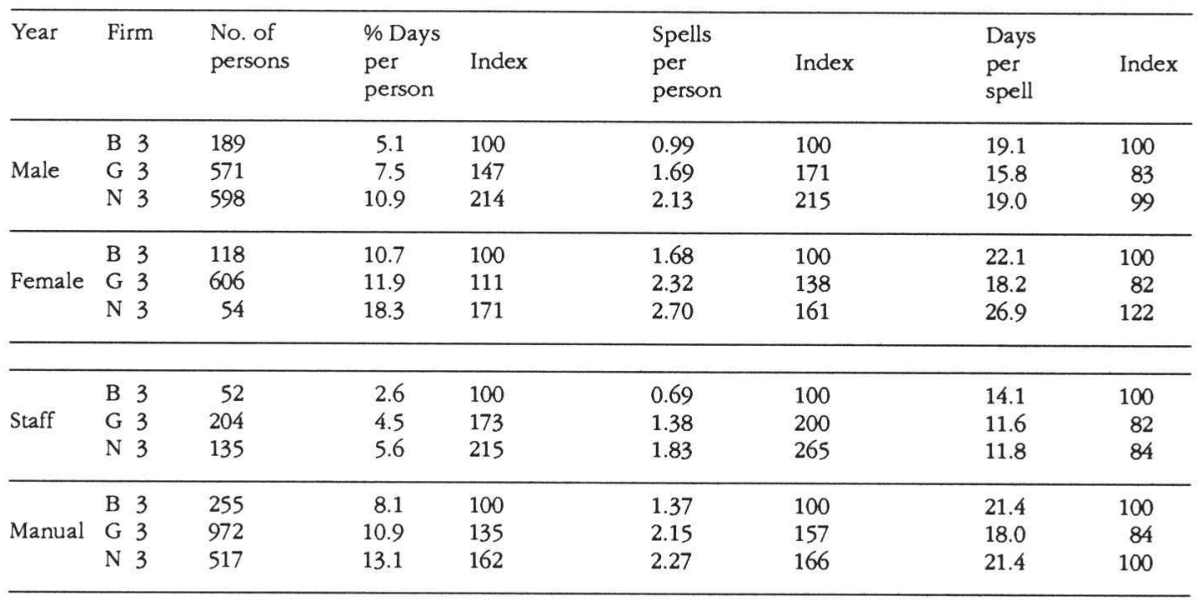

The rank order observed is not affected by the low proportion of female workers in N3 (cf. Table 5.5.4). Differences become more marked showing the highest range in rates in male employees. For female workers the same relationship between firms can be observed but differences are smaller.

Furthermore, figures set out confirm for each firm the association between sex and sickness absence measures: highest severity and frequency rates are found in female employees. Comparing absence rates across occupational categories B3 again shows the largest discrepancies, as manual workers have $100 \%$ more spells than staff employees, accounting for a 200\% higher percentage of sick days. G3 and N3 show smaller but still considerable differences between these personnel categories. This variable does not affect our rank order, but data merely suggests that international differences are smaller among manual workers and larger in staff personnel.

\subsubsection{A review of findings by standardization}

By introducing confounding factors the differences became more marked, which now may be summarized in condensed figures provided by standardization (cf. Table 5.5.5). Minor changes in absolute absence rates show somewhat larger differences between the Belgian and Dutch firm. On the other side the position of the German firm seems to create a dichotomy. Its severity rates are quite low as in the Belgian firm, whereas its frequencies are more comparable with Dutch figures. 
Table 5.5.5 Average annual severity and frequency rates standardized for sex, age and occupational status in Case 3 (1980 and 1981)

\begin{tabular}{|c|c|c|c|c|c|c|c|c|c|c|}
\hline \multirow[b]{2}{*}{$\begin{array}{l}\text { Mea- } \\
\text { sure }\end{array}$} & \multirow[b]{2}{*}{ Firm } & \multirow[b]{2}{*}{$\begin{array}{l}\text { No. of } \\
\text { persons }\end{array}$} & \multicolumn{8}{|c|}{ Spells lasting } \\
\hline & & & $\begin{array}{l}1-7 \\
\text { days }\end{array}$ & Index & $\begin{array}{l}8-42 \\
\text { days }\end{array}$ & Index & $\begin{array}{l}\text { 43-365 } \\
\text { days }\end{array}$ & Index & Total & Index \\
\hline$\%$ Days & B 3 & 306 & 0.7 & 100 & 2.5 & 100 & 4.8 & 100 & 8.1 & 100 \\
\hline per & G 3 & 1176 & 0.9 & 129 & 5.1 & 204 & 3.2 & 67 & 9.1 & 112 \\
\hline person & N 3 & 1301 & 1.2 & 171 & 4.5 & 180 & 8.2 & 171 & 13.9 & 172 \\
\hline Spells & B 3 & 306 & 0.57 & 100 & 0.46 & 100 & 0.14 & 100 & 1.16 & 100 \\
\hline per & G 3 & 1176 & 0.69 & 121 & 1.10 & 239 & 0.13 & 93 & 1.93 & 166 \\
\hline person & N 3 & 1301 & 1.09 & 191 & 0.94 & 204 & 0.27 & 193 & 2.30 & 198 \\
\hline
\end{tabular}

In spite of the inequal socio-economic conditions for personnel during the observation period our main conclusions in this case study are highly similar to those in Case 1 and - to a lesser extent - to those in Case 2. Sickness absence is relatively low in Belgian employees; only for long term absences does the German firm show even lower figures. In Dutch personnel about twice as many spells occurred, providing about $70 \%$ more days lost. Sickness absence in German personnel resembles the Belgian pattern if severity rates are being compared, but frequency rates are closer to the Dutch figures. This unstable position may predominantly be attributed to the extemely high rates for sickness absences lasting 1-6 weeks.

Finally, within this cluster severity and frequency rates showed familiar assocations with sex and occupational status. Age, however, did not consistently show the relationship mostely indicated in literature. In particular severity rates do not systematically rise with increasing age.

\subsection{Case 4 Tin Cluster}

\subsubsection{Description of cluster firms}

As has been described the fourth case study considers a truncated cluster, only allowing a comparison of sickness absence between a Belgian and a Dutch firm. They are very similar, however: both have the same economic activities, performed in a comparable organizational structure. They produce exactly the same articles: light metal packings for food and non-food industries. The production process, consisting of two production lines in each firm, is identical. Differences are observed regarding the shift system: in N4 shift work is done in a three cycle systemn, whereas a small (maintenance) group works in a two cycle shift. B4 operates not only two and three cycle shifts but halfway through our observation period a five cycle shift was introduced for a new production line. For both firms, production is more or less sensitive to seasonal fluctuations. In autumn 1980 they faced a period of involuntary work time reduction (N4) and temporary unemployment (B4). Wage systems do not differ (fixed wages without bonus). These firms are part of an international enterprise and have their location in mainly rural areas. 
Table 5.6.1 Key figures for Case 4 (1980)

\begin{tabular}{lcc}
\hline Characteristics & B4 & N4 \\
\hline Average population size (person years) & 585 & 83 \\
Percentage of (direct) production workers & 56 & 56 \\
Percentage of shift workers & 63 & 75 \\
Mean age (years) & 38 & 37 \\
Mean seniority (years) & 16 & 12 \\
Percentage of female employees & 14 & 4 \\
Percentage of salaried employees & 24 & 47 \\
Percentage of migrant workers & 9 & 33 \\
\hline
\end{tabular}

Both organizational size and production work force composition are quite similar (cf. Table 5.6.1). Substantial differences may be observed regarding the proportion of female workers, N4 showing a remarably low percentage of women employed. The mean age of the work forces is nearly the same but this crude measure obscures the fact that in the B4 population the proportion of very young and very old is higher than in N4 (with an approximately normal distribution of age). Furthermore, the N4 population comprises a higher proportion of salaried employees. Most striking difference is the $33 \%$ migrant workers in N4 work force, with just 9\% in B4. Notwithstanding vis-àvis differences in sickness absence this case study may allow interesting findings as the firms are in many respects comparable, except for certain population characteristics like the percentage of female and migrant workers.

\subsubsection{A direct comparison of firm figures}

The sickness absence rates calculated for 1980 and 1981 show a clear pattern of differences (cf. Table 5.6.2). The percentage of days lost in N4 is about twice as high as in B4, which is due to $50 \%$ more spells per person in the former. Consequently, on average spells in N4 last considerably (about five days) longer than in B4.

Table 5.6.2 Annual sickness absence rates (severity, frequency, average duration) in Case 4 (1980, 1981, 1980 and 1981)

\begin{tabular}{lllllllll}
\hline Year & Firm & $\begin{array}{l}\text { No. of } \\
\text { persons }\end{array}$ & $\begin{array}{l}\text { \% Days } \\
\text { per } \\
\text { person }\end{array}$ & Index & $\begin{array}{l}\text { Spells } \\
\text { per } \\
\text { person }\end{array}$ & Index & $\begin{array}{l}\text { Days } \\
\text { per } \\
\text { spell }\end{array}$ & Index \\
\hline 1980 & B 4 & 585 & 5.8 & 100 & 1.71 & 100 & 13.1 & 100 \\
\hline N 4 & 783 & 12.4 & 214 & 2.48 & 145 & 18.3 & 140 \\
1981 & B 4 & 658 & 5.8 & 100 & 1.48 & 100 & 12.9 & 100 \\
\hline 1980 & B 4 & 765 & 11.4 & 197 & 2.44 & 165 & 18.0 & 140 \\
$+\begin{array}{c}+ \\
1981\end{array}$ & N 4 & 774 & 11.9 & 205 & 1.59 & 100 & 13.0 & 100 \\
\hline
\end{tabular}

Sickness absence is more or less stable throughout our observation period: severity rates decrease for the N4-population whereas in B4 this tendency can 
be observed in its frequency rates. Notwithstanding, the cross-national differences are hardly affected.

Table 5.6.3 Average annual severity and frequency rates by duration class in Case 4 (1980 and 1981)

\begin{tabular}{lllllllllll}
\hline & & \multicolumn{7}{c}{ Spells lasting } \\
\cline { 3 - 10 } $\begin{array}{l}\text { Mea- } \\
\text { sure }\end{array}$ & Firm & $\begin{array}{l}\text { No. of } \\
\text { persons }\end{array}$ & $\begin{array}{l}1-7 \\
\text { days }\end{array}$ & Index & $\begin{array}{l}8-42 \\
\text { days }\end{array}$ & Index & $\begin{array}{l}43-365 \\
\text { days }\end{array}$ & Index & Total & Index \\
\hline $\begin{array}{l}\text { Perc. } \\
\text { days }\end{array}$ & B 4 & 622 & 1.2 & 100 & 2.2 & 100 & 2.3 & 100 & 5.8 & 100 \\
$\begin{array}{l}\text { p.person } \\
\text { N 4 }\end{array}$ & 774 & 1.4 & 117 & 5.6 & 255 & 5.0 & 217 & 11.9 & 205 \\
\hline $\begin{array}{l}\text { Spells } \\
\text { per }\end{array}$ & B 4 & 622 & 0.96 & 100 & 0.44 & 100 & 0.10 & 100 & 1.59 & 100 \\
person & N 4 & 774 & 1.11 & 116 & 1.17 & 266 & 0.19 & 190 & 2.46 & 155 \\
\hline
\end{tabular}

Table 5.6.3 indicates that both firms differ only slightly regarding short term sickness absences. Medium and long term absences account for the differences observed so far. In N4 about 2.5 times more spells of medium term absence are taken than in B4, and for long term absence about twice as many spells can be observed.

Figure 5.6.1 Average age-specific severity and frequency rates in Case 4 (1980 and 1981)
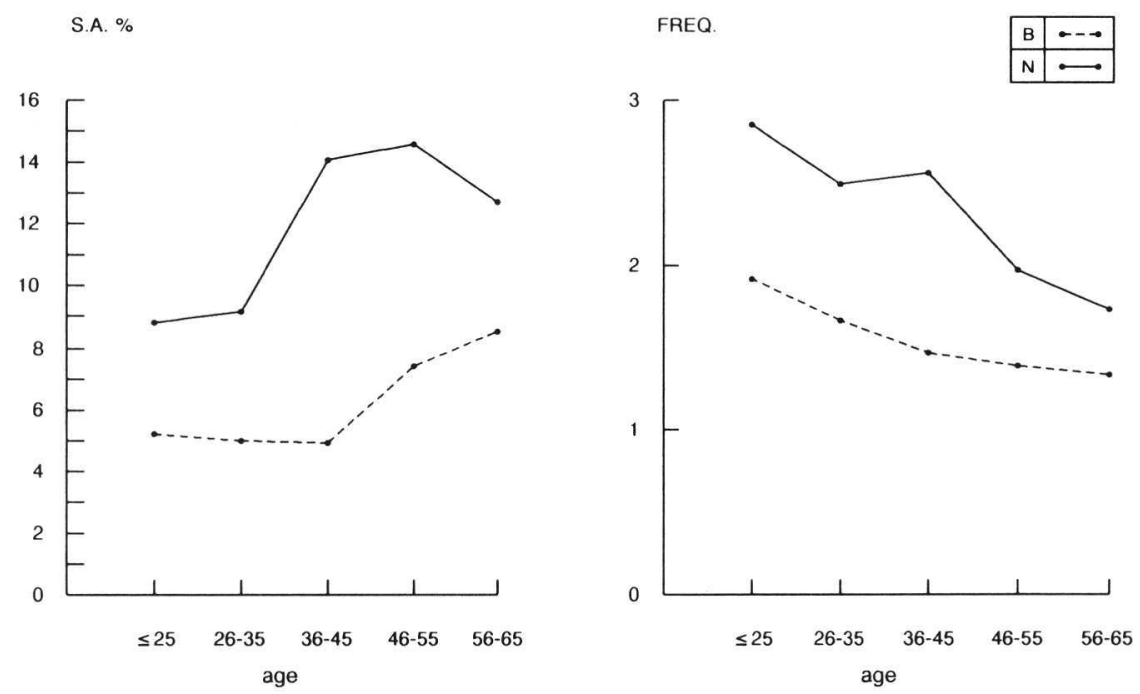

It may be concluded that these findings are in line with the results of our previous case studies. The Dutch firm shows the highest rates, being due to 
substantially more medium and long term sickness absences. The stability and the range of these differences resembles findings in other clusters.

\subsubsection{Confounding factors examined}

From Section 5.6.1 we know that the composition of the work forces is not entirely identical. But more specific comparisons do not lead to new conclusions (cf. Figure 5.6.1).

For each age category N4 shows the highest rates, demonstrating the largest differences for the categories aged 35 up to 55. As may be seen from these figures different associations with age groups have been found for severity rates. Sickness absence does not increase linearly with age: in N4 only the younger employees show this positive assocation, whereas in B4 this very relationship is only observable among the higher age groups. However, both firms show the well known inverse relationship between spell frequency and age.

Table 5.6.4 Average annual sickness absence rates (severity, frequency, duration) by sex and occupational status in Case 4 (1980 and 1981)

\begin{tabular}{|c|c|c|c|c|c|c|c|c|}
\hline \multirow[b]{2}{*}{ Year } & \multirow[b]{2}{*}{ Firm } & \multirow[b]{2}{*}{$\begin{array}{l}\text { No. of } \\
\text { persons }\end{array}$} & \multicolumn{2}{|l|}{ Severity } & \multicolumn{2}{|c|}{ Frequency } & \multicolumn{2}{|c|}{ Duration } \\
\hline & & & $\begin{array}{l}\% \text { Days } \\
\text { per } \\
\text { person }\end{array}$ & Index & $\begin{array}{l}\text { Spells } \\
\text { per } \\
\text { person }\end{array}$ & Index & $\begin{array}{l}\text { Days } \\
\text { per } \\
\text { spell }\end{array}$ & Index \\
\hline \multirow{2}{*}{ Male } & B 4 & 541 & 5.2 & 100 & 1.52 & 100 & 12.6 & 100 \\
\hline & N 4 & 744 & 11.9 & 229 & 2.45 & 161 & 18.2 & 144 \\
\hline \multirow{2}{*}{ Female } & B 4 & 81 & 9.1 & 100 & 2.04 & 100 & 15.2 & 100 \\
\hline & N 4 & 30 & 13.2 & 145 & 2.82 & 138 & 18.2 & 120 \\
\hline \multirow{2}{*}{ Staff } & B 4 & 146 & 3.7 & 100 & 1.22 & 100 & 9.5 & 100 \\
\hline & N 4 & 359 & 8.8 & 238 & 1.96 & 161 & 17.0 & 179 \\
\hline \multirow{2}{*}{ Manual } & B 4 & 476 & 6.4 & 100 & 1.71 & 100 & 13.8 & 100 \\
\hline & N 4 & 416 & 14.6 & 228 & 2.90 & 170 & 18.8 & 136 \\
\hline
\end{tabular}

The considerable differences in sex ratio in Cluster 4 do not seriously affect our findings (cf. Table 5.6.4). Both for male and female employees the N4 population shows the highest rates but differences are smallest among female workers. For instance, among N4 male workers about 130\% more days have been lost due to sickness absence, but female workers in N4 only show 45\% more days lost. Furthermore, Table 5.6.4 indicates that in each firm the same association between sex and absence rates may be observed. Female employees have higher sickness absence rates than their male colleagues. But this familiar relationship is stronger in B4 than in N4, where absence differences between these categories are on a lesser scale. 
Differences in occupational structure do not affect our findings either. Figures for both staff and manual personnel show the same direction and range of differences in sickness absence rates between B4 and N4. Only for spell duration cross-national differences are smaller among manual workers and larger in staff personnel. Not surprisingly, both firms show an identical relationship between occupational status and sickness absence. Sickness absence in manual workers is (about $40-70 \%$ ) higher than in staff personnel, again with an exception for average duration. From this second part of the analysis it may be concluded that controlling for confounding factors will not substantially change our conclusions.

In general in $\mathrm{N} 4$ the sickness absence percentage is twice as high as in B4, which clearly is not due to the specific composition of its work force. (Even controlling for the variable nationality, not presented here, did not affect the direction and range of differences.)

\subsubsection{Standardization and review}

From the foregoing it may be expected that the standardization procedure will not produce substantial shifts in our figures. As Table 5.6.5 indicates, the results merely provide a refinement of our conclusions. Differences become more marked: now the range of differences has increased, both for frequency and severity rates. These corrected data suggest that in the Dutch firm the number of days lost due to sickness absence is about $150 \%$ higher than in the Belgian counterpart. Both medium term and long term absence contribute to this pattern: about $150 \%$ more spells per person in these duration categories may be observed, producing nearly $200 \%$ more days lost, in the Dutch firm.

Table 5.6.5 Average annual severity and frequency rates standardized for sex, age and occupational status in Case 4 (1980 and 1981)

\begin{tabular}{lllllllllll}
\hline & & \multicolumn{7}{c}{ Spells lasting } \\
\cline { 3 - 10 } $\begin{array}{l}\text { Mea- } \\
\text { sure }\end{array}$ & Firm & $\begin{array}{l}\text { No. of } \\
\text { persons }\end{array}$ & $\begin{array}{l}1-7 \\
\text { days }\end{array}$ & Index & $\begin{array}{l}8-42 \\
\text { days }\end{array}$ & Index & $\begin{array}{l}43-365 \\
\text { days }\end{array}$ & Index & Total & Index \\
\hline $\begin{array}{l}\text { \% Days } \\
\text { per } \\
\text { person }\end{array}$ & B 4 & 622 & 1.1 & 100 & 2.0 & 100 & 2.0 & 100 & 5.2 & 100 \\
\hline $\begin{array}{l}\text { Spells } \\
\text { per }\end{array}$ & B 4 & 774 & 1.4 & 127 & 5.9 & 295 & 5.6 & 280 & 12.8 & 246 \\
person & N 4 & 774 & 0.93 & 100 & 0.44 & 100 & 0.09 & 100 & 1.45 & 100 \\
\hline
\end{tabular}

Additionally, it may be noted that the differences observed were stable and not seriously affected by confounding factors like age, sex and occupational status. Accounting for these determinants even sharpened our findings. Finally, also in this cluster severity rates did not show the clear positive association with age we expected from literature; for other variables characteristic relationships with absence rates could be observed throughout the cluster. 


\subsection{Summary}

The basis of our comparison consisted of four clusters from different sectors of industry, namely chemical (paint), food (two clusters: margarine and frozen food) and metal industry (tin). The firms selected showed considerable similarities regarding our three selection criteria applied: type of product, size and location of firms. In the analysis three basic sickness absence rates wereapplied, referring to the severity, frequency and duration of absences. In our comparative strategy firms comprising a cluster were firstly described and compared on major organizational and work force characteristics. Subsequently the magnitude, structure and consistency of sickness absence differences were identified. In order to allow for population differences within each cluster a direct standardization was applied for sex, age and occupational status. This technique obviously sharpened the differences previously observed and produced highly consistent findings. The lowest level of sickness absence was found in the Belgian firms, German employees take a middle rank and Dutch rates were the highest. The differences become most marked for medium-term (1-6 weeks) and long-term absences (lasting 7-52 weeks). 


\section{NOTES}

(1) See Section 4.5. for an exact demarcation of the population under investigation.

(2) Calendar days have been applied as a unit of measurement as not only working days (ar days of benefit payment) but all days of a spell are equal in value when sickness absence is initially defined as a health problem. Moreover, the application of calendar days facilitates the measurement of sickness absence for categories of personnel with irregular working hours, e.g. shift workers (cf. Behrend, 1974, for the application of a comparable rate (percentage) but based on working days as unit of measurement).

(3) As indicated the severity rate includes all absence days observed, whereas the frequency is based on beginning spells and the average duration being calculated from completed spells. Due to more or less large differences between the number of beginning and ending spells in an observation period, our "real" spell length may differ from the estimates one may calculate by dividing severity and frequency rates. Furthermore, to calculate frequency and severity rates the following procedure has been applied. For the frequency rates the spells beginning in an observation year are assigned to the appropriate duration class; those not completed at the end of the observation period are assigned to their class by measuring their duration six weeks after termination of the year. By this procedure all commencing spells can be put into the right class.

The severity rates for the first and second duration class are based on the absence days of a spell in the particular class. The severity rate for the final duration class includes the number of sickness days in the observation period accounted for by spells lasting 43-365 calendar days.

(4) In applying a direct standardization the entire cluster population was chosen as the standard population, to which the observed rates for the specific firm population have been applied. 


\section{CONCLUSIONS FROM}

\section{CASE STUDIES AND ADDITIONAL DATA}

\subsection{An overview of initial case study findings}

The present comparative study of sickness absence in the Netherlands and its neighbouring countries intends to avoid as far as possible the methodological and statistical constraints mentioned in Chapter 4. To that end cross-national differences in level and structure of sickness absence were investigated by relying heavily on performing four case studies, each case consisting of a similar Belgian, German and Dutch firm. In this chapter results from each case study will be discussed and compared regarding the magnitude, type and consistency in sickness absence differences within each cluster. Consistency in findings will add weight to general conclusion to be drawn from these cases. After assessing these differences in sickness absence their nature will be further explored on aggregated data from the national groups. For that part of our central problem that can not be investigated on this material (e.g. as to trends in sickness absence rates) we will use additional data or local investigations.

\subsubsection{Lowest rates in Belgian firms}

For an initial overview of differences observed in each case study basic sickness absence rates (unstandardized) have been set out in Table 6.1. To facilitate comparisons "within" clusters, simple indices instead of absolute rates have been used (Belgian firms being selected as the base of the index). Figures refer to the entire period of investigation, as, with an exception of Case 3 , the rank orders (and ranges of differences) observed in severity and frequency rates were very similar for 1980 and 1981 . The less stable pattern observed in the third cluster is suggested to be due mainly to some extraordinary events in N3 (production stops and work time reduction in 1981; cf. Section 5.5.1). Within two clusters the indicator "Days per spell" showed considerable variation between years, so this duration measure must be used with caution.

Table 6.1 Overview of indexed sickness absence rates in four clusters (1980 and 1981).

\begin{tabular}{|c|c|c|c|c|c|c|c|c|c|c|c|c|}
\hline & \multicolumn{4}{|c|}{$\begin{array}{c}\text { Index } \\
\text { \% Days per person }\end{array}$} & \multicolumn{4}{|c|}{$\begin{array}{c}\text { Index } \\
\text { Spells per person }\end{array}$} & \multicolumn{4}{|c|}{$\begin{array}{c}\text { Index } \\
\text { Days per spell }\end{array}$} \\
\hline & \multicolumn{4}{|c|}{ Cluster } & \multicolumn{4}{|c|}{ Cluster } & \multicolumn{4}{|c|}{ Cluster } \\
\hline & 1 & 2 & 3 & 4 & 1 & 2 & 3 & 4 & 1 & 2 & 3 & 4 \\
\hline B & 100 & 100 & 100 & 100 & 100 & 100 & 100 & 100 & 100 & 100 & 100 & 100 \\
\hline G & 133 & 185 & 136 & - & 133 & 146 & 160 & - & 95 & 135 & 83 & - \\
\hline $\mathrm{N}$ & 113 & 158 & 161 & 205 & 144 & 158 & 173 & 155 & 77 & 109 & 96 & 140 \\
\hline
\end{tabular}


Sickness absence seems to be a minor problem in Belgian firms. They consistently show the lowest severity and frequency rates. The German and Dutch figures are appreciably higher but severity rates do not yet allow a consistent international rank order. In the first and second cluster German firms show the highest rates, whereas in the third and fourth case the highest rates are noted in the Dutch populations. Moreover the range of differences varies considerably.

A more consistent rank order is obvious in frequency rates. The lowest rank is to be attributed to Belgian employees and the highest rank in number of spells is clearly shown by Dutch workers. Their frequency rates are $40-70 \%$ higher than those in Belgian firms. The German absence frequencies resemble the Dutch more than the Belgian level. The average spell duration does not yield consistent findings. For one half of the cases the shortest spell length was observed in Belgian firms, but in the other half the Belgian personnel showed the longest spell duration.

Our findings now may be concentrated in the form of pooled data from three national groups, since they reflect to a large extent the pattern of differences identified in the four separate case studies (cf. Table 6.2.). Here again three duration classes will be applied, namely 1-7 days (short), 8-42 days (medium) and 43-365 days (long-term absences).

Table 6.2 Average annual severity and frequency rates by duration class in the Belgian, German and Dutch group (1980 and 1981).

\begin{tabular}{|c|c|c|c|c|c|c|c|c|c|c|}
\hline \multirow[b]{2}{*}{$\begin{array}{l}\text { Mea- } \\
\text { sure }\end{array}$} & \multirow{2}{*}{\multicolumn{2}{|c|}{$\begin{array}{l}\text { Group No. of } \\
\text { persons }\end{array}$}} & \multicolumn{8}{|c|}{ Spells lasting } \\
\hline & & & $\begin{array}{l}1-7 \\
\text { days }\end{array}$ & Index & $\begin{array}{l}8-42 \\
\text { days }\end{array}$ & Index & $\begin{array}{l}\text { 43-365 } \\
\text { days }\end{array}$ & Index & Total & Index \\
\hline Perc. & B & 2244 & 1.1 & 100 & 2.1 & 100 & 2.6 & 100 & 5.8 & 100 \\
\hline days & G & 3731 & 0.9 & 82 & 4.3 & 205 & 3.4 & 131 & 8.6 & 148 \\
\hline p.person & $\mathrm{N}$ & 3498 & 1.4 & 127 & 3.3 & 157 & 4.3 & 165 & 9.0 & 155 \\
\hline Spells & B & 2244 & 0.86 & 100 & 0.45 & 100 & 0.10 & 100 & 1.40 & 100 \\
\hline per & G & 3731 & 0.90 & 105 & 0.87 & 193 & 0.13 & 130 & 1.89 & 135 \\
\hline person & $\mathrm{N}$ & 3498 & 1.28 & 149 & 0.72 & 160 & 0.15 & 150 & 2.14 & 153 \\
\hline
\end{tabular}

The final two columns show the rates and indices based on this aggregation. They indicate that in the Dutch population about $50 \%$ more days have been lost and 50\% more spells have been taken than in the Belgian group. In German firms sickness absence seems to approach the Dutch pattern.

The differentiation into duration classes reflects a few remarkable differences already observed in our case studies. For sbort term sickness absence, lasting up to seven days, figures straightforwardly demonstrate an approximately $50 \%$ higher incidence in Dutch employees compared to their Belgian collegues. German personnel have the same number of spells as Belgian employees but their percentage days lost is somewhat lower than in the latter group. Rates for sickness absence lasting 8-42 days give quite a different picture. German personnel show the highest frequency and severity rates for this category of 
spells. German figures are extremely high: compared to the lowest (Belgian) group about twice as many spells and days lost can be noted. For this category Dutch rates have an intermediate rank, still exceeding Belgian rates by over $50 \%$. Finally, for long term sickness absence, lasting over six weeks (up to one year) again lowest rates have been found in the Belgian population, whereas $50-60 \%$ higher severity and frequency rates are demonstrated in the Dutch group, German employees showing a medium rank.

We may conclude that the lowest sickness absence rates were noted in the Belgian firms. For comparable German and Dutch firms considerably higher severity and frequency rates have been found, consistently showing the highest frequencies in the Dutch population. Conclusions from severity rates were not unanimous, however. On closer inspection it came out that for short and for long term absences the highest rates have been found in Dutch firms. Sickness absence in German firms may be characterized by their extremely high rates for medium term absences. However, more light can be thrown on these differences when confounding factors have been sufficiently accounted for.

\subsubsection{Accounting for major population differences}

From the description of clusters and separate case studies we know that firms in each cluster showed considerable differences in certain population characteristics. Pooled data in Table 6.3, referring to three "national" sets of firms, summarize the major resemblances and differences.

Table 6.3 Key figures for aggregated cases (three national groups) (1980)

\begin{tabular}{|c|c|c|c|}
\hline Characteristics & B & G & $\mathrm{N}$ \\
\hline Average population size (person years) & 2249 & 3771. & 3488 \\
\hline Paint & 671 & 1737 & 1219 \\
\hline Margarine & 694 & 839 & 823 \\
\hline Frozen Food & 299 & 1195 & 663 \\
\hline Tin & 585 & • & 783 \\
\hline Percentage of (direct) production workers & 62 & $\cdot$ & 49 \\
\hline Percentage of shift workers & 46 & 51 & 47 \\
\hline Mean age (years) & 38 & 42 & 39 \\
\hline Mean seniority (years) & 16 & 11 & 14 \\
\hline Percentage of female employees & 17 & 26 & 10 \\
\hline Percentage of salaried employees & 27 & 25 & 51 \\
\hline Percentage of migrant workers & 4 & 14 & 11 \\
\hline
\end{tabular}

")not calculated, only available for 2 firms.

Firstly, Table 6.3 stresses the variation in organizational size within our selection of firms. The Belgian and Dutch groups have most resemblances e.g. regarding the number of firms, branches, size, mean age and mean seniority. Furthermore, these figures indicate several economic similarities for Belgian and German firms. Both being merely manufacturing industries, they have relatively more manual and production-oriented jobs. Most Dutch firms show a more heterogeneous occupational structure, reflecting the employment of more marketing, sales and clerical staff. Finally, in the light of the distribution of other relevant population characteristics it may be remembered from the 
case studies that German firms have a relatively older workforce and the highest proportion of female and migrant workers. In terms of high-risk groups visà-vis sickness absence Belgian and -in particular- German firms show a more unfavorable distribution than the Dutch firms.

In each case study the effects of major variables like age, sex, occupationial status have been evaluated to ensure that our findings were not biased. Comparison of age specific sickness absence rates indicates that the international rank order is very persistent and little influenced by age (cf. Figure 6.1).

Figure 6.1 Age-specific frequency and severity rates in three national groups (1980 and 1981)
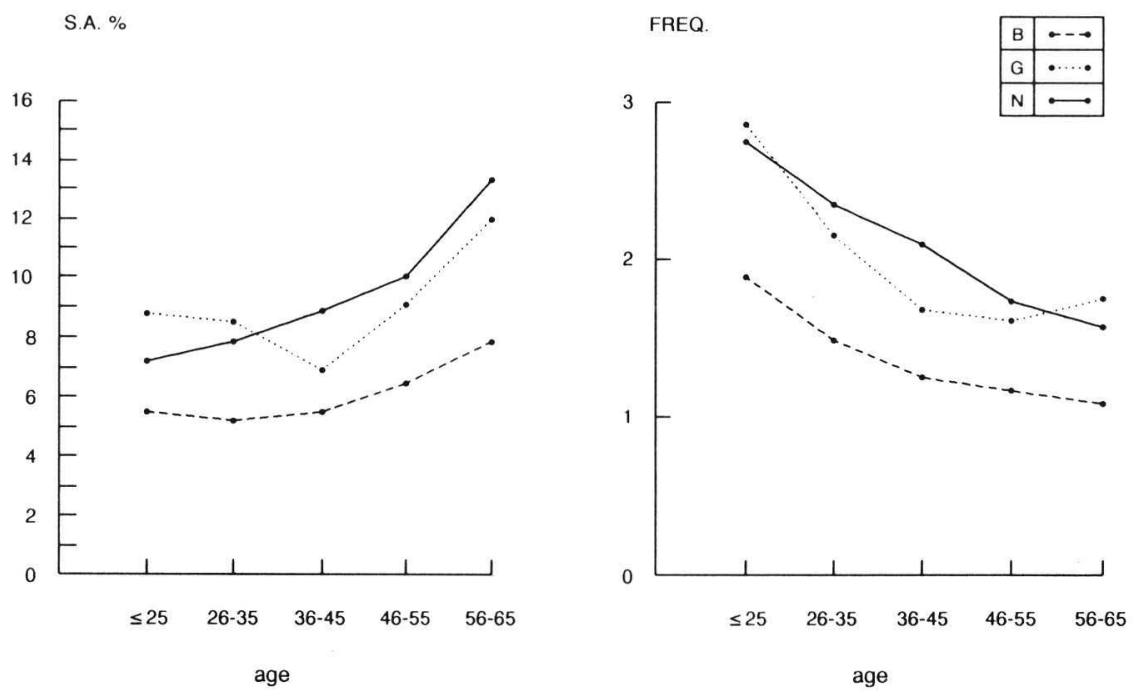

Within each cluster controlling for age did not modify the observed rank order substantially. In each of the five age groups Belgian employees show the lowest values on the absence rates calculated. Except for the youngest groups, the highest rates are again being found among Dutch employees. In general, differences between Belgian and Dutch age groups are obviously quite stable. Furthermore, one national group does not show the association of age with sickness absence usually expected. Both in the Belgian and Dutch group a fairly positive relation has been stated: as age increases also the percentage of sickness absence grows. But in all German firms, an U-shaped curve may be observed, showing the lowest severity rates in the group aged $36-45$ year. For spell frequency, however, in all firms and groups the inverse relation with age was clearly demonstrated. Furthermore, sex-specific absence rates indicate that this variable does not dramatically affect the international ranking observed either (cf. Table 6.4). In the male sub-population cross-national differences in severity and frequency rates are more pronounced than in females. 
Table 6.4 Average annual sickness absence rates by sex and occupational status in three national groups (1980 and 1981)

\begin{tabular}{|c|c|c|c|c|c|c|c|c|}
\hline Year & Firm & $\begin{array}{l}\text { No. of } \\
\text { persons }\end{array}$ & $\begin{array}{l}\% \text { Days } \\
\text { per } \\
\text { person }\end{array}$ & Index & $\begin{array}{l}\text { Spells } \\
\text { per } \\
\text { person }\end{array}$ & Index & $\begin{array}{l}\text { Days } \\
\text { per } \\
\text { spell }\end{array}$ & Index \\
\hline \multirow{3}{*}{ Male } & B & 1859 & 5.2 & 100 & 1.31 & 100 & 14.1 & 100 \\
\hline & G & 2762 & 7.9 & 152 & 1.77 & 135 & 15.8 & 112 \\
\hline & $\mathrm{N}$ & 3132 & 8.9 & 171 & 2.08 & 159 & 15.8 & 112 \\
\hline \multirow{3}{*}{ Female } & B & 386 & 8.6 & 100 & 1.77 & 100 & 16.7 & 100 \\
\hline & G & 969 & 10.6 & 123 & 2.27 & 128 & 16.7 & 100 \\
\hline & $\mathrm{N}$ & 346 & 9.6 & 112 & 2.70 & 153 & 13.0 & 78 \\
\hline \multirow{3}{*}{ Staff } & $\mathrm{B}$ & 611 & 3.2 & 100 & 1.01 & 100 & 10.9 & 100 \\
\hline & G & 941 & 5.2 & 163 & 1.59 & 157 & 11.6 & 106 \\
\hline & $\mathrm{N}$ & 1767 & 6.0 & 188 & 1.78 & 176 & 12.3 & 113 \\
\hline \multirow{3}{*}{ Manual } & $\mathrm{B}$ & 1634 & 6.7 & 100 & 1.55 & 100 & 15.5 & 100 \\
\hline & G & 2791 & 9.8 & 146 & 2.00 & 129 & 17.3 & 112 \\
\hline & $\mathrm{N}$ & 1711 & 12.1 & 181 & 2.52 & 163 & 17.7 & 114 \\
\hline
\end{tabular}

For female employees Belgian firms still show the lowest rates but the rank order in severity rates are not congruent with the one observed in the male sub-group. Furthermore, the range of differences is smaller if compared across female personnel. For both gender categories spell duration figures suggest minor international differences, which might be explained, however, to different age structures. Finally, these figures demonstrate the conclusions from our separate case studies, frequency and severity rates being substantially higher among female than male employees. In nearly all firms, and consequently in the national groups, virtually similar relations of sex with absence rates have been observed.

Table 6.4 additionally shows that the occupational status does not affect our findings fundamentally either. Four case studies consistently showed that the original rank order (B-G-N) is still maintained for each measure. Moreover, our figures indicate that in each firm manual workers demonstrate consistently higher absence rates than staff personnel. In seven (out of 11) firms rates for manual workers were about twice as high as for staff employees.

\subsubsection{Highest rates in Dutch firms}

So far the comparisons have been based on unstandardized data from four case studies and from pooled data. With a considerable degree of consistency they showed identical patterns of cross-national differences, and quite similar relations of absence rates with major population characteristics. As the distributions of these variables were not always identical (cf. Section 6.1.2) direct standardization has been applied to provide unbiased comparisons (cf. Table 6.5). 
Table 6.5 Overview of indices for severity and frequency rates in four case studies after direct standardization (1980 and 1981)

\begin{tabular}{|c|c|c|c|c|c|c|c|c|c|}
\hline & & \multicolumn{4}{|c|}{$\begin{array}{l}\text { Index } \\
\% \text { Days per person }\end{array}$} & \multicolumn{4}{|c|}{$\begin{array}{l}\text { Index } \\
\text { Spells per person }\end{array}$} \\
\hline & & \multicolumn{4}{|c|}{ Cluster } & \multicolumn{4}{|c|}{ Cluster } \\
\hline & & 1 & 2 & 3 & 4 & 1 & 2 & 3 & 4 \\
\hline \multirow[t]{3}{*}{ Unstandardized rates } & B & 100 & 100 & 100 & 100 & 100 & 100 & 100 & 100 \\
\hline & G & 133 & 185 & 136 & - & 133 & 146 & 160 & - \\
\hline & $\mathrm{N}$ & 113 & 158 & 161 & 205 & 144 & 158 & 173 & 155 \\
\hline \multirow[t]{3}{*}{ Standardized rates } & B & 100 & 100 & 100 & 100 & 100 & 100 & 100 & 100 \\
\hline & G & 125 & 192 & 112 & - & 149 & 161 & 166 & - \\
\hline & $\mathrm{N}$ & 157 & 167 & 172 & 246 & 195 & 160 & 198 & 175 \\
\hline
\end{tabular}

After this correction procedure our cross-national rank order has become more marked and consistent. Now just one cluster (nr.2) still demonstrates a deviant pattern; all other cases show the well-known rank order. Moreover, differences between the lowest (Belgian) group and highest group (Dutch) have been sharpened, as expected. It is suggested that sickness absence in German firms does not take a clear intermediate position as there is considerable variation to be noted in the position between both extremes.

Table 6.6 Average annual severity and frequency rates standardized for sex, age and occupational status in three national groups (1980 and 1981)

\begin{tabular}{|c|c|c|c|c|c|c|c|c|c|c|}
\hline \multirow[b]{2}{*}{$\begin{array}{l}\text { Mea- } \\
\text { sure }\end{array}$} & \multirow[b]{2}{*}{ Firm } & \multirow[b]{2}{*}{$\begin{array}{l}\text { No. of } \\
\text { persons }\end{array}$} & \multicolumn{8}{|c|}{ Spells lasting } \\
\hline & & & $\begin{array}{l}1-7 \\
\text { days }\end{array}$ & Index & $\begin{array}{l}8-42 \\
\text { days }\end{array}$ & Index & $\begin{array}{l}\text { 43-365 } \\
\text { days }\end{array}$ & Index & Total & Index \\
\hline$\%$ Days & B & 2244 & 1.1 & 100 & 2.0 & 100 & 2.5 & 100 & 5.6 & 100 \\
\hline & G & 3731 & 0.9 & 82 & 3.9 & 195 & 3.0 & 120 & 7.8 & 139 \\
\hline person & $\mathrm{N}$ & 3498 & 1.4 & 127 & 3.9 & 195 & 5.4 & 216 & 10.7 & 191 \\
\hline Spells & B & 2244 & 0.81 & 100 & 0.42 & 100 & 0.09 & 100 & 1.32 & 100 \\
\hline per & G & 3731 & 0.92 & 114 & 0.82 & 195 & 0.11 & 122 & 1.86 & 141 \\
\hline person & $\mathrm{N}$ & 3498 & 1.24 & 153 & 0.83 & 198 & 0.18 & 200 & 2.25 & 170 \\
\hline
\end{tabular}

The main results of our controlled comparisons have been presented in Table 6.6 , showing figures as if for our three populations not only type of products or organizational sizes were identical, but also age structure, sex ratio and proportion of staff and manual workers. In the light of the central problem stated we now already may answer three subquestions (cf. Section 4.2) regarding the magnitude, structure and consistency of cross-national differences. Among the Belgian group the lowest level of sickness absence is found, whereas comparable Dutch employees take $70 \%$ more spells a year and about $90 \%$ more calendar days are lost. German personnel now clearly take a middle rank of both absence measures. Short term sickness absence, lasting 1-7 days, has been taken $50 \%$ more in the Dutch group than in the Belgian group. The German and Belgian figures hardly differ: German employees show a higher incidence but this produces less days lost than in the Belgian group. For the medium term duration class (spells lasting 8-42 days) in part a 
different pattern has become apparent: Belgian firms still show the lowest frequency and severity rates but now both German and Dutch employees show nearly twice as many medium term spells per person as their Belgian counterpart. Severity rates differ in an identical way. Finally, the three groups show overwhelmingly divergent frequency and severity rates of long term sickness absence (43-365 days). The Dutch group has about 60-100\% more spells per person than the comparable German and Belgian group, creating $80-120 \%$ extra days lost in this category.

\subsection{A closer look at some cross-national differences}

A detailed analysis of differences in the structure of sickness absence may provide further insight and clues for the explanatory part of our study. In the light of the matching of firms and the high consistency of case study findings the further analysis in this section will be restricted to pooled data for each national group.

\subsubsection{Seasonal patterns}

Sickness absence rates fluctuate throughout the year, due to vacation periods and weather conditions. Low rates during summer are generally associated with a common vacation period for employees, whereas climatological effects are likely to account for high rates in winter and autumn (e.g. acute respiratory syndromes). Our selection of firms does not show serious deviations from the seasonal effects usually observed in investigations and statistics (Maib, 1981; Vrijhof \& Andriessen, 1986). Maximum rates are observed in February-March, lowest rates are found in July-August and a smaller peak occurs in OctoberNovember (cf. Figure 6.2).

Figure 6.2 Frequency rates by month for three national groups $(1980,1981)$

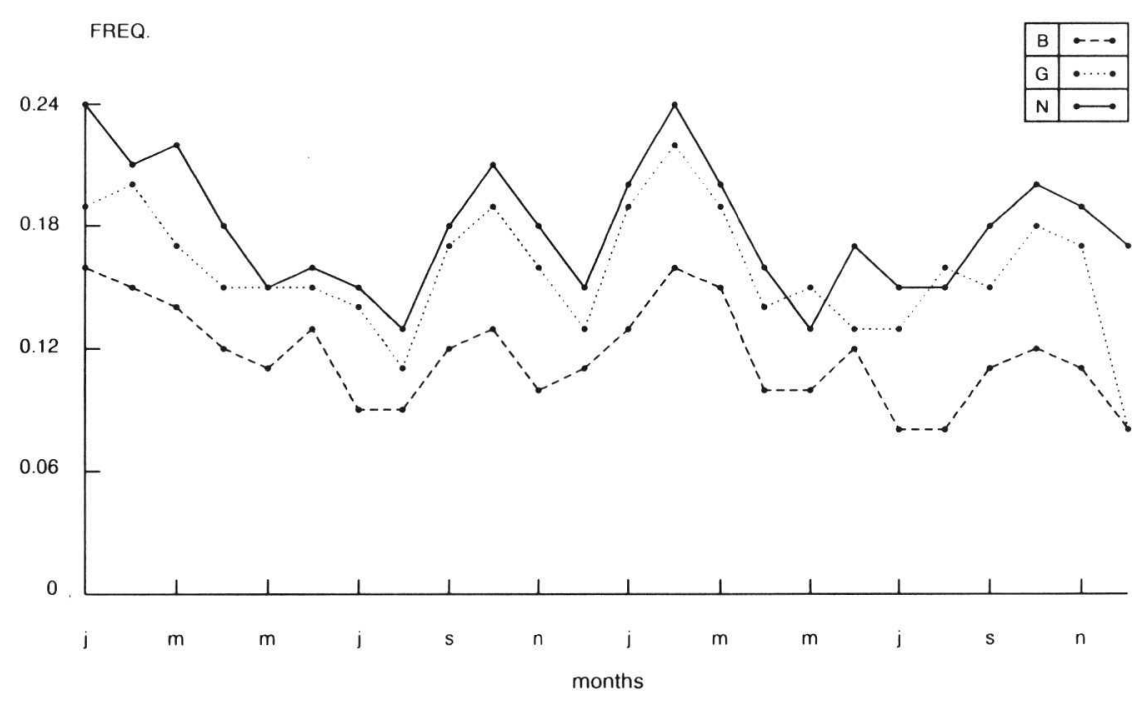


Compared to German and Dutch patterns Figure 6.2 may suggest sickness absence in the Belgian group being less affected by seasonal effects. The coefficient of variability $\mathrm{V}$, which more appropriately disregards measurement units (standard deviation divided by mean; Blalock, 1960), however, indicates smallest variations in Dutch rates $(\mathrm{V}=.170$, being .204 and .193 for Belgian and German employees respectively). Furthermore, in all populations the observation could be made, that the seasonal patterns is much more pronounced in sickness absence of manual workers than in staff absence rates.

\subsubsection{Absence frequency distributions}

In next two sections a closer examination will be made of spell frequency and duration in our groups. This examination may give an insight whether the high Dutch frequency rates are due to a larger proportion of persons taking an absence, or whether the members of this group are more frequently sick. Furthermore, some light may be shed on the distribution of spell lengths, which previously could only be studied in three broad duration classes.

Table 6.7 Frequency distribution of sickness absence in three national groups (average 1980 and 1981)

\begin{tabular}{lcccccc}
\hline $\begin{array}{l}\text { Number of } \\
\text { absences }\end{array}$ & Persons & $\%$ & Persons & $\%$ & Persons & $\%$ \\
\hline 0 & 698 & 33.8 & 797 & 23.0 & 784 & 24.2 \\
1 & 616 & 29.8 & 965 & 27.8 & 766 & 23.7 \\
2 & 384 & 18.6 & 750 & 21.6 & 598 & 18.5 \\
3 & 216 & 10.4 & 484 & 14.0 & 448 & 13.8 \\
$4+$ & 154 & 7.4 & 472 & 13.6 & 642 & 19.8 \\
\hline Total & 2068 & $(100 \%)$ & 3468 & $(100 \%)$ & 3238 & $(100 \%)$ \\
\hline
\end{tabular}

As the distribution of spell frequencies may be biased by high percentages of new employees or a high labour turnover, the comparison will be restricted to those persons employed an entire year. It becomes obvious, firstly, that about one-third of Belgian employees does not take any absence due to sickness during a year. The proportion of "never sick" is considerably smaller in both other groups (23-24\%). Secondly, the Dutch group shows the highest proportion of "frequently sick" : about $20 \%$ of employees reports over three times sick per year. For the German and Belgian group 13.6 and $7.5 \%$ respectively of persons fall into this category of "repeaters".

In general no or just one spell per year appears to be the rule in the Belgian population (Median-B: 1.0), whereas in both other groups higher spell frequencies seem to be typical (Median-G: 1.3; Median-N: 1.6). These differences in absence taking behavior are further illustrated by the maximum spell frequency noted within a year: for the Belgian and German groups the upper limit of the Range was 11 and 12 spells respectively, being 17 among Dutch employees. 
Figure 6.3 Relative distribution of absence frequencies over a two-year period in three national groups (1980 and 1981)

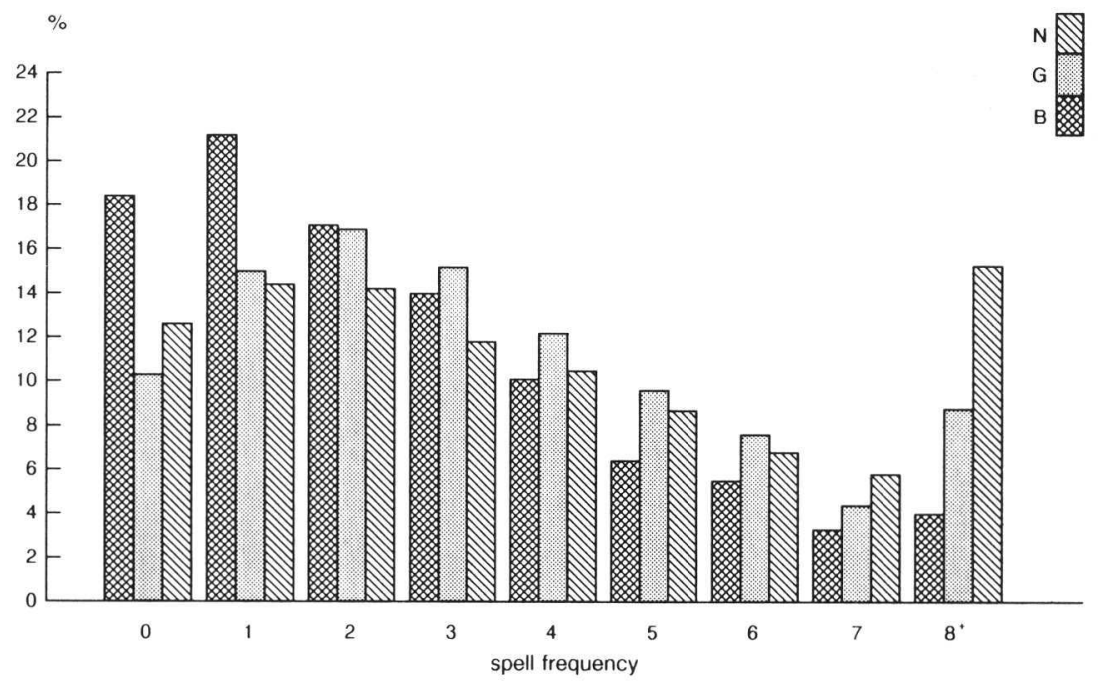

The stability of these patterns is further supported in two ways. On the one hand by comparing the frequency distribution for those persons employed over the entire two-year observation period (cf. Figure 6.3). In the Belgian group low spell frequencies are obviously prevalent (Median: 2.1, Range: 19), the German population takes an intermediate position (Median: 3.0, Range: 22 ), and the Dutch group is typified by comparatively high frequencies (Median: 3.3, Range: 31). On the other hand it can be shown that sex-specific and work-specific distributions do not essentially affect the differences observed between groups. Sex and occupational status show associations with spell frequency which are common for all groups. For instance, the percentage of "never sick" is highest in male or staff personnel, whereas the proportion of "frequently sick" generally is highest in female or manual workers.

\subsubsection{Spell lengths reconsidered}

The standardized data discussed in Section 6.1.3 (cf. Table 6.6) provided a relatively unbiased and first view on the length of spells in each group. Notwithstanding substantial cross-national differences in the volume of short, medium and long term sickness absences, the duration pattern within each group shows many similarities (cf. Table 6.8 ). Within each group the majority of spells (50-61\%) lasts up to one week, producing a minor part of days lost (12-20\%). On the contrary, the relatively small number of long lasting spells (less than 10\%) accounts for a large proportion of days lost (38-51\%). This relative distribution is well-known from studies andstatistics in most countries (e.g. Adriaenssens, 1985; Vrijhof \& Andriessen, 1986; Gut et al., 1983). 
Table $6.8 \quad$ Relative distribution of absence rates by duration class in three national groups (1980 and 1981)

\begin{tabular}{|c|c|c|c|c|c|c|}
\hline \multirow[b]{2}{*}{$\begin{array}{l}\text { Mea- } \\
\text { sure }\end{array}$} & \multirow[b]{2}{*}{ Group } & \multirow[b]{2}{*}{$\begin{array}{l}\text { No of } \\
\text { persons }\end{array}$} & \multicolumn{4}{|c|}{ Spells lasting } \\
\hline & & & $\begin{array}{l}1-7 \\
\text { days }\end{array}$ & $\begin{array}{l}8-42 \\
\text { days }\end{array}$ & $\begin{array}{l}43-365 \\
\text { days }\end{array}$ & Total \\
\hline$\%$ Days & B & 2244 & 20 & 36 & 44 & $100 \%$ \\
\hline per & G & 3731 & 12 & 50 & 38 & $100 \%$ \\
\hline person & $\mathrm{N}$ & 3498 & 13 & 36 & 51 & $100 \%$ \\
\hline Spells & B & 2244 & 61 & 32 & 7 & $100 \%$ \\
\hline per & G & 3731 & 50 & 44 & 6 & $100 \%$ \\
\hline person & $\mathrm{N}$ & 3498 & 55 & 37 & 8 & $100 \%$ \\
\hline
\end{tabular}

Notwithstanding, there are also some small variations, which may typify our groups. The Belgian group shows the highest proportion of short absences, whereas medium term spells prevail in German sickness absence (accounting for $50 \%$ of all days lost). Finally, the Dutch group may be characterized by its high proportion of long term spells, also contributing $50 \%$ of sickness absence days. These differences can be examined more systematically by using more detailed data on spell durations.

Figure 6.4 Annual mean frequency of spells by length (1-15 days) in three national groups (1980 and 1981)

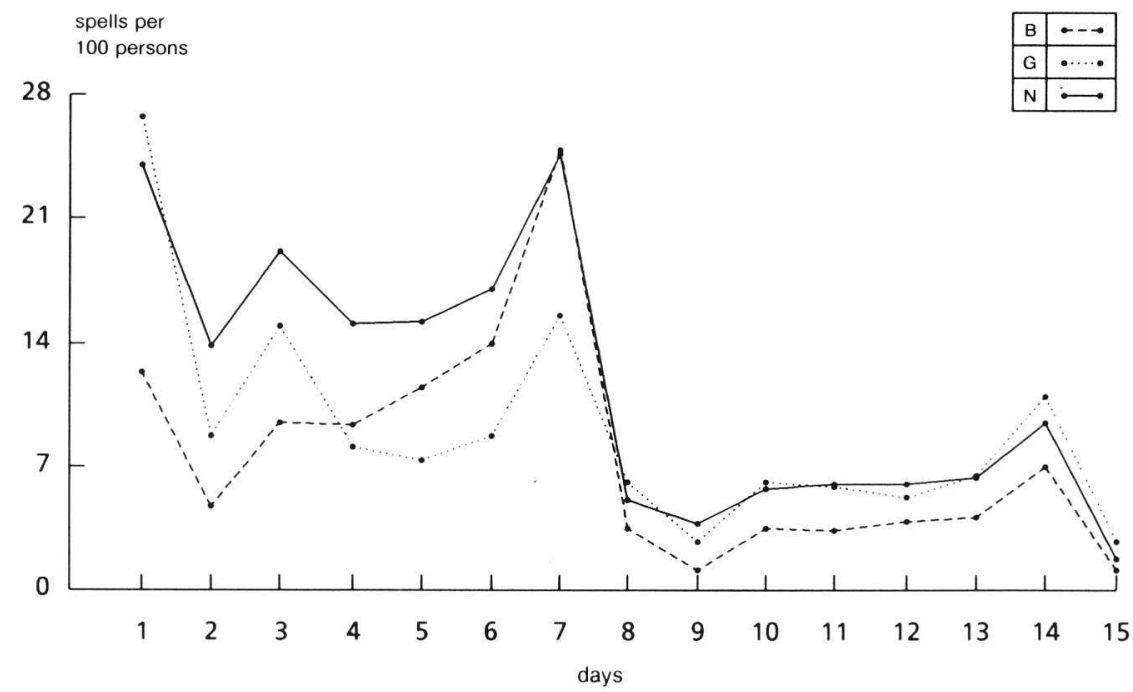

For short term absences, lasting up to seven days a $50 \%$ higher frequency rate has been found in the Dutch group. Figure 6.4, showing the frequency distributions of absences lasting up to 15 days, reveals some striking differences between the groups under study: 
1. The Belgian population shows the lowest frequency of one-day spells, but also the highest number of seven-day absences per person. In this group seven-day spells even show a 100\% higher frequency than one-day spells. These seven-day spells have an overriding influence on short term absence: they account for about $30 \%$ of all spells in this class. Furthermore, after this week a dramatic drop in spell frequency can be observed. The distribution indicates legitimating work incapacity for a one-week period is quite common among Belgian physicians.

2. In the German population a quite opposite pattern is obvious: one-day spells are most prevalent here, also contributing $30 \%$ of all spells in this class. In particular the frequency of absences lasting four to seven days is remarkably low which may suggest an effect of legitimation procedures, as for nonmanual employees (and in some firms for manual workers too) certification becomes obligatory from the fourth day of work incapacity;

3. Finally, these patterns of absences being typical for the German or Belgian group seem to be integrated in the Dutch distribution. Both one-day and seven-day spells take a dominant position in the Dutch short term absences. Moreover, for two- up to six-day spells the highest frequencies also have been found. For this group too a substantial fall in frequency rates after one week may be observed.

Figure 6.5 Mean annual number of spells per 1000 persons by length, 1-13 weeks, (1980 and 1981), logarithmic transformation

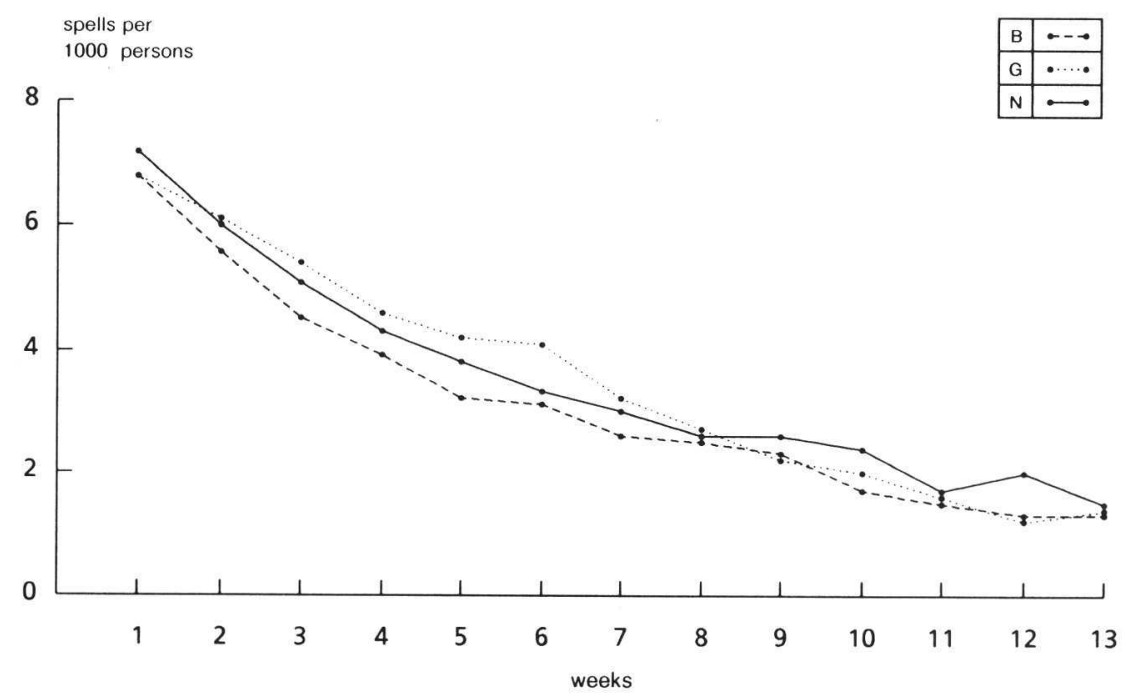

How far sickness benefits administration procedures, etc. may account for these problems will be examined in Chapter 10. Here it may be concluded, that the higher frequency for short term absences in the Dutch group is not concentrated in certain spell lengths. It is merely a general phenomenon, 
showing a higher frequency for (almost) all spell lengths. Compared to the lowest (Belgian) group Dutch employees take twice as many spells lasting one, two, or three days. Only the frequencies for six- and seven-day spells ressemble the Belgian levels. Furthermore, our data indicate spells lasting 8-15 days have a considerably lower frequency and show similar patterns. In each population the fourteen day-absences are at the top of the distribution, which, like the peak in 7-days spells, might suggest a general full-week favoured resumption of work.

Regarding medium term absences, lasting 1-6 weeks, Figure 6.5 specifies the high frequencies observed in German personnel.(1) It comes out that the German "top position" yields for the entire period. Compared to the Belgian group, differences steadily increase, showing their maximum in the 6th week. But rates for longer lasting absences are quite close to the Belgian level again.

We already know that in the Dutch population the frequency and severity of long term absences lasting 7-52 weeks is about twice as much as the Belgian rates (standardized). Figure 6.6 demonstrates that for virtually all spell lengths the frequencies (per 1000 persons) are the highest in the Dutch group. The German and Belgian group consistently take the middle and lowest position, respectively.

Figure 6.6 Average annual number of spells lasting over 13 weeks per 1000 persons by duration class in three national groups (1980 and 1981)

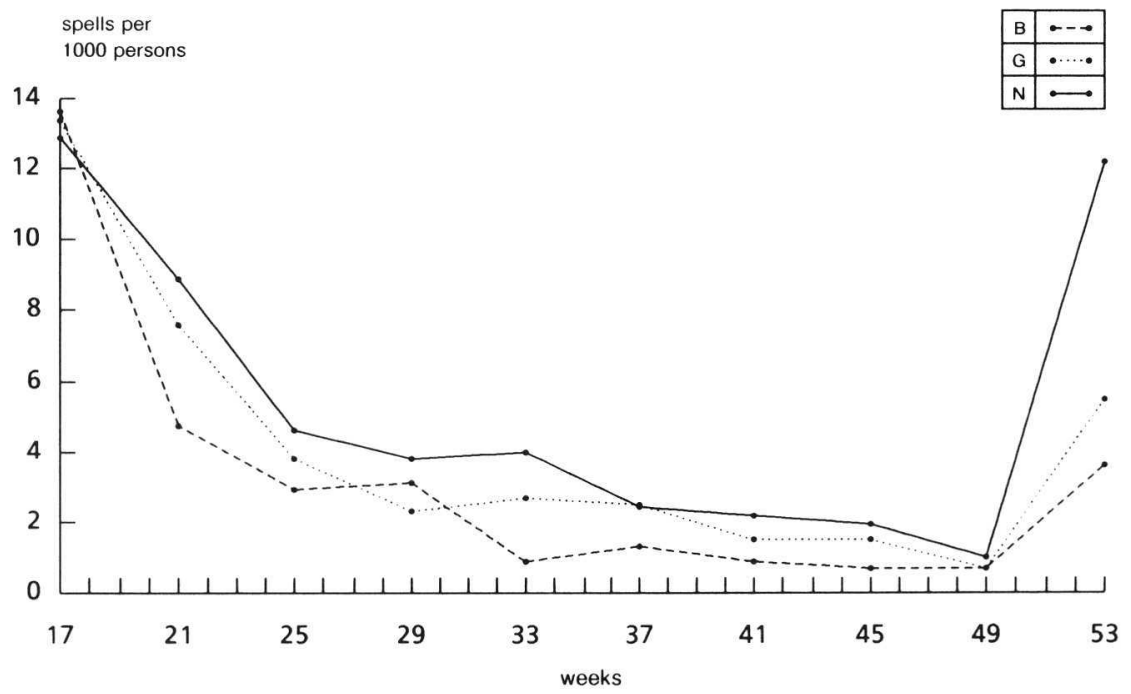

But most surprising is the overwhelming effect of spells lasting 49-52 weeks.(2) In all groups the final duration sub-class shows a remarkably high frequency rate, but the steepest rise has occurred in the Dutch group. Further detailed 
examination reveals a considerable difference in "maximum duration spells", lasting 52 weeks. Whereas in the Belgian and German group yearly just 3.1 and 5.2 of these spells per 1000 persons may be observed, respectively, in the Dutch population 11.9 absences can be noted annually. In their analysis of sick fund data Pfaff et al. (1986) noted larger differences: whereas in the German population $0.3 \%$ of spells lasted (over) one year, in the Dutch insured $1.5 \%$ of these spells were found.

Figure 6.7 Cumulative percentage of persons with an absence lasting 13-52+ weeks by week of termination in three national groups (1980 and 1981)

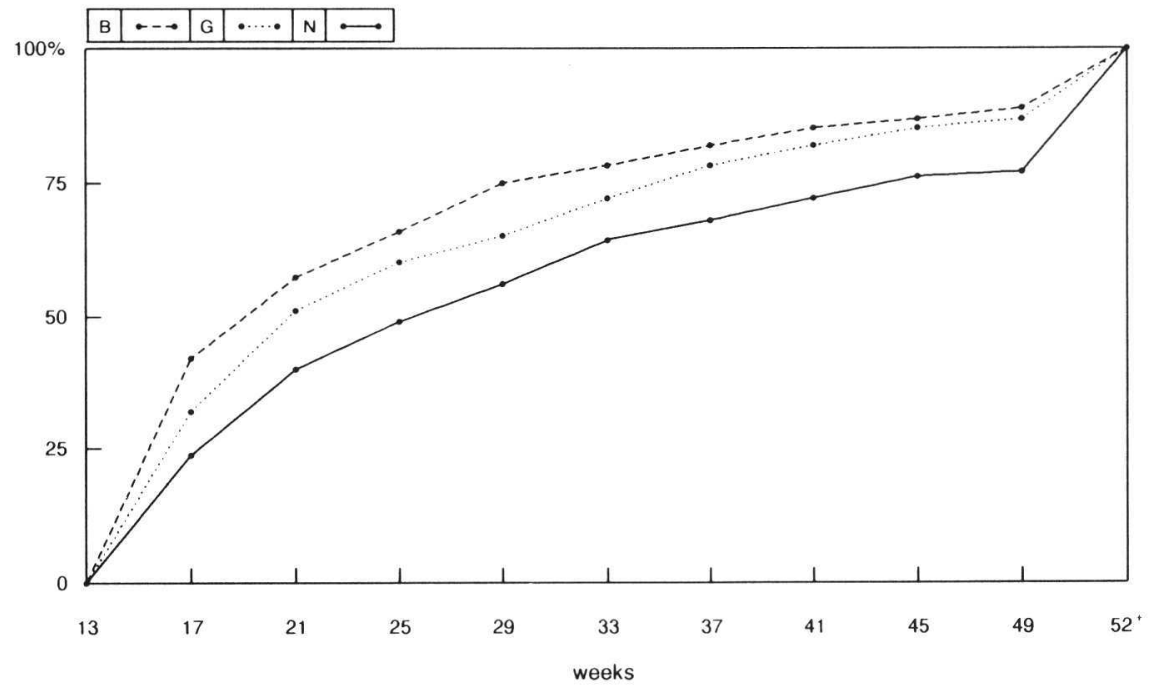

The overriding influence of spells with a maximum length on Dutch sickness absence is further illustrated by the pattern of termination and work resumption. Persons falling in the same category of serious sickness absence (operationally defined here as having an absence lasting over 13 weeks) return faster to work in the Belgian group than in the German and - in particular the Dutch group (cf. Figure 6.7). In the Belgian population already $42 \%$ of serious spells are concluded within four consecutive weeks, but in the Dutch group only $24 \%$ of spells are terminated. These differences are quite stable and have a maximum around the 29th week, that is to say spells lasting then about half a year. At that moment $75 \%$ of Belgian employees have resumed work, but in the Dutch population only $56 \%$ of spells have been concluded yet (German: $65 \%$ ). Moreover, in the Belgian group yearly about $11 \%$ of these serious spells enter into the 52 nd week of work incapacity, but for the Dutch group $23 \%$ are becoming a maximum spell (German: 13\%). It may be concluded that, in case of serious sickness absence, recovery and resumption of work take considerably longer in the Dutch group, and the probability of completing at a full year of work incapacity is much larger for Dutch personnel than for their foreign colleagues. 


\subsection{A comparison of trends and recent estimates}

Now the question may be stated whether our conclusions based on data from 1980 and 1981 still hold for more recent years. The answer will be sought by a comparison of trends in national sickness absence rates and the calculation of estimates.

Provided eligibility criteria and methods of measurement have not changed, social security data may fruitfully be used to compare time trends in sickness absence (cf. Taylor, 1969). For the German and Dutch population rates have been found, though not directly comparable, allowing insight in trends within each country, as they cover highly similar populations of insured. German sources are based on a monthly sample of insured reported sick (Lefelmann, 1984; Sozialstatistik 1987, 1988) whereas yearly overviews of the Social Security Council provided rates ("risk percentages") for Dutch insured (Vrijhof, 1986; Sociale Verzekeringsraad 1987, 1988). These severity rates have been related to a common point in time, namely the first year of observation (1970); they are presented as ratio's (annual rate divided by 1970-rate). For Belgian employees rates were calculated from overviews of number of days benefits were paid. So this measure only covers sickness absences lasting over one week (wage earners) or over four weeks (salaried employees).(3)

Figure 6.8 Sickness absence in Belgian, German and Dutch insured 1970-1987 (severity ratios: $1970=100$ )

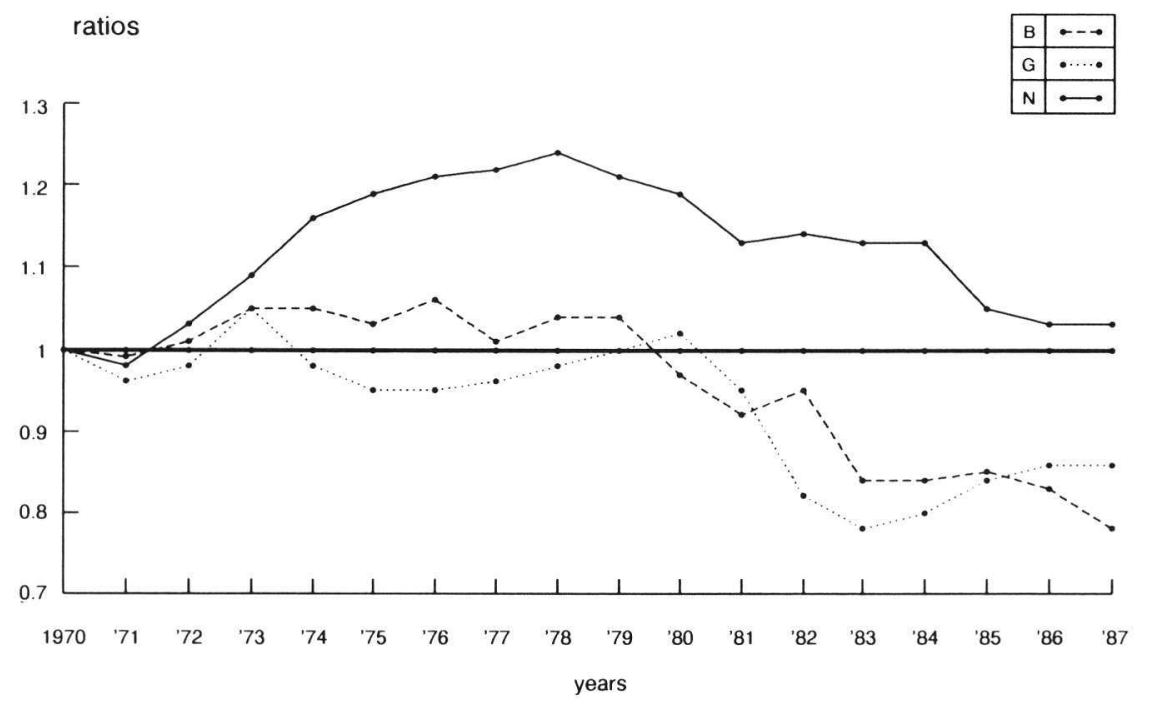

Figure 6.8 indicates some modest differences in time trends. Sickness absence in the Belgian and German populations was quite stable for a decade but considerably decreased after 1979,1980 . Dutch sickness absence was steadily growing until 1978 but the trend since has been consistently downwards. For the German insured sickness absence rates seem to rise again since 1983. It is 
still too early to say whether sickness absence levels already have stabilized in both other countries. We may conclude that after 1980 quite similar trends can be noted in our countries, which also will support the view that our conclusion on "the cross-national rank order" found sofar will still be valid.

A first attempt at making a recent direct comparison was made by Prins \& Peeters (1986). Belgian rates (adapted and derived from benefits statistics) and Dutch figures (based on NIPG-statistics) supported our earlier findings. On average in Belgian insured severity rates were $1 / 3$ (females) or $1 / 2$ (males) lower than in Dutch employees.

Our expectation is also supported by a comparison of recent sickness absence estimates from our three countries under study by combining Pfaff's approach with the use of weighting factors from our inquiry. As severity rates are less sensitive to the effects of underregistration of short term spells, only this measure has been estimated. In accordance with the method applied in this inquiry (Pfaff et al., 1986) absence percentages were calculated from sickness benefits data, which have been adjusted for serious biases. Belgian rates were calculated from benefits administration data, applying a weighting technique to include days due to spells lasting 1-7 days (wage-earners) or 1-28 days (salaried employees) paid by the employer.(4) German rates are based on statistics from Local Sick Funds, correcting for spells lasting over 52 weeks.(5) Finally, for the Netherlands statistics from industrial associations have been used as estimates. ${ }^{(6)}$ The outcomes of our measurements have again been standardized to age and sex, referring to the Dutch population in 1983, which allows a direct comparison and elimination of ageing effects.

Figure 6.9 Estimated sickness absence percentages in Belgian, German and Dutch insured, standardized to age and sex (1983-1987)

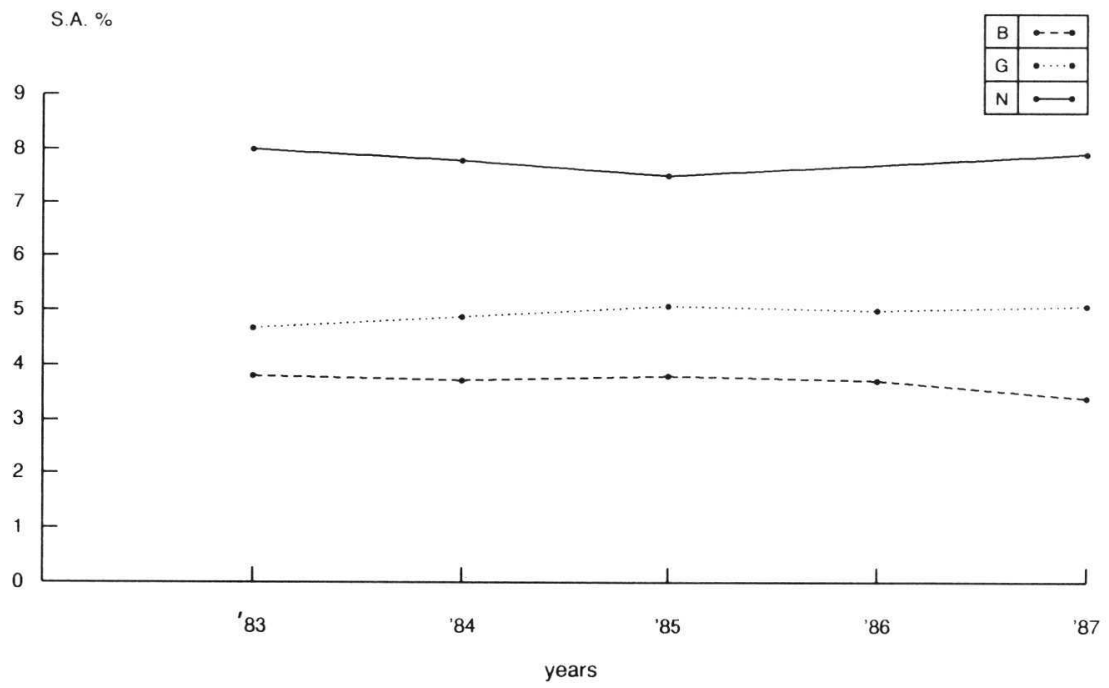


Notwithstanding the restrictions of our data it is obvious that sickness absence is still lying on a considerably higher level in the Netherlands, compared to both neighbouring countries (cf. Figure 6.9). The rank order observed in 19801981 in our clusters still holds, though differences between Belgian and German rates seem to be smaller. For 1987 estimated sickness absence percentages for Belgium, Germany and the Netherlands were 3.4, 5.1 and 7.9 respectively, showing a fairly identical range of differences as we observed in our firms in 1980-1981.

Figure 6.10 Number of spells lasting over six weeks per 1000 insured in Belgium, Germany and the Netherlands. (1983-1987)

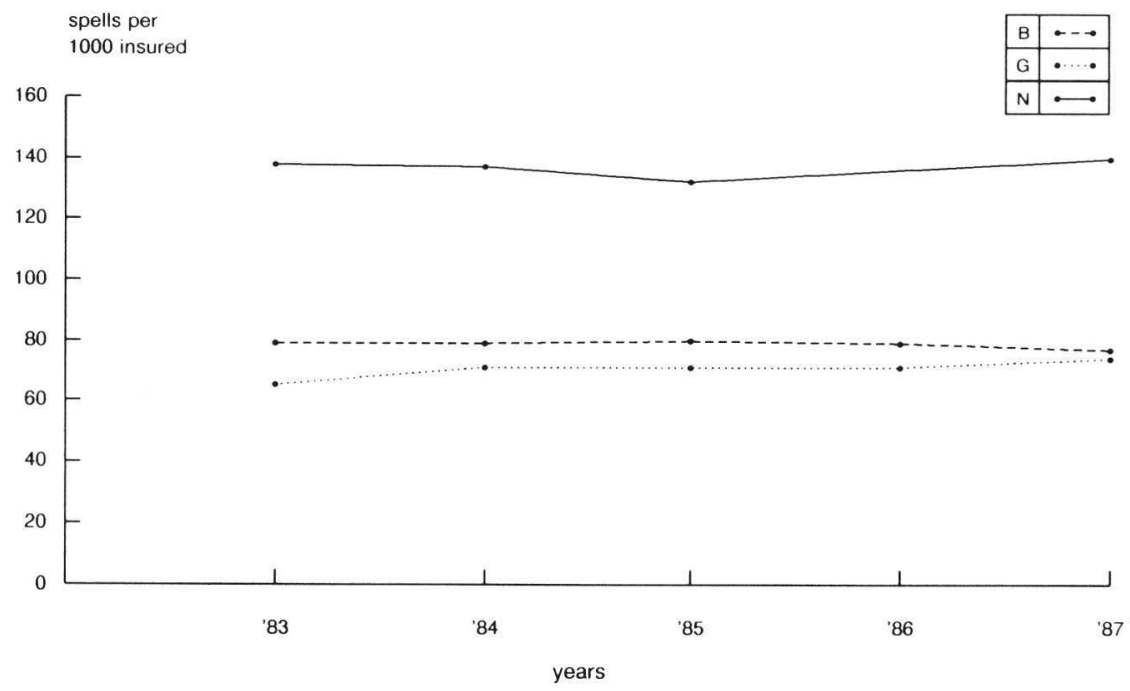

Finally Figure 6.10 indicates relatively high rates of long-term sickness absence still being a major characteristic of the Dutch population. Compared to the Belgian and German insured, consistently still about twice as many spells lasting over six weeks can be observed in the Dutch population (nonstandardized). In 1987 for the Dutch population still three times as many spells were reaching the 52nd week than in insured in neighbouring systems. The comparably high level of sickness absence, with a heavy weight of long term work incapacity, seems to be a quite stable characteristic of the Dutch population of (employed) insured.

These findings on recent cross-national differences support our earlier conclusions substantially. But in contrast to an explicite rank order, now figures suggest even a dichotomy, with Belgium and Germany on one end of the scale, and the Netherlands on the other. These findings further indicate that for the third part of our inquiry ("Interpretations") information from a longer and more recent period may be used. 


\subsection{Discussion}

The second part of our inquiry considered the first central question of our inquiry: the scale and nature of sickness absence in employees from Belgian, German and Dutch firms. The investigation focussed on the magnitude, type and consistency of cross-national differences as well as a comparison of trends. Our controlled comparison revealed, the magnitude and structure of sickness absence is consistently different between Belgian, German and Dutch employees (cf. Table 6.9).

Table 6.9 Summary of observed sickness absence differences

\begin{tabular}{lllll}
\hline & \multicolumn{4}{c}{ Sickness absence indicators } \\
\cline { 2 - 5 } Group & $\begin{array}{l}\text { Short } \\
(1-7)\end{array}$ & $\begin{array}{l}\text { Medium } \\
(8-42)\end{array}$ & $\begin{array}{l}\text { Long } \\
(43-365)\end{array}$ & Total \\
\hline Belgian & Low & Low & Low & Low \\
German & Low & High & Low & Middle \\
Dutch & High & High & High & High \\
\hline
\end{tabular}

Our first step in the comparative analysis supports the conclusions from less sophisticated studies examined in Chapter 2. Considerably higher sickness absence rates were found in Dutch employees which are mainly due to higher frequencies of medium and long term absences. But also short spells are taken more often in this group. These differences showed to be quite stable over time and were not substantially affected by population characteristics. On the contrary, a correction for dissimilar distributions in personnel variables (age, sex, occupational status) even enlarged initial differences. This finding matches conclusions in Pfaff's study considering a steep rise in Dutch severity rates after standardizing to age.

In more detail it was found that two elements may account for the highest frequency rates observed in Dutch firms. Absence from work due to sickness seems to be a widespread phenomenon in the Dutch population: comparatively more persons are absent from work than in the Belgian group and, besides, they report sick more often. In Belgian personnel the opposite pattern is obvious: a somewhat smaller proportion of employees report sick and, generally speaking, only once a year. This remarkable spell pattern was confirmed in Henderickx study: over a one-year period $36 \%$ of manual workers en $40 \%$ of staff did not report sick (Henderickx, 1985). Furthermore only about $30 \%$ of employees took more than one absence spell a year. The German pattern shows elements from both groups: sickness absence is associated with a relatively high proportion of employees, but their spell frequency is smaller than in the Dutch case.

Vis-à-vis the distribution of spell duration in Belgian and German employees an increased termination of sickness absence was observed on the days before procedures of benefits arrangement became active. German workers showed an increased frequency of spells lasting three days, whereas in Belgian employees remarkably lower incidences were observed after the day full wage 
payment terminates (for manual workers). An interpretation of these patterns in terms of employees absence behavior, medical certification habits (prescription of "fixed" periods of work incapacity) or recording procedures (spells reported on monday also cover absences starting on saturday or sunday) wil be subject of following chapters.

Also the socio-medical supervision of long-term sick, their (perceived) job security and, transfer to disablement programmes will need further attention. Differences regarding the "work resumption speed" as well as proportion of severe spells reaching (B, N), or passing $(G)$ the 52 weeks boundary suggest considerable cross-national differences on these aspects.

Finally, the validity of our findings as to region and period may evoke some questions. From the beginning it was clear that a small group of firms could not satisfactorily represent entire employed populations. However, the selection of firms (different sectors, various sickness absence levels) and the observed consistency in findings (after standardization; over years) considerably strengthen our conclusions, which are also supporting findings from local and less sophisticated cross-national investigations. Nevertheless, some reservations have to be taken into account. Firstly, the findings in Belgian firms should as such only be associated with the Flemish part of the country (cf. Section 4.7). Secondly, during interviews in our firms (Part III) it came out that our selection of Belgian firms, belonging to multinational enterprises, apply additional financial sickness arrangements; moreover they do not seem to practise rigid supervision of sick employees by private physicians. In these respects our Belgian sample does not resemble rank-and-file-firms, which even may be associated with relatively enlarged absence levels for this selection of firms. (7) Finally, in the Dutch group an opposite "bias" was noted: all firms showed to be self-administering their sickness benefits. Compared to being member of an industrial association this condition often indicates relatively lower absence levels (Nederlands Instituut voor Preventieve Gezondheidszorg, 1983). The balance of these potential sources of bias does not suggest, however, that our selection of firms is inappropriate in comparing cross-nationally. Furthermore, in each country national sickness absence levels dropped, but our estimates indicated that the rank order observed in the early 1980's still holds. The similarities between the Belgian and German rates suggest a' dichotomy with the Dutch rates being at the higher end of the sickness absence scale.

\subsection{Summary}

Our analysis of sickness absence rates in four clusters of comparable firms confirmed and notably enriched conclusions from methodologically weaker studies on the magnitude and structure of sickness absence differences. Compared with their Belgian colleagues, working in similar firms and with the same population structure (as to age, sex, occupational status) Dutch employees took $70 \%$ more spells of sickness absence a year and consequently about $90 \%$ more calendar days were lost $(1980,1981)$. German employees seem to take an intermediate position between both groups. Major differences were observed in medium (1-6 weeks) and long-term spells (7-52 weeks) with a nearly $100 \%$ surplus in both categories for the Dutch group. 
In Dutch firms absence taking behavior is characterized by the presence of many "repeaters", a small number of "never sick", and a relatively high frequency of (very) long lasting spells. On the contrary, among Belgian employees a relatively small proportion of persons reports sick and on average only once a year. These differences persist irrespective of spell length, with an exception for one day absences: for this category Belgian employees showed the highest frequency. Another major difference is the number of "maximum duration spells", i.e. absences, lasting up to 52 weeks. In the Dutch group the incidence of these absences is two or three times as high as in the German and Belgian group, respectively. This finding suggests the relevance of comparing the medical supervision procedures during work incapacity and the transfer to invalidity pension and alternative schemes.

Furthermore, the analysis of trends in social security data showed quite similar developments in German, Belgian and Dutch rates from 1980. In each country severity rates dropped, but stabilization cannot be confirmed yet. Finally an attempt was made to estimate more recent "national" sickness absence levels (by applying a weighting technique to benefits-related data). For a recent fiveyear observation period (1983-1987) our earlier conclusions were satisfactorily supported. On average Dutch insured still showed about 50\% more days lost than German insured (rates standardized for age and sex), whereas the surplus was over $100 \%$ compared to the Belgian population. Not surprisingly the incidence of absences lasting over six weeks in the Dutch population was still about $80 \%$ higher than in both other populations. It was concluded that the structure of differences observed in our case studies may still be highly valid, but Belgian and German levels seem to be converging. 


\section{NOTES}

(1) Frequency rates have been adapted in two ways to allow a fruitful representation. Firstly, by using as an indicator the number of spells per 1000 persons and secondly, by taking the natural logarithm of these frequencies.

(2) As the first observation year included 366 days the final class has been labelled $52+$.

(3) Calculated from: Rijksinstituut ..... (1988), Table 8, 23.

(4) From our own investigation a weighting factor has been calculated for each (of 20) combination(s) of age group, sex and occupational status. Subsequently accounting for this factor sickness absence days have been corrected to allow calculation of estimated severity rates (Rijksinstituut, 1983 ... 1987).

(5) This source, covering about $60 \%$ of obligatory insured German workers is partly lacking salaried employees and personnel employed in those large firms, which operate their own sick funds. Nevertheless, yearly statistics based on all sick funds indicate our source highly matches general severity rates. The underrepresentation of large firms makes it quite comparable to the statistics on the Dutch population. So German sickness absence rates were calculated from yearly "Krankheitsartenstatistik", published by the Bundesverband der Ortskrankenkassen (Bundesverband, 1983 ... 1987).

(6) Severity percentages have been calculated (for those years data were available) from "Diagnosestatistiek Bedrijfsverenigingen" (Centraal Bureau voor de Statistiek, 1982 . 1987). These data also cover work incapacity due to industrial accidents. Their bias is neglectable as these absence types only comprise about $2.5 \%$ of days lost (derived from Table 3.1 and 5.1, 1985).

(7) According to Smulders overview (1984a) the presence of more favourable financial consequences (high income replacement level) goes with more sickness absence spells and days lost. 
PART III

INTERPRETATIONS 



\section{THEORY AND METHODS}

\subsection{The purpose of Part III}

So far our analysis based on four case studies gave a detailed insight into some cross-national differences, which were shown to follow the trend of conclusions observed in studies with poorer data (cf. Chapter 2). Now the final part of our report will concentrate on the second problem of this investigation: "Which factors might account for these differences?"

To that end we will firstly examine major studies in each country and compare theoretical issues and empirical findings. The results of this step may be incorporated in an analytical model that attempts to guide our interpretion of findings in a comprehensive and systematic way. Therefore, the model will have to abstract from the Dutch case and try to throw light on those variables, relationships and underlying processes that may be applicable to each national situation. Subsequently, a selected range of factors or areas that may account for cross-national differences will be considered. The variatons in these areas should not be seen as isolated phenomena but within their socio-cultural context. Hence our findings will also be viewed in conjunction with some underlying cultural differences between Belgium, Germany and the Netherlands. Chapter 8 explores the association between population characteristics and cross-national absence differences. Subsequently Chapter 9 presents a cross-organizational comparison, concentrating on personnel management and sickness absence strategies in our cluster firms. In Chapter 10 our countries under study will be compared vis-à-vis social security programmes, general health status indicators and some socio-cultural aspects of work and health. Our results will be discussed in Chapter 11 which also will cast some light on latent or manifest consequences of comparatively high sickness absence levels.

\subsection{Major theoretical issues and research findings}

The countries under study differ considerably regarding the types and quantity of empirical studies carried out on sickness absence and its determinants. In reviewing most prominent investigations our interest will mainly be concentrated on theoretical premises, determinants investigated and research findings.

\subsubsection{Sickness absence in Belgium: a minor research issue}

Regarding the scarcity of statistics considered previously, it will not be very surprising to state that empirical studies on sickness absence also are quite rare in this country. In his overview of 318 studies on sickness absence Smulders (1984a) found just one Belgian investigation, dealing with sickness absence in migrant employees of an iron works. During our project we could find just a few more publications. 
The only available extensive survey on sickness absence in (Flemish) staff and manual employees was made by Henderickx (Henderickx, 1978, 1985). Integrating elements from decision theories (in particular Philipsen, 1969) and sociology of labour, sickness absence is mainly considered as a strategic action of employees towards unfavourable aspects at their employment situation (e.g. job content, working conditions, labour relationships). As only a small category of absences is attributable to objective diseases, it is stated, the majority of spells, being due to "subjective illnesses", may be fruitfully considered as a type of withdrawal, "a real alternative for turn-over, strikes, lateness". This first empirical investigation combines many of the hypotheses known from (international) literature on the subject. The mutual relationships of absence to individual characteristics (age, health condition, occupational status) have been confirmed. With a few exceptions, job-intrinsic variables also demonstrated expected associations.

Remaining investigations are generally descriptive, merely based on statistical data from several firms or just a single plant (Klaric, 1982; Peeters et al. 1985; Adriaenssens, 1985; Van Hall et al. 1986). In general many well-known associations of socio-demographic or company characteristics with sickness absence (frequency and severity) could be established. Also social security physician Depijperes (1985) findings on work incapacity due to sickness within 21.000 insured in the Brugge region generally supported conclusions from the literature.

\subsubsection{Sickness absence in Germany: a temporary topic}

Compared to the Belgian case in Germany much more public and investigative attention has been focussed on absenteeism ("Fehlzeiten"). Defined this way the phenomenon not only comprises work incapacity ("Arbeitsunfähigkeit") but also non-certified absences, sometimes labelled with pejorative connotations ("Krankfeiern"). The theorems and central questions of research seem to be considerably marked by socio-political debates and positions. Schneider \& Dennerlein (1985) indicated that interest in the subject predominantly emerged when sickness benefit regulations were (planned to be) changed, in periods of high absence rates, or after unexplained drastic falls. Generally speaking four approaches may be discerned, namely descriptive analysis, organizational psychology studies, work-stress-oriented investigations and a macro-economic approach.

Descriptive company-based studies are quite rare. One of the earliest studies of a representative sample of firms focussed on sickness absence, including illness and occupational accidents (Spiegelhalter \& Schnabel, 1962). Twenty years later Salowsky (1980) analysed severity rates of absenteeism (including sickness accidents, "Kur", uncertified absences). But also more elaborate studies based on (very) small samples of firms have been made (e.g. Maib, 1981; Hinze, 1982), whereas numerous "case studies" have been reported in personnel management journals. Work force characteristics generally showed assocations with absence measures similar to those usually mentioned in sickness absence literature. 
Organizational psychology studies usually move beyond the descriptive phase. The underlying theoretical models attempt to explain absenteeism in terms of employee reactions towards conflicts about working conditions or organizational norms. Zimmerman $(1969,1970)$ is one of the first authors who tries to apply sociological insights in explaining "industrial absenteeism". Firstly, it is stated the definition of health is not exclusively determined by traditional medicine, but it is also affected by individual decisions, administrative regulations and societal norms. Furthermore, in performing their jobs employees are confronted with organizational norms (imposed by technology, wage system, etc.) but they have only a limited range of coping strategies. So these absence types are considered as being interdependent and therefore should be interpreted as alternative ways to react to industrial conflicts.

This theoretical outlook on absenteeism could only partly be confirmed with empirical evidence from male employees from an iron mill. In general absence rates showed the well-known relationships with employee and job characteristics. Also the interrelations of absence types were found. Furthermore, factories showed striking differences in absenteeism which could not be solely explained by epidemiological conditions (physical work conditions, age structure of employees). So social factors (reactions towards tensions and conflicts in work life) which could not be investigated however, were considered to affect these differences.

About ten years later attention is again focussed on organizational and motivational factors in the first German reader on the subject of absenteeism (Nieder, 1979). Absenteeism ("Fehlzeiten") is primarily considered as an expression of poor motivation and job satisfaction. In investigations attempts are made to isolate the attitudinal or motivational segment of entire absence. This part is considered as avoidable and potentially to be influenced by improving the quality of working life (improvement of labor relations and leadership style, job enrichment, mechanization of monotonous work). Also Hinze (1982) reports about this type of "employee oriented action research". In calculating "absence proneness rates" it was assumed that as spells grow longer the probability of being a spell of attitudinal absence will decrease. Compared to "low proned group" and "never sick" the "high proned group" showed a significant correlation to negative experiences towards their work places (e.g. air quality, noise, etc.), work conditions (e.g. perceived safety and health risks) and job quality (e.g. autonomy, management style). Furthermore, demographic characteristics showed associations with absence proneness similar to those usually observed in general absence studies.

Work stress-oriented investigations, mainly based on work incapacity data from sick funds, seem to be a comparatively unique approach in studying sickness absence. They do not primarily aim at the search for motivational or other causes of high sickness absence. Attention is merely focussed on (certified) work incapacity as an indicator of work-induced sickness, which should be analysed for prevention purposes. Categories of employees with relatively high work incapacity rates on certain diagnoses are considered to be more exposed to occupational risks (accidents, stress) than low rating groups. Complementary surveys (on work stress and strains) in the work force could be used incidentally to give this approach a more stable empirical foundation. 
Both the studies of Georg et al. (1982), Halusa et al. (1982) and Gut et al. (1983) give insight into high risk groups and sectors by analysing the interrelationships of individual characteristics (e.g. profession, age, sex), economic sector and reported work incapacity (diagnosis, frequency and length of spells). Findings mostly confirm conclusions from earlier studies, but give a more detailed picture of professions and branches with remarkable diagnosisspecific work incapacity rates.

As Von Ferber showed also on company scale a micro-epidemiological version may be applied to detect groups of employees with work related "chronic-degenerative diseases" (Von Ferber, 1983).

An extensive theoretical frame of reference on backgrounds and trends in West German sickness absence has been provided by Dennerlein \& Schneider, (1985). Their macro-economic model of the work incapacity process in this country is not restricted to health status or work stress related factors. It also comprises aspects of the decision proces to report sick (e.g. job uncertainty or income reduction in case of sickness) and societal conditions. Temporal variations in sickness absence rates are related to changes in natural morbidity, health care provisions, working conditions, economic structure and employment, job security, transfer to disability pensions, etc. For indicators of these determinants ("latent variables") validity was sometimes unsatisfactory, and assumptions (as to linearity) were not always met. Taking these restrictions into account it could be concluded, sickness absence rates rose as job security increased, but this factor mainly affected spells up to six weeks. Furthermore, improvement of working conditions considerably decreased absence rates, in particular long term spells. Variations in medical provisions did not show significant effects on absence rates; moreover the introduction of compulsory continuation of full wage payment (1970) did not consistently account for rising absence rates either.

\subsubsection{Sickness absence: a continuous concern in the Netherlands}

In contrast to its neighbouring countries in the Netherlands sickness absence, and disablement, seem to be a regular topic in social policy and research. Four mainstreams may be discerned regarding the theoretical issues and empirical themes in Dutch research, namely descriptive quantitative inquiries, organizational sociology investigations, approaches focussing on individual health conditions and work stress, and studies dealing with institutional aspects (e.g. operation of benefit programmes).

One of the earliest descriptive studies examined time series of absence data from 40 enterprises and showed sickness absence to be a semi-constant characteristic for each firm (Ekkers, 1966). This firm-specific character of sickness absence was more obvious in diagnostic groups for minor ailments than in categories with serious diseases. After 1979 time series analysis became popular again as severity rates unpredictedly started to decline in this country. Some inquiries in a relatively short period showed that on a macroscopic level sickness absence rates are negatively associated with unemployment rates. Furthermore, it was evident that changes in the composition of the employed 
population played a larger role in the decline of absence than changes in individual absence behaviour. The common sense assumption "fear for dismissal reduces sickness absence" seems to lack a sound empirical confirmation for the Dutch situation. The falls in total absence were mainly associated with a reduction in the number of 'leavers' (with traditionally high absence rates) and their partial or total replacement by "entrants", usually showing lower absence rates (Kruidenier, 1984; Veerman, 1985; Vrijhof, 1986). Most quantitative studies just have descriptive purposes to detect high risk groups or to analyse associations of sickness absence measures to work force or company characteristics. Generally speaking most such associations known from foreign research also hold for Dutch employees.

The rise of absence frequency in a period of improved medical service and living conditions made it clear that not only health conditions could account for this phenomenon. Gadourek (1965) tried to shed more light on "non-somatic factors in absence-conduct", investigating individual absence from work as one indicator of lack of well-being in the work group (others being: low satisfaction, unfavourable subjective health conditions, complaints, etc.). Most attitudinal aspects of work did not show any significant relationship to absence behaviour, whereas many basic variables followed the pattern of relationships expected on theoretical grounds. It was concluded that the nature of the work process and organizational structure might be more relevant for the well-being of employees than attitudinal characteristics and working group factors.

A few years later Philipsen (1969) study provided further empirical support for this conclusion, by investigating causes of differences in absence rates from 83 industrial firms. The theoretical model underlying this study integrates factors and processes on individual, organizational but also on societal level, which may make it fruitful for our cross-national inquiry. On the individual level sickness absence behavior has been examined in terms of health related decision making. The experience of symptoms, medical care contacts, reception of treatment, and recovery or rehabilitation require individual decision making. The perceived dispensability at work as well as the attachment of the employee to his firm or work may operate as intermediate factors in the decision process. The content and degree of this relationship may affect the employee in deciding whether to report sick, prolong work incapacity or attend work.

In this investigation company data and interviews with personnel managers indicated that 19 plant characteristics showed significant associations with frequency and duration rates. Among factors noted to affect spell frequency were: stable and predictable working relations, opportunities for self-realisation, the operation of waiting days, and work inconveniences. A modern style of personnel management, and social monitoring of sick employees instead of rigid control practices were related to a relatively short duration of absences.

Though the decision making model has not been tested on an individual level (e.g by interviewing employees) it provided a fruitful interpretation scheme indicating that a considerable part of the absence rates are "company-made" and may be reduced by adequate firm policies towards working conditions, social relations and absent employees. Fifteen years later a replication of this study carried out by Smulders (1984b) showed considerably similar findings. 
From an occupational health point of view Vroege $(1982,1983)$ interpretes high sickness absence rates as a lack of equilibrium in the relationship of work load and work capacity. In the stress-orientated model presented an unbalanced relationship may be counteracted by three feedback mechanisms: time off ("recovery time"), loss of productivity and increasing sickness absence. It is supposed in particular the binomium "working time- time off" to be essential for a correct balance of the individuals workload and work capacity. For an empirical support of the model some macroscopic sickness absence rates have been examined. Differences in sickness absence (severity rates), working time, number of days off and productivity rates were compared for Germany, France, Great Britain and the Netherlands. Productivity figures for Germany, France and the Netherlands were quite similar but sickness absence and number of days off (due to annual leave, etc.) differed considerably and according to the pattern expected. Merely due to its socio-political suggestions this inquiry became quite controversial, and its methodological limitations indeed are not to be ignored (cf. Chapter 2). Despite its weak empirical basis, however, Vroeges study stimulated attention to be paid to the role of work load in the etiology of work incapacity. Some popularized interpretations of decision theories could easily be neglecting the health aspects of high sickness absence rates.

Among those variables found to account for differences in sickness absence between firms some aspects of the operation of benefits arrangements were shown to be of considerable importance. Philipsens investigation already showed that company membership of an industrial association (performing benefits programme administration, medical supervision of claimants, etc.) is strongly associated with higher absence levels. In his complementary study Smulders (1984b) observed the number of contacts between management, the personnel department and the insurance doctor also attributed to sickness absence differences between firms. These two observations illustrate a new complex of sickness absence factors, namely determinants in the province of health care facilities and benefits administration, which received growing attention (Buijs, 1985; Aarts et al., 1987).

Two studies investigated the structure and functioning of the health care system in so far they induced "iatrogenic" sickness absence (Tordoir et al., 1978; Soeters, 1984). This concept covers prolonged work incapacity and transfer to disability pension as a consequence of unnecessary, faulty or delayed medical intervention (Soeters \& Prins, 1985). By analysing diaries of employees with at least six weeks of work incapacity, "patient careers" within the work incapacity programmes and health care system could be identified. Considerable "waiting periods" were observed (periods in which no progress in treatment was made) which postponed recovery and resumption of work. About $20 \%$ of all work incapacity days were lost due to waiting periods, which were attributed to periods of referrals, waiting periods between reporting sick and consultation of the family doctor, or before hospital admission. Finally, both studies also identified "steerless periods" in which no attendant physician gave directions for (further) treatment (e.g. when therapy had been terminated without declaring the patient recovered or without referral to another specialist). This remarkable magnitude of iatrogenic work incapacity in the Netherlands may 
not only be due to the unevenly developed and distributed supply of health services but also to the lack of communication and coordination between various medical professions involved (occupational physician, general practitioner, insurance doctor). Regarding the latter aspect the Dutch situation seems to be quite unique (Andriessen et al. 1983). Communication and consultation between providers of care, occupational health departments and the social security sector seem to be less problematic in other countries. The authors indicated this was due to the lower levels of sickness absence, the structure of health risk insurances (e.g. separate accident insurance), accepted procedures and an cooperative attitude on information supply by general physicians and specialists.

\subsection{Cross-national similarities and particularities}

Regarding our inventory of Belgian inquiries it became clear that very limited extensive research has been carried out on sickness absence. With an exception of Klarics study, all investigations studied employees in a small number of firms in the Flemish part of Belgium which, due to economic and labor market structure, may generally have lower rates than the Wallon area (cf. Section 4.7). Most investigations demonstrated that many elementary findings from abroad, i.e. relationship to sickness absence, high risk groups, may credibly be applied to Flemish employees, too. Only Henderickx's investigation attempted to discuss prevailing theories and integrated labor participation processes. This inquiry should make us aware of the role played by factors such as (internal) labor market stability, experienced job security and labour attitudes as well as accompanying management strategies.

Our German sources indicated that sickness absence research is confronted with several restrictions, namely a lack of fruitful conceptualization, no regular representative studies or statistics nor any systematic explanatory research (Maib, 1981). This state of affairs facilitates or may be conditioned by the controversial character of the subject in this country. This is not only culturally expressed by the use of several synonyms with a pejorative flavour ("Blaumachen", "Krankfeiern", "Bummelanten") or reluctance of firms to permit an investigation to avoid "social unrest" in the work force (Dennerlein \& Schneider, 1985). Also tendencies to discern motivational absenteeism from "medical absence" or attempts to ascribe high absence rates mainly to work induced diseases indicate current state of sickness absence research.

Descriptive studies, mainly based on case-studies or sick funds statistics generally showed well known associations of sociodemographic variables to absence rates. Furthermore, some studies indicated that conflicts, complaints and perception of unfavourable working conditions accounted for low satisfaction and motivation which increased individual absence rates. However, job content and work stress also may directly affect health conditions and work incapacity, as some analysis of sick fund data indicated. Finally, certain investigations explicitly took elements of the social security context into account. Particularly Dennerlein \& Schneider (1985) integrated aspects from various fields into their model, which not only considered variables on health status and working conditions, but also socioeconomic factors (e.g. transfer to invalidity pensions or unemployment) and 
health care facilities. It may be concluded, that both on theoretical and empirical level more insights and information is available on determinants of sickness absence compared to the Belgian situation.

The relatively high level of sickness absence in the Netherlands as well as relatively favourable research conditions may account for the fact that our subject has been examined quite intensively and from various viewpoints in this country. Generally speaking sickness absence has predominantly been approached from a labour organizational angle, though the role of health conditions or the operation of health care facilities and work incapacity programmes attract more and more attention. Descriptive studies mostly confirmed the associations found in other countries. The impression is evoked Dutch research tradition probably incorporates the widest range of factors known to affect sickness absence.

The variety of factors and conditions investigated regarding their relationships to sickness absence may be summarized into four categories:

a. socio-demographic variables, affecting the composition of the working or insured populations: e.g. regarding age structure, sex, nationality;

b. work- and firm-related factors, referring to employment policies and working conditions;

c. benefits arrangements and their operation: eligibility criteria, medical supervision, transfer to invalidity programme, etc.;

d. socio-cultural aspects: views and attitudes regarding work and health.

Table 7.1 summarizes the conclusions found within each country.

Table 7.1 Major categories of sickness absence factors investigated in Belgium, Germany and the Netherlands

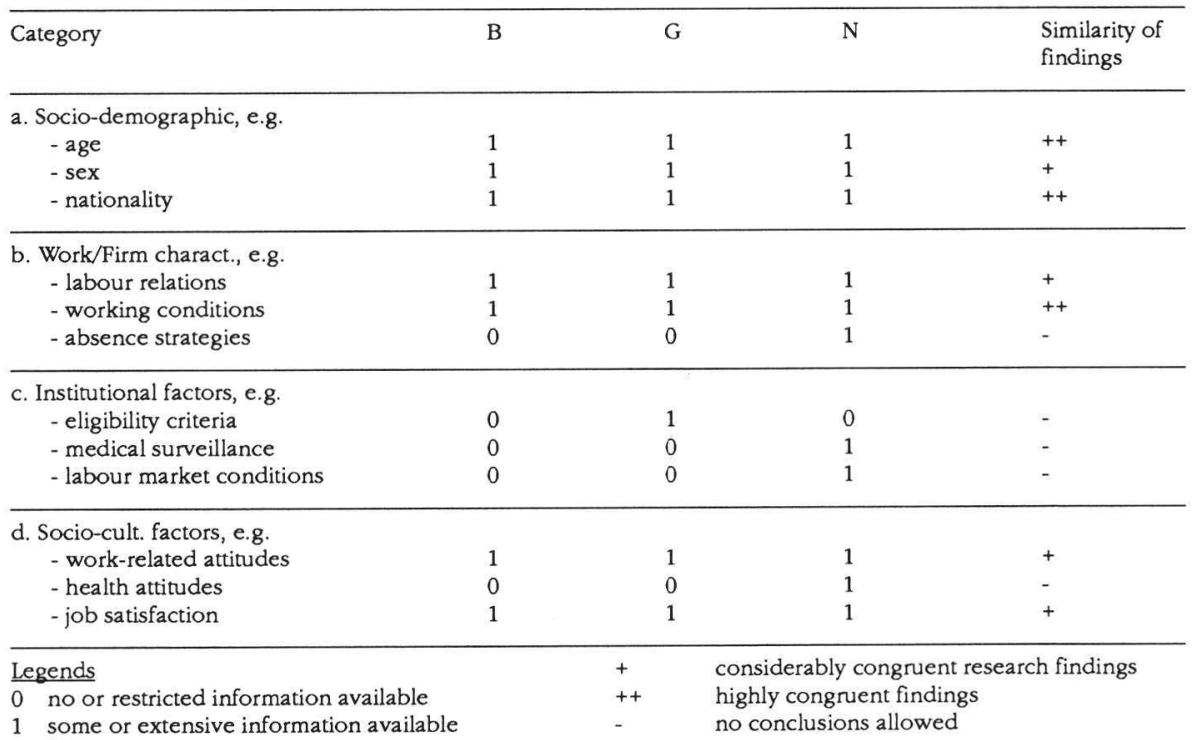


Our overview suggests many similarities between countries regarding the factors associated with sickness absence. Little attention has been paid to societal conditions, whereas epidemiological aspects (health status) also do not seem to be investigated extensively vis-à-vis sickness absence. To throw more light on some of these factors and their relevance in cross-national comparisons a theoretical framework will be developped that allows a more structured point of view on sickness absence differences.

\subsection{Towards an analytical model of sickness absence}

\subsubsection{Our dependent variable}

So far the Dutch version of the sickness absence concept could be fruitfully used throughout this inquiry. It covered absence from work due to sickness, irrespective of its causes (illness or disease, injury, and also including maternity leave) and neglected administrative differences between certified and non certified spells. In our search for explanations we will further approach sickness absence as a neutral concept and not as something negative, e.g. from the point of view of the company. Our dependent variable will primarily be regarded as a health-related phenomenon, covering a variety of elements ranging from psychological discomforts and minor ailments to medically observed diseases or injuries (Sturmans et al., 1982). The concept is not restricted to the classical notion of a clinically evaluated health condition. Due to societal health beliefs and attitudes ("tolerance thresholds") it may also incorporate complaints related to medicalised social and personal problems.

The inclusion of psychological conditions into this broad health-oriented definition may trigger attempts to discern "motivational" vs. "medical" reasons for absence from work. Our review of literature indicated that such an effort, usually based on the calaculation of individuals frequency of short absence periods, is not very fruitful. Further, short periods of absence may have a "regenerating" function for employees performing monotonous or arduous work. Bunnage (1981) suggested frequent absences may signalize growing work incapacity. Taking short spells may avoid longer absences and more prolonged degenerating effects of unfavorable working conditions.

However, from a different point of view, differences in length of absence periods need a prominent position in any further research. In due course "contextual factors" (operating in the province of benefits programmes or health care services) may affect a prolongation of sickness absence spells and the mode of their termination, e.g. by resumption of work, transfer to the disablement pension scheme (Dennerlein \& Schneider, 1985; Henderickx, 1985). Given our findings on medium- and long-term sickness absence a close examination of eventual specific "duration-determinants" will be necessary. Instead of considering the magnitude (volume) as the only dependent variable, here all its comprising elements will need further attention: the incidence, the duration and the completion of absence periods. 


\subsubsection{Individual sickness absence behaviour}

As the model guiding our further investigations should be applicable to sickness absence in different societal contexts, it should not only focus on relationships and variables on micro (individual) or meso-sociological level (work, place, company). In particular contextual factors on a macroscopic or societal level should be covered (e.g. sickness benefits arrangements or labor market conditions) which are known to differ between countries. To that end Philipsens decision-theoretical approach will be taken as a starting point, as it already integrates variables on micro- (individual) and meso- (firm) level. Several Belgian and German authors applied comparable decision-theoretical viewpoints (e.g. Henderickx, 1985; Zimmerman, 1970). To increase the suitability of this model a twofold extension will be necessary. Firstly, the striking differences in the way or rapidity of termination of long term absences were a major conclusion from our statistical analysis. So the decision making process regarding the employees status after long term sickness absence will need further concern. Secondly, as in most investigations and prevailing theoretical viewpoints, social security aspects played a moderate role in Philipsen's model, not surprisingly, as it originally aimed at explaining sickness absence differences between firms within a uniform social security context. Given the considerable differences demonstrated (Chapter 3) benefits regulations and procedures as well as macro-economic employment conditions will have a more prominent position in our model.

Figure 7.1 A micro-model of sickness absence bebaviour

(5)

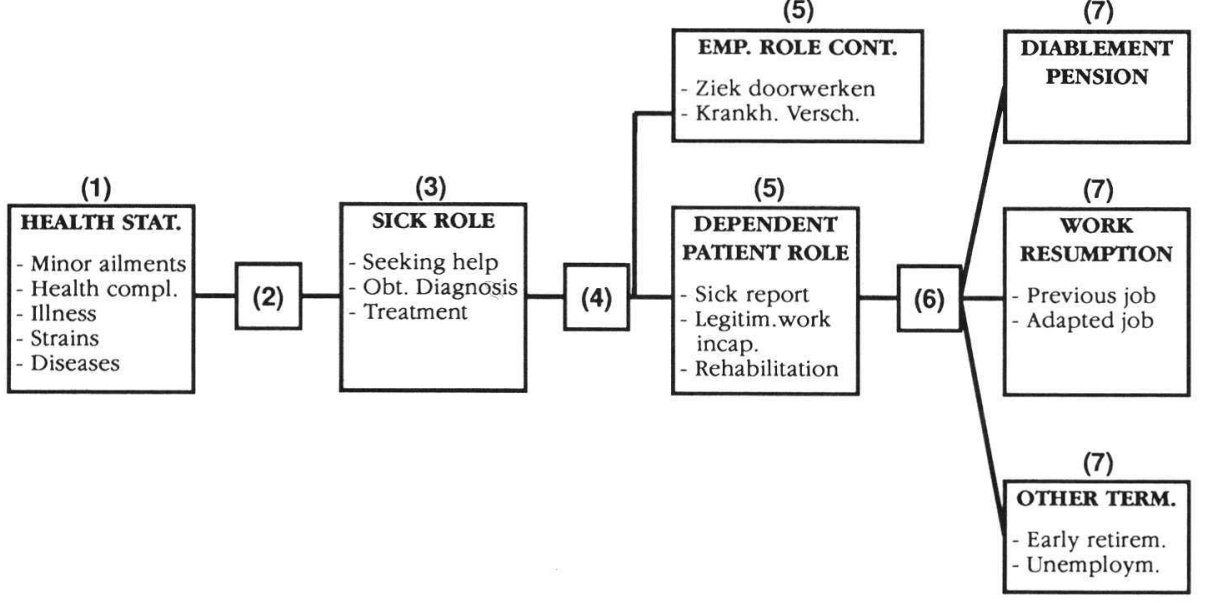

The core of the model lies in individual health and sickness behaviour (Philipsen, 1969; Netherlands Scientific Council for Government Policy, 1978; Becker \& Maiman, 1983). In case of minor or serious health complaints an individual is confronted with a sequence of events and health- or work related decisions he - or some medical authority - is to make (cf. Figure 7.1): 
1. the bealth status. The individual's constitution and the "supply" of health problems, ranging from minor ailments to serious disease, may be seen as the major determinant of an individuals general state of health;

2. the sickness tolerance threshold. This standard defines whether and when the experience of symptoms makes the individual decide to assume the sick role with its role expectations (e.g. attempts to obtain diagnosis, treatment, and restoration of health);

3. adoption of the sick role and its role expectations. The individual seeks and receives treatment to restore health or to stop the progression of disease;

4. the absence tolerance threshold. This standard on the scale ranging from slightly to seriously ill indicates when the individual (or his environment) considers himself released from the duty to attend work;

5. the dependent patient role. This status starts with reporting sick and is in some countries formalized by certification of the work incapacity through medical evaluation. In case of a high absence tolerance threshold the individual may however decide to continue to attend work;

6. the work resumption tbreshold. This standard, comparable with absence tolerance threshold, indicates the conditions likely to terminate the dependent patient role and allow resumption of work. Alternatively the employee role is terminated and an other branch of social security may be entered;

7. most spells of sickness absence are completed by resumption of the employe $e$ role. A very small minority of frequently or long term sick may (be forced to) substitute the dependent-patient role for a status as a disabled, unemployed or retired person.

This sequence of events contains three moments of decision making ("thresholds") which may function as "filters" before the state of work incapacity is being entered or terminated. The sickness tolerance threshold (2) considers health and illness behaviour in general, whereas the absence tolerance threshold (4) will only affect decisions of those who are employed.

The latter criterion has to be considered vis-à-vis cross-national spell frequency differences.

The work resumption threshold (6) is very relevant in the light of the remarkably higher long-term sickness absence levels found in Dutch employees.

The underlying process of being and staying work incapacitated has been schematically described by Hoogerzeil (1972). Once the dependent patient role has been adopted, its duration may consist of several stages. Each may be characterized by a more or less typical pattern of (alleged) causes and conditions for medico-social action (treatment, rehabilitation, work resumption, prevention). In the first stage, lasting one till three days, in case of minor ailments work will be resumed after a short period. Except in case of repetitiveness, possibly indicating later psychosomatic disorders, no medical action will be necessary (in the Netherlands). Labor market conditions, motivation, social climate and personnel policy may both affect the decision to report sick and the length of absence. In the next phase (lasting about three days - two weeks) the disorder in human functioning is more or less serious but temporaly, and will usually be followed by a continuation of previous working and living conditions. In the third stage (four weeks - three months) the initial disorder is becoming less important and transforms into a disturbance of functioning, accompanied by somatic and psychic complications and reduction of social 
contacts. After three months (fourth stage) the thread of permanent work incapacity is growing. Attempts to reintegrate are coming into a decisive area. Both the motivation of the individual and the employing firm as well as the socio-medical supervision and efficient treatment become highly relevant. The final stage (after 365 days in the Dutch system) a more or less stable situation of permanent disability has been reached. Old relations have disappeared and resumption of the last job is not expected anymore. Sometimes employment in an adapted function can be achieved.

This schematic overview of the individual work incapacity process particularly regards the Dutch situation. It indicates that spell length and mode of completion are not only being determined by the type of the health problem at the onset of the work incapacity episode. Becoming work incapacitated has its own dynamics. In due time the initial health problem may be surpassed by social isolation and psychosomatic complaints which complicate work resumption. Consequently, we will have to examine whether our countries differ regarding "system-intrinsic" conditions that affect this process.

\subsubsection{An integrated model of sickness absence}

Factors located in various areas and operating on individual, company or societal level may affect the sickness absence process and its outcomes. The abundance of factors have been summarized and related in an integrated model of sickness absence, as demonstrated in Figure 7.2 (cf. Bunnage, 1981; Nyman \& Raitasalo, 1981; Dennerlein \& Schneider, 1985). The factors known to affect sickness absence behaviour have been combined into seven clusters, which are associated with several steps in the micro-process of sickness absence behaviour.

Figure 7.2 An integrated model of sickness absence

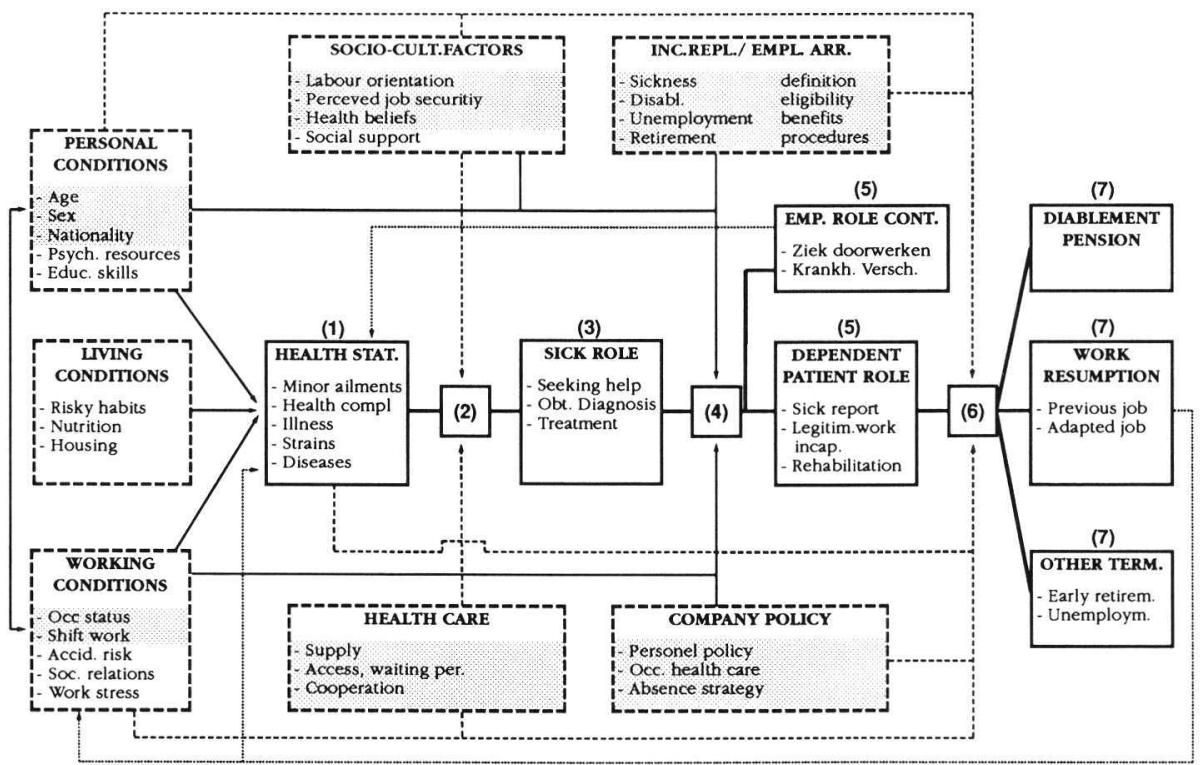


The bealth status of a certain working population is known to have a multifactorial aetiology. Generally speaking the health condition may be affected by

- personal characteristics (e.g. age, skills, psychological resources, biologicalgenetic factors),

- living conditions (e.g. housing, nutrition, life style factors),

- working conditions (e.g. job demands, work stress), as well as

- selection processes (producing "healthy worker effects") due to invalidity and unemployment.

After symptoms are experienced the sickness tolerance threshold may function as the first filter defining whether the sick role will be adopted (by seeking diagnosis, help, treatment). This point of decision is connected with the surrounding social and cultural context as well as the supply and accessability of medical care. The assumption of the sick role may be affected by factors other than health beliefs and attitudes about disease and medical care. Also the access to medical care and its financial consequences (e.g. complete or partial reimbursment of costs of consultations or medicine) may be relevant here.

The next decision to be made, though often going together with adopting the sick role regards the absence tolerance tbreshold. Whether a sick person will accept some health complaints and continue work attendance, or assume the dependent patient role and report sick may depend on elements of various clusters of factors, e.g.

- the seriousness of health reduction;

- socio-cultural factors, e.g. norms regarding legitimate sickness absence, or social support on the work place;

- wage- and benefits arrangements, like definition of work incapacity, legitimation procedures, waiting days, income loss;

- perceived company strategy towards sick employees, during their absence or after work resumption (e.g. disciplinary measures).

The work resumption threshold may be substantially related to socio-economic characteristics like age, education or skills. Also, on a company level disciplinary measures (towards frequently sick) and employee counseling (regarding long term sick) as well as employment practices should be considered (Grosfeld, 1988). Furthermore, here the access to health care facilities (waiting periods) may considerably contribute to the duration of absences. Finally, several aspects of the income replacement systems are expected to influence the length of work incapacity. Not only medical supervision procedures and financial consequences may be taken into account by the employee or "significant others" (physician, employer). Also entitlement criteria or financial and social consequences of leaving the labour market are to be envisaged, namely in case of transfer to alternative income maintenance arrangements, covering other contingencies (disablement, unemployment, early retirement).

\subsection{The cultural context of sickness absence}

Carrying out cross-national studies inevitably makes us aware of culture-bound viewpoints and self-evident notions which show restricted validity when confronted with foreign situations. During our project discussions with helpful data providers, key informants and fellow-researchers often touched more 
general disparities between our countries. Several aspects of our subject matter evoked statements on parallel differences in other areas of society or suggestions on more fundamental cultural variations. Some key words mentioned regarding the Dutch situation were: completeness (e.g. benefits levels), less regulations (e.g. regarding compulsory occupational health care) and multidisciplinarity (e.g. required expertise of personnel managers).

Some socio-cultural factors already have been incorporated in our model and investigation: work-related values and attitudes. Nevertheless, the wider cultural context of our subject may also be taken into consideration, namely by using the outcomes of some recent inquries. Hofstede's study provides a frame of reference to interpret our findings in the light of prevailing attitudes and value orientations in a nation. Hofstede (1980) discerned four cultural dimensions which refer to basic values in a nation. The first dimension, "Power Distance", refers to the acceptance of inequality in organizations and society. "Uncertainty Avoidance" varies across nations vis-à-vis the weight that is being attributed to rule orientation (regulation) in order to avoid uncertain or stressful situations. Prevailing relationships in a culture can, thirdly, be described to their degree of "Individualism". As a fourth aspect a "Masculinity" dimension has been found. This scale stands for the dominant sex role pattern in a society, which, as Philipsen (1988) showed, may be labelled more appropriately by "instrumental" (competition, performance) vs. "expressive" values (cooperation, quality of life). From this inquiry it was concluded Belgian culture is characterized by a very high degree of power distance and uncertainty avoidance. The Netherlands were merely typified by a very low degree of power distance, uncertainty avoidance and masculinity. In German culture in particular instrumental values (masculinity) like achievement and advancement are prevalent but preferences on other dimensions largely resembled the Dutch pattern. Together with Scandinavian countries the Netherlands comprised a set of nations which is characterized by an egalitarian, uncertainty accepting, individualistic but also socially care-taking culture. Belgium and Germany were found to belong to different groups with more emphasis on performance and need for regulation and legislation to avoid uncertainty.

In the discussion of our findings we will explore whether observed crossnational differences might be better understood from our insight in underlying cultural dimensions.

\subsection{Research plan and methods}

The explanatory model attempts to integrate factors and relationships assumed to affect sickness absence in our countries. As a research strategy we will continue the approach from the first part of our investigation, which may be considered as a "most similar systems" design (Przeworski and Teune, 1970). Our countries under study share many political, economic, technical, and climatic characteristics. Such common factors may a priori be considered as ruled out as determinants, so attention can be focused on "intersystemic" differences. As such we try to maximize the number of common characteristics so that the effects of major remaining factors can be studied more systematically. The within-system factors to be controlled for (a postiori) contain two main categories, namely socio-demographic characteristics (population 
composition) and organizational variables, operating on company level (working conditions, employment strategies). After having assessed the effects of these clusters of factors some major macro-level or societal factors will be taken into consideration.

This comparative strategy can only be applied to a restricted number of issues. The analytical model as depicted in Figure 7.2 is clearly "overdetermined": the number of our observations will be too restricted to allow consideration of all relevant factors and relationships (Przeworski \& Teune, 1970). In search for explanations firstly a limited number of independent variables operating on personal level will be considered. Within each national group an analysis of relationships among person-related factors and sickness absence rates. When within-group associations are shown to be sufficiently similar, as a next step the weight of firm- and macro-level factors may be considered.

For the cross-organizational comparisons we will continue our case study approach. We will heavily rely on interviews to be held in the firms under study. Personnel managers, occupational physicians, workers representatives, and supervisors often contributed as key respondents to Dutch sickness absence investigations. Attempt will be made to interview this range of "experts" within each firm and compare facts and opinions on company strategies towards employment and sickness absence, working conditions, etc. Additionally, literature on these subjects and expert's opinions will be examined.

Finally, three major issues on system-or societal level will be compared across nations. Our comparison of social security aspects, the statistical analysis and review of literature indicated firstly, that more insight should be gained in the operation and utilization of income maintenance programmes. Differences in absence taking behavior (spell frequency) may be found to be related to eligibility criteria, whereas a high proportion of sickness absence duration may relate to the role of medical supervision procedures or economic incentives. Diverging levels of invalidity pension transfer also suggest effects of different programme requirements or dissimilar labour market conditions. Therefore the application of benefit arrangements regarding sickness, disablement and nonhealth-related risks (unemployment) will take a central position in the system comparison.

Further two issues with a probably weaker methodological basis will need consideration. On the one hand aspects of health condition and health behaviour in our nations under study will be regarded as differences in health status and illness behaviour may contribute to contrasting sickness absence levels. On the other hand work-related values and attitudes will be compared, as they affect work-related behavior, job satisfaction and, consequently, sickness absence.

Table 7.2 Overview of data collection methods applied

\begin{tabular}{lllcl}
\hline Focus & $\begin{array}{l}\text { Sickness absence } \\
\text { data collected }\end{array}$ & $\begin{array}{l}\text { Company } \\
\text { interviews }\end{array}$ & $\begin{array}{l}\text { Sources } \\
\text { (Cross-)national } \\
\text { studies }\end{array}$ & Statistics \\
\hline $\begin{array}{l}\text { Person-bound } \\
\text { factors }\end{array}$ & $\mathrm{X}$ & $\mathrm{X}$ & $\mathrm{X}$ \\
$\begin{array}{l}\text { Cross-organizational } \\
\text { comparison }\end{array}$ & $\mathrm{X}$ & $\mathrm{X}$ & $\mathrm{X}$ & \\
\begin{tabular}{l} 
Societal conditions \\
\hline
\end{tabular} & $\mathrm{X}$ & $\mathrm{X}$ & $\mathrm{X}$ \\
\hline
\end{tabular}


The clusters of factors on system-level may be approached by using available studies and appropriate social security-, labour- and health-statistics (cf. Table 7.2). For validation purposes feedback from local experts will be needed, a procedure which also proved to be highly rewarding in an investigation carried out in parallel (cf. Andriessen et al., 1983). Notwithstanding, the realisation of our objectives will heavily depend on the cooperation of firms, validity of measurements and availability of statistics.

\subsection{Summary}

Our overview of mainstreams in Belgian, German and Dutch sickness absence research showed remarkable contrasts in the extensiveness of interest. Notwithstanding, it was concluded that several aspects of sickness absence are common for employees in all countries. This observation not only applies to the association of socio-demographic factors (age, sex, nationality) to sickness absence measures. Also many similarities were noted regarding the findings on relationships of work-related aspects (labour relations, job content, supervisory methods, work stress). It was decided to apply a decision theoretical approach for our further inquiry as it comprises both health related factors (objective and subjective state of health) and social norms and perceptions (as to reporting sick) as well as firm and social security factors.

The findings and theoretical notions from these sickness absence investigations have been integrated in an analytical model of sickness absence. This explanatory frame of reference incorporates variables and relationships on three levels of analysis: individual (personal factors), firm (strategies), and national system (comprising cultural, social security and employment conditions). Factors and processes have been indicated to affect the sequence of events and decisions which constitute sickness absence behaviour. Given a certain health condition in due course three decisions have to be made. Firstly, the employee has to decide whether or not he will adopt the sick role (and obtain diagnosis, receive treatment). Secondly, conditioned by the seriousness of ailment, the employee may or may not report sick and adopt the dependent patient role. Finally, the employee or a social insurance doctor decides resumption of the employee role (in case of recovery) or adoption of the status of being disabled, unemployed or retired.

In our research design only a limited number of relationships and factors will be examined, namely insofar as sufficiently reliable data can be found. Factors operating on societal level will be examined after having assessed the effects of variables on lower levels (firm, individual). To that end our sickness absence data will be further analysed, and interviews will be held in the firms under study. Recent literature and some feedback-interviews with local experts will be indispensable to understand our findings within their context. 


\section{SELECTED POPULATION}

\section{CHARACTERISTICS AND SICKNESS ABSENCE}

\subsection{Introduction}

In our analytical model personal factors, living conditions and working conditions are considered as major sets of factors affecting the health status and work incapacity ("dependent patient role") in a population. For a small selection of variables, indicating personal and work related factors, our inquiry allows a close cross-national comparison of relationships and risk groups within each national group. In Chapter 5 and 6 we already regarded three major factors (age, sex, occupational status); now some more variables will be included in our inquiry.

Firstly, for each variable we will summarize research findings and their interpretation in each country. This will be compared to the results of our analysis to see whether our conclusions match local findings, and to ascertain that our selection of firms is not heavily biased. Subsequently, for each national group a multivariate analysis will be made to account for interactions between variables. This step may result in a comparison of basic factors and relationships across groups. Finally, an over-all multivariate analysis may show how far all variables observed attribute to cross-national sickness absence differences. Within the limits imposed by our data collection method (cf. Chapter 4) we will primarily deal with variables measured in all firms. "Department" and "Wage group" were excluded from further analysis as a reconstruction of new variables applicable for all employees was shown to be complicated. So our analysis will be focussed on three socio-demographic variables (age, sex, nationality) and three work-related variables (occupational status, length of service and day/shift work). Finally, "turnover" (stayers and leavers) and its relationship to sickness absence will be included in our analysis. This aspect will be considered in more detail in the cross-organizational comparison.

\subsection{Literature suggests several similarities}

As the age structure of a population considerably affects its health status most studies account for this variable. We already considered this variable (as well as sex, occupational status) in Chapter 5 , so our review can be short. In his review of over 300 studies Smulders (1984a) found age (groups) mostly being inversely related to spell frequency. Also quite unanimously spell duration showed to increase with age. The inquiries in our countries indicate, with exception of a few Belgian sources, similar associations of age to number of spells, days lost as well as spell duration. Most authors agree that the interpretation of these relationships is less obvious, however. Cross-sectional comparisons of younger and older employees do not only refer to biomedical factors (state of health) but also to cultural (value orientations, life style) and labor 
market differences (skills and qualifications). Also selection processes may affect age-specific absence rates and probably account for lower rates in the oldest age group (cf. Chapter 5; Maib, 1981; Pfaff et al., 1985).

Another variable already being accounted for in our study is sex, as male and female employees usually show different sickness absence patterns. The findings regarding the associations with absence rates are not unanimous, however. Smulders (1984b) noted both positive and negative relationships with days lost and average duration. For spell frequency research findings seem to be more congruent, indicating female employees report sick more often than males.

Higher severity rates in female workers may be explained by biological conditions (constitution, confinement periods and maternity leave), differences in job structure (overrepresented in repetitive, poorly paid jobs), non-work related stress (due to housework and kinship responsability). Authors within a country sometimes differ considerably regarding evidence or arguments on the relevance of these "confounders". Belgian sources indicate female employees being more days absent due to sickness than men, but according to most German inquiries more days are being lost by male personnel (Schlegel, 1982; Lefelmann, 1984). Macroscopic statistics in the Netherlands demonstrate both higher frequency and severity rates in female employees. More detailed comparisons indicate that type of work (sector) or maternity leave periods may account for most of the differences in days lost between male and female employees (Brouwer \& Vrijhof, 1987; Van Engers, 1987). It may be concluded that the variable sex seems to yield dissimilar relationships to severity rates, whereas in all countries female employees show more spells, compared to men.

A characteristic sometimes attracting special attention is nationality of employees, or more concretely: sickness absence in migrant workers. The balance of evidence and indications shows a rather consistent picture. With one exception (Klaric, 1974) Belgian sources, controlling for age and type of work showed higher severity rates in migrant workers compared to native personnel (Peeters, et al., 1982). German statistics and inquiries (cf. Schlegel, 1982; Salowsky, 1983) also indicated migrant workers to be more work incapacitated than employees with a German nationality. A few Dutch studies comparing employees with similar working conditions or wage groups consistently showed higher severity rates and longer spell lengths in Mediterranean employees compared to their Dutch colleagues (Jansen, 1983; Kramer-van der Zee \& Verbaan, 1982). Both Belgian, German and Dutch sources attribute these higher rates to work-related health risks (being mostly employed in semiskilled or unskilled occupations with environmental hazards), cultural factors (e.g. feeding pattern, lodging conditions, value orientations) or climatic factors.

Since many years occupational status lost much of its labour-judicial meaning in the Netherlands, however still being an important socio-economic characteristic in most other countries and therefore hardly lacking in sickness absence statistics. Findings on relationships to sickness absence are quite congruent across countries: manual employees consistently show 50-100\% higher rates than staff personnel (e.g. Henderickx, 1985; Maib, 1981; Vrijhof, 1987). This 
work-related dichotomy may indicate serious differences in physical work stress and, in many countries also, sick-pay provisions and job security. A detailed analysis of work and individual variables showed that sickness absence differences between manual workers and staff may not only be attributed to type of work. Differences decreased substantially when being accounted for age, sex, qualification and shift work (Vrijhof, 1987a).

Another characteristic often measured and analysed regarding sickness absence is length of service (seniority). Not only a contamination with age complicates the drawing of conclusions but also the restricted validity of this indicator. It is quite unclear whether this variable stands for psychological aspects (e.g. firm loyalty), job characteristics (e.g. creativity) or selection processes ("healthy worker effect").

Not only on a theoretical but also on an empirical level this variables relationship to sickness absence is uncertain. Studies mostly indicate a $\mathrm{N}$-shaped curve with absence percentage, when accounted for age. Adriaenssens (1985) observed increasing length of service to go with falling spell frequencies and growing absence durations, but other sources noted opposite associations. Maib (1981) noted in German firms a stabilization and increase of "never sick" when seniority ascends. Dutch sources also lack unanimous findings, but some curvilinear relationship to spell frequency and severity has been suggested, showing highest rates before the 10th year of service (Vrijhof \& Andriessen, 1986).

Several studies compared shift and day workers regarding sickness absence differences, but results are contradictory (Smulders, 1984a). Belgian sources suggest higher severity rates in shift workers compared to day workers (Lebeer, 1981; Adriaenssens, 1985). Maib found similar differences, moreover indicating a higher frequency of short spells in day workers. Dutch sources confirm this pattern of differences: day workers show considerably lower severity rates and shorter spell durations than shift workers (Vrijhof, 1987). Workers in a two-shift-system take less sickness absences but on average spells last more days than in three-shift-workers. The interpretation of these findings allows some variation: whereas some sources refer to expected higher loyalty and feelings of indispensability in shift workers to explain lower frequencies, other inquiries point to work stress, whereas health-related selection processes ("healthy worker effects") may obscure these effects.

Finally, some inquiries threw light on the importance of turnover and selection processes for absence rates. The proportion of stayers and leavers may account for differences in sickness absence between firms or groups, as "leavers" show higher absence rates than "stayers". Recently, Adriaenssens (1985) and Vrijhof (1987a) found 2-4 times higher sickness absence percentages in leavers compared to stayers. On spell frequency differences were less extreme, indicating that leaving the firm in the Netherlands in particular is associated with having many absence days. 


\subsection{Empirical findings show considerable agreement}

In Section 6.1.2 we already noted for spell frequency and severity rates the expected associations with age (groups). Only German severity rates showed a somewhat deviant pattern as lowest rates were not found in the youngest age group but in those aged 36-45. Additionally, we note that with rising age the number of short spells falls considerably. Furthermore, the frequency of long term absences rises substantially with age in particular in the German and Dutch group (cf. Figure 8.1). Belgian employees show a remarkably lower rise in frequency of long term spells.

Severity rates in younger age groups are mostly due to a lot of short spells $(60-70 \%)$ and relatively few long term spells. In oldest employees few absences up to one week occur, whereas about $300 \%$ more long term spells are noted compared to the youngest colleagues.

Figure 8.1 Average annual short and long term frequency rates by age in three national groups (1980 and 1981)
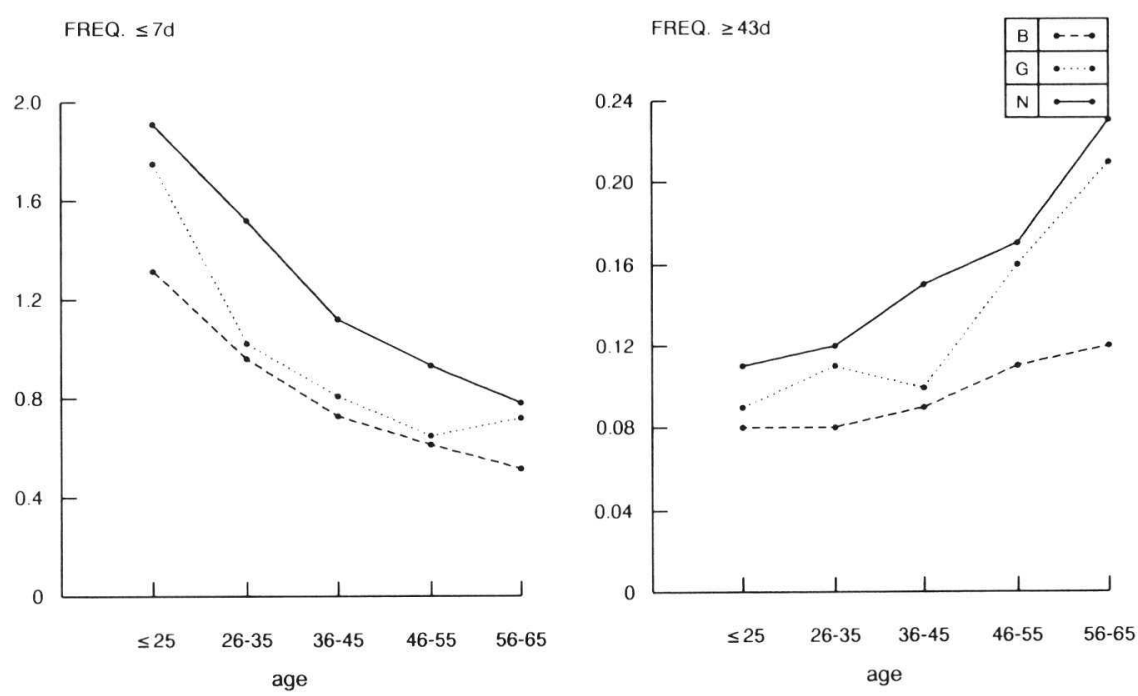

In the first part of our analysis we already noted that sex is quite consistently associated with absence rates (cf. Table 6.4). Male employees take less absences (in each duration class) and on average resume work earlier than female personnel. Vis-à-vis absence frequency our findings are congruent with expectations based on local sources. For severity rates we found more unanimous conclusions than literature previously suggested. However, in Belgian and German firms absence differences are considerably larger than in Dutch firms.

Previously it has been stated that the relationship observed for sickness absence and sex may be affected by interactions from other variables. Table 8.1 illustrates this assumption in a twofold way, comparing the age structure and sex- 
Table $8.1 \quad$ Relative age distribution and severity rates by sex and age in the Belgium and Dutch group (1980, 1981)

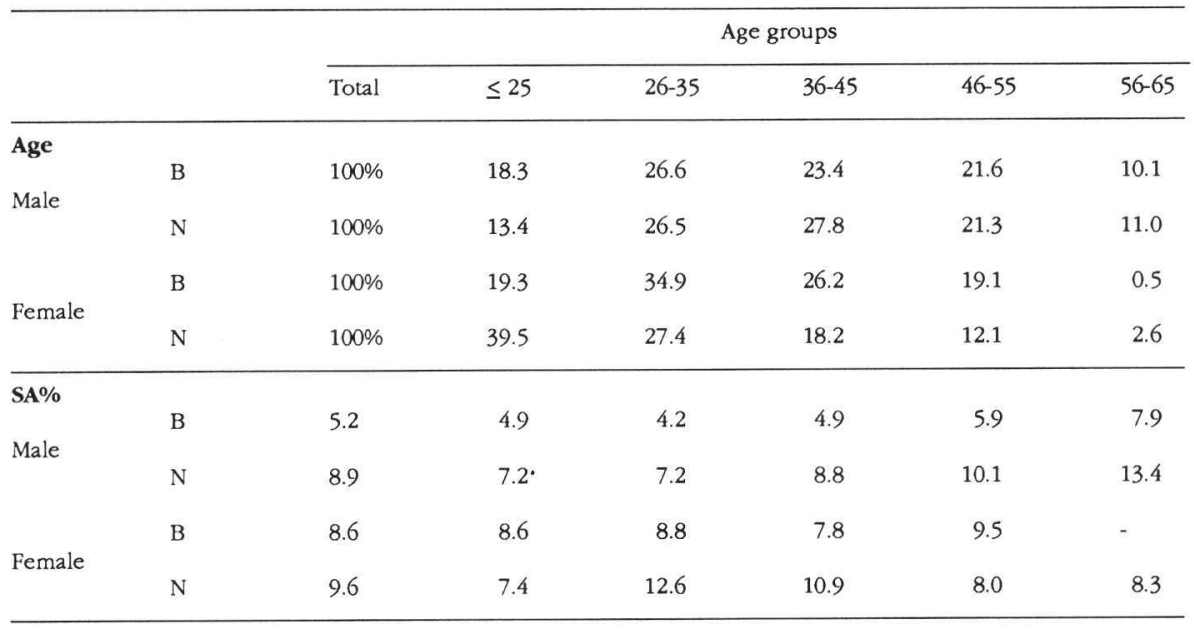

specific absence rates in the Belgian and Dutch group. Firstly, in the Dutch group female employees show a completely different age structure compared to male personnel. About $40 \%$ of female employees are under 25 years, a proportion steeply falling with age. As male employees do show a more "normal" age distribution, this variable affects the direct comparison of male and female sickness absence. However, this variable will hardly contaminate Belgian sex specific absence rates, as both categories show a similar age distribution. Secondly, in the Dutch group up to 45 years female employees exceed male absence rates. In the Belgian group, for both sexes, age shows a similar relationship with absence rates, and female workers consistently demonstrating higher severity rates than males. Surprisingly, in our Belgian group females aged 25-35 years do not show higher rates due to maternity leave periods etc. as in Dutch female employees. It may be concluded that interrelationships do not seem to be similar for all national groups under study.

A comparison of native and migrant employees within our groups confirms conclusions from previous studies: both frequency and duration of spells are highest for the latter category (cf. Table 8.2). Our figures indicate highest differences between these categories are found in the Dutch group. For all national groups a similar pattern is obvious: compared to native personnel migrant workers show equal (B) or substantially less short term spells but much more absences lasting over six weeks. Within several clusters it could be observed that absence differences reduced when controlling for wage group. So the unequal job structure in these categories does considerably affect their absence rates.

The second category of population characteristics comprises work related variables like occupational status, length of service, shift work and labour turnover. Chapter 5 and 6 unanimously confirmed results from local sources 
on occupational status indicating highest absence rates are being found in manual workers (cf. Table 6.4). On closer inspection our data indicate these differences may predominantly be attributed to comparatively more medium and long term absences (cf. Table 8.3).

Table 8.2 Average annual sickness absence rates by duration class for native (Nat) and migrant (Mig) employees in three national groups (1980 and 1981)

\begin{tabular}{|c|c|c|c|c|c|c|c|c|c|c|}
\hline & & $\begin{array}{l}\text { No. of } \\
\text { Persons }\end{array}$ & $\begin{array}{l}\text { Total } \\
\text { sa \% }\end{array}$ & freq. & $\begin{array}{l}\text { Spells } \\
1-7 \mathrm{~d} . \\
\text { sa } \%\end{array}$ & freq & $\begin{array}{l}\text { Spells } \\
8-42 \mathrm{~d} . \\
\text { sa } \%\end{array}$ & freq. & $\begin{array}{l}\text { Spells } \\
43-365 \\
\text { sa } \%\end{array}$ & $\begin{array}{l}\text { d. } \\
\text { freq. }\end{array}$ \\
\hline \multirow{2}{*}{ B } & Nat. & 2157 & 5.7 & 1.39 & 1.1 & 0.86 & 2.1 & 0.44 & 2.5 & 0.09 \\
\hline & Mig. & 88 & 7.7 & 1.60 & 1.2 & 0.91 & 2.7 & 0.56 & 3.8 & 0.13 \\
\hline \multirow{2}{*}{ G } & Nat. & 3212 & 8.3 & 1.86 & 0.9 & 0.94 & 4.0 & 0.79 & 3.4 & 0.13 \\
\hline & Mig. & 519 & 10.6 & 2.11 & 0.8 & 0.68 & 6.1 & 1.28 & 3.7 & 0.15 \\
\hline \multirow{2}{*}{$\mathrm{N}$} & Nat. & 3102 & 8.1 & 2.07 & 1.5 & 1.34 & 2.7 & 0.60 & 3.9 & 0.13 \\
\hline & Mig. & 386 & 16.4 & 2.73 & 1.0 & 0.79 & 8.2 & 1.60 & 7.2 & 0.28 \\
\hline
\end{tabular}

Table 8.3 Average annual severity and frequency rates by occupational status and duration class in three national groups (1980 and 1981)

\begin{tabular}{|c|c|c|c|c|c|c|c|c|c|c|}
\hline & & \multirow[t]{2}{*}{$\begin{array}{l}\text { No. of } \\
\text { Persons }\end{array}$} & \multicolumn{2}{|l|}{ Total } & \multicolumn{2}{|c|}{$\begin{array}{l}\text { Spells } \\
1-7 \mathrm{~d} \text {. }\end{array}$} & \multicolumn{2}{|c|}{$\begin{array}{l}\text { Spells } \\
8-42 \mathrm{~d} \text {. }\end{array}$} & \multicolumn{2}{|c|}{$\begin{array}{l}\text { Spells } \\
43-365 \mathrm{~d} .\end{array}$} \\
\hline & & & sa $\%$ & freq. & sa $\%$ & freq. & sa \% & freq. & sa $\%$ & freq. \\
\hline \multirow{2}{*}{ B } & Staff & 611 & 3.2 & 1.01 & 0.9 & .73 & 1.0 & .23 & 1.3 & .05 \\
\hline & Man. & 1634 & 6.7 & 1.55 & 1.2 & .91 & 2.5 & .53 & 3.0 & .11 \\
\hline \multirow{2}{*}{ G } & Staff & 941 & 5.2 & 1.59 & 0.9 & 1.07 & 2.4 & .45 & 2.0 & .07 \\
\hline & Man. & 2791 & 9.8 & 2.00 & 0.9 & .84 & 5.0 & 1.01 & 3.9 & .15 \\
\hline \multirow{2}{*}{$\mathrm{N}$} & Staff & 1767 & 6.0 & 1.78 & 1.3 & 1.30 & 1.7 & .38 & 3.0 & .09 \\
\hline & Man. & 1711 & 12.1 & 2.52 & 1.5 & 1.26 & 4.9 & 1.07 & 5.6 & .20 \\
\hline
\end{tabular}

Before, the inventory of sources indicated that findings on the association of length of service to sickness absence were not unanimous within and between countries (cf. Section 8.1). Our analysis does not demonstrate consistent results either (cf. Figure 8.2). In two groups (B, G) after one year of employment absence rates are quite stable whereas Dutch workers employed 5-10 years show highest percentages days lost due to sickness.

In Belgian firms spell frequency regularly drops with rising length of service, but in both other groups this tendency starts after two years of engagement. 
Figure 8.2 Average annual sickness absence rates by length of service in three national groups (1980 en 1981)

S.A. \%

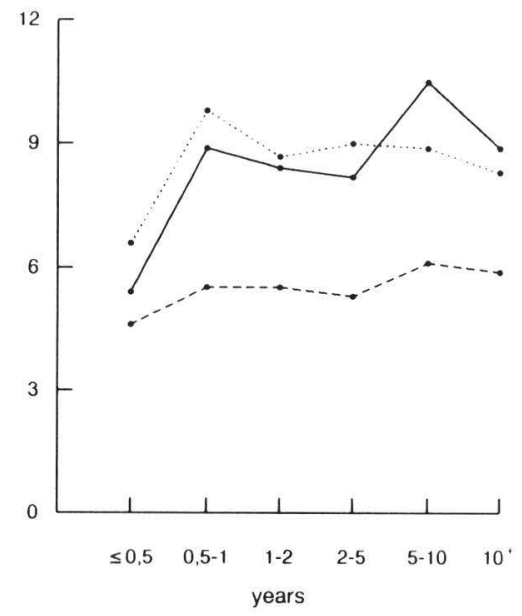

FREQ
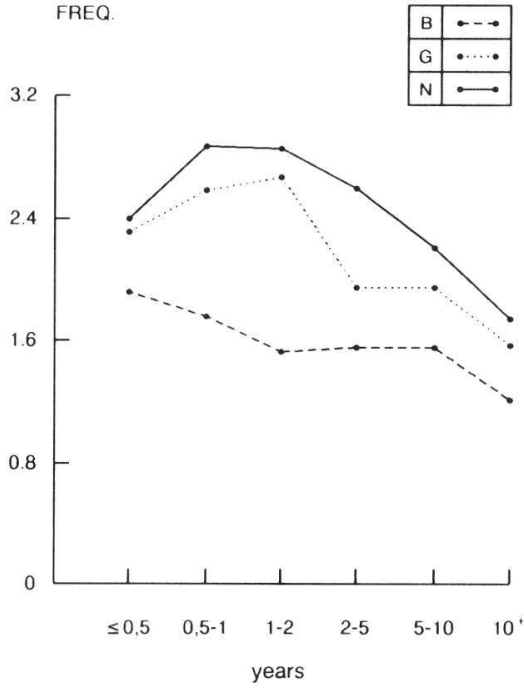

Furthermore, severity rates in Belgian and German firms are hardly affected by seniority, whereas Dutch figures show considerable variations with a rising tendency. Generally our findings confirm inconsistency already noted in local sources.

In our investigation day and shift workers follow the pattern of sickness absence differences reported before (cf. Figure 8.3). Day workers generally report sick less than shift workers, who also show higher absence percentages. Both for the Belgian and German group employees working two shifts show considerably more sickness absence than three shift workers, which seems to be primarily due to substantially more long term absences. In the Dutch group, however, shift type hardly differentiates absence rates, and most spells per person are being noted in three shift workers. Summarizing it may be concluded that our findings mostly fit to previous conclusions.

Finally, our analysis confirms findings in Belgian and Dutch studies on turnover and sickness absence: compared to stayers in all groups, leavers showed $30-70 \%$ higher frequency rates (largest differences being noted in the Belgian and German group). However, in all groups severity rates for leavers were over three times as high as in stayers, indicating especially persons with long term absences terminated employment in our firms. This variable will be considered more closely in Section 9.6 comparing company-related variables like policies towards sickness absence. 

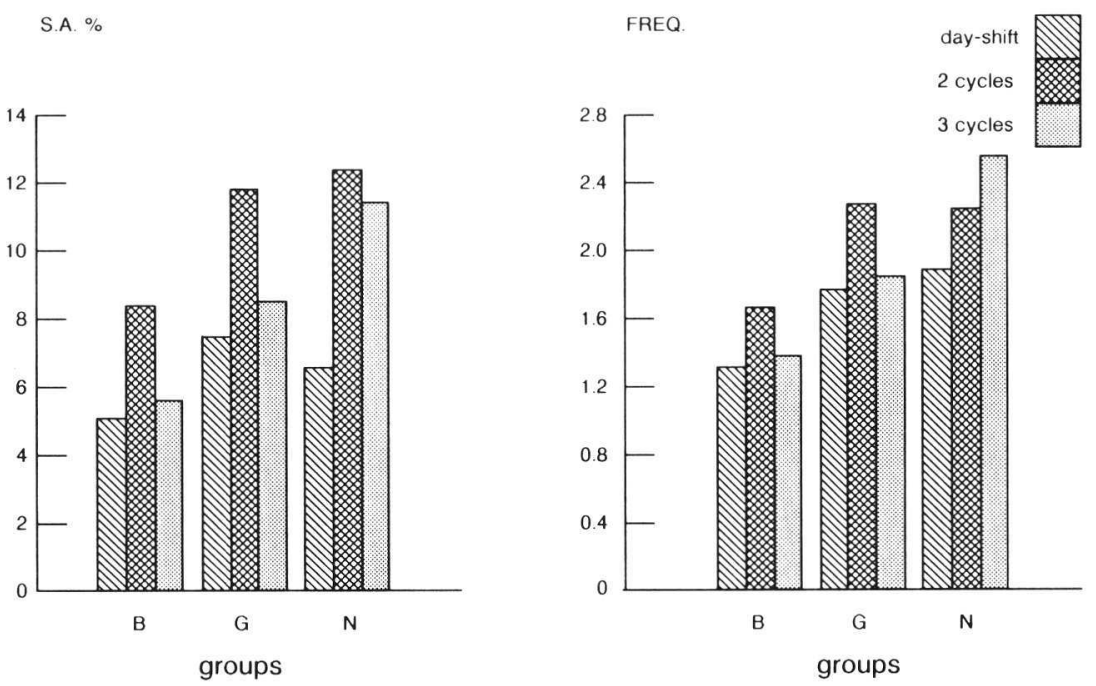

Resuming our findings we may note a considerable consistency in expected and observed relationships of population characteristics to absence rates. Only for the variable "length of service" contradictory results from literature have been confirmed in this investigation. For other variables with ambiguous relationships to absence rates, more consistent results were found here. Notwithstanding, in more detail some remarkable differences were shown between our groups, which may be due to interaction effects:

- Belgian employees aged over 45 show a remarkably low number of long term spells;

- differences in absence-rates between male and female employees are relatively small in the Dutch group;

- also in this group migrant workers do exceed native employees absence rates much more than elsewhere;

- in the Dutch group three-shift workers show absence rates comparable to those in two-shift-workers. In other groups three-shift workers are nearly similar to day workers vis-à-vis their absences.

So far our analysis did not show that sickness absence in our selection of firms and employees is deviant from patterns observed in their countries. Furthermore, across national groups highly consistent results have been found regarding population variables and sickness absence indicators. And besides, for all variables and absence indicators the cross-national sickness absence rankorder examined in Chapter 6 persisted.

\subsection{A multivariate comparison}

Our previous bivariate analysis gave an insight in the dispersion of sickness absence over several population characteristics, indicating categories of 
personnel with high or low absence rates. It may not be concluded, however, that relationships observed, within and across national groups do indicate main effects on sickness absence. Socio-demographic and work-related variables may be intertwined, showing interactions which bias bivariate relationships. For instance the remarkably small differences in absence rates between males and females in the Dutch group may be due to differences in age structure of these categories in the groups compared. Also different job structures (e.g. females occupying a higher proportion of staff or clerical jobs) compared to Belgian and German colleagues may affect this relationship.

\subsubsection{Aim, data and method}

This section contains the results of a multivariate analysis applied for each national group to account for interaction effects. Consequently, for each national group a more valid insight in the pure "effects" of population characteristics on absence may be obtained. By applying the same analysis to each national group the comparison of outcomes may make us more aware of general mechanisms (indicated by same high or low risk groups in our three populations) or specific factors (when risk groups are "unique" for one national group). After identifying the main factors within each group, the investigation will be completed by a multivariate analysis of sickness absence differences between groups. Compared to the standardization techniques applied before, this inquiry accounts not just for three but for all variables measured, and it may reveal least biased cross-national differences.

Seven variables have been selected to investigate their multivariate relationship with sickness absence percentage and spell frequency. "Nationality" fell out of further analysis because of the very small percentage of migrants in Belgian workforces (4\%). To find out whether a company-bound effect might have influenced our rates the variable "sector" has also been included in the analysis as a crude indicator of specific firm-related (organizational) factors.

The degree of relationship between a single variable and sickness absence controlling for other variables is usually measured by applying some (log-)linear regression analysis. Vis-à-vis sickness absence, however, this technique has several restrictions:

- Regression analysis only represents linear or ordinal associations, whereas many variables show a curvilinear relationship with sickness absence (e.g. length of service in the German and Dutch group; cf. Figure 8.2);

- This technique is less appropriate to nominal variables; in our study, however five independent variables have this level of measurement.

Recently developed regression techniques provide an alternative as they are less restrictive and may be used with nominal scale variables and non-linear associations. In this study a Canonical Analysis using Alternating Least Squares (CANALS) will be applied, which has been developed by the department of Data Theory of the Social Faculty of Leiden University (Van der Burg, 1985). This (non-linear) canonical correlation analysis maximizes the canonical correlation between two sets of (one or more) variables, by optimal scaling of the variable categories as well as giving optimal weights to the rescaled variables.

CANALS comprises two alternating steps. Firstly, a transformation is made of 
the original category-scores $(1,2,3$, etc.) of the variables into optimal quantifications. (1) Secondly, weights for the rescaled variables are calculated that maximize the canonical correlation between the two sets of variables. The algorithms of both steps are iterative procedures (related to each other) that stop when no more improvement can be accomplished. If one of the two sets contains only one variable, CANALS is formally equal to (non-linear) regression analyses. In the first step the categories of the variables are rescaled, and the second step is a classical linear regression analysis of the rescaled independent variables on the rescaled dependent one.(2)

To apply CANALS the variables of both sets of which the canonical correlation is maximized must be divided into a limited number of categories. For many variables this categorization is obvious (e.g. occupational status, sex, sector); for others a reduction of values into categories has to be made (e.g. age, length of service, severity rates).

In the first step all the categories of the 'independent' set are -in essencetreated as separate dichotomous variables in a regression analysis. The weights they finally get to maximize the multiple correlation, are in fact their optimal quantifications or rescaled values. These optimal quantifications can be projected on a vector through the (ordinal rescaled) categories of the dependent variable, which is in this "case the sickness absence indicator. The magnitude of these projections depends partly on the canonical correlation of the two sets. These so-called projections of the category-quantifications on the axis of the second set (second canonical variate) are proportional to the more or less independent correlations between categories and the absence measure. These projections indicate whether the single category, with minimal contamination of other categories(3), corresponds with a relatively higher, lower or average sickness level. Now it may be shown that originally 'ordinal' variables (like length of service) loose their ordinal ranking in relation to the dependent variable (sickness absence), indicating curvilinear relationships. Consequently, the sign and magnitudes of the projections allow high and low risk groups to be detected, which are minimally contaminated by other categories.

The upper and lower boundary of these projections are the minimum and maximum of the quantifications of the categories of the variable in the second set. To compare the projections in several CANALS-solutions in which only the objects or periods are different but not the variables and categories (e.g. the same analyses for different countries), these upper and lower bounds can be standardized to -1.00 and +1.00 while rescaling the projections proportional to the original upper and lower bounds.

The variables and their categories selected for the CANALS analysis were:

- age: five categories (aged up to 25 years, 26-35 years, 36-45 years, 46-55 years, 56 years and more);

- sex: two categories (male, female);

- occupational status: two categories (staff, manual);

- length of service: four categories (0-2 years, 2-5 years, 5-10 years, over 10 years);

- type of shift: four categories (day work, two-shift, three-shift, rest);

- turnover: two categories (stayer, leaver); 
- sector: four categories (Paint, Margarine, Frozen Food, Metal);

- sickness absence percentage: five categories (chosen for each national group so that employees were regularly dispersed);

- sickness absence frequency: five categories (for each national group defined by regarding a regular spread of persons).

We firstly will consider whether our groups contain similar risk categories.

\subsubsection{Common sickness absence factors}

For each national group Table 8.4 gives an overview of high and low risk categories for absence frequency (1980), which are highly comparable for both years. Both in the Belgian and German group "leaving the firm", and "being young" are more associated with taking extremely frequent absences then in the Dutch group, which only shows one minor risk category (engaged 2-5 years).

Table 8.4 Relatively bigh and low risk categories regarding sickness absence frequency in three national groups (1980)

\begin{tabular}{|c|c|c|c|c|}
\hline Group & $\begin{array}{l}\text { Highest categories ov } \\
\text { mean freq.(max.: }+1\end{array}$ & & $\begin{array}{l}\text { Lowest categories ur } \\
\text { mean freq. (min.: - }\end{array}$ & \\
\hline B & $\begin{array}{l}\text { Leavers } \\
\text { Aged under } 25 \text { years }\end{array}$ & $\begin{array}{l}.20 \\
.16\end{array}$ & $\begin{array}{l}\text { Staff } \\
\text { Aged } 45-55 \\
\text { Aged over } 56 \text { years } \\
\text { Aged 36-45 years } \\
\text { Engaged } 2-5 \text { years } \\
\text { Frozen Food sector }\end{array}$ & $\begin{array}{l}-.37 \\
-.37 \\
-.29 \\
-.18 \\
-.15 \\
-.14\end{array}$ \\
\hline G & $\begin{array}{l}\text { Leavers } \\
\text { Aged under } 25 \text { years }\end{array}$ & $\begin{array}{l}.25 \\
.24\end{array}$ & $\begin{array}{l}\text { Aged } 45-55 \text { years } \\
\text { Staff } \\
\text { Aged over } 56 \text { years }\end{array}$ & $\begin{array}{l}-.23 \\
-.22 \\
-.19\end{array}$ \\
\hline $\mathrm{N}$ & Engaged $2-5$ years & .12 & $\begin{array}{l}\text { Aged over } 56 \text { years } \\
\text { Staff } \\
\text { Aged } 45-55 \text { years } \\
\text { Engaged } 0-2 \text { years } \\
\text { Margarine sector }\end{array}$ & $\begin{array}{l}-.25 \\
-.18 \\
-.16 \\
-.15 \\
-.15\end{array}$ \\
\hline
\end{tabular}

For all national groups it is noted that personnel categories with relatively low spell frequencies mostly may be indicated by older age classes and by type of work (staff jobs). Cross-group comparison shows striking similarities, all indicating that high risks, and in particular, low risk categories mainly are associated with sociodemographic categories. Quantifications showed for the Dutch group a mainly linear negative association of age to spell frequency. In the German group a negative ordinal relationship has been noted, whereas Belgian data suggested a weaker, non-ordinal association.

Categories with comparatively high or low severity rates in the German and Dutch group also were fairly similar for 1980 and 1981, though sometimes the internal ranking within the (maximum and minimum) groups have changed. Highest or lowest categories in the Belgian population were only partly identical for both years; e.g. Belgian "leavers" just showed "average" absence rates in 1981, but higher rates in 1980. Generally speaking the Belgian quantifications 
indicate that with an exception of "staff", there are not as many outspoken risk categories as in both other groups.

Table 8.5 Relatively high and low risk categories regarding sickness absence severity in three national groups (1980)

\begin{tabular}{|c|c|c|c|c|}
\hline Group & $\begin{array}{l}\text { Highest categories } \\
\text { mean abs. } \% \text { (max. }\end{array}$ & & $\begin{array}{l}\text { Lowest categories un } \\
\text { mean abs.\% (min.: - }\end{array}$ & \\
\hline B & $\begin{array}{l}\text { Females } \\
\text { Leavers } \\
\text { Two-shift workers }\end{array}$ & $\begin{array}{l}.19 \\
.16 \\
.13\end{array}$ & $\begin{array}{l}\text { Staff employees } \\
\text { Three-shift workers }\end{array}$ & $\begin{array}{l}-.40 \\
-.12\end{array}$ \\
\hline G & $\begin{array}{l}\text { Leavers } \\
\text { Two-shift workers }\end{array}$ & $\begin{array}{l}.28 \\
.16\end{array}$ & $\begin{array}{l}\text { Staff employees } \\
\text { Day workers }\end{array}$ & $\begin{array}{l}-.40 \\
-.14\end{array}$ \\
\hline $\mathrm{N}$ & $\begin{array}{l}\text { Two-shift workers } \\
\text { Metal sector } \\
\text { Manual workers } \\
\text { Leavers }\end{array}$ & $\begin{array}{l}.28 \\
.21 \\
.19 \\
.18\end{array}$ & $\begin{array}{l}\text { Staff employees } \\
\text { Day workers } \\
\text { Engaged } 0-2 \text { years } \\
\text { Margarine } \\
\text { Aged up to } 25 \text { years }\end{array}$ & $\begin{array}{l}-.33 \\
-.25 \\
-.23 \\
-.21 \\
-.18\end{array}$ \\
\hline
\end{tabular}

Notwithstanding, many similarities can be observed regarding high or low risk groups in employees from Belgian, German and Dutch firms. "Leavers" and "Two shift workers" show to be highest risk groups in all populations, whereas female employees also are a high risk group in Belgian firms. In all national groups low absence percentages are predominantly associated with being employed as staff personnel. Furthermore, in the Dutch group low sickness absence risks are more differentiated: more categories are associated with low severity rates than in both other populations. Also only the Dutch group shows (two) company related high and low risk categories, indicating that some single organizational characteristic or process has an effect on sickness absence. Finally, we may note that both high and low categories generally are associated with work-related variables; only a few exceptional categories are defined as person-related characteristics (females; aged up to 25 years).

The relative weight of each variable for the sickness absence risk may be summarized by the results of the regression analysis applied to the optimally scaled variables (the second step in CANALS-analysis) in each group (cf. Table 8.6).

It must be emphasized that the second part of CANALS provides partial (and multiple) correlations of rescaled variables with the dependent variable. If for instance age would have a curvilinear relation with sickness absence the strength of this relation is not due to an ordinal relationship. Actually the linear relation might be zero, while a reordering of the categories of age can change the correlation into a quite strong one.(4) Therefore, when interpretating the results, the rescaled values of the categories must be taken into account.

Firstly, it may be concluded for all national groups "age" being the main determinant of sickness absence frequency: rising age goes with reduction of number of sickness absences. For the Belgian and German population only one more factor exerts a substantial effect on spell frequencies, namely "turnover": 
Partial and multiple correlations of (rescaled) variables to frequency and severity rates in three national groups 1980 (1981)

\begin{tabular}{|c|c|c|c|c|c|c|c|c|c|c|c|c|}
\hline \multirow[b]{2}{*}{ Variable } & \multicolumn{11}{|c|}{ Partial Correlations } & \multirow[b]{2}{*}{$\mathrm{N}$} \\
\hline & \multicolumn{3}{|c|}{$\begin{array}{l}\text { Spell frequency } \\
\text { B }\end{array}$} & \multicolumn{2}{|l|}{ G } & $\mathrm{N}$ & \multicolumn{3}{|c|}{$\begin{array}{l}\text { Sickness Absence \% } \\
\text { B }\end{array}$} & \multicolumn{2}{|l|}{ G } & \\
\hline Age & -.22 & $(-.15)$ & -.22 & $(-.19)$ & -.14 & $(-.18)$ & $.03^{*}$ & $(.05)$ & .08 & $(.08)$ & .09 & $(.04)$ \\
\hline Sex & .09 & $(.09)$ & .09 & $(.13)$ & .06 & $(.07)$ & .15 & $(.11)$ & .08 & $(.12)$ & .01 & $\left(.01^{*}\right)$ \\
\hline Occ. Status & .14 & $(.14)$ & .09 & $(.10)$ & .17 & $(.17)$ & .23 & $(.18)$ & .21 & $(.21)$ & .28 & $(.27)$ \\
\hline Length of Service & $.04^{*}$ & $\left(.00^{*}\right)$ & .04 & $(-.13)$ & -.10 & $(-.18)$ & .04 & $(.12)$ & $.02^{*}$ & $\left(.03^{*}\right)$ & .08 & $(.06)$ \\
\hline Day/shift work & $.02^{*}$ & $(.05)$ & .11 & (.13) & .11 & $(.16)$ & .11 & $(.05)$ & .16 & $(.20)$ & .24 & $(.25)$ \\
\hline Turnover & .19 & $(.07)$ & .21 & $(.12)$ & .04 & $(.05)$ & .11 & $\left(.01^{*}\right)$ & .20 & $(.18)$ & .12 & $(.15)$ \\
\hline Sector & .09 & $(.07)$ & $.01^{*}$ & $\left(.03^{*}\right)$ & .10 & $(.06)$ & $.03^{*}$ & $\left(.01^{*}\right)$ & .06 & $\left(.00^{*}\right)$ & .19 & $(.14)$ \\
\hline Mult. cor. & .321 & $(.248)$ & 305 & (.279) & .266 & $(.292)$ & .322 & $(.267)$ & .334 & $(.339)$ & .391 & (.383) \\
\hline
\end{tabular}

*non-significant, $\mathrm{p}<0.001$

employees who voluntarily or unvoluntarily left the firm showed considerably more absences than those who stayed. Correlations for the Dutch population give a more differentiated picture indicating occupational status may play a more important role.

Secondly, sickness absence severity seems to be predominantly related to type of work (occupational status), consistently showing the highest partial correlations in each national group (each year). The percentage of sickness absence days (as well as the number of spells) is directly related to being employed in manual or staff functions. Further group-specific factors may be noted for the Belgian employees (only: females), and German population (leavers and shift workers), whereas severity rates in Dutch employees are affected by shift work and sector.

Thirdly, the multiple correlation coefficients suggest our combination of variables being somewhat less associated with spell frequency for Dutch employees compared to both other groups, whereas an opposite conclusion may be drawn regarding severity rates. For all groups these selection of factors accounts for a minor part (about 7-15\%) of the variation being explained.

Finally, it is confirmed that several factors taken into the analysis show similar relationships to absence frequencies and severity rates for our groups under study (age, occupational status, length of service). Some other variables showed group-specific high or zero associations (e.g. sex and Belgian severity rates, turnover and spell frequency in the Dutch group).

\subsection{Multivariate analysis of cross-national differences}

So far we considered the association of population characteristics to sickness absence within each national group. But what can - apart from these variables - further be said about cross-group or cross-national differences? This question about "country-bound" sickness absence rates is the subject of our final analysis.

The standardization technique, applied in Chapters 5 and 6 already gave a first answer, indicating increased differences when accounting for three major 
variables. However, some other relevant variables were not included; in particular an eventual firm-related effect stayed out of view. Now for both years of observation an analysis of covariance has been applied integrating six person-related variables, one organizational factor and the macro-indicator "country". Firstly, sickness absence differences have been corrected for the effects of four "co-variates": turnover (stayer, leaver), occupational status, age (numerical) and sex. Co-variates should consist of a dichotomy, or at least be measured on an ordinal level showing a linear association to the dependent variables (severity rates, frequency rates). As age does fulfill this requirement but length of service does not, age has been selected as a co-variate and length of service (in four categories) is treated as a qualitative factor.

After correcting sickness absence differences for co-variates the main effects of each of four independent variables have been assessed (also holding other three independent variables constant).

The results of our analysis for both years and absence measures have been presented in Table 8.7.

Table 8.7 Overview of F-values in analysis of co-variance on three national groups (1980, 1981)

\begin{tabular}{llllcc}
\hline & \multicolumn{2}{l}{ Perc. days per person } & \multicolumn{2}{c}{ Spells per person } \\
\hline Sources of variation & $\begin{array}{l}\text { Degrees of } \\
\text { freedom }\end{array}$ & 1980 & 1981 & 1980 & 1981 \\
& 4 & 291.7 & 266.1 & 112.4 & 137.4 \\
\hline Co-variates-all & 1 & 741.2 & 660.7 & 168.8 & 216.2 \\
- Turnover & 1 & 266.5 & 254.2 & 104.1 & 123.9 \\
- Occ. status & 1 & 154.5 & 100.7 & 89.4 & 87.7 \\
- Age & 1 & 32.2 & 84.9 & 37.5 & 82.0 \\
- Sex & 10 & 30.8 & 21.5 & 28.1 & 46.0 \\
\hline Main-effects-total & 3 & 97.8 & 69.1 & 115.2 & 178.6 \\
- Country & 3 & 13.3 & 14.1 & $1.8^{*}$ & 16.0 \\
- Seniority & 3 & 12.5 & 5.1 & $1.7^{*}$ & $2.2^{*}$ \\
- Sector & 2 & 3.2 & 3.5 & 52.2 & 72.1 \\
- Day-shift work & 2 & 105.3 & 91.3 & 3343.9 & 3240.2 \\
\hline & & 245865.7 & 199266.7 & $(7.1 \%)$ & $(9.7 \%)$ \\
Variance explained & & $(13.4 \%)$ & $(11.9 \%)$ & 46775.4 & 33484.3 \\
& & 1829269.1 & 1667733.4 & 9510 & 9439 \\
Total variance & & 9510 & 9439 & & \\
N & & & & & \\
\hline
\end{tabular}

- non-significant (all other F-values $\mathrm{p}<0.001$ )

The analysis meets however some restrictions. According to Table 8.7 co-variates seem to explain four times as many variance as our main independent variables. However, the effects of both groups of variables is not directly comparable as the effects of co-variates have not been corrected for main effects whereas the effects of the latter have been assessed controlling for covariates. Furthermore, in main variables no interaction could be accounted for due to empty cells in certain combinations (In the German Group the variable "sector" lacks a firm from metal industry). 
Notwithstanding, some highly consistent conclusions can be drawn from this analysis. Among the co-variates "staying or leaving the firm" shows the strongest effects on severity rates, which is already known from previous sections. But after controlling for co-variates and other main variables "country" obviously shows to be the most important factor for observed group differences in severity rates. For frequency rates age shows to be a major covariate. Here also it is clearly demonstrated that "country" is the most important independent factor for diverging in sickness absence frequencies. Finally, vis-à-vis both measures only a minor organization-bound effect ("sector") of selected firms can be observed, which supports the view that our clusters do not contain firms with remarkable organizational sickness absence determinants.

The conclusion may be drawn now that (significant) differences in sickness absence rates between national groups indeed are highly country-bound and cannot be attributed to population characteristics nor to a substantial effect of selected firms. Which elements or characteristics on a system level covered by "country" may account for the striking differences in absence rates goes beyond the scope of this statistical analysis.

The consistency of our findings may finally be demonstrated by applying a "multiple classification analysis" (MCA), being a part of ANOVA. MCA gives a quantification of the effects of co-variates and factors on sickness absence rates. In analogy to the standardization procedure now cross-national sickness absence rates can be presented which make full allowance for all these factors.

Table 8.8 Adjusted sickness absence rates in three national groups $(1980,1981)$

\begin{tabular}{|c|c|c|c|c|c|c|}
\hline & \multicolumn{3}{|c|}{ Perc. days per person } & \multicolumn{3}{|c|}{ Spells per person } \\
\hline & Empir. & Adjusted & Diff. & Empir. & Adjusted & Diff. \\
\hline \multicolumn{7}{|l|}{1980} \\
\hline B & 5.90 & 5.58 & -0.32 & 1.46 & 1.34 & -0.12 \\
\hline G & 8.63 & 7.86 & -0.77 & 1.92 & 1.92 & 0.00 \\
\hline $\mathrm{N}$ & 9.57 & 10.61 & +1.04 & 2.18 & 2.26 & +0.08 \\
\hline \multicolumn{7}{|l|}{1981} \\
\hline B & 5.64 & 5.30 & -0.34 & 1.33 & 1.22 & -0.11 \\
\hline G & 8.62 & 7.86 & -0.70 & 1.87 & 1.86 & -0.01 \\
\hline $\mathrm{N}$ & 8.41 & 9.46 & +1.05 & 2.10 & 2.18 & +0.08 \\
\hline
\end{tabular}

For both years highly identical corrections in absence measures can be observed. The results are quite similar to the outcomes of the standardization, but now seven instead of three relevant variables have been controlled for.

\subsection{Discussion}

Our overview of literature as well as the (multi-) variate analysis showed much agreement on the relationships of population variables to sickness absence indicators. Only two categories of personnel may need further attention, namely female employees and "leavers". 
Female workers in Dutch firms differ in two respects from their colleagues in German and Belgian firms. Firstly, their age distribution is quite deviant from age structure in Dutch males and foreign female employees. About $40 \%$ are younger than 25 years whereas in Belgian and German firms only 19\% and $21 \%$ fall into this age group, respectively. This extremely one-sided distribution indicates Dutch females mainly enter a work force in their early employment years and high proportions terminate after some years.(5) Secondly, the agespecific severity rates indicate $40 \%$ higher sickness absence percentages in Dutch females aged 25-35 years. This pattern, also depicted in other statistics is probably attributable to confinement periods and exceeded absence rates before and after delivery. So this may illustrate the higher fertility rates in Dutch females, but also more health problems in coping with the combined work and housekeeping pressures may account for this effect. The combination of both findings demonstrates that in Dutch firms female workers are more mobile and only temporarily participating in the labour market.

The role of withdrawal, selection processes and work force composition is also emphasized by the association we found of "turnover" to sickness absence rates. Both in the Belgian and German group "leavers" and those "aged under 25 years" are markedly high risk groups regarding their number of sickness absences. Our analysis indicates persons leaving Belgian or German firms may do so in connection with having shown many absences whereas in Dutch firms reporting sick frequently seems to deviate less seriously from average frequency patterns (cf. Section 6.2.2). Those entering employment will have to accommodate to firm norms more strictly than in Dutch firms. In Dutch firms high frequencies are a more wide-spread phenomenon and can not be attributed to particular categories of personnel. Leavers from Dutch firms are predominantly characterized by many absence days lost. As job protection regulations prevent dismissal of sick persons this finding suggests a major role of transfer to disablement pension as leaving ground. Finally the analysis threw some more light on the relative importance of personal and job-related population characteristics vis-à-vis cross-national sickness absence differences. Controlling for some major personal factors, work-related variables and a company effect the heterogenous variable "country" is shown to be the major factor explaining sickness absence differences.

\subsection{Summary}

Comparing cross-national figures to identify determinants of observed differences may take several steps, depending on the level of observation. In this chapter the first step was made: personal factors and work-related variables were examined regarding their relationships to within-group absence rates and associations with observed between-group absence differences. Generally speaking, findings from local investigations and from our analysis showed a high agreement on associations and risk groups. Individual factors known to affect sickness absence obviously do not stop at one side of the national border.

However, conditions under which they affect absence rates may limit or facilitate their effects. In particular, turnover or "leaving the firm" showed high 
correlations with spell frequency in the Belgium and German personnel. This finding suggests these firms apply selection processes which take absences into account. In Dutch firms, however, leavers were not characterized by many absences but by many days lost.

The main facilitating or restrictive condition, however, seems to be "country". This heterogeneous term, covering a cluster of yet unspecified socio-cultural, social security, job security or health care elements, showed to be the most important independent variable vis-à-vis sickness absence differences. Now that most personal variables have been "ruled out" as explanation for our findings, we will have to focus our attention on factors or conditions of the next level of analysis: the firm. 


\section{NOTES}

(1) Under the condition that the sum of the categories (weighted by the number of objects covered) adds up to zero. Actually, the first step is accomplished by treating every separate category as a dichotomous 'zero-one variable' to maximize the correlation between the canonical variates of the two sets.

(2) Under the restriction of a linear or at least ordinal transformation of the categories of the dependend variable, this part of CANALS is identical to stepwise multiple regression analysis as it can be separately applied to the rescaled variables.

(3) Comparable to regression-weights in multiple regression.

(4) This is also the reason that only ordinal or linear transformation are allowed for the dependent variable, because otherwise an interpretation of the results can only serve an explorative value.

(5) OECD and EC sources confirm our findings on low labour force participation rates of females aged over 35 years. 


\title{
CROSS-ORGANIZATIONAL COMPARISON OF SICKNESS ABSENCE POLICIES
}

\begin{abstract}
9.1 Introduction
Organization-bound factors, operating on the mesoscopic level of firms may account for considerable differences in sickness absence. Therefore, the next step in our explanation aims at the detection of organizational aspects that might affect the absence rates observed. From the multivariate analysis in Chapter 9 we already know firm ("sector") shows a minor effect on crossnational differences. To throw some light on this finding, a more substantial analysis of company-related aspects is needed. We already noted considerable differences between countries in the employers financial involvement (continuation of wage payment) and his rights regarding legitimation and surveillance procedures (cf. chapter 3). Furthermore, the legal regulations and company procedures regarding dismissal during or due to sickness absence need some clarification, as the application of disciplinary measures is a constant feature in discussions on the subject. So the cross-organizational comparisons within each cluster may provide an important insight in company policies within various social security contexts.
\end{abstract}

Research conditions, however, considerably determined the scope and contents of this part of our comparisons. From the onset it was clear that an ideal of surveying (matched) samples of employees and staff from cluster firms would be unattainable. Within given limitations no attention could be paid to main determinants of sickness absence in our firms as health conditions, work stress and strains or work related attitudes in the work forces. In only the most favorable conditions a few informants might be available for an interview, which would highly restrict the number and validity of issues to be compared across firms. So it was decided to make a merely qualitative comparison based on a few comparable informants per firm. The aim was to examine whether similar firms as to their product and technology (size and location), operating within various macro-social settings, consistently showed differences in policy and practices regarding employment and work incapacity.

To that end four key informants with an expectedly high probability of cooperation were proposed to be interviewed, namely

- the (assistent) personnel manager, usually being charged with social security and sickness absence matters;

- the occupational physician, having a more or less extended job regarding safety and health problems in the organization;

- a head of a production department, representing managements attitude and role towards sickness absence;

- a representative of the workers council, to "measure" the opinions and experiences of the work force vis-à-vis personnel policy, sickness absence, strategies applied, safety and health issues. 
We realize this selection of "experts" in our subject can not validly reflect the opinions, actions and policies within each firm (although for the Netherlands Nijhuis' investigation (1984b) showed a considerable consencus between personnel managers and workers representatives in evaluating working conditions. But within the research conditions given they were expected to provide a minimum basis for a comparison of organizational aspects vis-à-vis sickness absence.

\subsection{Organizational aspects selected}

As indicated in Chapter 7 in particular in the Netherlands several investigations have been made on the association of company-bound characterictics to sickness absence. Several of these organizational factors are conditioned by the wider (legal) context of employment and social security regulations. In this way our study should not only allow comparison of actual resemblances on firm level, but also contribute to a proper view on procedures and arrangements in these areas.

The selection of organizational characteristics to be compared comprises three main categories, each consisting of various items:

\section{Personnel policy:}

- size and tasks of personnel department;

- employment policy (e.g. regarding the impact of fluctuations in the production);

- working hours, yearly number of working days;

- attendance rules and registration.

The first aspect covers the size and contents of personnel management, which may affect priorities and ways of dealing with sickness absence and other social security or employment issues. Secondly, company personnel policies are considered, not only regarding the employment problems (e.g. lay offs, partial unemployment, temporary labour contracts); also stringency of reporting and control procedures as well as disciplinary action taken (tardiness) may throw some light on firm strategies.

\section{Working conditions and occupational bealth care:}

- size and tasks of occupational health department;

- procedures regarding work incapacity due to industrial accidents;

- working conditions in selected production departments;

- role of company physician regarding work incapacity.

Our second category of items indicates the scope and organization of preventive actions regarding hazardous or unfavourable working conditions. But also the occupational physicians role vis-à-vis sickness absence, and reintegration of disabled will be compared as the profession does not completely comprise the same tasks and responsabilities across nations.

\section{Sickness absence policy and the operation of social security arrangements:}

- certification and reporting procedures;

- medical supervision and control;

- organizational relevance and available data; 
- perceived causes of sickness absence in firm;

- measures and procedures applied towards frequently sick, long term sick and departments with high absence rates;

- job adaptation and transfer to invalidity pension.

The main part of our organizational comparison considers several elements of firm policies towards sickness absence. Reporting procedures, control strategies or employee counselling, as well as their perceived results will be examined and compared. It was expected within given research conditions this selection of themes might contribute to a minimal insight in company strategies towards sickness absence and other employment aspects.

\subsection{The collection of data}

The extended Dutch tradition of sickness absence research provided the elements for a questionnaire which has been constructed in four versions for our informants. (1) The Dutch-Belgian versions have been tested in two comparable firms in Belgium and the Netherlands. The German versions have been constructed in cooperation with two experts on the subject matter (personnel management assistant, social researcher) and some were subsequently tested in a German firm. These pre-tests and the consultation of local researchers showed a need for improvements vis-à-vis construct validity, linguistic equivalence and length. But in particular a valid understanding of the social context and meaning of certain aspects needed serious attention in our study. E.g. within prevailing labour relations "visiting sick employees" may be regarded as a silent control ("sick spy"), whereas in other settings this action of colleagues or supervisor is considered as appreciated "social involvement". So it was intended not only to compare actions but also to attempt to understand them in the local social context.

Notwithstanding, it became clear that cross-cultural differences in openness and the risks of socially desirable answers could not fully be excluded from our investigation. In particular personnel managers from our German firms showed many hesitations. This attitude may not only stem from the management point of view considering absence as a negative productivity indicator. Also the fear was expressed the interview with a workers council representative might evoke internal unrest (see also for similar experiences: Dennerlein \& Schneider, 1985). But in some Belgian and Dutch firms the desired combination of informants also could not be realised. In the end the interviewing was faced with several restrictions:

- only two Belgian and one Dutch firms allowed interviews with all four informants proposed;

- in all German firms only the personnel manager and the company occupational physician could be interviewed;

- interviews with production managers and a workers council representative were held in just five and four firms, respectively. But in two Dutch firms also the "social worker" employed by the company has been interviewed.

In most Belgian and Dutch firms the requested visit of the production departments has been made between interviewing. This incomplete cooperation and consequently the dissimilarity of sources seriously limited the validity of the cross-company comparison. Therefore, it was decided to base our comparisons 
primarily on the information obtained from those informants interviewed in all firms: the head or assistant from the personnel department and the occupational physician. (2)

Some questions and items were excluded from analysis when shown to be unreliable or not fully answered (due to lack of time). Consequently, some themes related to the priorities and size of the personnel department, occupational health care provisions or working conditions became underrated. Finally, to improve the validity of our findings all key informants had the opportunity to review the draft case study reports based on the interviews and firm documentation received. Notwithstanding, the common basis of our comparisons remains rather small, namely information only obtained from cooperative personnel managers and occupational physicians.

\subsection{Personnel policy and occupational health service}

For efficiency purposes we will not compare and report organizational characteristics for each cluster seperately, but our findings will be included directly in an over-all comparison.

\subsubsection{Personnel policy}

Some Dutch studies in particular made clear that the quality (professionalization) and size of the personnel department does affect the kind of absence policies applied. Due to differences in the organization of personnel management functions (e.g. internal or external wage and personnel administration) the relative size of personnel departments was not directly comparable. Taking this into account however, some differences could be observed. In Dutch firms personnel departments seem to be rather larger: 0.7-1.7 personnel manager per 100 employees was employed wereas these rates were smaller in both other groups (0.4-0.7 for Belgian firms, 0.5-0.7 in German firms).

Time spent on personnel management issues showed many similarities across firms, e.g. as to personnel planning and recruitment, training, social security, working conditions. Only on three aspects were some differences noted. In Belgian firms "personnel administration" takes a prominent position and contacts with workers council and managing director seem to have a lower priority, compared to personnel departments in German and Dutch firms. Furthermore, Dutch personnel management indicated that they spend considerably more time on "social counselling" of individual employees (e.g. employees with private or work related problems) than their Belgian and German colleagues.

Also the ways firms solve personnel planning problems were highly comparable. Acute problems in production units rising from high absence frequencies are generally solved by a temporary transfer of employees between departments. In some German firms a special well trained group of workers is available to fill in gaps. In periods with production peaks all firms apply overtime working, internal transfers or employment on temporary contracts. When production has to be lowered the range of measures covers termination of temporary employment, and in serious instances, collective working time reduction (in German or Dutch firms). In some Belgian firms temporary un- 
employment for groups of production workers had been applied, in general only lasting a few weeks. Belgian legislation provides less restrictions to such collective measures (only agreement of workers council is required), compared to the German and Dutch situation where the permission of a governmental "labour inspectorate" is required (Yemin, 1982).

During our observation period (1980-1981) the normal weekly number of working bours was 40 in German and Dutch firms but 38.5 hours for Belgian employees.(3) On the yearly number of days off, German firms showed a deviant pattern. Disregarding seniority based extra days, or "compensation days" for shift workers, in general some remarkable differences were found. (cf. Table 9.1)

Table 9.1 Average annual number of days off in three national groups $(1980,1981)$

\begin{tabular}{lcclccc}
\hline Nat. Group & \multicolumn{2}{c}{ Public Holidays } & \multicolumn{2}{c}{ Annual leave } & \multicolumn{2}{c}{ Total } \\
\cline { 2 - 6 } & 1980 & 1981 & 1980 & 1981 & 1980 & 1981 \\
\hline B & 10 & 10 & 20 & 20 & 30 & 30 \\
G & 11 & 10 & 25 & 25 & 36 & 35 \\
N & 8 & 6 & 23 & 23 & 31 & 29 \\
\hline
\end{tabular}

German and Belgian workers have most days off for public holidays, whereas Dutch workers have less days off due to religious or national events. In contrast for Belgian employees annual leave is just four weeks, whereas German and Dutch firms provide on average five or three days more, respectively.(4) In the end Table 9.1 indicates that the groups with the lowest or highest sickness absence rates have a fairly identical number of days off in a year. So it may be concluded that the hypothesis that the restricted number of days off for Dutch employees account for their higher absences can not be confirmed here (Vroege, 1982).

Furthermore, regarding the daily organization of working time, no clear crossnational differences could be observed. Except in the German firm all firms operate a time registration which sometimes is only applied for manual workers or employees with variable working times. The consultation of a doctor (general practitioner, specialist) during working time is allowed with continuation of full wage payment in German and Dutch firms. But in three Belgian firms it depends on the employers decision whether wage is paid for this category of absences. In all firms more or less frequently the same disciplinary measures are said to be applied towards tardiness, ranging from oral and written warnings to wage cut or dismissal. No systematic differences were found on the application of these measures, with one exception: in three Belgian firms attending work a few minutes too late automatically implied a fixed loss (15 minutes) of time paid.

\subsubsection{Occupational health care and working conditions}

Taking the restrictions of our information into account our study gave a very heterogenous picture both within clusters and within national groups. Firstly, 
one essential difference is the occupational physicians role in evaluating work incapacity. In three Dutch firms the occupational physician also made medical examinations for sickness benefits arrangements which, of course, affects the pattern of the tasks in the occupational health service. From other sources it is known that about $50 \%$ of Dutch occupational physicians also evaluate work incapacity (De Winter \& Dijkstra, 1984). Belgian and German occupational physicians are not allowed and do not wish to evaluate work incapacity.

Secondly, a comparison of the ratio of occupational physician hours to work force size indicated the lowest level of available time being found in German firms. But including the working time of the occupational nurse no systematic difference were found anymore between national groups. With an exclusion of their "social security tasks" however, Dutch company physicians showed to spend comparatively least time to "their" personnel. Finally, regarding the priorities in time allocation by the physicians many further similarities were found, with the exception of time spent for consultations and counselling. This part of the job seems to take a more prominent part in the activities of Dutch physicians, whereas German and Belgian physicians seem to spend more time on regular health checks in certain risk groups (e.g. working under cold or very noisy conditions).

Furthermore no systematic differences were found in the reported reputation of the firms (regarding working conditions), perceived safety level (incidence of industrial accidents) or the provision, supervision and use of protective clothing and equipment. Differences tended to be more apparent between than within clusters. In general most informants were satisfied with the use of protective clothing, whereas also common problems could be observed nowadays (e.g. safety shoes for female employees). No firm gives rewards for periods of accident-free working, though three Belgian firms applied this "tool" in earlier years.

Procedures and actions taken in case of (serious) labour accidents, showed to be highly comparable across firms. Accident investigation on-the-spot, inspection by a governmental agency ("labor inspectorate"), and attempts to create a flexible work resumption (on a part time or adjusted job) were reported actions taken in each firm. In all groups it often was suggested the employer being more willing to adapt jobs for injured workers than in the case of "genuine" long term sick employees.

\subsection{Sickness absence policies and the social security context}

The core of our inquiries comprised several organizational aspects of sickness absence and related problems, e.g. transfer to invalidity pensions. To gain a better insight in the operation of social security procedures and arrangements was intended as an important sub-goal.

\subsubsection{Sickness absence: an organizational priority?}

High levels of sickness absence affect manpower planning and personnel costs, but also indicate organizational problems or bad health conditions in groups of employees. Our informants perceptions of the relative sickness 
absence level in their firm (vis-à-vis comparable firms or sector) were very similar within clusters. (5) The perceived rank, however, does not seem to affect the evaluation of sickness absence being an organizational problem. In Dutch firms three of four personnel managers indicated sickness absence is an important problem area whereas the same proportion of their Belgian colleagues signify a low priority. Furthermore, no consistent differences were found vis-à-vis the awareness of financial consequences of sickness absence, or the utilization of absence figures from management information systems.

\subsubsection{Certification and sick reporting}

In our firms reporting sick generally occurs in similar ways. Before or within a few hours after work begin, the employee has to report sick with the personnel department, his supervisor or the firm porter. In the majority Dutch employees inform the porter or telephonist whereas most Belgian workers have to contact higher authorities, their supervisor or the personnel office. In German firms no clear preferences were observed.

Within 1-3 days Belgian and German employees have to send the employer (and sick fund) a medical certificate stating unfitness for work and its prognosed duration. In three Belgian firms all spells have to be medically certified; in one firm one-day-spells are excluded from this rule. German regulations prescribed a certificate for spells lasting over three days. Certification from the first day on may be required for "frequently sick" or those engaged shorter than a few (5) years. In both groups of firms omitting certification usually results in wage loss. Furthermore, it should be noted that for Belgian workers the cost of consulting the physician are not fully compensated by the sick funds.

Opinions on the adequacy of legitimation procedures could easily be evoked, generally indicating that this subject has some controversial aspects. All personnel managers interviewed and most occupational physicians advocated compulsory authorization for effective claim supervision. It is expected that employees would take more absences when legitimation at the onset of work incapacity is lacking. Though in both countries empirical evidence on this subject is lacking, it was further stressed that employees accept and support the necessity to certify work incapacity. Providing medical evidence is often also required in other areas, e.g. school absence. ${ }^{(6)}$

Criticism was mainly expressed by our informants vis-à-vis the provider of the certificate: usually the family doctor, who is thought to be unfamiliar with the job content or working conditions of his patients. Therefore he would advise cessation of work too easily and for too long a period when a patient seeks advice or treatment. Particularly in these countries with a high density of general practitioners the rivalry between family doctors or their economic dependency on their patients would encourage a compliant attitude. Belgian and German respondents were highly congruent regarding their experiences or opinions towards certification of work incapacity.

\subsubsection{Supervision of work incapacity}

Also the way work incapacity is controlled by sick fund or on behalf of the employer, diverges considerably between Dutch firms and their German or 
Belgian counterparts. In all firms located in the Netherlands lay sick inspectors, employed by the occupational health service or the industrial association, visit the sick on the first till third day of work incapacity. For three firms the medical inspection is performed by the occupational physician, but after 10 weeks of work incapacity two of them transfer this task to social security doctors employed by the funds.

Supervision of sick employees from Belgian firms is usually performed by medical officers of sick funds. According to our sources medical checks of (continuing) work incapacity usually start after a few weeks, namely when benefits become payable. All Belgian personnel managers reported to make use of extra medical examinations by general practitioners, be it on an occasional or regular basis. They are working on behalf of the employer, to control unfounded absences. German employees may be medically examined by social security doctors employed by an independent body ("Vertrauensärztliche Dienst") acting on request of the sick fund. Only incidentally our German firms asked the funds to have a medical check of work incapacity performed.

Medical monitoring issues raised twice as many negative as positive evaluations. There were no consistent differences between clusters, national groups or professions. Negative opinions were expressed regarding bureaucratic procedures and the fund doctors lack of knowledge on working conditions. As positive aspects the psychological effects of supervison on sick employees and their working colleagues were mentioned.

\subsubsection{Opinions on major sickness absence causes}

In the interviews personnel managers and occupational physician were asked to indicate on a list of sickness absence causes which factors they regarded most relevant in their firm. Accounting for the number of factors mentioned only a few patterns could be discerned in the opinions expressed. Opinions on aspects of work (working conditions, shift work, etc.) did not appear to be cluster-bound. Those few differences observed were merely cross-national and only partly related to the informants profession. Belgian and Dutch informants firstly ascribed company sickness absence to the effects of "working conditions" (e.g. physical and mental stress, leadership style, stability of working groups). Next Belgian informants mentioned "socio-cultural factors", e.g. employees work attitudes, risk taking behavior (e.g. excessive drinking, or sport accidents). Dutch informants rated on second place "social security factors" like benefit level, legitimation procedures, supervision policies. Both professionals from German firms perceived "socio-cultural factors" as the major background of sickness absence in their firms, and "working conditions" as a secondary factor.

In all national groups two other categories of factors received relatively low scores, namely "work force composition" (as to aged employees, working mothers, migrant workers) and "firm sickness absence policy" (e.g. disciplinary measures, or job adaptation for long-term sick). Comparing the evaluation of these five categories of sickness absence factors highest concensus could be observed in Dutch respondents whereas Belgian personnel managers and occupational physicians showed most discrepancies. On some other aspects of 
sickness absence no differences were observed. "Hidden sickness absence" (Krankheitsverschleppung", "Ziek doorwerken") in persons with a bad health condition refusing to report sick, generally is said to be rare, and the same is thought about "pseudo-sickness absence". However, Dutch informants seem to consider the latter type of absences as a greater problem than their foreign colleagues.

Finally, respondents opinions on backgrounds of cross-national differences on sickness absence were compared. Over $80 \%$ of all factors mentioned by our Dutch informants fall in the province of sickness benefits regulations. Their Belgian colleagues gave a less mono-causal interpretation: both the differences in income maintenance programmes and socio-cultural fators (e.g. employees attitudes towards work and health, organizational commitment) w're expected to account for supposed differences. German informants demonstrated a position between these viewpoints; social security aspects score highly but also considerable weight is attached to socio-cultural and work related factors (working conditions, organizational climate, leadership styles, disciplinary measures).

\subsubsection{Comparison of sickness absence policies}

One of the main issues in our organizational comparison was the policy applied regarding sickness absence. To create maximal comparability respondents were asked to describe measures generally taken regarding three types of sickness absence "problems":

a. an employee being frequently absent due to sickness, for only a few days per spell;

b. an employee already being work incapacitated for over three months;

c. a firm department with recently increasing sickness absence rates;

In almost all firms employees being frequently sick for one or a few days are invited for an interview with their supervisor or personnel manager. This may firstly have an informative character, but next an oral or written warning and threat of dismissal are expressed. Neither the warning nor the (reported) realization of dismissals seem to be cluster- or country-bound. Interviews do not indicate that in Belgian firms the legal opportunities for dimissal during or due to sickness absence are more frequently used than in Dutch firms with more formal obstacles for applying such a measure.

Further actions toward frequently sick do show only a few country-specific patterns. In Dutch firms a "quick second medical examination" may be requested as well as a (temporary) job change (e.g. transfer to other shift, flexible working time). These actions seem to be lacking in the Belgian and German repertoire, which probably are more oriented towards disciplinary actions.(7) In general the effects of the measures applied are said to be uncertain and arbitrary. In several firms our informants showed opposite opinions on the effectiveness of the most widespread action (interview).

Company policies towards long term sick employees seem to show more variety. Home visits are rather usual in Belgian and Dutch firms but this activity seems to be rare within German labour relations. Temporal adaptation of 
jobs (e.g. regarding working time, and work place conditions) are said to be attempted in all Dutch firms, but were less reported for the other organizations. All German company doctors said to contact the employees therapist about work capacity prospects, and two firms financially supported employees participation in alcohol addiction programmes, or other rehabilitation measures ("Kur, Heilverfahren"). Finally, in the majority of Belgian and German firms as a rule resumption of work is followed by an interview with the personnel official (German firms) or occupational physician (in Belgian firms). This way German managers intend to stress employee indispensability and stimulate organizational commitment, whereas the Belgian occupational physician wants to check whether the employee can fully perform his former job. But one action seems to be rare and has been reported for only one firm in each group: the dismissal of long-term sick.

Rising sickness absence rates in departments or sections of a firm may indicate growing socio-psychological or health-related problems in personnel. Our informants were asked which measures are taken vis-à-vis such indicators manifesting on a group or organizational level. It may be concluded that in almost all firms sickness absence is rarely approached at this "policy level". In most firms nothing (special) is done, except the personnel manager talking with the supervisor.

\subsubsection{After exhaustion of sickness benefits....}

Firms were also compared regarding their policy towards long term work incapacitated employees and prospects for further employment. The lack of information and reactions coloured by their social desirability only allow a rudimentary conclusion, however. In general employers seem to support employees claims for disability benefits. They may incidentally differ vis-à-vis additional efforts to employ workers who did not qualify for this transfer. E.g. one Belgian and one German firm reported attempts to find a suitable job for a worker whose invalidity pension claim had not been rewarded. In general it is suggested that employees who did not satisfy eligibility criteria are faced with unemployment if work is not resumed. In Dutch firms the occupational physician or personnel manager will contact the occupational association to discuss future prospects for long term sick, knowing that after 52 weeks of work incapacity most claims for an invalidity pension will be accepted. In some of these firms the employee is counselled to prepare him to his new work-less existence.

All firms reported to employ some (partly) disabled person, but no crossnational differences could be observed regarding compliance of quota arrangements. In Germany, with the most extensive employment quota for disabled persons, one firm reported $8 \%$ of jobs were occupied by disabled. Informants from another organization indicated rationalization and lack of suitable jobs made compulsory payment of a fixed sum per required job more attractive.

Finally, "waiting periods" in health care as a source of prolonged work incapacity, were only reported by some Dutch informants. Most Belgian personnel managers and company doctors rejected this factor, as a large supply of specialists and hospital beds would provide immediate access to specialized treatment in this country. 


\subsection{Employee turnover and sickness absence}

The final part of our cross-organizational comparisons considers more extensively some aspect of personnel selection and turnover. Several sources (cf. Porter \& Steers, 1973; Kruidenier, 1984) and our own analysis (cf. Section 8.4.2) indicated persons withdrawing from a firm usually show higher sickness absence rates than those who continue attendance. Now we will examine whether sickness absence patterns of "leavers" are similar in each group, which also might give some insight in the role of dismissals.

Firstly, it may be noted for our entire observation period turnover rates did not show significant differences between national groups. Of all persons employed yearly about $11-12 \%$ terminated their contract.

Figure 9.1 Average yearly severity and frequency rates in entrants, stayers and leavers (1980 and 1981)
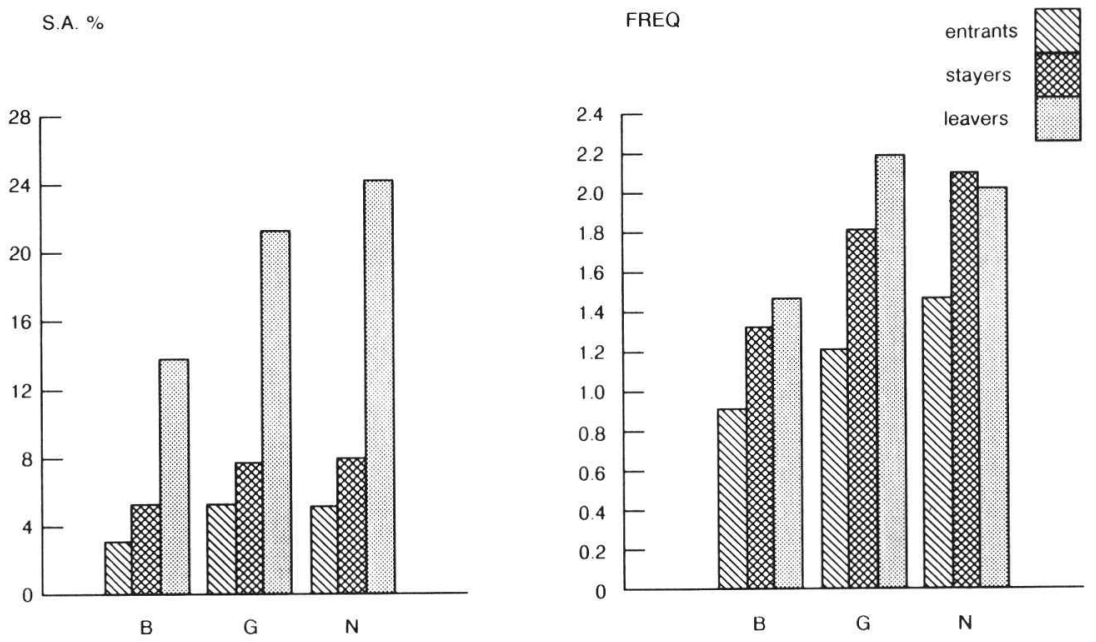

In all groups persons entering the firm showed rates about $30-40 \%$ under average level (cf. Figure 9.1). Those who left the firm demonstrated considerably high severity rates (B: $13.8 \%$; G: $21.3 \%$ and $\mathrm{N}: 24.3 \%$ ). Related to the group mean however, differences become quite similar: leavers exceed average severity rates by about $250 \%$. For frequency rates a slightly different conclusion may be drawn: whereas in the Belgian and German group leavers show about $10-20 \%$ more spells respectively, in the Dutch group even less absences $(-2 \%)$ may be noted. As we already saw in Dutch personnel leavers are characterized by their high number of days lost, whereas in other groups former employees also show a higher spell frequency.

A further insight in withdrawal and sickness absence is restricted by incomplete information from Belgian firms on the reason of leaving. Therefore our comparison will be restricted to the German and Dutch group (cf. Table 9.2). 
Table 9.2 Sickness absence rates in leavers in two national groups (1980 and 1981)

\begin{tabular}{lrrrr|rrrr}
\hline \multicolumn{7}{c}{ German } & \multicolumn{3}{l}{ Dutch } \\
\hline & $\mathrm{N}$ & $\%$ & sa \% & freq. & $\mathrm{N}$ & $\%$ & sa \% & freq. \\
\hline Disablement pension & 26 & 2.7 & 51.1 & .79 & 136 & 16.0 & 74.2 & 1.39 \\
Voluntary departure & 345 & 36.2 & 14.7 & 2.07 & 397 & 46.6 & 11.9 & 2.45 \\
Dismissal & 190 & 20.0 & 19.0 & 2.60 & 128 & 15.0 & 23.7 & 2.69 \\
Old-age pension & 175 & 18.4 & 22.9 & 1.75 & 83 & 9.7 & 11.3 & 1.21 \\
Death & 38 & 4.0 & 27.1 & 1.74 & 17 & 2.0 & 39.1 & 2.38 \\
Other & 178 & 18.7 & 17.1 & 3.20 & 91 & 10.7 & 4.5 & 1.38 \\
\hline Total & 952 & $100 \%$ & 21.3 & 2.19 & 852 & $100 \%$ & 24.3 & 2.02 \\
\hline
\end{tabular}

Though the validity of the distinction may be weak, "voluntary departure" (employees initiative) and "dismissal" (employers initiative) seem to be the most frequently reported leaving grounds. Furthermore, in the German group "old-age pension" and "death" are more frequent employment termination reasons than among Dutch employees (which may only partly be attributed to their age structure). But in the Dutch group transfer to disablement pension is a very prominent reason for leaving. A closer inspection shows its average incidence rate (frequency per 1000 employees) is 17.8 whereas in the German group only 3.4 per 1000 may be noted.

Table 9.2 further suggests in dismissing employees the employers in both groups may consider poor health and attendance records. Persons being fired are showing more absences and higher days lost percentages than those leaving on their own initiative. No clear cross-national differences can be observed, however.

\subsection{Discussion}

Regarding employment policies, occupational health care and sickness absence strategies our conclusions should be looked at with some reservation. Two informants provided most information for each firm, both being expert, but also connected to our subject, which may seriously bias our interpretation ("social desirability"). There was hardly any opportunity for external validation, although in those firms where a supervisor or workers representative has been interviewed, a considerable degree of concensus could' be noted with responses of personnel manager and occupational physician. Further, our insight could be enriched by some findings from earlier studies on our subject. The personnel management function in our firms showed many resemblances. Most noteworthy differences concern the relative size of this department and alleged priorities in personnel policy. Dutch firms seem to be more extensively staffed, with qualitatively more expertise on social policy. Whereas Belgian and German firms may be typified by a mainly economically and judicially orientated approach to manpower issues, in comparable Dutch firms more time and expertise may be spend on social issues, such as employee counselling (two larger firms employ a social worker in their personnel department). Some German informants suggested both the avanced professionalization of personnel management in the Netherlands as well as the centralization in decision-making in German companies may account for these differences in weighting social policy (cf. Child \& Kieser, 1979). 
Employment strategies applied showed many similarities across firms. One striking difference, however, could be noted. In the case of temporary work force reduction due to economic reasons the Belgian employer is faced with less legal requirements or authorization than his German or Dutch colleague. After informing the works council the employer may suspend his manual workers' contracts completely (for periods lasting four weeks maximally) or introduce short time working for a certain period. In three of our Belgian firms such measures had been taken in our observation period, whereas in the German and Dutch group one firm introduced temporary work time reduction. In Germany and the Netherlands the employer has to make an application to a public authority (federal labour office, labour inspection). Further, several conditions (specified causes and labour market condition) have to be satisfied to have working time reduced (Grais, 1983; Yemin, 1982). These differences indicate the employment of workers is being more protected under German and Dutch regulations than in the Belgian situation. Also disciplinary strategies regarding tardiness (fixed loss of earnings) reflected more stringent, employeroriented employment conditions in Belgian firms.

Occupational bealth care is provided in all firms under study. Nation-wide, however, large differences do exist regarding the degree of development of occupational health care. For all employees in Belgian firms but in the Netherlands only for those employed in firms with over 500 employees occupational health care is obligatory. Consequently only about $40 \%$ of Dutch workers are covered by occupational health care (Buijs, 1985). Daily tasks and activities of company doctors seem to overlap considerably, with the exception of evaluation of work incapacity, which was only performed by Dutch occupational physicians. "Subtracting" this task from daily activities of Dutch plant physicians it came out both in Belgian and German firms in average more occupational health care hours are spent per 100 employees than in Dutch firms. This may be attributed to historical and legal backgrounds: particularly in Belgian legislation for many categories of persons at risk a regular medical investigation is prescribed (Diller \& Fegers, 1979; Gevers, 1983). Also in German firms occupational health care is more widely spread than in the Netherlands. Not only its restricted coverage but also tasks performed make the Dutch situation remarkable. Finally the personnel manager, but also the Dutch physician seems to spend more time on employee counselling or consultations ("overleg") with employer, socio-medical teams etc. than their foreign colleagues.

Belgian literature on company policies towards sickness absence is rare, and also German sources provide just limited information to guide our interpretation. Trebesch states financial incentive systems as well as disciplinary strategies are predominant in German firms. Much attention is being paid to the jurisdiction on dismissals due to or during (sickness) absence (Trebesch, 1979). In Dutch firms both person-oriented as well as structural approaches (work- or company-bound factors) may be found, but also the operation of benefits arrangements gain growing attention (e.g. Verbaan, 1986).

Only Belgian informants indicated sickness absence is not a topic in their firm personnel policy, which is not very surprising vis-à-vis the levels observed. 
Also in Belgian firms employers control strategies are most varied and sick reporting procedures applied seem to be less flexible compared to German and, particularly, Dutch firms. Generally all spells have to be medically certified whereas in many German firms spells lasting 1-3 days are excluded from this obligation. Finally, in this country company control methods may also comprise "second opinion" of an employees work incapacity, made by a physician on behalf of the employer.

Dismissals due to frequent absenteeism meets most restrictions in Dutch labour legislation. However, personnel managers from each national group indicated this measure is being used, be it sporadic. The multi-variate analysis (cf. Table 8.4) showed "leavers" to be a high frequency risk group in Belgian and German employees, a category which certainly will contain lay offs. Trebesch (1979) observated: as "dismissal due to absenteeism" still receives regular attention in German personnel management- or judicial journals, its application is quite probable or will at least be seriously considered. In their representative survey Falke et. al. (1981) found $20 \%$ of dismissals were formally and solely based on long-term or frequent sickness absence, but this rate was considered underestimating reality.

Some actions vis-à-vis sickness absence seem to be country-bound. Under German employment relations home visits to seriously ill employees may be seen as offending privacy. Belgian and Dutch workers seem to lack early preventive and rehabilitative measures as provided by the German sickness and invalidity arrangements (e.g. "Kur"). Moreover, as medical authorization of work incapacity is lacking at the onset of work incapacity Dutch employees are much more confronted with medical and semi-medical supervision than those employed in Belgian and German firms. It should be considered, however, that German and Belgian procedures differ on an essential aspect from the Dutch situation. In the latter a medical expert checks the work incapacity and health-related behavior of the employee, whereas in Belgian and German procedures a social security doctor reexamines the decision of his colleague (usually the employees family doctor). The Dutch supervisory doctor may prescribe resumption of work; his Belgian counterpart may, if his medical examination leads to a different opinion, only advise to return to work, which has to be legitimated again by the general practitioner. Supervision may now easily create conflict between two medical professionals, which may be stimulated by the need for both doctors to state their point of view.

Finally, the Dutch situation is essentially characterized by a comparatively major role of transfers to disablement pensions. Probably more light may be thrown on this phenomenon in the comparison of national income maintenance provisions.

\subsection{Summary}

In preparing our cross-organizational comparison it became clear that research conditions were not similar for all firms that earlier had provided sickness absence data. Many (in particular German) firms refused to have a selected number of respondents interviewed on working conditions, personnel policy or social security issues. In the end only information on a selected range of 
subjects could be used, obtained in interviews with personnel managers and occupational physicians. Taking account of their limited validity (social desirability risk) still some similarities and disparities can be shown that may contribute to our understanding of sickness absence differences observed. Both in their activities and available expertise in Dutch personnel management a less economic and judicially oriented approach was noted towards employment and sickness absence compared with Belgian and, especially, German firms. Further in Dutch firms occupational physicians and nurses on average showed to spend less time (per 100 employees) than both their colleagues in similar foreign firms. Especially their role vis-à-vis the assesment of work incapacity is extraordinary, as Belgian and German occupational physicians legally are not allowed nor willing to evaluate absences. Dutch plant physicians however, show to spend considerable time on the supervision of sickness benefits claims and employee counselling.

The relatively non-disciplinary orientated approach by Dutch personnel management and plant physicians may strongly be related to the larger supply of long term sick and four times higher incidence of persons terminating work due to disablement. In both other national groups "leavers" also showed to be a high risk category, but here they are characterized by many absences. Our inquiry provided some clues that in Belgian and German firms "dismissal" may be used more often compared to Dutch employers. Finally, the range of disciplinary measures to be applied (legally) seems to be widest in Belgian firms and most restricted in Dutch companies. 


\section{NOTES}

(1) The questionnaires were semi-structured; for some questions cards were handed to the respondent containing question and answer categories.

(2) Remaining 13 interviews held with some production managers, labor union representatives, social workers or two company were only used to clarify factual information, if necessary.

(3) In most firms shift workers had the same or 1-3 hours less to work as day workers, whereas in a German firm shift work lasted one hour more.

(4) Recent OECD overviews indicates that Dutch employed nowadays have most days off annually due to working time reduction arrangements. (cf. Chapter 11).

(5) Personnel managers from firms in the Paint or Metal Cluster indicated an average level of severity rates; for all Margarine firms rates were thought to be lower than average in the sector, whereas all Frozen food firms were known to show relatively higher rates, compared to overall branch figures. These indications match with information provided during the selection of firms for the quantitative part of our investigation.

(6) This opinion seems not te be limited to staff and managerial informants: also for labour union representatives interviewed the need for certification was self-evident.

(7) Belgian firms further showed a great interest in "legitimation patterns" of general practitioners (by "analyzing" obtained certificates) and occasionally local family doctors were invited to a collective company visit. 


\section{SOCIETAL Determinants OF SICKNESS ABSENCE}

\subsection{Demarcating the problem}

Our analytical model incorporates several societal areas which affect or condition sickness absence of "all" persons insured in a certain country. Some are supposedly associated with the assumption of the sick role, e.g. sociocultural factors like health beliefs and supply of or access to health care provisions. Other factors (income replacement programmes, company strategies) are more likely to affect subsequent stages of work incapacity: the adoption of the dependent patient role (reporting sick) and the moment and mode of its completion.

Within our explanatory research design and due to available information (research findings, expert opinions) we will firstly concentrate our examination on social security "system-intrinsic" determinants of sickness absence. That is to say: contents, operation and interrelationships of income replacement programmes, which may affect the composition of the employed working age population, its sickness absence behaviour or both.

In Section 10.2 some elements of sickness benefits regulations will further be examined in the light of our findings. In considering how far the operation of invalidity benefit programmes as well as early retirement or unemployment arrangements may account for cross-national differences will be discussed in Section 10.3 and 10.4, respectively. Secondly, some light will be thrown on the weight of health related and socio-cultural factors. Whether lower sickness absence in the Belgian and German populations may be attributed to a comparatively better health status or health behavior will be considered in Section 10.5. Finally, an attempt will be made to compare socio-cultural aspects like value orientations and work-related attitudes in employees from our countries under study (Section 10.6).

The measurement and interpretation of societal factors did lean heavily on available statistics and surveys, whereas some local experts provided indispensable feedback. Notwithstanding the many restrictions of these sources, the comparisons made in this chapter may contribute to a better insight in the role of some country-bound conditions for internationally diverging sickness absence rates.

\subsection{Sickness benefits programmes reviewed}

\subsubsection{Certification and waiting days}

In the preparatory stage of our study we have already described some elements of the income replacement schemes in our countries under study (cf. Chapter 3). In interpreting our findings some major features of these arrangements will now be compared further. 
Within our countries no empirical evidence seems to be available on the effects of certification procedures on absence taking behaviour. As Silomon (1978) stated, medical certification has a double function and incorporates a regulating task for the physician with important social consequences. It is not only a means for the employee to obtain (financial) benefits but also a legitimation for not being able to fulfill the employee role and instead adopting an equivalent role (dependent patient). Not only divergent expectations from various actors (patient, social insurance body, employer) may complicate the certification task. Also the high dependency on the information given by the patient may give a weak basis for diagnosis and prognosis. Further it has been stated that lack of knowledge about occupational backgrounds of the insured may limit the medical practitioners expertise to state validly whether incapacity is real or not (Lebeer, 1981). Finally, a recent inquiry into the tasks and cooperation of physicians in work incapacity procedures indicated the economic importance of obligatory certification should not be forgotten (Andriessen et al, 1985). Economic effects of certification do not only concern the physicians income, directly (doctors fees for the performed consultation) and indirectly (a non-compliant attitude may reduce the practitionners number of patients). Compulsory certification may also increase the costs of medical care. In general, consulting the general physician not only results in written medical evidence of work incapacity, but mostly goes with curative measures like medication and laboratory tests (cf. Section 10.5). Without the certification requirement the insured might, in case of minor ailments, take some days rest or use selfmedication and continue working, without additional health expenditures.

Our review of literature and information from local experts both in Belgium and Germany indicates the effects of statutory medical legitimation are being considered arbitrary. Taking account of these hesitations one conclusion can be drawn: for Belgian and German employees the act of reporting sick clearly is not as anonimous and simple an action as the telephonic notification made by the Dutch employee or his relative. An "institutional obstacle" like certification probably only affects cases with a considerable degree of decision freedom like vague complaints or minor ailments. In these instances the extra steps to be taken under Belgian and German conditions (the decision to report the health situation to a doctor, time lost in the waiting room, consultation) will presumably prevent some of potential notifications. Consequently, the $50 \%$ lower incidence of very short spells (lasting one till three days) in Belgian and German insured, may partly be attributed to this requirement.

In Dutch and German arrangements waiting days have been suspended or abolished; for Belgian employees, however, one statutory waiting day is still applied. In Chapter 6 it has been found Belgian employees take about half as many one-day spells compared to their German and Dutch colleagues (cf. Figure 6.4). But a prolonging effect towards more spells lasting over two weeks (when the waiting day is suspended), as found by Adriaenssens (1985), could not be observed in our data. It may be concluded that, within the context of sickness absence policies in Belgian firms, the application of one waiting day is likely to contribute to the low frequency of one-day absences in Belgian employees. 


\subsubsection{Benefits levels and medical supervision}

The level and payment of benefits clearly creates a dichotomy in our group of countries. Belgian employees are faced with a considerable drop of income after four weeks of work incapacity, although (many) employers seem to provide a temporary supplement to cash benefits for long engaged employees. For the majority of German employees benefits equal net daily earnings, whereas under Dutch regulations being sick also does not imply net financial consequences for the employee.

The analysis of the duration patterns in Belgian personnel did not indicate a substantial drop in absences after entering the period of income reduction (fifth week of work incapacity). In German employees still some accumulation of spells could be noted in the sixth week of work incapacity, the final week of full wage payment (cf. Figure 6.5). Notwithstanding, for a longer period the considerable $40 \%$ gross (20\% net) income loss experienced under the Belgian scheme will certainly affect the length of spells and work resumption patterns. However, it was often suggested during our inquiry that this effect should not be overrated. Due to the considerably higher labour force participation of females a temporary income reduction would often only partly affect the family budget.

Not only financial incentives may to some extent account for observed differences in long-term sickness absence. Also the mode of claim supervision can be expected to exert some influence on work resumption patterns. As only little information could be found our insight in this aspect will be poor. In the Belgian context private insurance doctors, operating on behalf and request of the employer, usually only assess work incapacity within the first week of sickness absence (Klaric, 1982). In how far these evaluations are being made is unknown. Further, sick fund medical officers mainly supervise during the period of benefits payment. Compared to German and Dutch colleagues the work resumption rates of their claimants may be higher. For under Belgian legislation with a more stringent criterion a loss of work incapacity of less than $2 / 3$ already formally implies fitness for work.

A German source indicated (in 1985) only $2.8 \%$ of all work incapacity spells have been medically evaluated by the "Vertrauensärztliche Dienst".(1) Further the German social security doctors showed a high degree of specialization: about $55 \%$ of these experts were specialized, in majority in internal medicine. In the Dutch system lay surveillance and medical supervision of work incapacity takes a more prominent role (cf. Section 3.2). Most occupational associations and "own risk-bearers" employ lay inspectors for a first check of legal requirements. Subsequently, after a few days or weeks the sick employee is invited to a examination by the social insurance doctor. In 1983 about 32\% of sickness absence spells have - at least once - been inspected by the physician: in 1987 this percentage had been reduced to $28 \%$.(2) Our data illustrate under the Dutch scheme the absence of compulsory certification is being substituted by a high commitment of medical expertise during work incapacity.

Not only quantitative but also qualitative differences may be noted between Belgian/German and Dutch physicians activities, however. Under Belgian and German conditions the long term sick employee will regularly see his 
attending doctor to obtain treatment and renewal of the work incapacity certificate. Moreover, in due course the evaluation will be taken over by the insurance doctor operating on behalf of the sick fund or accident insurance.

In the Netherlands the supervision of long term sickness is often not optimally functioning. This is partly due to a lack of interest and cooperation on the side of curative physicians, who hesitate to give information on treatment, prognosis, recovery or residual impairments. This attitude leans on ideas on separation of treatment and evaluation (cf. Section 3.2) and is strengthened by conflicts on doctors fees.

Furthermore, competition has been growing in the relationship of insurance doctors with occupational physicians. Namely, social insurance doctors activities are no longer restricted to medical evaluation, but they increasingly counsel sick employees, and give preventive advice regarding safety and health issues to firms with high sickness absence levels (Pasmooij, 1981; Soeters \& Prins, 1985). Finally, several investigations showed the difficulties of social insurance doctors (as well as general physicians) in managing the duration of illness. Considerable uncertainty about the length and poor prognosis on the moment of partial or full resumption of work were noted by Wiersma (1980) and Groothoff (1986).

Neither the Belgian and German situation nor the Dutch institutional context allow clear outcomes on effects of social insurance physicians activities. Compared to the activities of general physicians, in all countries comparatively little is (publicly) known about expertise, quality and outcomes of insurance doctor performances. Merely the impression is gained that all systems handle the "supply" of work incapacity in their own historically developed ways, without (need for) satisfactory insight into effects.

In Section 3.7 considerable differences have been described for the executive procedures and benefit levels in case of sickness. Some additional conclusions may now be drawn accounting for company strategy differences (noted in Chapter 9). Firstly, the relatively high number of short term absences (lasting 1-7 days) in the Dutch group seems to be considerably associated with the uncomplicated way of notifying work incapacity, as no medical consultation and certificate is required. Also in these less serious cases the resumption of work will often take place on the initiative of the employee, without intervention of social security officials. Most administrative barriers to report sick and extended supervision methods have been found in the Belgian system (strict certification, incomplete reimbursement of medical expenditure of consultation, variety of medical supervision strategies). Secondly, the low rates of long-term sickness absence under the latter system may considerably be attributed to the financial incentive of serious loss of income as well as supervision procedures. This financial condition is absent in the German and Dutch scheme; their diverging rates are probably more due to different employer strategies regarding sick employees (cf. Section 9.5) and other institutional factors. In particular differences in qualifying criteria for invalidity pension payment and variations in the medical assessment process may account for observed highly dissimilar rates of long term sickness absence. 


\subsection{The role of invalidity pension programmes}

\subsubsection{Major dimension of national arrangements}

Invalidity pension programmes can be related in a twofold way to sickness absence levels in a country. Firstly, by requiring a certain period of work incapacity as a qualifying condition to invalidity pension award. Secondly, the disability scheme affects the composition of the employed population, by regulating which persons with deteriorated health and work capacity may leave employment, and which have to stay in the labour market as they do not meet eligibility criteria.

The invalidity pension arrangements operated in Belgium, Germany and the Netherlands differ considerably regarding qualifying criteria, benefits level and duration of payment (Copeland, 1981; Haveman et al., 1984; U.S. Department of Health and Human Services, 1988). Some of these characteristics, potentially accounting for cross-national sickness absence differences, have been set out in Table 10.1 .

Table 10.1 Some dimensions of invalidity pension programmes in Belgium, Germany and the Netherlands.

\begin{tabular}{|c|c|c|c|}
\hline & B & G & $\mathrm{N}$ \\
\hline $\begin{array}{l}\text { Minimum reduction of } \\
\text { earning capacity required }\end{array}$ & $66 \%$ & $50 \%$ & $15-25 \%$ \\
\hline $\begin{array}{l}\text { Minimum contribution } \\
\text { period required }\end{array}$ & 6 months & 60 months & none \\
\hline Benefits payment & $\begin{array}{l}\text { after assessment of } \\
\text { disability and one } \\
\text { year sickness } \\
\text { benefit payment }\end{array}$ & $\begin{array}{l}\text { after assessment of } \\
\text { of disability }\end{array}$ & $\begin{array}{l}\text { after assessment } \\
\text { of disability and } \\
\text { one year sickness } \\
\text { benefits payment }\end{array}$ \\
\hline Cash benefits & $\begin{array}{l}45 \% \text { of earnings } \\
\text { (single), } 40 \% \text { (couples } \\
\text { with two incomes), } \\
65 \% \text { (with dependents) } \\
\text { with fixed minimum } \\
\text { and maximum }\end{array}$ & $\begin{array}{l}15-80 \% \text { of earnings } \\
\text { (occupational } \\
\text { invalidity: } 1 \% \text {, } \\
\text { general disability } \\
1.5 \% \text { for each year of } \\
\text { insurance) }\end{array}$ & $\begin{array}{l}\text { varies according } \\
\text { to degree of } \\
\text { disability from } \\
20-70 \% \text { of } \\
\text { previous earnings } \\
\text { with maximum (a) }\end{array}$ \\
\hline Duration of payment & $\begin{array}{l}\text { up to normal } \\
\text { retirement age } \\
\text { ( } 65 \text { years males; } \\
60 \text { women) }\end{array}$ & unlimited & $\begin{array}{l}\text { up to normal } \\
\text { retirement age } \\
\text { ( } 65 \text { years) }\end{array}$ \\
\hline
\end{tabular}

(a) Most collective agreements provide (tempory) supplement up to $100 \%$

Under the Belgian disability benefit programme just one degree of incapacity is recognised (disabled more than $66.7 \%$ ). The claim for invalidity benefit is initiated by the sick fund, and medically assessed by the insurance phycisian of this fund. In case of continuing sickness the insureds earning capacity is no longer evaluated in the light of his present job (as under sickness insurance), but in the light of general labour market conditions (Geerts, 1976; Maroy, 1989). Sickness benefits recipients who do not meet the comparatively high minimum degree of disability required (and who are out of work) may qualify for unemployment benefits. 
In the German statutory pension scheme two levels of incapacity are being discerned:

a. general disability ("Erwerbsunfähigkeit") which corresponds to a (virtually) total loss of earning capacity; and

b. occupational invalidity ("Berufsunfähigkeit") when the reduction equals at least $50 \%$.

In general the distinction is merely a question of degree, but leading to substantial financial consequences, as the occupational invalidity pension is about one-third lower than the general disability pension (Eidenmüller, 1985). Further, as the definition of disability applied is rather vague, the method of evaluating disability has been influenced by jurisdiction. From 1969 on in determining invalidity a "concrete method" of assessment should be applied, taking into account the availability of suitable jobs for the person with residual capacities. So persons who can only work part time are eligible for a general disability pension when only full time jobs are available on the labour market. (Haveman et al., 1984; Eidenmüller, 1985). Whereas in Belgium and the Netherlands invalidity is considered and administratively handled as a prolongation of sickness, the German invalidity insurance is related to the old-age insurance branch. So sickness benefits must not have been paid previously as a qualifying criterion and the application for a disability pension has to be made by the insured person.

In the Netherlands for employees in the private sector the Disability Security Act ("Wet op de Arbeidsongeschiktheidsverzekering, WAO") came into force in July 1967, and covers the loss of earnings after a full year of sickness. A person is wholly or partially disabled "who as a consequence of illness or impairment is unable to earn from work commensurate with his ability, skill and experience, such a wage as is earned by a similar healthy person in the same place or neighbourhood" (definition cited in: Bruinsma \& Emanuel, 1985). The DSA programme recognises seven degrees of disability, each providing pension as a percentage of previous earnings. The minimum degree of disability or entitlement is $15 \%$. Also in the Dutch scheme the interpretation of the disability criterion has been relaxed (cf. Emanuel, 1980). From 1973 the lack of opportunities on the labour market for "suitable employment" has been taken into account by assessing the highest (80-100\%) degree of disability to partly invalided. Since 1987, however, the non-medical part of assessed disability has to be covered by unemployment benefits (but, so far the implementation of this criterion has not lead to remarkably lower numbers of partially disabled). Admission for invalidity benefits is automatically evaluated at the end of the period of sickness benefit payment ( 52 weeks). The maximum benefit, corresponding to the highest disability class, amounts to $70 \%$ of previous earnings. According to collective labour agreements many employers provide a supplement up to $100 \%$ during some years.

From Table 10.1 it may be concluded eligibility criteria and benefits differ considerably across our countries. The Dutch programme shows least insurance-oriented elements (waiting period, assessment of benefits level) and most favourable payment conditions compared to both other countries. Regarding transfer to the programme the German regulations seem to be most restrictive, and insured should have worked many years to obtain a moderate pension. 


\subsubsection{Invalidity incidence rates compared}

In order to assess the influence of disablement pension arrangements on sickness absence levels we tried to compare some invalidity rates. As was the case with sickness absence figures a cross-national comparison of these indicators meets considerable restrictions due to differences in disability concepts, eligibility criteria, populations covered and measurement strategies. With the constructive help of some local social security experts and laborious processing of (partly unpublished) official data a few estimates could be made allowing some valid comparisons across our nations.(3) Here again we will as far as possible restrict our analysis to the insured employees in the private sector, in particular the working-age population, up to 64 (or 65) years. For optimal conceptual equivalence in German rates the occupational and general disability rates have been combined (cf. Mörschel \& Rehfeld, 1981; Kentner et al., 1983). For the Dutch population all insured and recipients of a DSA benefit will be covered. Restriction of the analysis to the large majority of beneficiaries with over 55\% disablement (to "match" foreign minimum degrees of disability) would truncate our attempts seriously.(4)

As in most industrialized countries also in Belgium, Germany and the Netherlands the number of disability benefit recipients increased in the last two decades. In Belgium the number of beneficiaries steadily doubled in twenty years, being about 165.000 in $1987(5)$ Under the German system the number of recipients of occupational and general disability pensions increased to 2.37 million (1983) but declined afterwards. This drop is due to the introduction of new flexible retirement options and the exclusion of some categories of previously insured (who are not actively paying contributions) since 1984. The steepest rise in awards of disability benefits may be observed in the Netherlands: the number of DSA-recipients increased from 1967 (introduction of DSA) to 1987 by about 400 percent.

Figure 10.1 Number of invalidity pension recipients per 1000 insured in Belgium, Germany and the Netherlands at 31.12 (1970-1987)

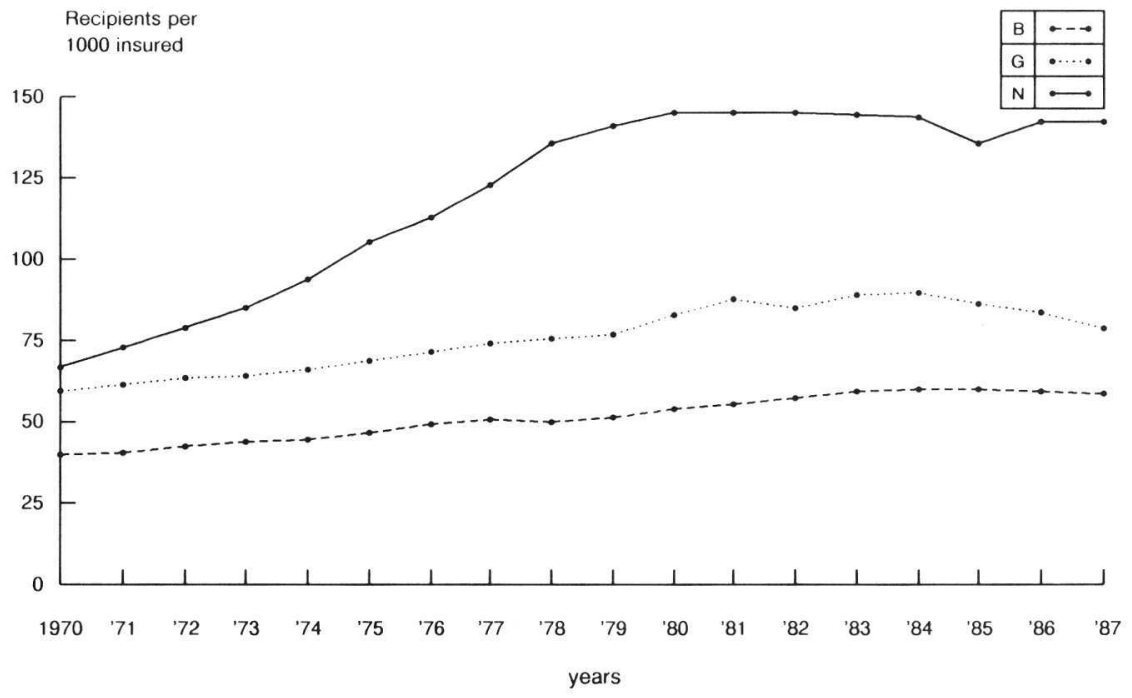


Relating the number of beneficiaries to the population of insured (cf. Figure 10) it becomes obvious that in the Netherlands the increase has stabilized since 1980 (although absolute numbers of recipients are still growing).

Age-specific dependency ratio's indicate that in particular employees aged over 54 years contributed to the large Dutch population of beneficiaries. Whereas in the German and Belgian system per 1000 insured aged 55-64 only 262 and 434 receive invalidity pension, respectively, under the Dutch system in this category 980 persons (891 persons with a disablement degree over 55\%) are awarded benefits in 1987. It may be concluded that in the Netherlands about every second person aged 56-64 does receive some invalidity pension whereas in Belgium every fifth person left the work force this way.

The role of invalidity pension schemes regarding long term sickness absence can be more closely considered by making a comparison of annual invalidity incidence rates. This indicator measures the number of new recipients per 1000 insured in the population at risk, the latter being defined as the number of insured persons in the previous year(6) (Halin, 1988). For the observation period 1980-1987 average invalidity incidence rates were 8.5 and 9.7 in the Belgian and German populations, respectively. In the Netherlands for this period yearly 16.6 new entrants were noted per 1000 insured. These rates, however, do not account for population differences, which particularly concern the German population, as it comprises considerably higher proportions of females and insured aged over 44 years. Therefore, age-specific incidences were calculated (standardized for sex) which show a major similarity: in all countries invalidity incidence increases with age (cf. Figure 10.2).

Figure 10.2 Average yearly number of new invalidity benefit recipients per 1000 insured by age group in Belgium, Germany and the Netherlands (1980 - 1987).

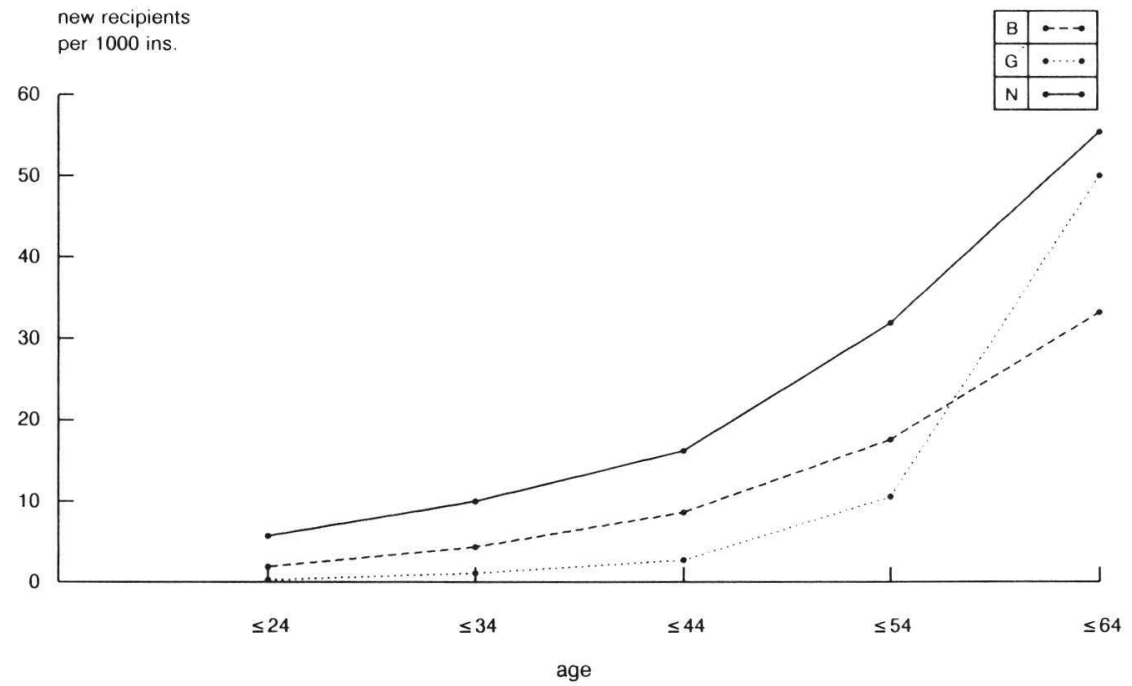


In Dutch insured a very steep rise in the number of new awards with increasing age is obvious whereas under both other schemes increases are less extreme, with an exception of the oldest age group in the German population. It may be concluded the two times higher frequency of invalidity benefits recipients in the Dutch population is a general phenomenon which is not concentrated in the highest age group, as in the Belgian, and, in particular, in the German situation.

As similar relationships of incidence rates to age have been established we may account for insured population differences between our countries by applying a direct standardization to age and sex. The Dutch population of insured in 1980 has been chosen as a standard; by selecting this year (first year of our observation period) we also may control for ageing effects in our three populations (cf. Figure 10.3).

Figure 10.3 Standardized invalidity incidence rates in Belgian, German and Dutch insured (1980-1987)

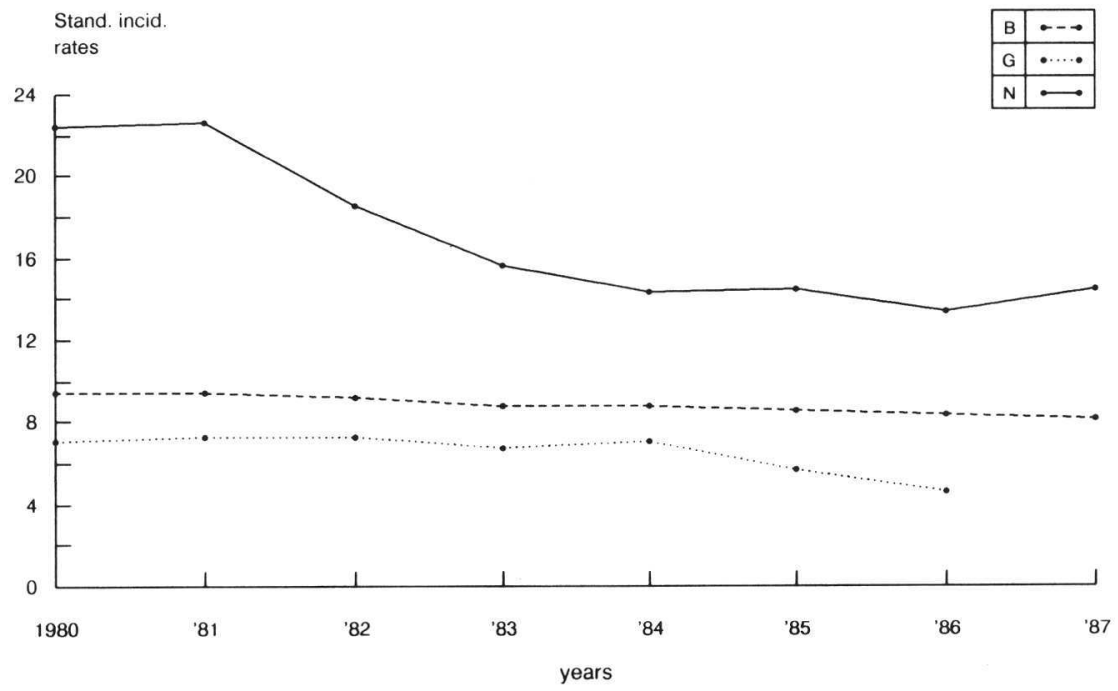

In Figure 10.3 national invalidity incidence rates have been depicted as if populations had the same composition regarding age and sex distribution. It indicates in the Netherlands yearly about three (1980) and, more recently, about two (1987) times as many new disability recipients may be noted compared to the Belgian and German system. It may be remembered one year of work incapacity does more or less automatically qualify for invalidity benefit transfer in the Netherlands; also in the Belgian system claims for invalidity benefits are mostly preceeded by one year of sickness benefits. Now the conclusion is permitted that in the Netherlands the DSA programme accounts for about $100 \%$ more sickness absence days in insured than under the Belgian scheme. These effects are most strong in the younger age groups 
with Dutch invalidity incidence rates exceeding Belgian and German levels about five times (insured aged up to 24 years), decreasing to 1.5 times (in the age group 55-64 years).

\subsubsection{Administrative and epidemiological aspects of invalidity}

Claims to invalidity benefits have to be evaluated in the light of legal requirements. Under the Belgian scheme about $90 \%$ of claims for invalidity benefits are being awarded yearly, permanently or temporal.(7) German statistics indicate in average only $64 \%$ of claims for a specific or general invalidity pension have been accepted between 1980 and 1986. For the Netherlands also a high acceptance rate may be noted: in average only 93\% (1980) - 85\% (1987) of insured with (nearly) 52 weeks of work incapacity are being transferred to the DSA-programme. This high acceptance rate should of course be considered vis-à-vis the relatively low threshold in the latter scheme (as minimally 15$25 \%$ of disability is required). Alas our data do not indicate whether the large differences between Belgian and German acceptance rates derive from the application of different assessment criteria vis-à-vis presented health and earning capacity reductions or from selection processes in the pre-invalidity stage (persons with deteriorated health leaving jobs due to lay-offs or by using early retirement options.)

A first impression of underlying health problems may be derived from the comparison of major diagnostic groups of new benefit recipients. ${ }^{(8)}$ Before interpreting our data it should be noted that differences observed may also reflect cross-national variations in the use of diagnostic terms and criteria (Pflanz, 1975; Payer, 1989). The crude major diagnostic pattern of newly invalidated per 10.000 insured has been depicted in Figure 10.4

Figure 10.4 Main diagnostic groups in new invalidity benefit recipients per 10.000 insured (1980-1987) in Belgium, Germany and the Netherlands

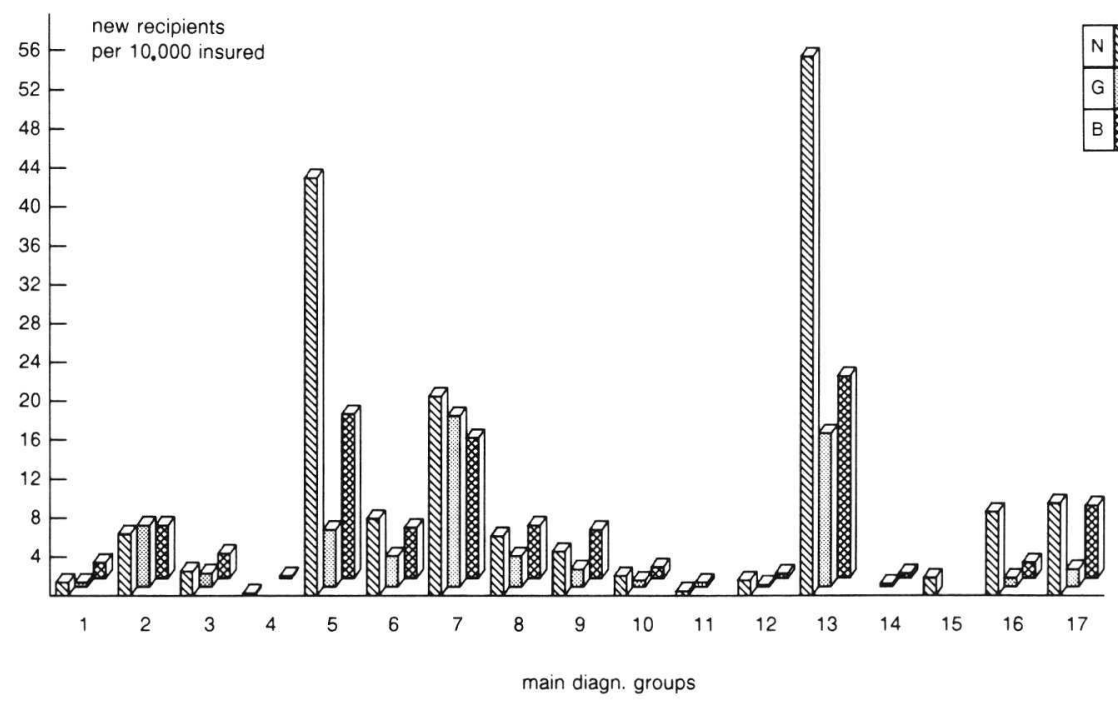


The national distributions show many similarities regarding diagnostic groups with high and low incidences. Strikingly higher rates in Dutch "entrants" may be observed for "Mental disorders" (group 5) and "Diseases of the muscoskeletal system" (group 13). Differences are most extreme between the German and Dutch recipients (cf. group 5, 13, 16, 17), which to a certain extent will be explained by age differences of entrants.

The Belgian population of insured however, considerably resembles the Dutch population as to age structure in male and female insured. So the $150 \%$ higher Dutch incidence rates for insured with mental disorders and muscoskeletal diseases should probably be attributed to epidemiological and psychosocial factors (objective and subjective health status). But also factors in the executive organization may account for the higher Dutch proportions of these two - difficult to diagnose - types of impairments. Hogerzeil already noted that after some months somatic and psychic complications are becoming more important (cf. Section 7.4.2). Recently some inquiries confirmed that prolonged sickness absence aroused feelings of depression or powerlessness and emotional strains which increased disablement (Van 't Hullenaar \& Van Koningsveld, 1986). Furthermore the ways social insurance officials (doctors, labour experts) evaluate the health status and earning capacity of pension claimants (cf. Section 10.5) may also account for these cross-national variations.

The duration and mode of termination of invalidity pensions highly affects the number of disabled and their re-entry on the labour market. Therefore, we compared "completion patterns" of invalidity pension recipients in the countries under study. The comparison of recent yearly ratio's of "entrants" (new recipients) and "leavers" from the invalidity pension schemes indicates different patterns. (9) In average the number of entrants in the Belgian system nearly equals the number of leavers (1983-1987). Under German arrangement since 1985 more leavers than new beneficiaries may be noted whereas in the Dutch system the yearly number of entrants consistently exceeds the category of leavers by $5 \%$ in average.

As also the completion of invalidity benefits will be associated with age (e.g. transfer to old-age pension) age-specific completion rates were compared for the three systems. The rates cover a five-year period and were directly standardized for sex (taking the Dutch population as a standard). Now for almost all age groups striking differences are demonstrated between exitpatterns of Belgian, German and Dutch invalidated (cf. Figure 10.5).

Under Belgian regulations per 1000 invalidated aged under 24 years on average about 500 leave the programme, but under Dutch conditions only 107 completions may be noted (Germany: 309). Also most other Belgian and German age groups show 2-3 times more leavers compared to the Dutch situation. Only for the highest age group Belgian and Dutch recipients show higher completion rates (which are due to the inclusion of transfers to normal pension). Directly standardized termination rates (as to age and sex) indicated per 1000 beneficiaries in average 136 leave the Belgian programme whereas only 68 complete receipt of DSA-benefits in the Netherlands. In the German system 58 persons left the programme which is mainly due to the deviant age structure of German recipients (high proportion aged over 55 years). 
Figure 10.5 Average yearly number of terminations per 1000 invalidity benefits recipients by age-group in Belgium, Germany and the Netherlands (1983-1987)

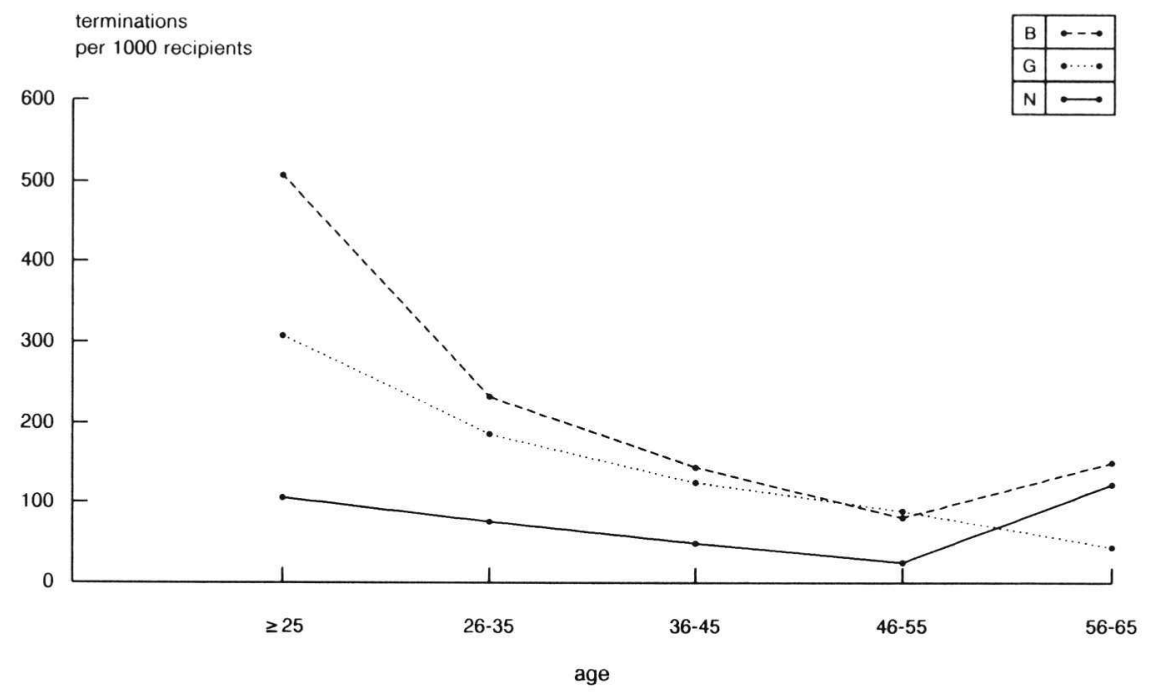

It may be concluded under the Dutch scheme being assessed as disabled is a much more permanent status than under Belgian regulations. This is illustrated by the weak association of age group to completion rates in the former system, whereas in Belgian and German recipients a strong and inverse relationship is obvious.

Finally, inspection of the causes of termination may provide further insight into the operation of invalidity pension schemes. To that end Table 10.2 demonstrates the completion grounds as published in official sources.

Table 10.2 Reported causes of invalidity benefits completion in Belgium, Germany and the Netherlands (1983-1987)

\begin{tabular}{lccc}
\hline Causes & B & G & N \\
\hline Recovery & - & - & 30.1 \\
Work resumption & 11.7 & - & - \\
Death & 18.1 & 27.3 & 14.7 \\
Old-age pension & 34.4 & - & 54.1 \\
Exclusion & 30.8 & 9.9 & - \\
Transfer within pension programme & - & 60.9 & - \\
Other & 5.0 & 1.9 & 1.9 \\
\hline Total & $100 \%$ & $100 \%$ & $100 \%$ \\
\hline
\end{tabular}

The overview illustrates a direct comparison being complicated as completion causes differ between systems and do not cover similar situations. E.g. "recovery" under Dutch conditions indicates "exclusion" due to no longer fit- 
ting to the minimal invalidity degree (15-25\%). Consequently it does more resemble "exclusion" than "work resumption". With some restrictions it may be concluded:

a. in all systems for the majority of cases the disabled status means a permanent position outside the labour market;

b. re-entry into the work force seems to be a major termination ground under the Belgian scheme and is least found in the German exit patterns;

c. mortality seems to be not equally distributed in recipients of invalidity benefits in our countries under study.

How far these differences are due to variations in health status of beneficiaries can also be explored here. As death rates are generally considered as a crude health indicator unstandardized mortality rates in invalidity benefit recipients have been calculated(10) (cf. Figure 10.6).

Figure 10.6 Mortality rates in Belgian, German and Dutch invalidity benefit recipients aged under 65 (1983-1987)

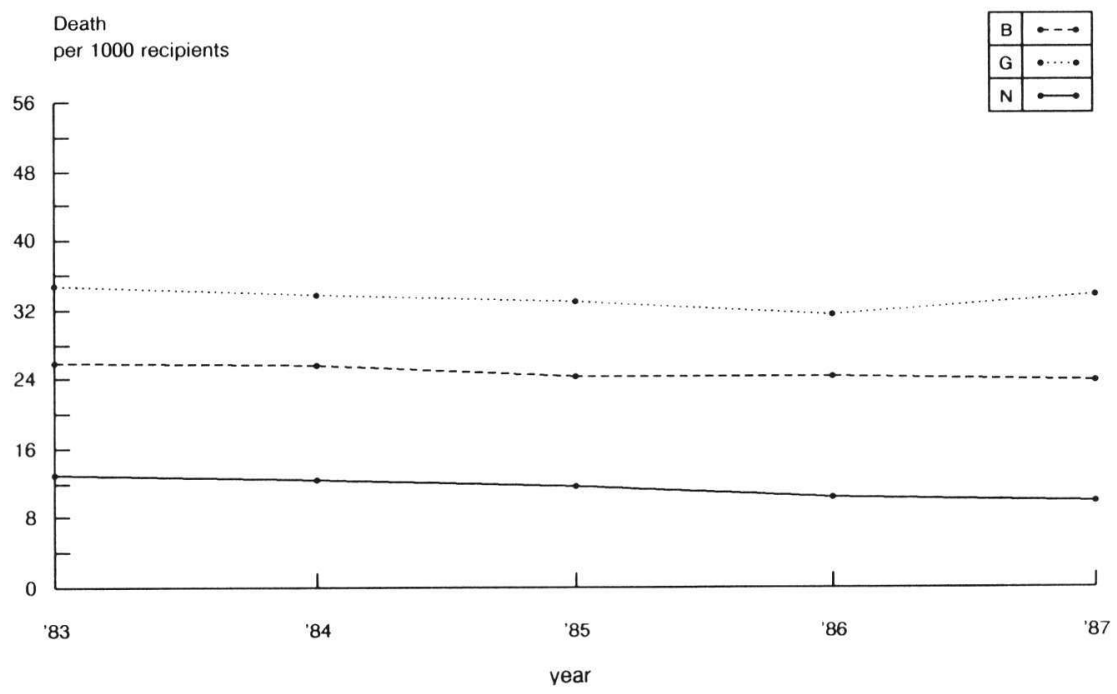

Generally speaking mortality rates in the Belgian and German population are to be two and three times higher respectively, than in Dutch invalidity pension recipients. From an epidemiological point of view we may conclude the health condition of Dutch benefit recipients is more favourable than the health status of Belgian and, in particular, German beneficiaries. This may partly be due to the inclusion of Dutch recipients with relatively low degrees of disablement, although about $82 \%$ still fall into the highest category of being incapacitated for $80-100 \%$. Age composition also will relate to mortality differences, in particular regarding the German beneficiaries, as Belgian and Dutch invalided show fairly similar age distributions. Finally, here again we find some clues that the pattern of diseases and disorders in claimants underlying disability as 
well as (medical) evaluation methods applied may account for differences observed. Within the constraint of the sources available differences in assessment strategies will not be identified. Only the epidemiological aspect will be considered further in this study (cf. Section 10.5).

\subsubsection{Effects on sickness absence}

Attention has been focused on invalidity benefit programmes as some elements and their operation may affect the incidence and termination of long term sickness absence. Integrating findings from literature, information from experts and our quantitative analysis now allow some conclusions.

Firstly, Dutch eligibility criteria require one year of work incapacity, a minimum degree of invalidity of 15-25 percent, and no minimum insurance contribution periods. These criteria seem to differ most to the German programme requirements. German arrangements show a higher invalidity threshold and lack any formal relationship between sickness and invalidity benefit programme. In this country the length of sickness absence neither initiates claims nor qualification for invalidity benefits receipt. Only periods of insured employment and fulfilment of minimum 50\% loss of earning capacities determine the access to German invalidity pensions. So under German conditions the effects of invalidity pension scheme from sickness absence seems to be weak.

Secondly, more resemblances with the Dutch system could be noted in Belgian arrangements. In both programmes claims to invalidity pension are being evaluated after one year of work incapacity. Moreover, Belgian acceptance rates were quite similar to Dutch figures. In the light of the relatively low number of long term sickness absences and their rapidity of termination (cf. Figure 6.8) another conclusion now may be drawn. Disregarding company strategies, in case of prolonging sickness, low benefit levels seem to "filter" the "supply" of invalidity pension claimants in Belgium. After about one year of work incapacity (about 11 months of $20 \%$ loss of net income) and regular contacts with health care (certification) and insurance bodies a category of (very) seriously incapacitated insured remains, which then "easily" qualifies for the $66.7 \%$ loss of earning capacity and, consequently, invalidity pension award.

Thirdly, the comparison of access and termination patterns evokes questions on the health condition, medical evaluation strategies, and work resumption incentives under the Dutch scheme. Differences may be assumed in the supply of health problems and the assessment of disability, as particularly for diagnostic groups which are difficult to diagnose through objective medical procedures the largest differences were noted (mental and locomotor impairments). Most important for our analysis however seems to be the conclusion that the Dutch invalidity programme in a twofold way is being related to sickness absence, compared to the Belgian and German conditions:

a) Per 1000 insured about twice as many persons complete one year of work incapacity than under the Belgian scheme (with the same waiting period). Consequently, this waiting period requirement shows a far greater effect on 
sickness absence in the Dutch population than on sickness absence in Belgian employees;

b) by transfer (on an almost permanent basis) of insured from the labour market (in particular categories of relatively young insured) a comparatively strong "healthy worker effect" may be expected for the Dutch situation. Subsequently, a stronger sickness absence reducing effect of invalidity pension awards may be assumed in the Dutch system compared to both other countries.

The question may now be stated how other systems, if not by application of the invalidity pension programme, deal with employed persons with (chronic) health problems but who fail to meet invalidity benefit requirements.

\subsection{Further labour force selections: unemployment and (early) retirement}

In case of prolonged sickness in many countries claiming an invalidity pension is self-evident. When eligibility criteria are not being met and work is not resumed, however, two other contingencies may come into consideration, namely unemployment and early retirement programmes.

In case of unemployment and fulfilling further qualifying conditions (insurance period, registration) Belgian employees receive benefits amounting to $60 \%$ of earnings (with dependents) for two years ( $40 \%$ during second year if single), and $50 \%$ of minimum wage thereafter. For German insured unemployment benefits ("Arbeitslosengeld") an amount of $68 \%$ of (after tax) earnings are being awarded (if single: 63\%), in general continuing for 16 to 52 weeks (depending on duration of insured employment). Subsequently unemployment assistance ("Arbeitslosenhilfe") may be awarded ( $58 \%$ of earnings after tax). Under the Dutch scheme unemployment benefits may be awarded, covering $70 \%$ of earnings (up to daily maximum), payable for maximally 26 weeks. After exhaustion social assistance programmes come into force. It may be concluded in general the unemployment programmes applied in our countries under study show many similarities as to qualifying conditions and level or duration of benefits payment.

As a way to relieve the pressure on jobs in the 1970's in Belgium several temporaly flexible retirement provisions have been introduced (André, 1985). Normal retirement pensions are being awarded when insured are aged 65 , and for women when aged 60. "Contractual early retirement" benefits are being paid to persons minimally aged 60 (males) or 55 (females) who are unemployed due to dismissal. Further "statutory early retirement" pensions are awarded to persons aged 60 and over who voluntarily give up their job, under the condition the worker is replaced by an unemployed person.

Due to the poor labour market also the German pension programme substituted the fixed normal retirement age of 65 years for more flexible retirement provisions. Disregarding here the statutory requirements (years of insurance, employment periods) several retirement pensions are now awarded on an optional or compulsory basis (Eidenmüller, 1985):

a. normal retirement pension, payable at 65 th year;

b. deferred retirement pension, payable later than 65 years, which give the insured the opportunity to meet eligibility criteria for normal retirement pension; 
c. early retirement pensions, awarded to insured aged 60 when unemployed, severily disabled; also to women who choose to stop working at the age of 60 ;

d. advanced retirement pensions awarded to insured who voluntarily choose to stop working at the age of 63.

The Netherlands seem to take an exceptional position in Europe on this issue, as there are no statutory provisions for men and women for early retirement before age 65 . Only in several branches and firms private supplementary schemes provide interim benefits for workers opting to retire early from age 60 (VUT plans). In 1987 about 50\% of employers in industry and commerce provide such arrangements, which are being used yearly by $0,7 \%$ of employees (Centraal Bureau voor de Statistiek, 1988; Blomsma \& De Vroom, 1988). The percentage of males aged 55-64 who had stopped gainful employment this way rose from $6 \%$ (1977) to $23 \%$ (1986), now being equal to the proportion of disabled in this age category (Centraal Bureau voor de Statistiek, 1984, 1987). In addition to these provisions employees may receive extra annual leave periods in the years immediately before retirement (International, 1982). Comparable data are poor; our few figures suggest that in the Netherlands early retirement arrangements are comparatively less developed than in surrounding countries and therefore restrict the opportunity for employees of advanced age to leave the work force.

\subsection{Cross-national differences in health status}

The second societal complex of factors affecting sickness absence to be considered refers to the health status of the employed. Principally a major initial condition for the occurrence of sickness absence is the existence of a temporaly or chronic reduction of health which affects the earning capacity. The individual's health status, both its biomedical component (disease) and its subjective experience (illness), were considered as the first step in the chain of events and decisions underlying sickness absence behaviour (cf. Section 7.4.2). Therefore, in a cross-national inquiry an attempt at a comparison of health conditions is impending.

This comparison, however, faces even more difficulties than was the case with bare sickness absence or invalidity rates. Health status can only be measured in a global and indirect way and then it is severely confounded by economic, medical, social and historical factors. Sometimes the use of health care facilities (consultations, hospital admissions, etc.) is being compared, but this indicator is often heavily biased by supply side factors (Peeters et al., 1985). We will focus our comparison on two kind of indicators:

a. two widely used global measures of health: death rates and life expectancies;

b. some measures of health behavior, like risky habits and medical consumption.

Other indicators (e.g. morbidity rates, health interview survey data, etc.) are not available or hardly comparable due to definition and measurement incongruities. Most of these health indicators applied here are based on measurements of the entire population in a country or expressed as "per capita" rates. We will assume that employees, literally being the results of "healthy worker" processes, to a large extent will reflect the cross-national differences observed in entire population data. 
Mortality rates are traditionally considered as reliable indicators of the health condition, although they are less sensitive to shifts in disease patterns in modern society (e.g. from acute lethal infections to chronic diseases). According to (age-) standardized mortality rates Dutch persons have a more favourable health condition than Belgians and Germans (Mackenbach, 1989). Populations in the latter countries show considerably higher mortality, the gap being widest between Belgian and Dutch levels.

Table 10.3 Selected classic bealth measures in Belgium, Germany and the Netherlands

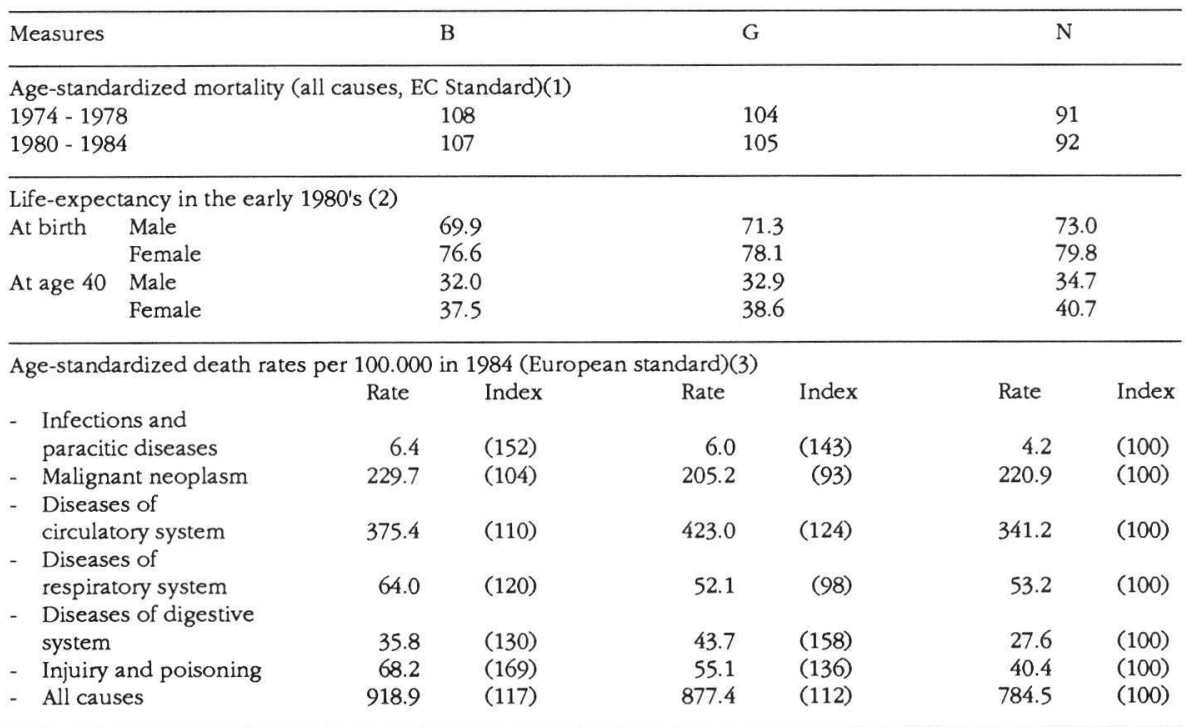

Sources: (1) Mackenbach, 1989

(2) OECD, 1987, Table 12, 13

(3) OECD, 1987, Table 15

Life expectancy at birth and at age 40 reflect similar variations. Life expectancy is about two and three years higher in the Netherlands compared to Germany and Belgium, respectively. At (average working) age of 40 the largest differences may be noted between our countries. Finally age-standardized mortality rates for major causes of death also indicate considerable differences between our countries regarding the mortality of selected diseases. Except for digestive system diseases for all selected diseases considerably higher death rates are found in the Belgian population compared to the Dutch population. Higher German rates seem to be more disease-specific. Investigations on regional mortality rates did not indicate extent and supply of health care but merely factors in life style and in socio-economic structure account for these cross-national differences (Philipsen, 1985).

For the life style factor some empirical support could be found as is shown by the indicators of health behaviour and life style depicted in Table 10.4.(11) In general they confirm the differences already observed between our three countries, although Belgian and German rank positions sometimes shifted. 
Table 10.4 Selected bealth behaviour indicators for Belgium, Germany, the Netberlands

\begin{tabular}{|c|c|c|c|}
\hline Indicator & B & G & $\mathrm{N}$ \\
\hline \multicolumn{4}{|l|}{ Alcohol consumption per capita (1984) } \\
\hline - distilled (liters 100\% alcohol) & 1.9 & 2.3 & 2.4 \\
\hline - beer (liters) & 126.3 & 144.4 & 83.4 \\
\hline - wine (liters) & 22.9 & 25.7 & 15.2 \\
\hline \multicolumn{4}{|l|}{ Traffic accidents (1985) } \\
\hline - injured per 1000 inhabitants & 7.56 & 6.92 & 3.34 \\
\hline - deaths per 1000 inhabitants & .18 & .14 & .10 \\
\hline \multicolumn{4}{|l|}{ Medical consumption (1980) } \\
\hline - outpatient physician consultations & 7.1 & 10 & 3.2 \\
\hline - pharmaceutical expenditures per capita (US\$) & 127.8 & 194.1 & 104.3 \\
\hline - number of pharm. prescriptions per 100 physician consultations & 92 & 194 & 58 \\
\hline
\end{tabular}

Regarding risky habits the Dutch show lower consumption rates of alcohol compared to Belgian and German inhabitants, although recent figures indicate these differences are declining (Casselman \& Knibbe, 1985). Notwithstanding, alcohol consumption is still lowest per capita in the Netherlands and $50-70 \%$ higher in Germany. Smoking habits do not seem to differ between our countries but risky behaviour in traffic seems to be more prevalent in Belgium. Finally, taking account of their restricted validity(12) medical consumption rates (consultation, pharmaceuticals consumed) also indicate considerable differences in illness behavior. Physician consultations and pharmaceuticals are considerably less used in the Netherlands compared with Belgium, and, in particular, Germany.

How far cultural factors (e.g. tolerance of pain and discomfort), economic aspects (e.g. compulsory legitimation of dependent patient role) or health care conditions (e.g. payment arrangements) may account for these striking differences cannot be answered in our study. It may be concluded that our selection of health status and health behaviour indicators quite unanimously indicate a remarkable pattern of differences between our countries under study. Enterlines 25 year old observation (cf. Chapter 2) on an inverse relationship of sickness absence rates to mortality rates still seems to hold (on country level). Also our inquiry demonstrates that the Dutch population in general seems to enjoy a comparatively better health status and a healthier life style than their neighbours. But a considerable and similar subset from each population, the employed, show an opposite pattern when work incapacity is concerned. The examination of this apparent contradiction will be one of the themes in our final chapter.

\subsection{Work-related values and attitudes}

In Chapter 2 we noted some authors suggest cross-national differences in sickness absence particularly reflect a contrast in "work ethic" or views about work. Also in our analytical framework socio-cultural work-related factors, like labour orientation and perceived job security, are assumed to affect sickness absence behaviour (cf. Section 7.4.2). In this section we will attempt to compare our countries as to work-related values, attitudes and perceived wor- 
king conditions. This exploration may show whether our populations (also) differ in these aspects. However, labour orientations (values, attitudes) as well as (subjectively) perceived working conditions are difficult to study comparatively. Differences in social systems, tradition, labour relations but also restrictions in comparable measurement complicate drawing of valid conclusions. Investigations accounting for these factors are quite rare and generally rely upon surveys of workers attitudes and views. A direct causal linkage to sickness absence will stay out of sight, but our conclusions may add to the interpretation of our earlier findings.

For our countries and subject we only found four comparative studies which had been carried out on a uniform basis (similar methods, same questionnaire, similar sample). Firstly, the unusually vast investigation comparing workrelated values in 40 countries made by Hofstede has alreay been introduced in Section 7.4.3. Data were collected around 1968 and again around 1972 and concerned attitudes, preferences and perceptions about work. The author identified four main dimensions of culture which are being reflected in the prevailing norms and values in a country. Regarding work-related values some substantial differences could be observed in employees from our three countries:

- Belgian employees experienced and accepted considerably more inequality in the company (and society) than their German and Dutch colleagues, who seemed more "prone" to question authority and to disagree with their supervisor;

- Belgian workers also experienced more job stress and saw loyalty to the employer more as a virtue than employees in both neighbour countries;

- Belgian, German and Dutch employees showed just minor differences in individualism (e.g. importance of personal life, time, etc.);

- The dominant sex role pattern in German and Belgian employees workrelated cultures showed to be much more "masculine" than in the Dutch value system. Cooperation, levelling and lower job stress is rated high by Dutch personnel whereas performance, excelling and more industrial conflicts could be associated with the other nationalities.

The overall picture indicated that Dutch and German employees showed most similarity in work-related value preferences whereas remarkably large differences were found vis-à-vis Belgian employees.

In 1981 an extensive study was made of the moral and social values in ten European countries (Stoetzel, 1983; Harding et al., 1986). The characteristics persons valued in a job were shown to contain three major dimensions, namely personal development (the intrinsic content of a job), pleasantness (job conditions, work environment) and security and award aspects (pay, promotion). On all three job values German respondents attributed more weight than respondents from other countries. Personal development was rated considerably lower in Belgian and Dutch respondents. Further only the Dutch placed less importance on material aspects of jobs.

Regarding job satisfaction variations between Belgians and Dutch were not considerable but surprisingly substantial lower scores were found in German respondents. Finally, on "orientation to work" (motivation) highest ratings 
were found in the Dutch group; here again German respondents scored remarkably lower. As the findings for Germany may seem contradictory, the authors state the greater salience of work among Germans may lead to higher expectations and "a sharpened perception of the gap between the "ideal" qualities of a job and the realities of work experience" (Harding et al., 1986, p. 168).

In the same period another multi-national investigation focussed on the "meaning of work" in respondents from four European countries, Israel, Japan and the USA (Drenth, 1983). Regarding our countries the inquiry partly showed similar findings here: again Dutch respondents demonstrated lowest scores on the "economic motive" for working. But regarding the "centrality" of work in personal value systems not only Dutch respondents showed low scores. According to this inquiry also in German respondents comparatively less persons attributed a dominant role to work.

Most recently a cross-national investigation on "Employee attitudes towards their employers", carried out in 1985, supports several earlier findings (International Survey Research Limited, 1987). Dutch employees rated their companies most favourable on 10 out of 14 dimensions. German employee attitudes were also considerably positive, whereas Belgian employees generally showed lowest ratings. On several dimensions Belgian employees scores deviated notably from German and Dutch evaluations, e.g. regarding attitudes towards company management, immediate boss, working relations and communications. Also on pay, company benefits and job security Belgian employees were more critical than German and Dutch employees. In two dimensions the Dutch differ remarkably from employees in both other countries: physical working conditions and job satisfaction received more positive ratings than in Belgium and Germany.

A weaker comparison of German and Dutch evaluations, based on separate inquiries, suggests more similarities. Regarding working conditions (noise, safety risks, monotony, etc.) no systematic differences could be found between respondents from both groups. But career opportunities are regarded much more favourable by German persons (76\%) than by Dutch $(28 \%)$. On job satisfaction too our countries diverge remarkably. Whereas $77 \%$ of Dutch persons reported to be (very) satisfied with their job, only 39\% of German respondents had the same opinion (Noelle-Neuman et al., 1985; Centraal Bureau voor de Statistiek, 1984).

Comparing the findings on work-related values and attitudes there is some danger that differences are suggestive of stereotyping. The complexity of variations and heterogenity of research results, however, may resist these attempts. Only on a few work-related cultural dimensions research findings are quite consistent, but on several others there is more dissimilarity. Variety in research methods applied but also shifts in preferences may underly the limited congruity of findings.

All sources indicated, however, the economic aspects of work (pay) are considered more important for German and Belgian respondents than for Dutch; the latter attribute comparatively more weight to non-material aspects of jobs (e.g. working relations). Belgian employees seem to be most critical on pay and company benefits. These conclusions are quite understandable in the light of our findings of benefit systems. 
A second quite unanimous conclusion regards the relatively high degree of job satisfaction in employed Dutch. In all studies considerable lower ratings were found in German personnel. Contradictory findings are given regarding the position of Belgian respondents on this dimension.

Finally, on other work related attitudes and experiences only some tendencies could be noted. Comparatively, Belgian employees in general seem to be most critical on their job and employer. In particular physical working conditions and "work pressure" are felt to be less satisfactory in Belgian and German firms compared to those employed in Dutch firms.

\subsection{Summary}

Chapter 10 focussed on three societal conditions and their (alledged) role visà-vis cross-national sickness absence differences, namely social security elements, epidemiological aspects, and work-related values and attitudes.

Sickness benefit arrangements and procedures seem to affect the variations in incidence and duration of absences in our countries considerably. High numbers of short term absences in the Dutch group will to a large extent be due to the uncomplicated way of notifying work incapacity in this system. Long term sickness absence in this country is further conditioned by full income replacement during sickness, restricted regulations of patient-doctor contacts (both in the curative and insurance sector), and by comparatively relaxed conditions to qualify for invalidity pension receipt (regarding minimum degree of disablement required, contribution periods, etc.).

The comparison of invalidity incidence rates indicated that in the Netherlands yearly about twice as many invalidity pensions are being awarded than under Belgian and German regulations (age-standardized). Especially regarding two major diagnostic groups considerable higher rates were noted in the Netherlands, namely on "mental disorders" and "muscoskeletal diseases". How far epidemiological, socio-cultural aspects or disablement assessment methods account for these difference could only be partly considered. Mortality rates were higher in Belgian and German recipients of disablement benefits than in Dutch beneficiaries. This finding globally suggests a somewhat healthier status for Dutch recipients, or a different pattern of (non-lethal) health complaints and disorders. The comparatively high attraction of invalidity pensions for leaving the labour market may also be attributed to the lack of statutory early retirement arrangements in this country.

Comparisons of some classic health status indicators consistently showed (agestandardized) mortality rates being lower in the Netherlands and higher in Belgium and Germany. Also on life expectancies more favourable prospects were noted for the Dutch. Some characteristics of health behaviour also suggested a somewhat healthier life style in the Netherlands. Dutch inhabitants showed considerably lower consumption rates for physician consultations and consumption of pharmaceuticals than both their neighbours.

Finally an attempt was made to compare selected socio-cultural aspects, namely work-related attitudes. Unanimous conclusions from available studies are quite rare. Our sources provide similar conclusions regarding only two factors, the weight attributed to non-financial aspects of jobs and job satisfaction. Dutch employees seem to be less critical of pay and benefits and 
more attached to non-material aspects of work (e.g. working relations, organizational climate). Furthermore German employees showed lowest ratings on satisfaction regarding job and firms and Dutch highest. Finally the tendency was found that attitudes and value orientations in Belgian employees show a considerable contrast with preferences found in German and Dutch employees, which generally showed several similarities. The interpretation of this variety of societal differences will be a main issue of our final chapter. 


\section{NOTES}

(1) Whereas in 1978 still 31.6 work incapacited were examined per 1000 spells in 1984 still 24.3 persons were medically evaluated (Münstermann, 1987).

(2) Derived from data on completed spells by major diagnostic groups in: Centraal Bureau voor de Statistiek, Statistiek Omslagleden. Poelstra et al. (1985) showed however considerable variations between occupational associations regarding the proportion of spells being medically evaluated (cf. Table III).

(3) Where possible rates were further matched as to population covered (excluding miners from Belgian and German rates; also occasionally excluding voluntarily and latent insured and insured over 64 years in the German population of insured). In the end Belgian and Dutch rates showed to be highly comparable. In German rates major sources of bias could not always sufficiently be accounted for.

(4) The bias introduced this way may be small as about only $15 \%$ of DSA-benefit recipients fall into lower disablement classes (up to 55\% disablement). Finally it should be remembered that Dutch rates may be somewhat higher due to the inclusion of occupational injuries and diseases.

(5) Rijksinstituut voor Ziekte- en Invaliditeitsverzekering, Dienstjaar 1987, Table 9. German rates were derived from: Bundesminister für Arbeit und Sozialordnung (1988a). These figures also include recipients aged over 64 , which are not covered under the Belgian and Dutch scheme. Annual reports from the Gemeenschappelijke Medische Dienst (1969...1988) provided data for the calculation of Dutch rates.

(6) Belgian rates were calculated from tables on entrants (by age group, sex and occupational status) and insured (by age group, sex and occupational status) provided by the Rijksinstituut voor Ziekte- en Invaliditeitsverzekering, Brussels. German rates were derived and adapted from tables T1 and T8 in the yearly governmental reports on the Pension Insurance (Bundesminister, 1980...1986b). Annual reports from the Gemeenschappelijke Medische Dienst provided data for the calculation of Dutch rates. (Gemeenschappelijke Medische Dienst, 1980...1987).

(7) Our Belgian estimate was based on personal information from Mrs. De Boeck, Rijksinstituut voor Ziekte- en Invaliditeitsverzekering, Brussels. German sources were found in: Bundesminister, 1980...1987b (Table T3). Dutch acceptation rates were derived from Gemeenschappelijke Medische Dienst, 1980...1987 (Tables on assessed degree of invalidity).

(8) In all programme administrations the 1980 International Classification of Diseases, Injuries and Causes of Death (ICD) is applied. Belgian overviews were provided by the Rijksinstituut voor Ziekte- en Invaliditeitsverzekering, whereas the Dutch Gemeenschappelijke Medische Dienst annually publishes similar tables of new DSA-recipients by main diagnostic categories. For the German system data were derived and adapted from: Verband Deutscher Rentenversicherungsträger (1983...1987a), Table 57 RVZ, Pflichtversicherte.

(9) Belgian rates originate from overviews (on "Entrants" and "Leavers") provided by the Rijksinstituut voor Ziekte- en Invaliditeitsverzekering. German ratio's were calculated from governmental annual reports on pension insurance (Table T5), whereas Tables on "New beneficiaries" and "Terminations" from the Gemeenschappelijke Medische Dienst provided basic data for the Netherlands. These data however are not limited to wageearners and salaried employees but also cover self-employed and early handicapped (comprising about $16 \%$ of the entire population of recipients).

(10) Belgian and Dutch rates could easily be calculated from overviews provided or published on invalidity pension recipients and terminations. German rates were calculated and provided by the Verband Deutscher Rentenversicherungsträger, Frankfurt.

(11) Alcohol consumption rates were derived from Casselman \& Knibbe (1985) and information from the Centraal Gedestilleerd Bureau, 1986. Information on traffic accidents were calculated from Bureau van de Statistiek der Europese Gemeenschap (1988a). Medical consumption rates were derived from the Organization for Economic Cooperation and Development, 1987; Sichrorsky, 1984 and Nefarma, 1986. 
(12) E.g. consultation rates are not standardized to age, whereas expenditures also are affected by pricing policies in countries. 


\section{CONCLUSIONS AND INTERPRETATION}

\subsection{Review of research goal and study background}

In debates on sickness absence it has often been argued that Dutch rates are higher than those in other West European countries. Indeed, some crude data indicated unanimously that employees in the Netherlands and Sweden show comparatively the highest sickness absence rates compared with employees in other industrialised countries. The present study of sickness absence in the Netherlands and its neighbouring countries intended to avoid so far as possible the methodological and statistical constraints connected with most earlier publications. The first goal of the study was nothing more than an orientation to ascertain whether or not our problem was imaginary. Accounting for conceptual, administrative, and statistical factors the investigation aimed to explore differences in the level and structure of sickness absence in our countries under study. The second objective of this investigation was to assess the factors or processes that may account for observed cross-national differences.

In this chapter the results of the various inquiries carried out within our project will be taken together and discussed. The magnitude and structure of cross-national sickness absence differences will be considered in Section 11.2. Next our attention will be focussed on the "explanations" which, with more or less empirical support, can be given for the divergent sickness absence levels observed. Conclusions from separate inquiries carried out will be integrated and compared with earlier findings or statements (Section 11.3). Further it will be asked whether the salient position of sickness absence behaviour and its social security context may be related to socio-cultural aspects like views and value orientations, vis-à-vis work and health in the Netherlands. Finally, we will discuss some consequences of a relatively high sickness absence level and indicate some aspects of our subject that need further attention (Section 11.5).

\subsection{Magnitude and structure of cross-national differences}

In order to interpret our conclusions major findings on cross-national differences will now be summarized. Firstly, the conclusion can be drawn that earlier studies with a weaker methodology rightly indicated the position of our countries on the international sickness absence rank order. Standardized data indicated the lowest level of sickness absence was found among the Belgian group, whereas the Dutch group showed the highest rates both in severity and frequency. German employees took a middle rank on both absence measures. In more detail our inquiry made clear that short term sickness absence (lasting 1-7 days) was substantially more frequently observed in the Dutch group than in both other groups. Within the second duration group discerned (spells lasting $8-42$ days) both the German and Dutch groups showed nearly twice as 
many spells of sickness absence as their Belgian counterpart. Severity rates differed in an identical way. The three groups showed overwhelmingly divergent frequency and severity rates of long term sickness absence (lasting 43-365 days). The Dutch group had about $100 \%$ more spells lasting over six weeks than the comparable Belgian group (and German rates were exceeded by over $60 \%$ ). It has been concluded for each duration class highest rates were found in Dutch personnel and lowest in Belgian firms. But in particular the higher frequency of long term spells accounted for the roughly 100\% more days lost in Dutch employees.

Secondly, in the Dutch group absence taking behaviour may be typified by the presence of many "repeaters" and comparatively low percentages of "never sick". Our data indicate taking a spell of sickness absence is a more widespread sort of health or work-oriented behaviour in Dutch firms than in foreign organizations. Finally, the weight of long term spells in Dutch sickness absence was shown to be not only due to a relatively slow work resumption in case of serious disorders or complaints. Also the comparatively high number of spells reaching the 52nd week, which "qualifies" for invalidity pension, showed to account substantially for the higher percentages of days lost in Dutch firms.

Several conditions contributed to a satisfactory validity of these findings. As indicated a controlled comparison was made within four clusters of firms matched to some relevant characteristics. We realise the populations examined in this study will not accurately represent the entire population of Belgian, German, and Dutch employees. But the following points should also be noted. The international differences in sickness rates in our clusters and for both years are large and consistent (after applying standardization). Moreover we recorded and calculated the data in a uniform way which strongly reduced measurement biases. The only cross-national investigation carried out during our project and also considerably allowing for some "data restrictions", highly confirms our conclusions. In their investigation based on adapted sickness benefits administration data Pfaff et al. (1986) reported strikingly resembling conclusions on the top position of Dutch sickness absence levels. Age- and sex-standardized severity rates for 1979 showed for the Dutch insured about $60 \%$ more days lost and five times more spells lasting 52 weeks than in the comparable German population (Belgium had not been included).

According to our trend analysis of benefits-related data in each country absence rates decreased after 1980. The expectation that our rank order still holds was supported by a comparison of recent sickness absence figures from our countries under study by combining Pfaff's approach with estimates from our inquiry. For 1987 estimated sickness absence percentages for Belgian, German and Dutch insured were 3.4, 5.1 and 7.9, respectively (standardized for age and sex). Moreover, compared to the Belgian and German insured, consistently still about twice as many spells lasting over six weeks could be observed in the Dutch population. In 1987 for the Dutch population still three times as many spells were reaching the 52nd week than in neighbouring insured. The relatively high level of sickness absence, with comparably heavy weight of long term work incapacity, seems to be a quite stable characteristic of the Dutch situation. 


\subsection{Interpretations of sickness absence differences}

Both the choice of our research design and the outcomes of the statistical analysis in our cross-organizational comparison allow us now to start with an exclusion of some - often heard - explanations. Firstly, in this inquiry sickness absence cannot be ascribed to a lack of equivalence of concepts and measurements. A second source of variation could also be controlled for. Effects of major sociodemographic characteristics, as age, sex, nationality and being migrant or native, have been compared and shown to be highly similar. By standardization and multivariate analysis their bias of cross-national differences has been corrected. In a crude way, thirdly, the effects of work type and working conditions could be accounted for. Not only by selecting firms with similar types of product and production process, but also in our analysis of work related variables (occupational status, shift work, etc.) this category of factors was shown not to affect cross-national differences seriously. Additionally, it may be noted, however, that cross-national employee surveys generally noted more complaints on working conditions and job stress in Belgian employees than in German and Dutch employees (Hofstede, 1980; Harding et al., 1986; International, 1987).

A fourth approach did not provide a satisfactory explanation either. Vroege (1982) found a strong association of national sickness absence rates to number of days off, suggesting highest Dutch absence rates originated from an incorrect balance of work load and work capacity. Disregarding methodological weaknesses in his original data used, our comparisons showed fairly identical numbers of days off for firms with highest or lowest absence rates. Moreover, due to working time reduction arrangements considerably more time off may be noted nowadays in Dutch industry compared with German and, in particular, Belgian firms. In 1987 employees in the Dutch industrial sector had 36.5 days off (including public holidays: 42.5); for German and Belgian industrial workers 30 (40) and 25 (36) were noted, respectively (Institut der Deutschen Wirtschaft, 1989).

Our analysis in Chapter 8 and 9 supported the view that factors underlying cross-national sickness absence differences predominantly have to be sited and explored on a national level. In the limited cross-organizational comparison only a few differences were found, namely regarding employment policies, occupational health care and sickness absence strategies. So we will have to concentrate now on those system-bound factors and conditions, which by definition, apply to all (employed) persons and which could or are known to differ between our countries under study. Our search for explanations concentrated on three clusters of factors, namely social security regulations, health conditions, and socio-cultural variations. It became quite clear that empirical evidence on this macro-level to support explanations is often poor, and intervening factors or interactions hardly can be controlled for. Sometimes it will largely be left up to the reader to accept or reject our interpretation.

The relationships of macro-level factors to cross-national differences will be considered for four stages in the micro-process of sickness absence behaviour (cf. Chapter 7). Our countries will subsequently be compared regarding the role of differences in health status and in the adoption of the sick role (Section 11.3.1), factors known or assumed to affect the act of reporting sick (Section 
11.3.2) as well as determinants of spell duration and mode of terminating sickness absence (Section 11.3.3).

\subsubsection{The role of morbidity}

Taking a spell of sickness absence legally and socially presupposes a (temporary) health reduction and adequate illness behaviour which prevents a person from attending work. Therefore, the inverse relationship found between health indicators and sickness absence rates on nation-level may be surprising. Classic health measures (life expectancies, mortality rates) however, do not validly reflect differences in non-lethal diseases and disorders (e.g. psychosomatic syndromes and chronic-degenerative diseases). Indeed some of our invalidity pension data suggested mental disorders and muscoskeletal diseases to be more prevalent in Dutch employed. However, differences in eligibility criteria, health beliefs (defining psychosomatic complaint as disease) and medical evaluation methods seriously restrict the cross-national epidemiological validity of such data.

It should be noted that in each population of employed persons a certain supply of health problems and complaints can be found. It may depend considerably on country-bound values and standards of patients and the medical profession whether certain ailments, complaints or health problems are being labelled as sickness and, consequently, treated. Payer (1989) noted several cultural biases in the ways of looking at and treating illness, in Britain, the U.S.A., France and Germany. E.g., according to German diagnostic rules for $40 \%$ of some population an abnormal ECG was found whereas only $5 \%$ were found to be abnormal according to American criteria. In the USA and England low blood pressure would only be considered as unpleasant, but in the German concern over health (cf. Table 10.4) it is considered and treated as a disease. The author indicates such contrasts may originate from differences in national values and views on the human body. Cross-national information covering Dutch patients, medical professions and their health-related values and beliefs is very poor. A recent investigation, which was only including "reported health status", showed comparatively more favourable rates in Belgian and Dutch respondents than in German respondents (Stoetzel, 1983). So far we may only conclude most sources reflect the relative top position of the Dutch on various health status indicators.

\subsubsection{Reporting sick}

Societal factors (benefit procedures, perceived job security, sick role expectations) and company strategies will also effect the selection of health problems for which the worker will report sick and adopt the dependent patient role. An often cited but poorly studied report on a preventive investigation in over 30.000 male Germans in the early 70 's illustrates the important role of the absence tolerance threshold. In about $64 \%$ of males normally attending work a disease or disorder was diagnosed which needed treatment by a general practitioner or specialist (Arbeits- und Sozialministerium Baden-Württemberg, 1971). More recent sources also indicated the wide gap between (temporal) health problems and reporting sick. According to the "Mikrozensus" 1982 only 
$25 \%$ of the employed who referred to bad health actually had stopped working (Kern, 1984). But Dutch sources also indicate that absence from work due to sickness underestimates the number of persons which report a temporary poor health status. In a nation-wide panel-study about $27 \%$ of employed respondents reported poor health whereas at the same time approximately only $9 \%$ of workers had reported sick according to sickness absence statistics (Van der Horst, 1988). The discrepancy between sick role and dependent patient role seems to be the smallest under Dutch circumstances.

Which factors facilitate reporting sick for Dutch personnel, and restrict absence taking in our other populations, with in general an even poorer health status? Our investigation demonstrated some differences between our countries in the income maintenance arrangements, executive procedures and related company strategies which have to be taken into account. Outcomes have been set out in Table 11.1 and - for readibility - formulated as presence or absence of frequency reducing factors.

Table 11.1 Overview of frequency reducing factors in Belgium, Germany and the Netherlands

\begin{tabular}{llll}
\hline Factors & $\mathrm{B}$ & $\mathrm{G}$ & $\mathrm{N}$ \\
\hline Application of disciplinary measures & yes & yes & ? \\
Administrative barriers (certification) & yes & yes & no \\
Financial barrier (waiting days) & yes & no & no \\
Extended supervision procedures applied & $?$ & $?$ \\
\hline
\end{tabular}

In Belgian and German labour relations disciplinary actions seem to be applied more often (oral, written warnings), whereas job protection legislation also provides the employer here with a relatively easier applicable dismissal. Although the effect of certification is often considered arbitrary(1) the procedures give both employer and employee information on the (alleged) length of absence from work. Under Dutch regulations reporting sick may become a more anonymous action, and at the onset both employer and employee do not know the probable duration (neither does the fund). Most relevant however is the observation that the factors depicted in Table 11.1 are concentrated in the Belgian situation and almost lacking under Dutch circumstances. Contrary to the narrow Belgian work incapacity concept (over $662 / 3 \%$ loss of earning capacity) in the Dutch context a broad concept is applied, leaving room for personal interpretation and freedom of decision. Consequently reporting sick with minor ailments or psychosomatic complaints meets hardly any barriers in the Netherlands. Temporary withdrawal from work to cope with work and life stress seems to be socially more accepted here than in Belgian and German situations. Finally, it should also be mentioned that, insofar as reporting sick can be seen as strategic employee action (Henderickx, 1985), opportunities are also more favourable in the Netherlands than elsewhere. In certain sectors with labour conflicts incidental actions to report sick collectively may support this hypothesis (e.g. policemen, airport employees, firemen). Maybe the relatively high job satisfaction rates in Dutch workers should also be attributed to this condition (cf. Section 11.5).

The outcomes of the decision process to report sick or not, given a certain 
health deterioration, systematically differ between Belgian, German and Dutch employees. Consequently, the proportion of "sick attenders" ("zieke doorwerkers", "Krankheitsverschleppung") will also differ across nations. In the light of observed incongruities in health status and absence indicators this category of employees may be assumed to be considerably larger in the Belgian and German working populations than in Dutch personnel with a comparable lower absence threshold.

\subsubsection{Duration determinants depicted}

A range of factors in the province of social security and job protection, which affect the duration of sickness absence, differed systematically between our countries under study (cf. Table 11.2).

Table 11.2 Overview of major absence duration factors in Belgium, Germany and the Netherlands

\begin{tabular}{llll}
\hline Factors & $\mathrm{B}$ & $\mathrm{G}$ & $\mathrm{N}$ \\
\hline DURATION REDUCING FACTORS & & & \\
Firm-patient contacts & yes & no & yes \\
(Temporal) job adaptation & $?$ & no & $?$ \\
Strict work incapacity concept & yes & no & no \\
Income reduction & yes & no & no \\
Medical & yes & no & $?$ \\
Early retirement & yes & yes & no \\
DURATION PROLONGING FACTORS & & & \\
Eligibility criteria invalidity & no & no & yes \\
pension programmeSeparation of treatment and evaluation & no & no & yes \\
Waiting periods (in health care) & no & no & yes \\
\hline
\end{tabular}

Within the category of duration reducing factors the combination of income loss, a strict work incapacity definition and assessment methods will probably have a major influence on Belgian severity rates. Although for the majority of German employees longer lasting work incapacity does not imply financial consequences, a major difference with the Dutch workers lies in the qualifying criteria for invalidity pension payment. Whereas in the Dutch scheme prolonging sickness absence up to one year may almost automatically qualify for invalidity pension receipt, in the German programme other eligibility criteria are applied which do not take work incapacity duration into account.

Regarding the sickness absence inducing effects of the Dutch invalidity pension scheme it is meanwhile widely accepted that reduction or renewing of work forces has also been reached by stimulating the influx in the disablement pension programme. Firms have used this programme to promote early exit without being too costly to the employer.(2) Leaving the work force and labour market this way is socially more acceptable, rather easily arranged and for the employee financially more favourable than dismissals and lay offs.

This, however, does not mean that Dutch disability benificiaries would not experience a deterioration of health. In several inquiries significant higher mortality rates and a poorer health status have been found in disability pension recipients compared to employed, early retired or unemployed persons 
(e.g. Philipsen \& Halfens, 1983; Groothoff, 1986, Van der Horst, 1988). In the Dutch situation the absence of a financial need to return to work, however, does not imply that these conditions guarantee optimal treatment and recovery. Several investigations showed the process of being work incapacitated is often sustained by the medicalisation of personal and work-related problems. Also health care facilities (waiting periods) and the organization of medical evaluation or counselling of the insured was shown to create "iatrogenic" sickness absence in this country. The separation of treatment and (work incapacity) evaluation resulted in little involvement of the curative sector with long-term work incapacity, mere voluntary doctor-patient contacts, coordination problems and a poor communication with the social insurance sector. An earlier cross-national inquiry indicated that such problems are negligible in many other countries (Andriessen et al., 1983). Primary and follow-up certification of work incapacity requires regular contacts between patient and physician, and also in many countries claims for invalidity pension have to be initiated or supported by the attendant physician. Their role in sickness benefit and invalidity claim procedures is not considered controversial and is understood as self evident for a smooth processing of their patients income maintenance claim.

It also came out that, due to mainly more rigid eligibility criteria, the "supply" of long-term work incapacitated is smaller in neighbouring countries. Consequently this can be dealt with more accurately by the social security apparatus. In addition, a more widespread supply of health care may also contribute to less waiting periods and, consequently, to the lower number of long term sick and higher work resumption speed in this country. Groenewegen \& Leroy (1985) compared some supply side factors (1983) and found a higher density of general physicians and specialists (but also less hospital beds) in Belgium, compared with the Netherlands. Without additional research, however, these relationships will remain unclear. Finally, a limited sickness absence-reducing effect may be assumed from the wider range of early retirement options in Belgium and Germany. These provisions allow older employees with deteriorated health to leave the labour force without having to meet invalidity programme criteria.

\subsection{Cross-cultural aspects of sickness absence differences}

Now the question may be raised why the social security, employment and health (care) situation of Dutch employees differs in various respects from Belgian and German conditions. These variations may probably be better understood by relating them to underlying variations in national cultures. Starting from Hofstede's conclusions (and their reflection in Stoetzel's study) we noted the Belgian culture being characterized by a high degree of "power distance" and "uncertainty avoidance" (cf. Section 7.5). In contrast, the Netherlands and Germany were merely typified by lower positions on these dimensions. Minor differences were noted vis-à-vis the high degree of "individualism" in national cultures. But the preference in Dutch value systems for modesty, relationships and caring for the weak is in striking contrast to the competition and material success oriented values in the more "masculine" Belgian and German culture. The comparatively high degree of "power distance" in Belgian culture may be 
reflected in the acceptance of considerable inequality we noted in Belgian labour relations. In this country, the employer has the widest range of flexible employment methods, without compulsory permission of governmental or workers council representatives (as in Germany or the Netherlands). The desirability of inequality is further illustrated by the occupational status differences between manual workers and staff employees (e.g. regarding protection against dismissal, continued wage payment during the first weeks of work incapacity). These differences have been reduced and almost diminished in the German and Dutch situation, respectively.

According to its emphasis on "uncertainty avoidance" Belgian culture would also have to show a greater need for legislation and regulation than both other countries. This cultural dimension now can be understood to underlie several issues we discussed, e.g.:

- the prescription of a waiting day, to ensure the prevention of unnecessary absence;

- the compulsory certification of all spells of work incapacity;

- the strong belief in expert knowledge in the evaluation of work incapacity. In the Netherlands, with lowest priority given to this dimension, lay personnel do the first check. In both other countries only medical expertise may legally fulfill this task. As we noted only in the Belgian situation do double assessment practises exist, namely by sick fund and private doctors, the latter operating on behalf of the employer.

The comparatively low preference to uncertainty avoidance in the Dutch value system is also illustrated by the abolition of separate sickness and accident benefit arrangements. In both other countries this division in health risks leads to double administrations, each with its own judicial context and regulations, and further in each sector an alertness to prevent claims that should be adressed to the other sector. A content analysis would almost certainly show, that Belgian and German articles on work incapacity contain a much higher percentage of judicial and administrative issues than in the Netherlands.

Finally, the low score of the Netherlands on the "masculinity" index has also been reflected in some outcomes of this inquiry. Both the highly developped income maintenance programmes as well as a considerable job security in this country may originate from norms on quality of life and sympathy for the unfortunate. Also the role perceptions of insurance doctors seem to reflect a well-being-oriented attitude in Dutch society. Not only the relatively high acceptance rates of mental disorders for invalidity pension eligibility reflect a broad concept of health. Also the attempts at integrating patient counselling with work incapacity evaluation in the job of the insurance doctor would be considered as contradictory in many other countries, where the medical profession seems to have more authoritarian attributes (Payer, 1989).

The introduction of some dimensions of the cultural context of our countries in our inquiry indicated the differences observed in several sectors (social security, health behaviour, company strategies), are not to be seen as isolated or random phenomena. They are highly connected to some prevailing norms and value orientations in our countries under study. This condition may also make us aware of an important restriction of the utilization of comparative investigations. Due to their historically developed links with underlying 
cultural traits a "transplantation" of attractive elements in social security or company policy in one country to another may become rather complicated and less fruitful than their operation in the original context.

\subsection{Consequences and conclusions}

In our analytical model a sequence of events and decisions was depicted that was assumed to underlie sickness absence behaviour. Several conglomerates of factors were discerned and subsequently explored in regard to their meaning for cross-national sickness absence differences. Several findings attributed to our explanation of divergent sickness absence rates. Firstly, we noted that the supply of health complaints and disorders in a (working) population to some extent may differ according to culture-bound health beliefs and illness concepts in patients and doctors. It was indicated the sick role is least prevalent in the Dutch population. Secondly, legitimation procedures, company strategies and norms may function as a filter for taking absences. Due to these factors under Belgian and German circumstances a smaller proportion of the sick will adopt the dependent patient role than in Dutch workers, who are confronted with less extended barriers to report sick.

Thirdly, once having adopted the dependent patient role Belgian employees are confronted with most incentives to return to work. Medical supervision, by a general or insurance doctor (or both), income reduction, and limited job security may in due course counteract the prolongation of sickness absence. Medical experts tending to counselling, and less discipline-oriented employer reactions seem to characterize the Dutch version of the dependent patient role. We noted a relatively high proportion of transfers to disablement pension in Dutch exit patterns. It was indicated that social security factors and company conditions considerably contribute to the high rates for long-term sickness absence and disability in the Netherlands.

Sofar we focussed on sickness absence as the dependent variable of our inquiry. As high absence rates may have some latent or manifest functions, also some light should be thrown on the effects of higher absence rates in the Netherlands. Considering sickness absence now as an independent variable we will consider five conclusions and suggestions.

Firstly, variations in sickness absence and invalidity rates obviously will produce differences in personnel costs, like payroll expenditures or benefits programme contributions. Direct comparisons of international figures on the financing of systems are complicated, due to system differences. For our threecountry comparison, however, an attempt could be made.(3) In our highly comparable firms we found that the Belgian employers on average had to pay normal wages for $78 \%$ of all absences, covering about $23 \%$ of all days lost (1980-1981). Due to legal wage payment continuation $94 \%$ of absences and $62 \%$ of all days lost were paid by the German employer in those years. Consequently, employers contributions in sickness benefit arrangements are very low: for 1988 the Belgian employers contribution for sickness insurance benefits was $2.2 \%$. Estimates for German employers indicate that in the entire employer contribution (6.5\%) only $6.1 \%$ may be considered as covering benefits (Krankengeld). Hence, German employers contributed about $0.4 \%$ of 
gross earnings for sickness benefits insurance (1988). It may be concluded differences with the Dutch system are striking. Almost every employer pays a fixed percentage (in 1988: the national average was $4.8 \%$ ), related to the risklevel in their sector.(4)

Secondly, our investigation supports the suggestion that eligibility criteria and general health behaviour may have a reducing effect on health care expenditures in the Netherlands. Absence of compulsory certification limits the number of consultations and, consequently, the prescription and consumption of pharmaceuticals.

Thirdly, Dutch arrangements in case of sickness and company strategies may allow full recovery without fear of increased risk of job loss. It is tempting to assume that this potentially health promoting condition will also account for the observed higher life expectancies and lower mortality rates in this country. Fourtbly, labour relations are considered to be quite harmonious in the Netherlands. Historically, the number of days lost due to strikes and labour disputes is comparatively low. But more recently cross-national differences seem to have decreased. Notwithstanding, from 1980-1987 in Germany 35 hours were lost due to strikes (per 1000 employees), whereas in the Netherlands only 18 hours were noted (Belgian data are lacking)(Institut der Deutschen Wirtschaft, 1989). We already noted Dutch conditions provide more opportunities for individual or collective strategic action. In case of conflicts, complaints or poor motivation temporary withdrawal from work is easier to realize than in our neighbour countries. Maybe this larger degree of freedom and the high invalidity incidence related work force selection processes also explain some of the comparatively high job satisfaction scores noted in Dutch employees.(5)

Finally, criteria and contents of Dutch sickness benefit arrangements require an extended executive organization of medical evaluators and non-medical inspectors. Consequently, programme administration expenditures may be assumed to be larger than abroad. A crude comparison indicates that for the evaluation and monitoring of temporary work incapacity per 100.000 insured in the Netherlands about 12 social insurance doctors are available (1984) whereas for the Belgian and German scheme only 6 and 5 physicians suffice, respectively. (6)

Vis-à-vis labour market conditions our overview of major consequences of high sickness absence rates suggests the operation of a substitution process. Regarding disadvantaged categories of workers (un-skilled or semi-skilled with deteriorated health and productivity), high sickness and invalidity rates in one country may partly be substituted by a higher utilization of early retirement or unemployment schemes in an other country. (7) Within a wider social security context a similar pattern of interdependencies can be assumed. Whereas in one country with a certain "supply" of health problems a considerable burden may arise from expenditures of income replacement programmes, in another country lower absence rates but a poorer general health status and relatively higher health care expenditures are being noted.

Reviewing our results we may note that some elements or processes need more thorough attention. The introduction of own-risk elements in Dutch sickness benefit arrangements may affect employers awareness and employee 
attendance behaviour. However, as main differences in sickness absence levels are lying in medium and long-term sickness absence, the work incapacity process and its legal and administrative context need more concern. The fixed one-year waiting period before entry into the invalidity scheme intrinsically shows a duration-increasing effect, which may be limited by introducing a flexible claim evaluation moment. But also differences in the position, expertise and evaluation techniques of social insurance experts in the three countries under study may need more clarification. Moreover, the low termination rates of young disabled evoke questions on policy and practices of administrating bodies, as well as rehabilitation policies in the Netherlands. In spite of these macro-level aspects work-related measures should not be excluded. A wider availability of occupational health care in the Netherlands may contribute to more actions being taken in an earlier stage of the work incapacity process in high risk groups (e.g. health surveillance of the older, unskilled or semi-skilled worker). The interdependency of labour force exit patterns should also be taken into account, however. Without additional labour demand a reduction of sickness absence and declining numbers of disability recipients would certainly be accompanied by comparatively higher unemployment rates. 


\section{NOTES}

(1) In the U.K. five years ago compulsory certification was abolished for sickness absence lasting up to one week. The incidence of absences as well as severity rates did not show a substantial increase afterwards (personal communication from Dr. Searle, Birmingham). Further, it may be assumed that effects of certification are conditioned by prevailing type of employer absence strategies (more or less disciplinary).

(2) The president of a large employers organization declares in an interview: "I do acknowledge that many employers wrongly used the Disability Security Act. I did it myself too. It was an ideal provision to get rid of someone. The DSA provided an opportunity if dismissal was difficult. I also think that in the medical evaluation someone is very easily declared unfit" (Ondernemers, 1989).

(3) Belgian and German rates (estimates) were based on: Institut der Deutschen Wirtschaft (1989), and additional information from the Rijksinstituut voor Ziekte- en Invaliditeitsverzekering, Brussels, and the Bundesministerium für Arbeit und Sozialordnung, Bonn.

(4) Employee contributions amounted to 1.15 (Belgian), 0.4 (German) and 1\% (Dutch) of gross earnings.

(5) Dutch employees recently took a third rank on an international rankorder based on employee attributes (motivation, skill, days lost due to strikes, absence, etc). German and Belgian workers occupied the fifth and seventh position, respectivily (Noten, 1989)

(6) The Dutch estimate regards the majority of occupational associations (GAK) and has been calculated from Poelstra et al. (1985) Table III p. 111 and from information on number of insured in: Sociale Verzekeringsraad (1985) Münstermann, (1989) and Bundesminister... (1988) pp. 174 provided comparable data on physicians and number of insured for the FRG. Belgian rates were calculated from information on number of physicians (personal communication from Mrs. De Boeck, Rijksinstituut voor Ziekte- en Invaliditeitsverzekering) and Rijksinstituut, 1988.

(7) Geerts (1976) suggested in economic growth periods 2/3 of Belgian unemployed are more or less handicapped. In Germany persons with deteriorated health may be covered by a social assistance and rehabilitation programme for severity disabled ("Schwerbehinderte") which covers the entire population. Labour statistics indicate about $20 \%$ of German unemployed reported health restrictions (1987) whereas 6\% occupied the severity disabled status (Oldiges, 1984; Rindt, 1988: Bundesminister, 1988a) 


\section{SUMMARY}

The magnitude and trends of sickness absence in the Netherlands and their economic and socio-medical consequences attracted serious attention from decision makers and investigators. Not surprisingly often questions have been risen on the developments in other West European industrial nations. Indeed some sources suggest Dutch sickness absence rates being one of the highest compared with other European countries. As available overviews often showed a restricted comparability this study attempts to obtain a more valid and thorough insight in the scale and nature of sickness absence in employees in the Netherlands and its neighbour countries. The central problem of our inquiry comprised two questions (Chapter 1):

1. Which differences may be observed between sickness absence rates of employees in Belgium, Germany and the Netherlands?

2. Which factors might account for these differences?

Preliminarily, sickness absence was defined as temporary health-connected absence from work, irrespective of the actual causes (illness, injury, confinement). The present investigation comprises three steps of inquiry. To get acquainted with the subject it was decided to explore firstly previous studies and available statistics on the subject as well as its institutional context in each country (PART 1 PREPARATORY STUDY). In the second part (A COMPARATIVE ANALYSIS) the magnitude and nature of cross-national differences in sickness absence rates will be analysed, whereas in the final part (INTERPRETATIONS) potential backgrounds of observed differences will be explored.

In order to obtain some insight in the specific problems of cross-national investigation into our subject in the second chapter some previous inquiries were considered. The 13 studies examined, covering a period of over 20 years, fall into two categories. Most common are macroscopic inquiries, based on aggregated data from populations of employed persons, insured, etc. Mesoscopic studies, comprising the second category, used data from a limited number of comparable firms. However, it was concluded that methodological weaknesses of data have not always been taken into account. Unequal concepts and measures, dissimilar populations, data incongruities and restricted validity of interpretations were found to be major pitfalls. Mesoscopic studies showed least methodological restrictions and the most favourable research opportunities, their external validity (e.g. representativeness) being restricted, however. Disregarding their limitations most studies were quite unanimous: Dutch sickness absence rates were mostly found in the upper region of the international sickness absence rank. 
Chapter 3 explored the legal and institutional context of sickness absence in each country. Considerable differences were noted in structure, executive procedures and benefits level of temporary work incapacity regulations. In contrast to both other schemes under Dutch regulations both sickness and injury are covered by the same income maintenance programme and are paid for equally. In no country has the concept of work incapacity due to sickness been operationally defined. Consequently in Belgian and German regulations medical certification by an attendant physician is obligatory. But in the Netherlands work incapacity is not being assessed at the onset but after one or a few days, by lay inspectors and insurance doctors. Sickness absence has more direct financial consequences for Belgian and German employers than for their Dutch colleagues, since the former have to continue normal payment of full wage during the first weeks. After some weeks, Belgian, and to a less extend German employees experience financial consequences of sickness absence as well. Under the Belgian programme after 2-4 weeks work incapacity may cause a $20 \%$ net reduction of income. Consequently, a worker who falls ill or becomes victim of an injury finds himself in a social security context which is most favourable in the Dutch situation and least attractive under Belgian arrangements.

In Part 2 firstly the conclusion was drawn that conceptual, administrative and statistical sources of bias would be better accounted for by using individual data from selected firms (Chapter 4). This level of analysis could provide the opportunity to ensure a standard definition and measurement of sickness absence whereas major confounding factors (population characteristics) could also be appropriately controlled for. The research plan developed primarily focussed on a controlled comparison within a multiple case design. In each country some organizations were selected that were matched on the basis of their product and type of technology, company size and geographical location (urban or agricultural region). By matching the organizations this way, resemblances were considered to be "ruled out" as explanatory factors.

Four international clusters of similar firms could be formed which produced paints/coatings, margarine, frozen foods, tins/cans, respectively. As one German factory withdrew, finally a total of 11 organizations participated in our inquiry. Our definition and measurements of sickness absence included work incapacity due to illness, injury, confinement or maternity leave, irrespective of whether medically attested or not (with a maximum spell duration of one calendar year). Sickness absence data and ten population characteristics were collected by hand or computer tape and covered 11.127 employees (observation period 1.1.1980-1.1.1982).

Chapter 5 gives a full report of the case studies carried out in our four clusters. In the analysis three basic sickness absence rates were used, referring to the severity (sickness absence percentage), frequency and duration of absences. In all clusters the same comparative strategy has been applied. Simple comparisons indicated sickness absence to be a more severe problem in German and Dutch firms than in Belgian organizations. Direct standardization for sex, age and occupational status sharpened the differences observed before and produced findings which showed to be highly consistent over clusters and years. In 
all clusters the lowest level of sickness absence was found in Belgian firms, German employees took a middle rank and Dutch personnel showed highest sickness absence rates in three out of four clusters.

In Chapter 6 it was concluded our inquiry confirmed and enriched conclusions from methodologically weaker studies. Compared with their Belgian colleagues, working in similar firms and with the same population structure (as to age, sex, occupational status) Dutch employees yearly report $70 \%$ more sick and consequently about $90 \%$ more calendar days were lost. German employees showed an intermediate position between both groups. Regarding medium (1-6 weeks) and long-term spells (7-52 weeks) Dutch employees showed an excess of $100 \%$ compared to the Belgian population. In Dutch firms absence taking behaviour is further characterized by the presence of many "repeaters", a relatively small number of "never sick", and a relatively high frequency of (very) long lasting spells. On the contrary, among Belgian employees a relatively small proportion of persons reports sick and on average only once a year. Another major difference was found in the number of spells lasting up to 52 weeks. In the Dutch group two or three times as many persons with such long term work incapacity were found (per 1000 persons) as in the German and Belgian group, respectively.

Finally, an analysis of trends, based on social security data, showed quite similar developments in German, Belgian and Dutch rates from 1980 on (declining). The comparison of adapted and standardized benefits-related data over 1980 to 1987 further demonstrated highly consistent findings. Dutch insured in 1987 still reported about 50-100\% more sick than German and Belgian insured, whereas the incidence of long-term absences (lasting over six weeks) exceeded foreign rates by $80 \%$.

For the third part of our inquiry we firstly examined major investigations from our three countries to allow an insight in general and specific aspects of sickness absence. The conclusion could be drawn, that several factors and their relationships to sickness absence are common for employees in each country. This not only applies to socio-demographic factors (age, sex, nationality), but also to work-related aspects (labour relations, job content, supervisory methods, work stress). The findings and theoretical notions from these investigations have been integrated into a theoretical model of sickness absence. It was decided to apply a decision-theoretical approach for our further interpretations as it comprises both health related factors (objective and subjective state of health), social norms and perceptions (as to reporting sick), organizational factors as well as social security elements.

In our research design, however, attention would be focussed a limited number of relationships and clusters of factors. After having assessed the relationships of variables on lower levels to absence measures (individual and firm variables), factors operating on societal level will be considered. On this level firstly the operation and utilization of income maintenance programmes will be compared (sickness, invalidity, unemployment, early retirement). Secondly, some indications of health factors (health status, illness behaviour) and sociocultural aspects (e.g. job satisfaction) will be examined. 
In Chapter 8 the first step was made to identify potential person- or job-related determinants of sickness absence differences. A multivariate analysis (canonical analysis using alternating least squares) was applied to selected population characteristics (age, sex, nationality, turnover) and work-related factors (occupational status, length of service, shift work) to find out their relationships with sickness absence indicators. In general for our national groups the analysis showed a high agreement on statistical associations and risk groups discerned. A major difference regarded "turnover" (leaving the firm). In Belgian and German employees this variable was strongly correlated to taking many absences, which suggests the use of absence related selection processes. Analysing variables affecting the differences between national groups clearly showed strong effects of the factor "country" to our absence indicators. This unspecified heterogeneous term, covering socio-cultural, social security and health care elements, was the strongest determinant of national group differences in frequency and severity rates. The conclusion of earlier standardization has been supported that our selection of person and work-related variables may be excluded as explanatory factors for cross-national differences.

Our case studies in four clusters have been continued extensively in Chapter 9, where attention has been focussed on organizational aspects of sickness absence. Three main issues were selected to be compared across firms, namely their personnel policy (employment, working hours, attendance rules, etc.), working conditions and occupational health care, and sickness absence strategies (including the operation of benefit programmes). As research conditions were not similar in all firms that earlier had provided sickness absence data, only information from interviews with personnel managers and occupational physicians has been used. Taking account of their limited validity (social desirability risk) several similarities and some disparities could be demonstrated. Dutch personnel departments seem to show a less economic and more social orientated approach towards sickness absence compared with their Belgian and, especially, German colleagues. Furthermore, the Dutch occupational physician on average spends less time per 100 employees than both foreign colleagues. Dutch plant physicians spent considerable time on the supervision of sickness benefits claims and counselling of sick employees. The former task is not allowed and the latter seems less widely practised in firms from other countries. The relatively non-disciplinary orientated approach in Dutch firms may strongly be related to the 3-4 times higher incidence of persons terminating work due to disablement (after one year work incapacity). In Belgian and German firms "dismissal" may be used more often than by Dutch employers. In general the range of disciplinary measures to be applied (legally) seems to be widest in Belgian firms and most restricted in Dutch companies.

Chapter 10 focussed on some macro-level issues and their alleged role vis-àvis cross-national sickness absence differences. Sickness benefit arrangements, work incapacity criteria and medical supervision procedures seem to affect the incidence and duration of sickness absence in our countries. High numbers of short term absences in the Dutch group will largely be due to the uncomplicated way of notifying work incapacity in this system. Long term sickness absence in this country is further conditioned by higher job security, full income re- 
placement during sickness and by comparatively relaxed conditions to qualify for invalidity pension receipt. Social security data indicate in the Netherlands yearly about $100 \%$ more invalidity pensions are being awarded than under Belgian and German regulations (age and sex-standardized). Considerably higher rates were noted in the Netherlands for young and middle aged insured and extremely higher influx was found for "mental disorders" and "muscoskeletal diseases". Mortality rates were shown to be considerably lower than Belgian and German disablement benefits recipients. This finding globally suggests a somewhat healthier status for Dutch recipients, or a different pattern of (non-letal) health complaints and disorders.

For entire populations the lowest age-standardized mortality rates were found in the Netherlands, whereas on life expectancies also more favourable prospects can be noticed for the Dutch. Some characteristics of health and illness behaviour also suggest a somewhat healthier life style in the Netherlands (e.g. regarding risky habits) and considerably lower rates for physician consultations and consumption of pharmaceuticals. Finally vis-à-vis socio-cultural aspects only a few conclusions could be drawn. Dutch employees seem to be less critical on pay and benefits and more attached to non-material aspects of work (e.g. working relations). Regarding satisfaction with jobs and firms German and Belgian employees generally showed lower ratings than their Dutch colleagues.

In Chapter 11 the results of various inquiries carried out in our project have been taken together and discussed. Three major steps in the micro-model of sickness absence behavior were further discussed. It is concluded that sickness absence rates are poor morbidity indicators, and highest sickness absence levels in Dutch personnel cannot primarily be attributed to a comparatively worse health status. The threshold to report sick is considered to be higher in Belgium and Germany. As major frequency reducing factors operating in these countries the application of disciplinary measures (employer) and administrative and financial barriers have been identified (waiting day, certification). Differences in income loss, job protection, eligibility criteria for invalidity pension payment and administrative procedures may account for the large variations in duration of absences. Both for the employer and employee, the Dutch invalidity pension scheme seems to be comparatively attractive vis-à-vis other contingencies (unemployment, early retirement). Consequently an effect on increasing sickness absence is being noted.

After discussing some (alleged) effects of high sickness absence levels in the Netherlands (e.g. reduced health care expenditures, lower job stress, higher job satisfaction, higher density of insurance doctors) our findings have been put into a wider cross-cultural perspective. It is shown that striking differences between our countries may be related to variations in some dominant cultural dimensions in society. The weight attributed to regulations (to avoid uncertainty) or preferences to "feminine" norms (quality of life, sympathy for the weak) is being reflected in employers strategies, the tasks of insurance physicians, administrative procedures and work-related values and attitudes. It is concluded the cultural roots of our observed differences may preclude a simple transplantation of "foreign" elements or procedures. Notwithstanding, some aspects of the Dutch situation are considered that need further attention (i.e. 
moments and methods of evaluation in disablement benefit programme, health surveillance, rehabilitation, facilities). 


\section{SAMENVATTING}

Bij de discussies over de hoogte en ontwikkeling van het ziekteverzuim in Nederland komen onvermijdelijk vragen aan de orde over de situatie in het buitenland. Nu gaven in het begin van de jaren tachtig bepaalde overzichten en studies aan, dat het ziekteverzuim in Nederland tot de hoogste in Europa moest worden gerekend. Aangezien aan de gebruikte cijfers echter diverse beperkingen kleefden werd door het bestuur van de voormalige Stichting CCOZ (thans NIA) besloten een verkennende studie te laten verrichten. De probleemstelling van het onderzoek bestond uit twee vragen:

1. Wat zijn de verschillen in het ziekteverzuim van werknemers in België, WestDuitsland en Nederland?

2. Wat zijn hiervan de mogelijke achtergronden?

Het onderzoek is uit drie delen opgebouwd. Teneinde vertrouwd te raken met het thema werden eerst bestaande studies, wettelijke kaders en bestaande statistieken bestudeerd. In het tweede deel zijn de aard en omvang van de internationale verschillen onderzocht, terwijl in het derde deel wordt getracht om inzicht te krijgen in de achtergronden van onze bevindingen.

Hoofdstuk 2 doet verslag van het literatuuronderzoek naar de bronnen, opzet en conclusies van dertien publikaties die tussen 1964 en 1986 over ons thema verschenen. Behalve veel "macroscopische" studies (met geaggregeerde gegevens over werknemers- en verzekerdenpopulaties) werden ook enkele "mesoscopische" onderzoekingen aangetroffen (die gebruik hadden gemaakt van cijfers van vergelijkbare bedrijven uit verscheidene landen). Van diverse studies bleek de methodische basis erg beperkt te zijn, zonder dat hiervan voldoende rekenschap werd gegeven (beperkte vergelijkbaarheid van begrippen, grootheden en populaties). De gepresenteerde cijfers gaven echter meestal wel aan, dat Nederland hoog in de internationale ziekteverzuim-rangorde stond.

In Hoofdstuk 3 wordt de sociale verzekeringscontext van het ziekteverzuim vergeleken. Er blijken tussen de drie landen aanzienlijke verschillen te bestaan in structuur, uitvoering en uitkeringsniveau van de nationale ziektewetten. Opvallend is dat elders een aparte ongevallenverzekering voorkomt, terwijl de loondervingsregeling in geval van ziekte een aanzienlijk eigen risico voor werkgevers kent. Verder doen zich verschillen voor ten aanzien van wachtdagen, niveau en duur van de uitkeringen, en de legitimatie en controle van de arbeidsongeschiktheid. Op deze aspecten blijken de verschillen het grootst te zijn tussen Nederland en België, met respectievelijk de minste en de meeste restrictieve condities.

Ten behoeve van een valide meting en vergelijking van het ziekteverzuim 
wordt in Hoofdstuk 4 gekozen voor een vergelijking op bedrijfsniveau met gebruikmaking van individuele verzuimgegevens. Verzekeringstechnische, conceptuele en data-technische oorzaken van verschillen kunnen aldus zo veel mogelijk worden uitgeschakeld, terwijl doorkruisende populatiekenmerken eveneens onder controle kunnen worden gehouden. Het onderzoeksontwerp is gericht op het uitvoeren van case studies in enkele internationale clusters. Elk cluster bestaat uit drie bedrijven die qua produkt en produktieproces, grootte en ligging (industriegebied - platteland) sterk overeenkomen. Door de "matching" op deze criteria kan hun invloed op internationale verschillen worden uitgeschakeld. Voor het onderzoek konden vier clusters worden samengesteld met in totaal elf bedrijven (daar één Westduitse deelnemer zich terugtrok). De clusters zijn afkomstig uit de chemie (verfindustrie), levensmiddelenindustrie (margarine, diepvries) en metaalproduktenindustrie (blikverpakkingen), en omvatten tijdens onze waarnemingsperiode (1-1-1980 tot 1-1-1982) 11.127 werknemers.

Hoofdstuk 5 geeft een overzicht van de case studies die volgens een identieke opzet in de clusters werden uitgevoerd. In de vergelijking van verzuimpercentages, meldingsfrequenties en gemiddelde duur of duurklassen, blijken de Belgische bedrijven steeds het laagste ziekteverzuim te hebben. Teneinde de invloed van verschillen in leeftijdsopbouw, percentage mannen-vrouwen en soort werk (handarbeiders - beambten) uit te schakelen werden voor beide jaren gestandaardiseerde verzuimcijfers berekend. Hierdoor zijn de verschillen groter en duidelijker geworden. Onder Belgische werknemers is het verzuimniveau het laagst en in drie van de vier clusters komen bij de Nederlandse bedrijven de hoogste percentages en frequenties voor. Twee Westduitse bedrijven bevinden zich tussen beide niveaus en in één bedrijf ligt het verzuim iets boven het Nederlandse peil.

Een uitgebreide analyse van de structuur en duurzaamheid van de verzuimverschillen is in Hoofdstuk 6 opgenomen. Uit de gestandaardiseerde cijfers blijkt, dat de Nederlandse werknemers zich $70 \%$ meer ziek melden en een $90 \%$ hoger verzuimpercentage hebben dan hun Belgische collega's. De verschillen zijn het grootst voor middellange (1-6 weken) en langdurige (7-52 weken) verzuimgevallen: zowel de meldingen als het volume is twee keer zo hoog als bij het personeel in de Belgische bedrijven. Het Nederlandse ziekteverzuim wordt verder gekenmerkt door relatief veel frequent-verzuimers, weinig "nulverzuimers", een lage werkhervattingssnelheid en twee à drie keer zoveel personen met 1 jaar verzuim ("max.-gevallen") als in de Westduitse, respectievelijk de Belgische populatie.

Uit een trend-analyse van "ziektewetgegevens" wordt duidelijk dat in alle drie de landen sinds 1980 een soortgelijke ontwikkeling waarneembaar is (daling en wellicht stabilisatie). Een vergelijking over de jaren 1983-1987 van gewogen en gestandaardiseerde verzuimcijfers (gebaseerd op uitkeringsgegevens) ondersteunt grotendeels de conclusies uit de case studies. Volgens deze schattingen meldden de Nederlandse verzekerden zich in 1987 nog 50 respectievelijk $100 \%$ vaker ziek dan hun Westduitse en Belgische collega's. De incidentie van gevallen die langer dan zes weken duren ligt nog $80 \%$ boven het gemiddelde buitenlandse niveau. 
Het derde deel van het onderzoek is gericht op het vinden van verklaringen voor de gevonden verschillen. Allereerst worden in Hoofdstuk 7 de conclusies uit ziekteverzuimonderzoekingen in de drie landen vergeleken. Hieruit blijkt onder andere, dat verscheidene factoren en samenhangen een ruime externe geldigheid hebben en in elk land worden aangetroffen (bijvoorbeeld socio-demografische variabelen, werk- en bedrijfsgebonden kenmerken). Aansluitend op de beslissingstheoretische benadering werd een theoretisch referentiekader opgesteld. Hierin zijn gezondheids-, sociale, bedrijfsgebonden en institutionele factoren opgenomen en hun relaties met de ziektedrempel, verzuimdrempel en werkhervattingsdrempel in het individuele verzuimgedrag. Van het geheel van factoren en samenhangen kan slechts een beperkt deel geëxploreerd worden.

In de gekozen onderzoeksstrategie wordt eerst de samenhang van populatieen werkkenmerken met de ziekteverzuimverschillen statistisch verder onderzocht (Hoofdstuk 8). Multivariabele analyse (CANALS) bevestigt grotendeels de overeenkomstige samenhangen en risicogroepen die op basis van de literatuur werden verwacht. Een belangrijk internationaal verschil betreft het verloop. Belgische en Westduitse uitdiensttreders vallen op door hun hoge verzuimfre quentie, Nederlandse uitdiensttreders hebben met name een hoog verzuimpercentage. Een analyse van verzuimverschillen toont aan, dat deze het sterkst samenhangen met de variabele "land". De onderzochte persoons- en werkkenmerken geven met andere woorden geen verklaring voor de internationale verschillen.

In Hoofdstuk 9 vindt een vervolg op de eerdere case studies plaats, zij het op kwalitatieve wijze. De bedrijven in elk cluster zouden op drie terreinen vergeleken worden: personeelsbeleid, werkomstandigheden en bedrijfsgezondheidszorg, en ziekteverzuimbeleid. Aangezien de bereidwilligheid en medewerking internationaal zeer uiteenliepen, moest worden besloten alleen de informatie uit interviews met de betrokken personeelsfunctionaris en bedrijfsarts te vergelijken. Rekening houdend met de beperkte validiteit (sociale wenselijkheid) konden veel overeenkomsten en enkele verschillen worden geconstateerd. In Nederlandse bedrijven lijkt sprake te zijn van een uitvoering van een (breed) sociaal beleid, terwijl de Westduitse en Belgische personeelsafdelingen zich meer economisch georiënteerd - tot personeelsbeheer lijken te beperken. De Nederlandse bedrijfsarts besteedt (per 100 werknemers) minder tijd aan het bedrijf. Een aanzienlijk deel van de beschikbare tijd wordt aan ziektewetcontrole en verzuimbegeleiding besteed. Het eerste is de bedrijfsarts elders verboden, het tweede lijkt weinig te worden toegepast. De ten opzichte van buitenlandse bedrijven minder op discipline gerichte benadering van de personeelsfunctionaris weerspiegelt zich in de ruimere aandacht voor "begeleiding" en "overleg" en in minder nadruk op de toepassing van ontslag (wegens frequent verzuim). Het disciplinaire repertoire lijkt in de Belgische bedrijven het meest uitgebreid te zijn.

In Hoofdstuk 10 worden drie groepen maatschappelijke factoren nader onderzocht, namelijk loondervingsregelingen, mortaliteit en sociaal-culturele aspec- 
ten. De hogere frequentie van kortdurende gevallen in Nederland wordt, behalve met bedrijfsbeleidverschillen, in verband gebracht met de ongecompliceerde ziekmeldings- en legitimatieprocedures. Het hogere langdurige verzuim in Nederland kan voor een belangrijk deel worden toegeschreven aan een grotere ontslagbescherming, een hoog uitkeringsniveau en de relatief soepele toetredingscriteria voor de invaliditeitsverzekering (WAO).

Ten aanzien van het laatste blijken in Nederland jaarlijks gemiddeld twee keer zoveel toekenningen plaats te vinden dan in de ons omringende landen. Aanzienlijk hogere incidenties vallen op bij de jongere en middelbare leeftijdsgroepen en voor twee diagnose-hoofdgroepen: "psyche" (V) en "bewegingsstelsel" (XIII). Verder indiceren de gestandariseerde sterftecijfers, dat Nederlandse intreders in de WAO een relatief gunstige gezondheidstoestand, dan wel een ander mortaliteitspatroon hebben (non-letale klachten en aandoeningen) dan Belgische en Westduitse intreders. Het beeld van de invaliditeit is echter onvolledig: in de omringende landen kunnen ziekte en arbeidsongeschiktheid ook in andere regelingen verborgen zijn (werkloosheids-, gehandicaptenregelingen).

Voor de totale populaties geldt, dat de sterftecijfers en levensverwachting van Nederlanders gunstiger zijn dan die in West-Duitsland en België. Enkele andere indicatoren geven eveneens aan dat het Nederlandse ziektegedrag in bepaalde aspecten iets gunstiger afsteekt ten opzichte van het buitenland (bijvoorbeeld minder artsbezoek, lager medicijngebruik). Wat betreft sociaal-culturele verschillen blijkt in grote lijnen, dat Nederlandse werknemers relatief meer tevreden zijn met hun beloningsniveau en meer gewicht hechten aan niet-materiële werkaspecten (relaties, sfeer, arbeidsomstandigheden). Door de jaren heen blijken Nederlandse werknemers een ondermeer hogere arbeidssatisfactie te hebben dan hun Belgische en Westduitse collega's.

In het elfde hoofdstuk worden de conclusies uit de diverse deelprojecten geïntegreerd en besproken in het licht van het theoretische referentiekader. Vastgesteld wordt, dat verzuimcijfers een slechte ziekte-indicator zijn en dat het relatief hoge Nederlandse ziekteverzuimniveau in eerste instantie niet aan een gemiddeld slechtere gezondheidstoestand kan worden toegeschreven. De ziekmeldingsdrempel is voor Belgische en Westduitse werknemers hoger dan voor Nederlandse personeelsleden (vanwege werkgeversbeleid, administratieve en financiële belemmeringen). Door factoren als inkomensachteruitgang, ontslagrisico, controle-methodiek en hoge invaliditeits-toetredingscriteria ligt elders de werkhervattingsdrempel lager. Uit enkele cross-culturele studies ontstaat het beeld dat de variaties in ziektegedrag, bedrijfsbeleid, loondervingsregelingen, en dergelijke, met culturele verschillen in verband kunnen worden gebracht (bijvoorbeeld normen en waarden met betrekking tot regulering, het vermijden van onzekerheid of zorg voor de zwakkeren en dergelijke). Deze verschillen weerspiegelen zich in bijvoorbeeld vanzelfsprekendheden ten aanzien van medische attestering, disciplinerende of begeleidende benaderingen, de scheiding van behandeling en controle of het nastrevenswaardige niveau van sociale voorzieningen, etcetera. Na een bespreking van de (mogelijke) effecten van een hoog verzuimniveau (bijvoorbeeld ten aanzien van individuele kosten, arbeidssatisfactie, stakingsdagen), worden kort enkele aandachtspunten voor het beleid besproken (ZW/WAO-uitvoering, bedrijfsgezondheidszorg, revalidatie). 


\section{BIBLIOGRAPHY}

Aarts, L.J.M., Bruinsma, H., Emanuel, H., Hop, J.P., de Jong, Ph.R., Van Praag, B.M.S., (1987), Determinantenonderzoek WAO; eindrapportage (Research into determinants of the development of the DSA Benefit Programme), Sociale Verzekeringsraad, Zoetermeer.

André, M. (1985), The various early retirement provisions in Belgium. In: International Social Security Association, Social security, unemployment and premature retirement, Geneva, pp. 26-40.

Adriaenssens, P. (1985), Ziekteverzuim in België (Sickness absence in Belgium), Universitaire Instelling, Antwerpen.

Anderson, S. et al. (1980), Statistical methods for comparative studies, Wiley, New York.

Andriessen, S., Holthuis, R., Prins, R. (1983), Sociaal-medische betrokkenbeid bij ziekte- en arbeidsongeschiktheidsregelingen; een internationale verkenning (Socio-medical guidance in case of sickness and disability; an international exploration), Ministerie van Sociale Zaken en Werkgelegenheid, Den Haag.

Arbeits- und Sozialministerium Baden-Württemberg (1971), Modell einer allgemeinen Vorsorgeuntersuchung; Zwischenbericht (Model of general health screening; provisional report), Stuttgart.

Bauer, G. (1981), Work absence: the position in the Federal Republic of Germany. In: International Social Security Association, Absenteeism and social security, Geneva, pp. 112-126.

Bax, E.H. (1985), Macro-determinanten van arbeidsongeschiktheid (Social determinants of work incapacity), Economisch-Statistische Berichten, 2, pp. 81-89.

Becker, M.H. \& Maiman, L.A. (1983), Models of health-related behavior. In: D. Mechanic (ed.), Handbook of health care and the bealth professions, The Free Press, New York, London, pp. 539-568.

Behrend, H. (1974), A new approach to the analysis of absences from work. Industrial Relations Journal, 5, pp. 4-21.

Blalock, H.M. (1960), Social statistics, McGraw-Hill, New York.

Blomsma, M. \& de Vroom, B. (1988), Veruroegd uittreden uit betaalde arbeid (Early retirement from paid employment), Harmonisatieraad Welzijnsbeleid, 's-Gravenhage.

Böker, K. (1971), Entwicklung und Ursachen des Krankenstandes der Westdeutschen Arbeiter (Trend and causes of sickness absence in Westgerman workers). In: Nieder,P. (ed.) Fehlzeiten, ein Unternebmer oder Arbeitnehmerproblem?, Haupt, Bern, pp. 181-193.

Bouquet, R. (1979), Insurance against incapacity for work in European Law. International Social Security Review, 4, pp. 443-464. 
Bratt, C. (1982), Labor relations in 17 Countries, Swedish Employers Confederation, Stockholm.

Breitrück, N., Loibl, F., Wübbels, R. (1987), Zahlenwerk zur Sozialversicherung in der BRD (Data on social security in the FRG), Erich Schmidt Verlag, Berlin.

Brill, W. (1984), Der Nachweis der Arbeitsunfähigkeit des Arbeiters (The evidence of a workers incapacity to work), Die Ortskrankenkasse, 6, pp. 218-221.

Brouwer, W.S. \& Vrijhof, B.J. (1989), Ziekteverzuim 1986-1987 (Sickness absence 1986-1987), Nederlands Instituut voor Arbeidsomstandigheden, Amsterdam.

Bruinsma, H. \& Emanuel, H. (1981), Social and economic factors underlying the rise in the number of disability pensioners. In: International Social Security Association, Social security and disability; issues in policy research, Geneva, pp. 28-54.

Bundesminister für Arbeit und Sozialordnung (1983...1988a), Arbeits- und Sozialstatistik, Hauptergebnisse (Labour and social statistics; main results), Bonn.

Bundesminister für Arbeit und Sozialordnung (1980...1987b), Die Rentenversicherung der Arbeiter und der Angestellten in der BRD (Manual workers and salaried employees pension insurance in the FRG), Bonn.

Bundesverband der Ortskrankenkassen (1980...1987), Krankheitsartenstatistik (Sickness statistics), Bonn.

Bunnage, D.A. (1981), Current research into work absence at the Danish National Institute of Social Research. In:International Social Security Association, Absenteeism and social security, Geneva.

Bureau van de Statistiek der Europese Gemeenschap (1988a), Basisstatistieken van de Gemeenschap (Basic statistics on the community), Luxemburg.

Bureau van de Statistiek der Europese Gemeenschap (1988b), Eurostat Review 1977-1986, Luxemburg

Bürkardt, D. \& Oppen, M. (1983), Krankenstandsforschung zwischen Personal- und Gesundheitpolitik - ein kritischer Überblick über vorliegende Untersuchungsansätze (Sickness absence research between personnel management and health policy: a critical overview of present research theorems). In: Volkholz et al., Kosten der Arbeitsunfäbigheit, Bundesanstalt für Arbeitsschutz, Dortmund.

Busch, K. (1982), Krankenstand: Einzelaspekte (Some aspects of sickness absence), Bundesarbeitsblatt, 9, pp. 8-13.

Buijs, P.C. (1985), Curatieve gezondheidszorg, ziekteverzuim en arbeidsongeschiktheid (Curative health care, sickness absence and disability), Stichting CCOZ, Amsterdam.

Casselman, J. \& Knibbe, R.A. (1985), Alcoholgebruik en alcoholproblemen in België en Nederland (Alcohol consumption and alcohol-related problems in Belgium and The Netherlands), Gezondheid en Samenleving, 6, pp. 256-264.

Centraal Bureau voor de Statistiek (1982...), Diagnose-statistiek bedrijfsverenigingen; omslagleden (Diagnosis statistics occupational association's members), 's-Gravenhage.

Centraal Bureau voor de Statistiek $(1984,1987)$, De leefsituatie van de Nederlandse bevolking 1983, 1986; kerncijfers (Well-being of the population in the Netherlands 1983, 1986; key figures), Staatsuitgeverij, Den Haag. 
Centraal Bureau voor de Statistiek (1988), Statistisch Zakboek 1987 (Statistical pocketbook, 1987), Voorburg.

Chadwick-Jones, K., Nicholson, N., Brown, C. (1982), Social psychology of absenteeism, Praeger, New York.

Child, J. \& Kieser, A. (1979), Organizational and managerial roles in British and West German companies: an examination of the culture-free hypothesis. In: Lammers, C.J. \& Hickson, D.J. (Eds), Organizations alike and unlike, Routledge \& Kegan Paul, London, pp. 251-271.

Commissie van de Europese Gemeenschappen $(1982,1986)$, Vergelijkende tabellen van de stelsels van sociale zekerbeid (Comparative tables of social security), Luxemburg.

Copeland, L.S. (1977), Defining disability; a cross-country study, U.S. Department of Health, Education and Welfare, Washington.

Copeland, L.S. (1981), International trends in disability program growth, Social Security Bulletin, 44, 10, pp. 25-36.

De Groot, M.W. (1971), De "geestelijke verzieking" van het Nederlandse volk: slogan of realiteit? (The Dutch people mentally diseased: slogan or reality?), Medisch Contact, 26, pp. 815822.

De Winter, C.R. \& Dijkstra, A. (1984), De bedrijfsarts over zijn werk (The occupational physician and his work), Nederlands Instituut voor Preventieve Gezondheidszorg/TNO, Leiden.

Dennerlein, R. \& Schneider, M. (1985), Untersuchung der Bestimmungsfaktoren für Schwankungen des Krankenstandes in der Bundesrepublik Deutschland von 1960-1983 (Investigation on determinants of fluctuations in sickness absence in de Federal Republic of Germany, 1960-1983), Bundesminister für Arbeit und Sozialordnung, Bonn.

Depijpere, M. (1985), Arbeidsongeschiktheid in de ziekteverzekering, (Work incapacity in sickness insurance), Leuven.

Diller, W.F. \& Fegers, S. (1979), Die Arbeitsmedizin in den EG-Ländern (Occupational health care in European Community countries), Verlag für Medizin Dr. Fischer, Heidelberg.

Drenth, P.J. (1983), Centraliteit van werken (Work centrality), Vrije Universiteit, Amsterdam.

Eidenmüller, K. (1985), Changes in the structure of old-age and early retirement pensions due to the introduction of flexible retirement. In: International Social Security Association, Social security, unemployment and premature retirement, Geneva, pp. 130-149.

Eindhovense Fabrikanten Kring (1979), Ziekteverzuim, een beel probleem! (Sickness absence, quite a problem!), Eindhoven.

Ekker, W. (1966), Ziekteverzuim als bedrijfskenmerk, (Sickness absence as a company characteristic), Mens en Onderneming, 20, pp. 1-11.

Emanuel, H. (1980), Factors in the growth of the number of disability beneficiaries in the Netherlands, International Social Security Review, 43, pp. 41-60.

Emanuel, H., Halberstadt, V., Petersen, C. (1984), Disability policy in the Netherlands. In: Haveman, R.H., Halberstadt, V., Burkhauser, R.V. (eds.), Public policy toward disabled workers: cross-national analysis of economic impacts, Cornell University Press, Ithaca and London, pp. 399-443. 
Enterline, P.E. (1964), Sick absence in certain western countries, Industrial Medicine and Surgery, pp. 738-741.

Enterline, P.E. (1966), Social causes of sick absence, Arch. Environ. Health, 12, pp. 467-473.

Eschweiler, W., Hinze, D., Nieder, P. (1979), Beschreibung und Ergebnisse einer empirischen Untersuchung zur Erfassung der Ursachen von Fehlzeiten (Description and results of an investigation on the causes of absenteeism). In: Nieder, P. (ed), Feblzeiten, ein Unternehmer oder Arbeitnebmerproblem?, Haupt, Bern, pp. 109-129.

Falke, J., Höland, A., Rhode, B., Zimmermann, G. (1981), Kündigungspraxis und Kündigungsschutz in der BRD; Band 2 (Dismissals and job security in the FRG; Volume 2), Bundesminister für Arbeit und Sozialordnung, Bonn.

Field, M.G. (1975), The need for cross-national studies in health services. In: Pflanz, M. \& Schach, E., (eds.), Cross-national socio-medical research: concepts, methods, practice, Georg Thieme Publications, Stuttgart, pp. 3-11.

Gadourek, I. (1965), Absences and well-being of workers, Van Gorcum, Assen.

Gastarbeiter in Europa (1984), (Migrant workers in Europe), Bundesarbeitsblatt, 5, pp. 32.

Geerts, A. (1976), Schatting van de invaliditeit in de Belgische ziekte-en invaliditeitsverzekering (Assessment of invalidity in Belgian sickness- and disablement insurance), Tijdschrift voor Sociale Geneeskunde, 54, pp. 117-124.

Gemeenschappelijke Medische Dienst (1969...1989), Jaarverslag; statistische informatie $1980 . . .1988$ (Annual report; statistical information 1969...1988), Amsterdam.

Georg A., Stuppardt, R., Zoike, E. (1982), Krankheit und Arbeitsbedingte Belastungen; Band 2 Engebnisse (Illness and work-related stress; Volume 2, Results), Bundesverband der Betriebskrankenkassen, Essen.

Gevers, J.K.M., Wetgeving inzake de bedrijfsgezondheidszorg in de Europese Gemeenschap, I, II, (Legislation on occupational health care in the European Community, I, II), Tijdschrift voor Sociale Geneeskunde, 80, 10, pp. 259-266; 11, pp. 282-285.

Grais, B. (1983), Lay-offs and short-time working in selected OECD-countries. Organization for Economic Cooperation and Development, Paris.

Groothoff, J.W. (1986), Gezondheidstoestand van de beroepsbevolking (Health status of the employed population), Rijksuniversiteit Groningen.

Grosfeld, J.A.M. (1988), De voorspelbaarbeid van individuele verzuimduur, (Predictability of individual absence lengths), Swets \& Zeitlinger, Amsterdam.

Gut P., Steffens, E.J., Thiele, W. (1983), Strukturanalyse der Arbeitsunfähigkeit (Structural analysis of work incapacity). In: Volkholz, V. et al., Kosten der Arbeitsunfähigkeit, Bundesanstalt für Arbeitsschutz, Dortmund, pp. 71-115.

Halin, M.A. (1988), De tafels van intrede in invaliditeit (Invalidity incidence tables), Rijksinstituut voor Ziekte en Invaliditeitsverzekering, Brussel.

Halusa, G., Oppen, M., Bürkhardt, D., Schneider, M. (1982), Berliner Krankenstand im Kontext regionsspezifischer Bedingungsfaktoren (Regional conditions and sickness absence in 
Berlin), Bundesminister für Forschung und Technologie, Berlin.

Harding, S., Philips, D., Fogarty, M. (1986), Contrasting values in Western Europe; unity, diversity and change, The Macmillan Press LTD/European Value Systems Study Group, Houndsmill.

Haveman, R.H. \& Halberstadt, V. (1983), Public income support to disabled workers: issues of program growth, costs, and labor supply in a crossnational context. In: Pfaff, M. (ed.), Effizienz und Effektivität staatlicher Transferpolitik in der Wirtschaftskrise, Berlin, pp. 233255.

Haveman, R., Halberstadt, V., Burkhauser, R.V. (1984), Public policy towards disabled workers; cross-national analysis of economic impacts, Cornell University Press, Ithaco/London.

Heesters, J.P. \& Kesenne, J. (1985), Financiering en kosten van gezondheidszorg in Nederland en België (Cash flows and costs of health care system in the Netherlands and in Belgium), Gezondheid en Samenleving, 6, nr. 4, pp. 311-320.

Henderickx, E. (1978), Ziekteverzuim als instabiliteitsgedrag; een multicausaal probleem (Sickness absence as instability behaviour; a multicausal problem), Tijdschrift voor Sociale Wetenschappen, 23, pp. 17-41.

Henderickx, E. (1985), Afwezigheid wegens ziekte; een empirisch onderzoek naar het strategisch bandelen van arbeiders en bedienden (Absence from work; an empirical study of strategic action of workers and staff), Gent University, Gent.

Hinze D.A. (1982), Determinanten der Arbeitsverweigerung; eine empirische Untersuchung der Einflussfaktoren auf industriellen Absentismus (Determinants of work refusal; an empirical study of causal factors on industrial absenteeism), Wilfer, Spardorf.

Hofstede, G. (1980), Culture's consequences; international differences in work-related values, Sage publications, Beverly Hills, London.

Hofstede, G. (1983), Dimensions of national cultures in fifty countries and three regions. In: Deregowski, J.B., Dziurawiec, S. \& Annis, R.C., Expiscations in cross-cultural psychology, Swets and Zeitlinger, Lisse.

Hofstede, G. (1987), Gevolgen van het Nederlanderschap; gezondheid, recht en economie (Consequences of being Dutch; health, law and economy), Maastricht.

Hogerzeil, H.H.W. (1972), Arbeidsongeschiktheid en medisch-sociaal beleid (Medico-social policy and unfitness for work), Tijdschrift voor Sociale Geneeskunde, 50, pp. 538-550.

Huybrechs, J. (1985), De situatie van de uitkeringsgerechtigden in 1985. dossier, 12, pp. 1-100.

Iken, J. \& Haberkorn, K. (1982), Praktische Methoden zur Reduzierung von krankheitsbedingten Feblzeiten (Practical methods to reduce illness-related absenteeism), Weka-Verlag, Kissing.

Institut der Deutschen Wirtschaft (1984), Feblzeiten: Vorteile für Japan und USA (Absenteeism: advantages for Japan and the USA), Informationsdienst des Institut der Deutschen Wirtschaft, Köln.

Institut der Deutschen Wirtschaft (1985), International economic indicators 1985, Köln.

Institut der Deutschen Wirtschaft (1989), Sozialraum Europa (Social features of Europe), Köln.

International flexible retirement options (1982), European Industrial Relations Review, 107, pp. 16-21. 
International Labour Office (1984), World labour report (1), Geneva.

International Survey Research Limited (1987), Employee attitudes towards their employers; an European perspective, London.

Jansen, G.J. (1983), Ziekteverzuim van Turkse, Marokkaanse en Nederlandse werknemers in overeenkomende werksituaties (Sickness absence in Turkish, Maroccan and Dutch employees with similar working conditions), GAK, Amsterdam.

Johnsson, E. \& Neuhauser, D. (1979), Structural differences between Swedish and US hospitals. In: Lammers, C.J. \& Hickson, D.J., Organizations alike and unlike, Routledge \& Kegan Paul, London, pp. 287-303.

Kaim Caudle, P.R. (1973), Comparative social policy and social security; a ten-country study, Martin Robertson, London.

Kars-Marshall, C. (1983), Sociaal beleidsonderzoek in ontwikkelingslanden (Social policy research in developing countries), Lisbon/Vuga, Den Haag.

Kennedy, T. (1980), European labor relations; text and cases, Lexington Books, Toronto.

Kentner, M., Hop, W., Weltle, D., Valentin, H. (1983), Frübinvalidität in der BRD und in West Berlin von 1950-1980; Ursachen, Entwicklung, Bedeutung (Early retirement in the FRG and in West Berlin 1950-1980; causes, trend, interpretation), Deutscher Ärzte-Verlag, Köln.

Kern, K.D. (1984), Gesundheitszustand der Bevölkerung: Ergebnisse des Mikrozensus April 1982 (Population health status: survey results April 1982), Wirtschaft und Statistik, 4, pp. 335-340.

Klaric, D. (1982), Les raisons d'absence ou l'absence des raisons (The reasons for absence or the absence of reasons), Editions de l'Université de Bruxelles, Bruxelles.

Kramer, I., Verbaan, D., Wiersma, H. (1982), Ziekteverzuim: een Hollandse ziekte? (Sickness absence: a Dutch disease?), Philips, Afd. Sociale Zaken, Eindhoven.

Kramer-van der Zee, H. \& Verbaan, D. (1982), Buitenlandse werknemers en ziekteverzuim (Migrant employees and sickness absence), Philips, Eindhoven.

Kruidenier, H.J. (1984), Ziekteverzuim en verloop (Sickness absence and turnover), Stichting $\mathrm{CCOZ}$, Amsterdam.

Lebeer, L. (1981), Absence from work in Belgium. In: International Social Security Association, Absenteeism and social security, Geneva, pp. 101-111.

Lefelmann, G. (1984), Krankenstand, Lohnfortzahlung und konjunkturelle Entwicklung (Sickness absence, wage payment and economic development), Die Ortskrankenkasse, 22, pp. 863-872.

Mackenbach, J.P. (1989), Health status indicators: mortality. Paper presented at the Workshop on "Pluralistic health care system in Europe", Maastricht, July 5-6.

Maib J. (1981), Feblzeiten; Eine Untersuchung zu Begriff, Struktur und Bedingungen des Abwesentheitsverbalten von Arbeitnehmern (Absenteeism: an investigation on concepts, structure and conditions of employee absence behaviour), Göttingen.

Maroy, L. (1989), De arbeidsongeschiktheidsdefinitie van de Belgische ziekte- en invaliditeitsverzekering in berstelperspectief (The work incapacity definition in Belgian sickness- and invalidity insurance; a recovery perspective), Tijdschrift voor Verzekeringsgeneeskunde, 27, pp. 39-44. 
Mörschel, R. \& Rehfeld, U. (1981), Untersuchung der Rentenzugänge im Zeitablauf; Teil 1 (Investigation of new pension recipients in time arrays; Part 1), Deutsche Rentenversicherung 4, pp. 234-253.

Mokrzycki, E. (1979), On the adequacy of comparative methodology. In: Berting, J., Geyer, F., Jurkovich, R.(Eds), Problems in international comparative research in the social sciences, Pergamon Press, Oxford, pp. 93-104.

Münstermann, J. (1987), Statistischer Bericht über den Vertrauensärztlichen Dienst 1978 bis 1985 (Statistical report on the Vertrauensärztlichen Dienst, 1978 till 1985). Arbeitsgemeinschaft für Gemeinschaftsaufgaben der Krankenversicherung, Essen.

Nederlands Instituut voor Preventieve Gezondheidszorg/TNO (1983), Ziekteverzuim, WAO-intrede en verzekeringsvorm in de Ziektewet. (Sickness absence, invalidity and administration of sickness Benefits Act), Ministerie van Sociale Zaken en Werkgelegenheid, Den Haag.

Nederlands Instituut voor Preventieve Gezondheidszorg/TNO (1989), Het ziekteverzuim in 1988 (Sickness absence in 1988), Leiden.

Nefarma (1986), Farma feiten (Pharma facts), Utrecht.

Netherlands Scientific Council for Government Policy (1978), Do we make our business work?, Wetenschappelijke Raad voor het Regeringsbeleid, The Hague.

Nieder, P. (1978), Zur Reduzierung von Fehlzeiten; ein Bericht über ein Forschungsprojekt und seine Ergebnisse (Reduction of work absence; report on an investigation and its results), Zeitschrift für Arbeitswissenschaft, 3, pp. 187-190.

Nieder, P. \& Blaschke, D. (1979), Zur Bedeutung, Definition und Erfassung von Fehlzeiten (Meaning, definition and measurement of absenteeism). In: Nieder, P., Feblzeiten, ein Unternehmer- oder Arbeitnehmerproblem?, Haupt, Bern.

Nijhuis, F.J.N. (1984a), Beoordeling van organisatiekenmerken (Evaluation of organizational characteristics), Rijksuniversiteit Limburg, Maastricht.

Nijhuis, F.J.N. (1984b), Economische achteruitgang in bedrijven en ziekteverzuim (Economic recession in firms and sickness absence), Mens en Organisatie, 5, pp. 400-412.

Nijhuis, F.J.N., Soeters, J., Schröer, K., Philipsen, H. (1985), Twee onderzoeksmethoden bij studie van arbeid en ziekteverzuim (Two research methods for the investigation of work and sickness absence), Tijdschrift voor Sociale Gezondheidszorg, 63, 8, pp. 355-361.

Noelle-Neuman, E. \& Strümpel, B. (1985), Macht Arbeit krank? Macht Arbeit Glücklich? Eine aktuelle Kontroverse (Does work make you ill, does work make you happy? A topical controversy), Piper, München.

Noten für Arbeitnehmer (1989), (Grades for employees), Bundesarbeitsblatt, 9, pp. 20.

Nyman, K. \& Raitasalo, R., (1981), Work absence and some background factors in Finland. In: International Social Security Association, Absenteeism and social security, Geneva, pp. 12-28.

Oldiges, F.J. (1984), Long-term care of the elderly and disabled in the FRG. In: International Social Security Association, Long-term care and social security, pp. 106-116.

Ondernemers moeten minder op hun geld zitten (1989), (Employers should not sit on their money), NRC Handelsblad, 7 juni 1989. 
Organization for Economic Cooperation and Development (1987), Financing and delivering health care; a comparative analysis of $O E C D$ countries, Paris.

Organization for Economic Cooperation and Development (1989), Labour Force Statistics 1980-1987, Paris.

Paoli, C. (1982), Women workers and maternity: some examples from West Europe, International Labour Review, 1, pp. 1-15.

Pascale, R.T., Maguire, M.A. (1980), Comparison of selected work factors in Japan and the United States, Human Relations, 33, pp. 433-455.

Pasmooij, J.H. (1981), The Dutch occupational associations policy on sickness absence. In: International Social Security Association, Absenteeism and Social Security, Geneva, pp. 127137.

Payer, L. (1989), Medicine and culture; notions of health and sickness in Britain, the U.S., France and West Germany, Victor Gollancz Ltd., London.

Peeters, R.F., Van Sprundel, M., Meheus, A.Z. (1982), Ziektegedrag bij migranten; afwezigheid op het werk wegens ziekte bij Marokkanen (Sickness behaviour in migrants; sickness absence in Maroccans), Tijdschrift voor Sociale Geneeskunde, 60, 11, pp. 278-281.

Peeters, R.F., Stevens, F.E.J., \& Van der Zee, J. (1985), Basisgegevens van de Nederlandse en Belgische systemen van gezondheidszorg en sociale zekerheid bij ziekte en invaliditeit (Basic data on Dutch and Belgian health care systems and social security in case of sickness and invalidity), Van Loghem Slaterus, Deventer.

Pfaff, A., Deimer, K., Jaufmann, D., Kistler, E., Pfaff, M., Stark, E. (1986), Vergleich von Niveau und Entwicklung der Arbeitsfähigkeit in der BRD und in ausgewäblten Ländern (Comparison of magnitude and development of work incapacity in the FRG and in selected countries), Der Bundesminister für Arbeit und Sozialordnung, Bonn.

Pflanz, M. (1975), Problems and methods in cross-national comparisons of diagnoses and diseases. In: Pflanz, M. \& Schach, E. (eds), Cross-national socio-medical research: concepts, methods, practice, Georg Thieme Publishers, Stuttgart, pp. 60-68.

Philipsen, H. (1969), Afwezigheid wegens ziekte (Sickness absence), Wolters-Noordhoff N.V., Groningen.

Philipsen, H. (1977), Levensfase, generatie en ziekteverzuim (Life situation, generation and sickness absence), Rijksuniversiteit Limburg, NIPG/TNO, Maastricht.

Philipsen, H. (1985), Gezondheid en gezondheidszorg in België en Nederland (Health and health care in Belgium and the Netherlands), Gezondbeid en Samenleving, 6, nr. 4, pp. 223231.

Philipsen, H. (1988), Gezondheidszong als project en bejegening; waarden ten aanzien van ziekte, gezondheid en samenleving (Health care as project and treatment; values on illness, health and society). Rijksuniversiteit Limburg, Maastricht.

Philipsen, H. \& Halfens, R. (1983), Niet werken en gezondheid; een vergelijking van arbeidsongeschikten, vervroegd gepensioneerden en werklozen met werkende mannen (Not being employed and health; a comparison across disabled, early retired, unemployed and employed males). Gezondheid en Samenleving, 4, pp. 161.168. 
Poelstra, P.A.M., Dronkers, J., \& Jacobi, A.M. (1985), Verschillen in ziektewetcontrole tussen bedriffserenigingen (Differences between occupational associations regarding sickness benefit supervision), Federatie van Bedrijfsverenigingen, Amsterdam.

Porter, L.W. \& Steers, R.M. (1973), Organizational, work, and personal factors in employee turnover and absenteeism. Psychological Bulletin, 80, 2, pp. 151-176.

Prins, R. (1981), Arbeidsverzuim in internationaal perspektief: enkele kanttekeningen bij buitenlandse verzuimciffers (Absenteeism in an international perspective; some comments on foreign absence rates), $\mathrm{CCOZ}$, Amsterdam.

Prins, R. \& Andriessen, S. (1983), Internationaal vergelijkend Onderzoek Ziekteverzuim; deel 1 Verzekeringstechnische en arbeidsrechtelijke aspekten van bet ziekteverzuim in België, WestDuitsland en Nederland (Cross-national study on sickness absence; part 1: Social security and labour judicial aspects of sickness absence in Belgium, West Germany and the Netherlands), CCOZ, Amsterdam.

Prins, R. (1984), Krankenstand in der Bundesrepublik Deutschland, Belgien und den Niederlanden; Krankenversicherung, Arbeitsrecht und betriebsmedizinische Versorgung (Sickness absence in the Federal Republic of Germany, Belgium and the Netherlands; sickness insurance, labour law and occupational health care), Stichting $\mathrm{CCOZ}$, Amsterdam.

Prins, R. (1985), Ziekteverzuim in België, West-Duitsland en Nederland; institutionele context en enkele cijfers (Sickness absence in Belgium, Germany and the Netherlands; institutional context and some figures), Tijdschrift voor Sociale Gezondheidszorg, 63, pp. 308-315.

Prins, R. \& De Graaf, A. (1986), Comparison of sickness absence in Belgian, German and Dutch firms, British Journal of Industrial Medicine, 42, pp. 529-536.

Prins, R. \& Peeters, R. (1986), Afwezigheid wegens ziekte in België en Nederland (Absence due to sickness in Belgium and the Netherlands), Gezondheid en Samenleving, 7, pp. 296-303.

Przeworski, A. \& Teune, H. (1970), The logic of comparative social inquiry. Wiley, New York.

Rindt, M. (1988), Behinderte: im Arbeitsleben leistungsfähig (Handicapped: skilful on the labour market), Bundesarbeitsblatt 6, pp. 8-13.

Rodgers, B., Doron, A., Jones, M. (1979), The study of social policy: a comparative approach, George Allen \& Unwin, London.

Rijksinstituut voor Ziekte- en Invaliditeitsverzekering (1980...1988), Uitkeringsverzekering: financiële en statistische gegevens (Benefits insurance: financial and statistical data), Brussel.

Salowsky, H. (1980), Individuelle Fehlzeiten in westlichen Industrieländern, (Individual absenteeism in Western industrial countries), Institut der Deutschen Wirtschaft, Köln

Salowsky, H. (1983), Feblzeiten; ein internationaler Vergleich (Absenteeism: a cross-national comparison), Institut der Deutschen Wirtschaft, Köln.

Schlegel, M. (1982), Krankenstand, Analyse der Entwicklung in der gesetzlichen Krankenversicherung von 1954 bis 1980 (Sickness absence, analysis of its development from 1954 to 1980), Die Ortskrankenkasse, pp. 513-519.

Schokking-Siegerist, E.C. (1981), Work absence in women. In: International Social Security Association, Absenteeism and Social Security, Geneva, pp. 58-72.

Schregle, J. (1981), Comparative industrial relations: pitfalls and potential, International Labour Review, pp. 120, 1, 15-30. 
Seffen, A. (1980), Einkommenssicherung bei Krankheit in westlichen Industrieländern (Income maintenance in case of sickness in Western industrial countries), Institut der Deutschen Wirtschaft, Köln.

Sichrorsky, P. (1984), Krankbeit auf Rezept; Die praktiken der Praxisärzte (Illness by prescription; the practices of general physicians), Kiepenheuer \& Witsch, Köln.

Silomon, H. (1978), Die Diagnose und Bescheinigung des Arztes in der Sozialversicherung (Diagnosis and certification by social insurance physicians. In: Silomon, H., Sozialmedizin, eine Einfübrung für Sozialversicherungsfachleute, Asgard Verlag, Sankt Augustus, pp. 161171.

Silomon, H. (1983), Arbeitsunfähigkeit: ihr Ausmass und Trend - die Organisation ihrer Kontrolle und deren Ergebnisse (Scale and trends in work incapacity; the organization of supervision and its results), Das offentliche Gesundheitswesen, 45, 7, pp. 374-379.

Smelser, N.J. (1976), Comparative methods in the social sciences, Prentice Hall, Englewood Cliffs.

Smulders, P.G.W. (1983), Personal, nonwork and work characteristics in male and female absence behaviour, Journal of Occupational Behavior, 4, pp. 285-295.

Smulders, P.G.W. (1984a), Balans van 30 jaar ziekteverzuimonderzoek, de resultaten van 318 studies samengevat (Balance of 30 years of research on sickness absence; results of 318 studies summarized), NIPG/TNO, Leiden.

Smulders, P.W.G. (1984b), Bedrijfskenmerken en ziekteverzuim in de jaren 60 en 80; een vergelijkende studie, (Organizational characteristics and sickness absence in the sixties and eighties; a comparative study), NIPG/TNO, Leiden.

Sociale Verzekeringsraad $(1987,1988)$, Stand Ziekengeldverzekering, Zoetermeer.

Soeters, J. (1980), Afwezigheid wegens ziekte in het herstruktureringsgebied Zuid-Limburg (Sickness absence in Southern Limburg), Rijksuniversiteit Limburg, Maastricht.

Soeters, J. (1983), Patiënt, gezondheidszorg en langdurige ziekte (Patient, health care and prolonging sickness), Rijksuniversiteit Limburg, Maastricht.

Soeters, J. \& Prins, R. (1985), Health care facilities and work incapacity: a comparison of the situation in the Netherlands with that in six other West European countries, International Social Security Review, 2, pp. 141-156.

Sozialstatistik (social statistics), Bundesarbeitsblatt, $(1987,1988)$ Tabellen 3.2, 371, pp. 133, 75.

Spiegelhalter F. \& Schnabel, F. (1962), Die Struktur des Krankenstandes in der Industrie (The structure of sickness absence in industry), Der Arbeitgeber, 10, pp. 302-307.

Stoetzel, J. (1983), Les valeurs du temps present: une enquête européenne, Presses Universitaires de France, Paris.

Sturmans, F., Van Dongen, M.C.J.M , \& Zielhuis, S.A. (1982), Naar een gezonde werkomgeving; epidemiologie binnen de bedrijfsgezondheidszorg (Towards a healthy work environment; epidemiology in occupational health care), Dekker \& Van de Vegt, Nijmegen.

Taylor, P.J. (1969), Some international trends in sickness absence 1950-1968. British Medical Journal, 4, pp. 705-707. 
Taylor, P.J. (1972), International comparisons of sickness absence, Proc. Roy. Soc. Med., 65, pp. 577-586.

Taylor, P.J. (1983), Absenteeism: definition and statistics. In: International Labour Organization, Encyclopaedia on occupational health and safety, Geneva, pp. 8-10

Thorpe, J.J. (1965), Summary of sickness absenteeism data from European affiliates, Medical Bulletin, 25, 2, pp. 118-130.

Thorpe, J.J. (1968), Review of sickness absence data, 1964-1966, Medical Bulletin, 28, pp. 121127.

Tordoir, W.F., Klauw, M.M. van der, Maanen-Boekestein, C.M.J. van (1978), Gezondheidszorg en lange ziekteduren (Health care and prolonging sickness absence), NIPG/TNO, Leiden.

Trebesch, K. (1979), Fehlzeiten in Betrieb und Verwaltung (Absenteeism in private and public organizations). In: Nieder, P., Feblzeiten, ein Unternehmer- oder Arbeitnehmerproblem? Haupt, Bern.

U.S. Department of Health and Human Services (1984, 1986, 1988), Social security programs throughout the world (1983, 1985, 1987), Washington.

Van der Burg, E. (1985), CANALS, Department of Data theory, Leiden.

Van der Horst, F.G.E.H. (1988), Gezondheid en niet-werken: een vergelijkend onderzoek naar gezondheid en leefwijze van werklozen, arbeidsongeschikte, vervroegd gepensioneerde en werkende mannen (Health and non-employment; a comparative inquiry into health and life style of unemployed, disabled, early retired and working men), Rijksuniversiteit Limburg, Maastricht.

Van der Krieke, M. (1983), Effekten van medische en niet-medische Ziektewetcontrole op bet ziekteverzuim (Effects of medical and non-medical supervision of claims for sickness benefits), Gemeenschappelijk Administratie Kantoor, Amsterdam.

Van Engers, R. (1987), Ziekteverzuim van vrouwen (Sickness absence in females), GAK, Amsterdam.

Van Hall, G., Peeters, R., Eylenbosch, W. (1986), Ziekteverzuim bij het personeel van het openbaar centrum van maatschappelijk welzijn. Antwerpen, 1984 (Sickness absence in employees of the Social Welfare Centre Antwerp, 1984), Tijdschrift voor Sociale Geneeskunde, 64, 23, pp. 737-738.

Van Steenberge, J. (1970), Het begrip arbeidsongeschiktheid in de sociale verzekeringswetgeving van Duitsland, Frankrijk, Nederland en België; historische en rechtsvergelijkende benadering (The work incapacity concept in social insurance legislation of Germany, France, the Netherlands and Belgium; a historical and judicial-comparative approach), Antwerpen.

Van Steenberge, J. (1986), Het arbeidsongeschiktheidsbegrip in evolutie (The evolution of the work incapacity concept), Tijdschrift voor Verzekeringsgeneeskunde, 24, pp. 212-219.

Van 't Hullenaar, R.H.J. \& Van Koningsveld, D.B.J. (1986), Afgebrand of afgedankt; een onderzoek naar oorzaken van arbeidsongeschiktheid (Burnt out or obsolete; an investigation into causes of work incapacity), Swets \& Zeitlinger, Lisse.

Veerman, T.J. (1982), Veelverzuim in het onderwijs (Frequent sickness absence in teachers), Werkgroep Arbeidsvraagstukken en Welzijn, Leiden. 
Veerman, T.J. (1985) Ziekteverzuim en bedreigde werkgelegenheid: enige bevindingen op drie niveaus (Sickness absence and employment uncertainty; some findings on three levels of analysis), Gezondheid en samenleving, 6, pp. 174-181.

Verbaan, D. (1986), De verzuimbenadering bij de Nederlandse Philipsbedrijven. (Sickness absence policy in Dutch Philips firms). In: Steensma, H.O. \& Vrooland, V.Chr., Ziekteverzuimbeleid, werk en gezondheid; 3 voorbeeldprojecten (Sickness absence policy, work and health; three typical projects), CCOZ, Amsterdam, pp. 9-32.

Verband Deutscher Rentenversicherungsträger (1983...1989a), Statistik Rentenzugang (New pension recipients statistic), Frankfurt.

Verband Deutscher Rentenversicherungsträger (1983...1989b), Statistik Rentenbestand (Pension recipients statistic), Frankfurt.

Von Ferber, Chr. (1969), Ergebnisse arbeits- und betriebssoziologischer Untersuchungen zum Krankenstand (Results of sociological research on sickness absence), Die Ortskrankenkasse, 51, pp. 141-146.

Von Ferber, Chr. (1983), Morbiditätsaspekte der Arbeitsunfähigkeit; kurze und lange Arbeitsunfähigkeiten (Morbidity aspects of short and long term work incapacity), Das offentlichte Gesundbeitswesen, 7, pp. 368-373.

Vroege, D. (1982), Ziekteverzuim in Nederland, een bedrijfsgeneeskundige visie (Sickness absence in the Netherlands; an occupational health approach), Bedrijfsgeneeskundige Dienst, Rotterdam.

Vroege, D. (1983), Ziekteverzuim, arbeidsongeschiktheid en sterfte in relatie tot het Nederlandse arbeidsproces. (Sickness absence, invalidity, mortality and the Dutch labour process). Tijdschrift voor Sociale Gezondheidszorg 61, 24, pp. 920-927.

Vrijhof, B.J. (1986), De ontwikkeling van bet verzuim in Nederland (The development of sickness absence in the Netherlands), Stichting $\mathrm{CCOZ}$, Amsterdam.

Vrijhof, B.J. (1987a), Ziekteverzuim 1985-1986 (Sickness absence 1985-1986), Stichting CCOZ, Amsterdam.

Vrijhof, B.J. (1987b), Nulverzuim, een interessant aspect van ziekteverzuim? (The never sick: an interesting aspect of sickness absence?), NIA, Amsterdam.

Vrijhof, B.J. \& Andriessen, S. (1986), Ziekteverzuim 1981-1985 (Sickness absence 1981-1985), Stichting $\mathrm{CCOZ}$, Amsterdam.

Wiersma, D. (1980), Psychosociale stress en langdurige arbeidsongeschiktheid (Psychosocial stress and prolonging work incapacity), Konstapel, Groningen.

Yemin, E. (1982), Workforce reductions in undertakings. International Labour Office, Geneva.

Yin, R.K. (1984), Case study research; design and methods, Sage Publications, Beverly Hills.

Ziekteverzuim van de beroepsbevolking 1981-1984 (1986), (Absence from work 1981-1984), Maandbericht gezondheidsstatistiek, 4, pp. 5-32.

Zimmerman W. (1970), Feblzeiten und industrieller Konflikt; eine organisations-soziologische Untersuchung in einem Hüttenwerk (Work absence and industrial conflict; an organizationsociological investigation in a blast furnace), Ferdinand Enke Verlag, Stuttgart. 
Zimmerman, W. (1978), Krankenstand, Deutsche Verhältnisse (Sickness absence, the German Situation). In: Schäfer,H. \& Blohmke,M., Handbuch der Sozialmedizin, Band III, Ferdinand Enke Verlag, Stuttgart, pp. 120-141. 



\section{TABLES}

Table 1.1 Sickness absence rates in the Netherlands (1964, 1969, 1974, 1979, 1984, 1988).

Table 1.2 Selected statistical comparisons, Belgium, Germany, the Netherlands (1976...1988).

Table 2.1 Overview of international sickness absence rates from various sources, based on macro-statistics (1956...1988)

Table 2.2 International differences in sickness absence based on company figures (1958....1980, adapted)

Table 3 Major dimensions of sickness benefit programmes in Belgium, Germany and the Netherlands

$\begin{array}{lll}\text { Table } 4.1 \quad \text { Overview of population characteristics measured } & 61\end{array}$

Table 5.1 Main characteristics of four clusters (1980) 65

Table 5.3.1 Key figures for Case 1 (1980) 68

Table 5.3.2 Annual sickness absence rates (severity, frequency, average duration) in Case 1 (1980, 1981, 1980 and 1980)

Table 5.3.3 Average annual severity and frequency rates by duration class in Case 1 (1980 and 1981)

Table 5.3.4 Average annual sickness absence rates by sex and occupational states in Case 1 (1980 and 1981)

Table 5.3.5 Average annual severity and frequency rates standardized for sex, age and occupational status in Case 1 (1980 and 1981)

Table 5.4.1 Key figures for Case 2 (1980)

Table 5.4.2 Annual sickness absence rates (severity, frequency, average duration) in Case 2 (1980, 1981, 1980 and 1981)

Table 5.4.3 Average annual severity and frequency rates by duration class in Case 2 (1980 and 1981)

Table 5.4.4 Average annual sickness absence rates by sex and occupational status in Case 2 (1980 and 1981)

Table 5.4.5 Average annual severity and frequency rates standardized for sex, age and occupational status in Case 2 (1980 and 1981) 
Table 5.5.2 Annual sickness absence rates (severity, frequency, average duration) in Case 3 (1980, 1981, 1980 and 1981)

Table 5.5.3 Average annual severity and frequency rates by duration class in Case 3 (1980 and 1981)

Table 5.5.4 Average annual sickness absence rates (severity, frequency, duration) by sex and occupational status in Case 3 (1980 and 1981)

Table 5.5.5 Average annual severity and frequency rates standardized for sex, age and occupational status in Case 3 (1980 and 1981)

Table 5.6.1 Key figures for Case 4 (1980)

Table 5.6.2 Annual sickness absence rates (severity, frequency, average duration) in Case 4 (1980, 1981, 1980 and 1981)

Table 5.6.3 Average annual severity and frequency rates by duration class in Case 4 (1980 and 1981)

Table 5.6.4 Average annual sickness absence rates (severity, frequency, duration) by sex and occupational status in Case 4 (1980 and 1981)

Table 5.6.5 Average annual severity and frequency rates standardized for sex, age and occupational status in Case 4 (1980 and 1981)

Table 6.1 Overview of indexed sickness absence rates in four clusters (1980 and 1981).

Table 6.2 Average annual severity and frequency rates by duration class in the Belgian, German and Dutch group (1980 and 1981).

Table 6.3 Key figures for aggregated cases (three national groups) (1980)

Table 6.4 Average annual sickness absence rates by sex and occupational status in three national groups (1980 and 1981)

Table 6.5 Overview of indices for severity and frequency rates in four case studies after direct standardization (1980 and 1981)

Table 6.6 Average annual severity and frequency rates standardized for sex, age and occupational status in three national groups (1980 and 1981)

Table 6.7 Frequency distribution of sickness absence in three national groups (average 1980 and 1981)

Table 6.8 Relative distribution of absence rates by duration class in three national groups (1980 and 1981)

Table 6.9 Summary of observed sickness absence differences

Table 7.1 Major categories of sickness absence factors investigated in Belgium, Germany and the Netherlands

Table 7.2 Overview of data collection methods applied 
Table 8.1 Relative age distribution and severity rates by sex and age in the Belgium and Dutch group $(1980,1981)$

Table 8.2 Average annual sickness absence rates by duration class for native (Nat) and migrant (Mig) employees in three national groups (1980 and 1981)

Table 8.3 Average annual severity and frequency rates by occupational status and duration class in three national groups (1980 and 1981)

Table 8.4 Relatively high and low risk categories regarding sickness absence frequency in three national groups (1980)

Table 8.5 Relatively high and low risk categories regarding sickness absence severity in three national groups (1980)

Table 8.6 Partial and multiple correlations of (rescaled) variables to frequency and severity rates in three national groups 1980 (1981)

Table 8.7 Overview of F-values in analysis of co-variance on three national groups $(1980,1981)$

Table 8.8 Adjusted sickness absence rates in three national groups $(1980,1981)$

Table 9.1 Average annual number of days off in three national groups $(1980,1981)$

Table 9.2 Sickness absence rates in leavers in two national groups (1980 and 1981) 156

Table 10.1 Some dimensions of invalidity pension programmes in Belgium, Germany and the Netherlands.

Table 10.2 Reported causes of invalidity benefits completion in Belgium, Germany and the Netherlands (1983-1987)

Table 10.3 Selected classic health measures in Belgium, Germany and the Netherlands

Table 10.4 Selected health behaviour indicators for Belgium, Germany, the Netherlands

Table 11.1 Overview of frequency reducing factors in Belgium, Germany and the Netherlands

Table 11.2 Overview of major absence duration factors in Belgium, Germany and the Netherlands 


\section{FIGURES}

Figure 5.3.1 Average age-specific severity and frequency rates in Case 1 (1980 and 1981)

Figure 5.4.1 Average age-specific severity and frequency rates in Case 2 (1980-and 1981)

Figure 5.5.1 Average age-specific severity and frequency rates in Case 3 (1980 and 1981)

Figure 5.6.1 Average age-specific severity and frequency rates in Case 4 (1980 and 1981)

Figure 6.1 Age-specific frequency and severity rates in three national groups (1980 and 1981)

Figure 6.2 Frequency rates by month for three national groups $(1980,1981)$

Figure 6.3 Relative distribution of absence frequencies over a two-year period in three national groups (1980 and 1981)

Figure 6.4 Annual mean frequency of spells by length (1-15 days) in three national groups (1980 and 1981)

Figure 6.5 Mean annual number of spells per 1000 persons by length, 1-13 weeks, (1980 and 1981), logarithmic transformation

Figure 6.6 Average annual number of spells lasting over 13 weeks per 1000 persons by duration class in three national groups (1980 and 1981)

Figure 6.7 Cumulative percentage of persons with an absence lasting 13-52+ weeks by week of termination in three national groups (1980 and 1981)

Figure 6.8 Sickness absence in Belgian, German and Dutch insured 1970-1987 (severity ratios: $1970=100$ )

Figure 6.9 Estimated sickness absence percentages in Belgian, German and Dutch insured, standardized to age and sex (1983-1987)

Figure 6.10 Number of spells lasting over six weeks per 1000 insured in Belgium, Germany and the Netherlands (1983-1987)

Figure 7.1 A micro-model of sickness absence behaviour

Figure 7.2 An integrated model of sickness absence

Figure 8.1 Average annual short and long term frequency rates by age in three national groups (1980 and 1981) 
Figure 8.2 Average annual sickness absence rates by length of service in three national groups (1980 en 1981)

Figure 8.3 Average annual sickness absence rates by shift type in three national groups (1980 and 1981)

Figure 9.1 Average yearly severity and frequency rates in entrants, stayers and leavers (1980 and 1981)

Figure 10.1 Number of invalidity pension recipients per 1000 insured in Belgium, Germany and the Netherlands at 31.12 (1970-1987).

Figure 10.2 Average yearly number of new invalidity benefit recipients per 1000 insured by age group in Belgium, Germany and the Netherlands (1980 - 1987).

Figure 10.3 Standardized invalidity incidence rates in Belgian, German and Dutch insured (1980-1987)

Figure 10.4 Main diagnostic of groups new invalidity benefit recipients per 10.000 insured (1980-1987) in Belgium, Germany and the Netherlands

Figure 10.5 Average yearly number of terminations per 1000 invalidity benefits recipients by age-group in Belgium, Germany and the Netherlands (1983-1987)

Figure 10.6 Mortality rates in Belgian, German and Dutch invalidity benefit recipients aged under $65(1983-1987)$ 



\section{CURRICULUM VITAE}

De auteur werd op 8 januari 1949 te Dokkum geboren. Na het behalen van het H.B.S.-A diploma studeerde hij Westerse Sociologie (specialisatie: Methoden \& Technieken) aan de Vrije Universiteit te Amsterdam. Na als socioloog zijn militaire dienstplicht te hebben vervuld bij de Sociaal-Psychiatrische Dienst (KL), trad hij in maart 1976 in dienst bij de voormalige Stichting CCOZ. Hij was gedurende vier jaar projectleider van een ziekteverzuimregistratieproject en verrichtte onderzoek naar de beleids- en onderzoeksmatige benutting van ziekteverzuim- en bedrijfsongevallencijfers. Sinds 1983 houdt hij zich met name bezig met (ten dele internationaal-vergelijkend) onderzoek rond ziekteverzuim, arbeidsongeschiktheid, arbeidsomstandigheden en gezondheidsindicatoren. Thans is hij programmaleider voor onderzoek op het terrein van ziekte, arbeidsongeschiktheid en sociale zekerheid bij het Nederlands Instituut voor Arbeidsomstandigheden (NIA) te Amsterdam. Hij publiceerde over de bovengenoemde thema's in Nederlandse en buitenlandse vaktijdschriften en trad in Nederland en België op als docent voor bedrijfsartsen en verzekeringsgeneeskundigen. 